IVANDRO RISTUM TREVELIM

\title{
A POSSE NA REGULARIZAÇÃo DE ASSENTAMENTOS URBANOS
}

DOUTORADO EM DIREITO

ORIENTADOR: PROFESSOR DOUTOR ÁLVARO VILLAÇA AZEVEDO

FACULDADE DE DIREITO

DA UNIVERSIDADE DE SÃO PAULO 


\title{
A POSSE NA REGULARIZAÇÃO DE ASSENTAMENTOS URBANOS
}

\author{
Tese apresentada à banca examinadora da \\ Faculdade de Direito da Universidade de São \\ Paulo, como exigência parcial para obtenção \\ do título de Doutor em Direito (Direito \\ Civil), sob a orientação do Professor Doutor \\ Álvaro Villaça Azevedo.
}

\section{SÃO PAULO}


Banca Examinadora 
À memória de meu pai,

João Luiz Trevelim. 
Agradecimentos

Ao Professor

Álvaro Villaça Azevedo, pelas inestimáveis lições de Direito Civil e de vida. 


\section{RESUMO}

A nova disciplina legal da posse como direito real no âmbito da regularização fundiária no Brasil coloca-se como importante mecanismo para a redução das desigualdades sociais. Será desenvolvido o conceito de posse e seus contornos atuais, especialmente em vista da situação social brasileira, notadamente em função da regularização fundiária no Brasil e a nova disciplina da posse conferida pela Lei $\mathrm{n}^{\circ} 11.977 / 2009$, tal como alterada pela Lei $\mathrm{n}^{\circ}$ $12.424 / 2011$.

Foi esta lei recente que trouxe em seu condão a possibilidade da regularização fundiária de assentamentos urbanos. A ideia de possibilitar esta regularização não é nova - na verdade, já constava do Projeto de Lei $\mathrm{n}^{\mathrm{o}} 3.057$, que tramitava no Congresso Nacional desde o ano 2000 .

A Lei $n^{\circ} 11.977 / 2009$ insere em nosso ordenamento jurídico a regularização fundiária de assentamentos urbanos, consistente no conjunto de medidas jurídicas, urbanísticas, ambientais e sociais objetivando a regularização de assentamentos irregulares e a titulação de seus ocupantes.

Estabelece a competência municipal para dispor sobre o procedimento de regularização fundiária, nos termos da demarcação urbanística. A demarcação urbanística ocorrerá mediante procedimento administrativo pelo qual o Poder Público, no âmbito da regularização fundiária de interesse social, demarca um imóvel de domínio público ou privado, definindo seus limites, sua área, sua localização e seus confrontantes, com a finalidade de identificar seus ocupantes e qualificar a natureza e o tempo das respectivas posses.

É nesse contexto que ocorrerá inicialmente a legitimação de posse ao ocupante do imóvel objeto da demarcação urbanística, uma vez que o Poder Público deverá proferir ato administrativo capaz de conferir título de reconhecimento de posse do imóvel, com a identificação deste ocupante, do tempo e da natureza da posse. 
Se bem sucedida a demarcação urbanística, a partir da averbação do auto de demarcação urbanística, o Poder Público deverá elaborar o Projeto de Regularização Fundiária e submeter o parcelamento dele decorrente a registro.

Após o registro do parcelamento, o Poder Público concederá título de legitimação de posse aos ocupantes cadastrados (preferencialmente em nome da mulher). A legitimação de posse devidamente registrada constitui direito a favor do detentor da posse direta para fins de moradia, desde que não seja proprietário ou detentor de posse de outro imóvel.

Sem prejuízo dos direitos decorrentes da posse exercida anteriormente, o detentor do título de legitimação de posse, após cinco anos de seu registro, poderá requerer ao oficial de registro de imóveis a conversão desse título em registro de propriedade, tendo em vista sua aquisição por usucapião - instituindo modalidade de usucapião administrativo.

Diante do exposto, percebe-se que a referida Lei $\mathrm{n}^{\circ} 11.977 / 2009$ trouxe em seu bojo tema de grande interesse, conferindo uma conotação e fortalecimento legal até então inédita à posse: a posse como direito real. Este tema merece estudo aprofundado; é o que se propõe com o presente trabalho. 


\section{ABSTRACT}

The new legal regulation of possession as a real estate right in the land title regularization procedure is an important mechanism to reduce the social and economic discrepancies in Brazil. The concept of possession according to Brazilian law will be develop and its current highlights, notably vis-à-vis the Brazilian social background in land and title regularization processes and the new regulation issued by Law No. 11,977/2009, as modified by Law No. 12,424/2011.

These laws recently brought the possibility to carry out the title and land regularization to Brazilian urban settlements (assentamentos urbanos). Then idea of regularizing such settlements is not completely new, once was already part of a quite old bill, No. 3,057, already being discussed in National Congress since the year of 2000.

Law No. 11,977/2009 launches in the Brazilian legal system the Land and Title Regularization Program form Urban Settlements, comprising in some legal, urban related, environmental and social measures towards the regularization of title and land over urban settlements that did not comply with regulation, also providing the occupiers with title to their plots of land.

It also establishes the municipal legal responsibility to provide for the rules necessary to establish the land and title regularization procedures, according to the Urbanistic Meets and Bounds (Demarcação Urbanística). The Urbanistic Meets and Bounds will take place by means of an administrative procedure, in which the local Government provides for the meets and bounds of a specific area (public or privately held), indication its actually meets, bounds, description, location, seeking to also identify its occupants and to qualify the time and nature of their possession over the land.

In this context the legitimation of possession will be granted to such occupiers, considering the local Government must issue the administrative acknowledgement of such possessions, identifying its possessor and the time such fact took place. 
Once successfully established the Urbanistic Meets and Bounds, the Government will also develop the regularization project and provided for the land parceling according to the occupation found therein.

After registering the land parceling, the legitimation of possession issued by the Government (to be given preference to women) will be register with the Real Estate Registry Office, creating right to the occupier for effects of housing, provided that he or she is not owner of any other property.

After five years, the occupier may request to the Real Estate Registry Office that the legitimation of possession be automatically conveyed into ownership, due to the adverse possession (usucapião) - creating also a new mechanism of administrative acquisition.

Accordingly, one could notice that said Law No. 11.977/09 brings attention to a subject of great importance and extremely interesting, granting such a legal power to possession that was not yet seen in the Brazilian legal system: possession as a real estate right. This matter deserves to be thoroughly reviewed, and that is the challenge accepted in this work. 


\section{RÉSUMÉ}

Le nouvel encadrement juridique de la possession comme droit réel vis-à-vis la régularisation foncière au Brésil apparaît comme un important mécanisme de réduction des inégalités sociales. La notion de possession et ses contours actuels seront étudiés dans ce travail, spécialement au regard de la situation sociale brésilienne, et notamment en raison de la régularisation foncière au Brésil et le nouvel encadrement de la possession accordée par la Loi n $11.977 / 2009$, modifiée par la loi n $12.424 / 2011$.

Cette récente loi a permis régularisation foncière des établissements urbains. L'idée de permettre cette régularisation n'est pas nouvelle. En fait, elle était déjà prévue dans un projet de loi plutôt vieux, le projet $n^{\circ} 3.057$, qui était examiné par le Congrès dès l'année 2000.

La Loi $\mathrm{n}^{\circ}$ 11.977/09 introduit, dans notre système juridique, la régularisation foncière des établissements urbains, c'est à dire, l'ensemble des mesures juridiques, urbaines, environnementales et sociales visant à la régularisation des établissements informels et à la délivrance des titres à ses occupants.

Les municipalités locales ont compétence de se prononcer sur la procédure de régularisation foncière, selon la démarcation urbaine. La démarcation urbaine est faite par le biais d'une procédure administrative, par laquelle le Gouvernement, en vue de la régularisation foncière d'intérêt social, détermine un immeuble comme de domaine public ou privé, fixant ses limites, sa superficie, sa localisation et sa voisinage, dans le but d'identifier ses occupants et de qualifier la nature et le temps de chaque possession.

C'est dans ce contexte que se produira, initialement, la légitimation de la possession de l'occupant de l'immeuble qui fait l'objet de la démarcation urbaine; puisque le Gouvernement doit publier un acte administratif susceptible de conférer à cet occupant le titre de reconnaissance de la possession de l'immeuble, avec son identification, et l'indication du temps et de la nature de sa possession. 
En cas de succès de la démarcation urbaine, à partir de l'enregistrement de l'acte de démarcation urbaine, le Gouvernement doit élaborer le projet de régularisation foncière et inscrire ses divisions au registre foncier.

Après l'enregistrement des divisions, le Gouvernement fournit le titre de légitimation de la possession aux occupants inscrits (de préférence aux femmes). La légitimation de la possession dûment enregistrée est un droit en faveur du détenteur de la possession directe des logements, à condition que cet occupant ne soit pas propriétaire ou détenteur de possession d'un autre immeuble.

Nonobstant les droits dérivés de la possession exercée précédemment, le détenteur d'un titre de légitimation de possession, après cinq ans de son enregistrement, peut demander à l'agent du Bureau d'Enregistrement d'Immeubles la conversion de son titre en titre de propriété, vu son acquisition par usucapion - ainsi créant la modalité d'usucapion administrative.

Compte tenu des considérations exposées ci-dessus, la Loi n 11.977/2009 a apporté un thème de grand intérêt, en donnant à la possession une connotation et un renforcement juridique inédites: la possession comme un droit réel. Ce sujet mérite une étude approfondie et de qualité, ce qui est proposé dans ce travail. 


\section{SUMÁRIO}

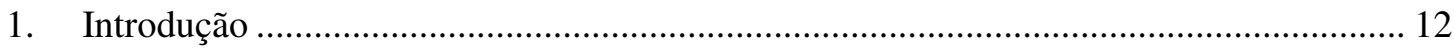

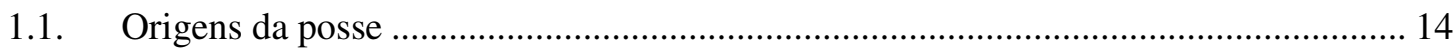

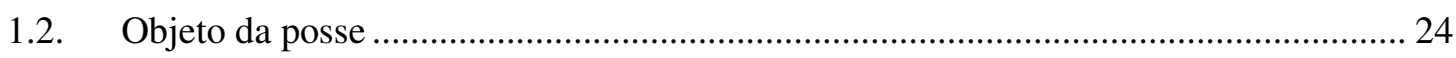

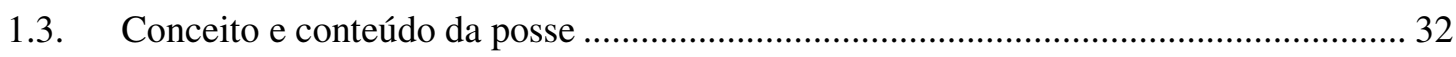

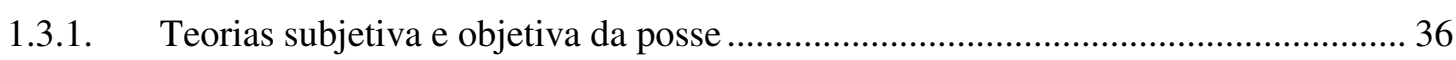

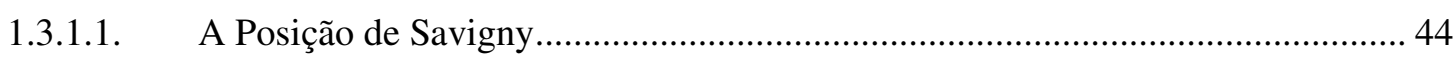

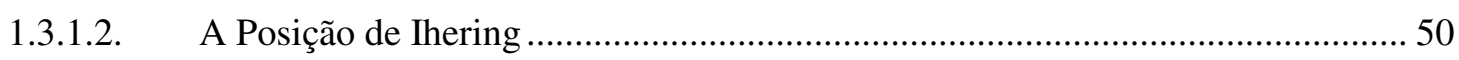

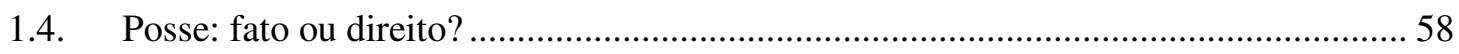

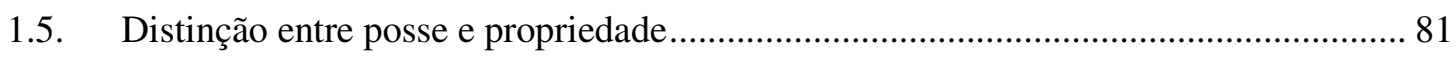

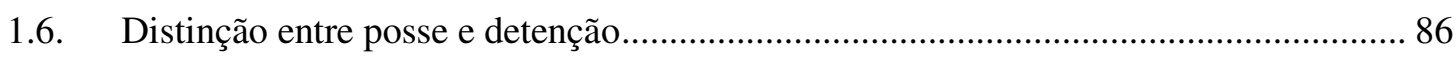

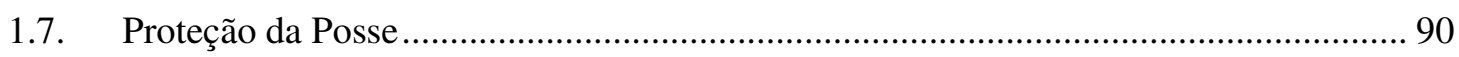

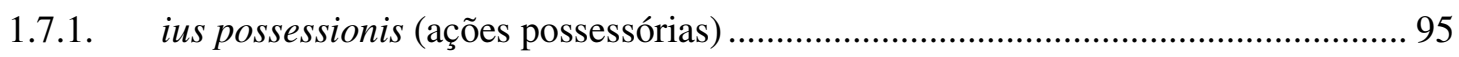

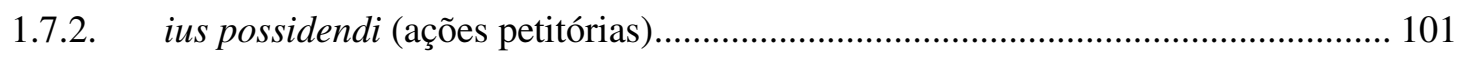

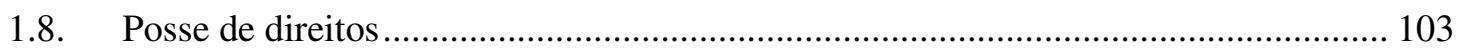

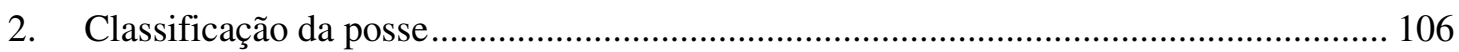

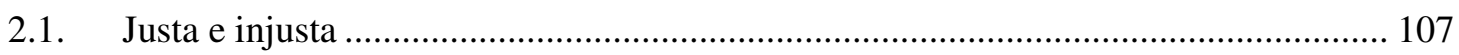

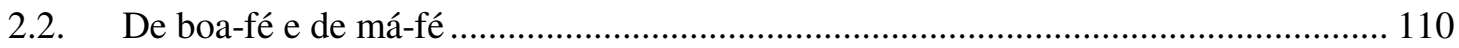

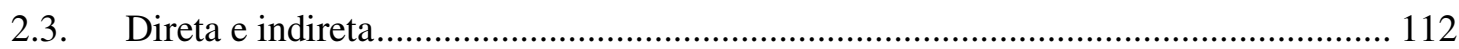

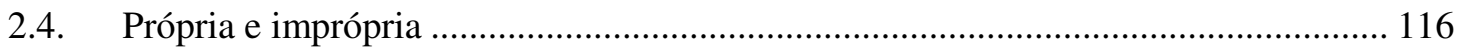

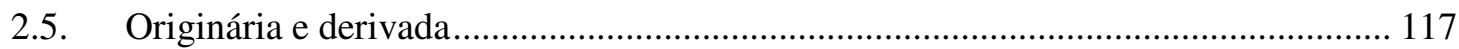

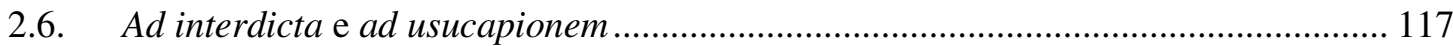

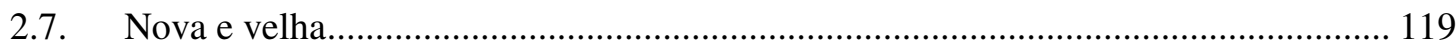

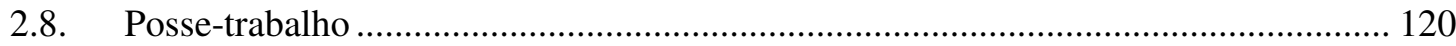

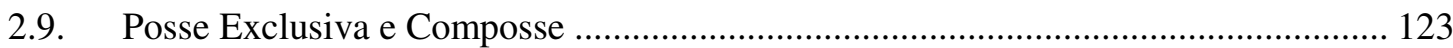

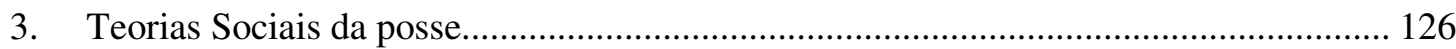

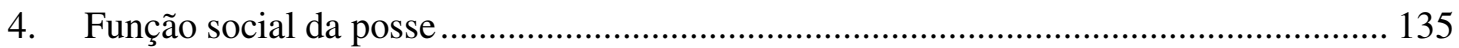

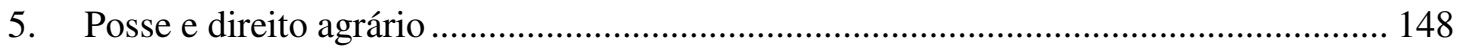

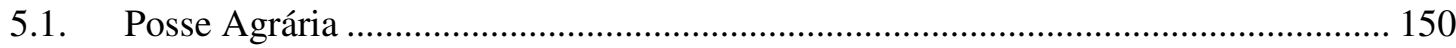

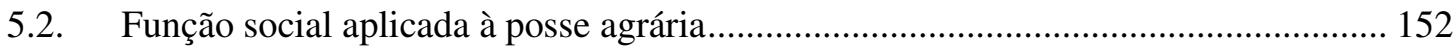

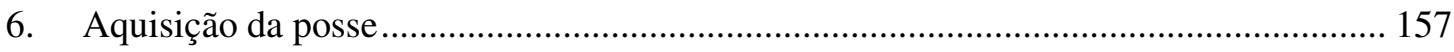

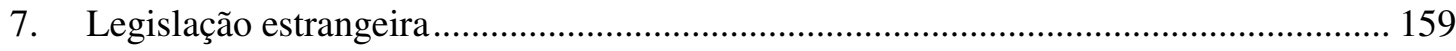

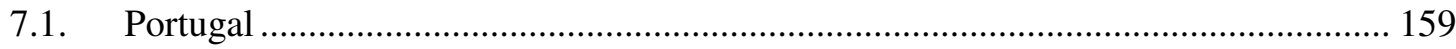




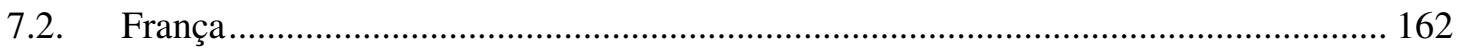

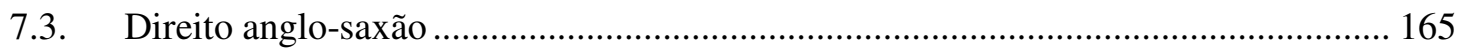

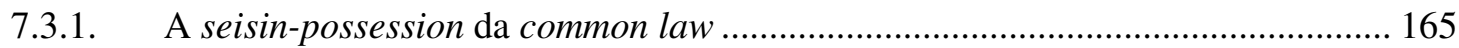

7.3.2. Conceito de posse na common law..................................................................... 168

7.4. O Registro da Posse na Legislação Estrangeira ........................................................ 173

8. A questão da ocupação de imóveis rurais por estrangeiros.............................................. 179

8.1. Retrospecto legal e mudança do marco regulatório ....................................................... 180

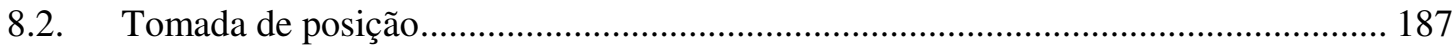

9. Nova disciplina da posse conferida pela Lei $\mathrm{n}^{\circ}$ 11.977/2009......................................... 190

9.1. O registro da Posse no âmbito da Regularização Fundiária de Interesse Social ........ 191

9.2. Procedimento da regularização: a demarcação urbanística.......................................... 199

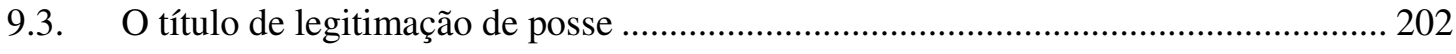

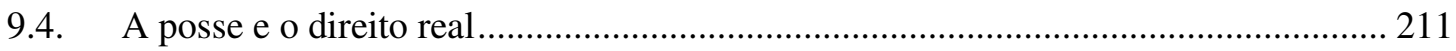

9.5. A regularização fundiária no Brasil - Casos Práticos Pesquisados ............................. 215

9.6. Anexos - Registro da Posse na matrícula do imóvel .................................................... 218

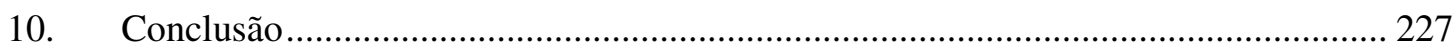

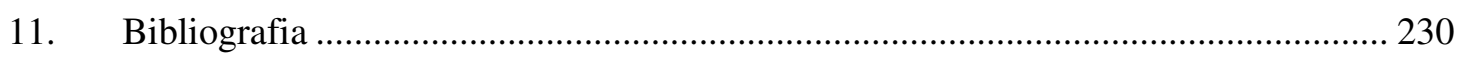




\section{INTRODUÇÃO}

Tratando-se de posse, estamos no campo do provável e da aparência. Apesar de ser um estado de aparência, continua a ser protegida. Há muito tempo é defendida e resguardada primeiro a aparência representada na posse, para depois se averiguar com mais vagar a existência de outros direitos subjacentes. Trata-se da proteção de direitos prováveis: "defende-se a posse porque é uma situação de fato que provavelmente envolve um direito"1.

Já mencionava Silvio Rodrigues que, como a posse pode encobrir uma situação de direito, o legislador a protege, até que pelas vias ordinárias se evidencie o contrário. Isso porque, de qualquer forma, a condição de possuidor é melhor que a do estranho, e aquele deve ser protegido contra este ${ }^{2}$.

Ademais, reforçando o estado de aparência acima mencionado, a posse aparece como exteriorização do domínio, a maneira pela qual aquele que exerce um poder sobre o bem manifesta que tal bem está sendo empregado para seu fim econômico. Apenas quem detém a posse pode usufruir economicamente do bem. Não sem motivo, Ihering defendia que a propriedade dissociada da posse equivaleria a um baú de tesouro desprovido da chave.

Em nome da harmonia social, é defendida a situação aparente, a primeira forma na qual a posse se manifesta. Nesse sentido, lapidar é a colocação do jurista português Ascensão: "A posse é uma das grandes manifestações no mundo do direito do fenômeno social da inércia. Em princípio, não se muda nada. Deixa-se tudo continuar como está, para evitar o desgaste de uma mudança. (...) Quando alguém exerce poderes sobre uma coisa, exteriorizando a titularidade de um direito, a ordem jurídica permite-lhe, por esse simples fato, que continue a exercer, sem exigir maior justificação"3.

Isso porque, para a consolidação da paz social, apenas a estabilização da situação fundada na aparência do direito basta, em um primeiro momento.

\footnotetext{
${ }^{1}$ Silvio de Salvo Venosa. Código Civil Comentado Vol. XII, p. 27.

${ }^{2}$ Silvio Rodrigues. Direito das Coisas, p. 17.

${ }^{3}$ José de Oliveira Ascensão. Direito das Coisas - reais, p. 73.
} 
Não é tarefa fácil conceituar e definir a posse, especialmente em razão da relatividade que ela apresenta - muitas vezes uma pessoa pode entender que detém a posse de um bem quando, na verdade, isso não acontece. Podemos usar uma situação descrita pelo grande teórico da posse, Ihering, para explicitar tal dificuldade: alguém que encontra uma cigarreira na estrada, ao alcançá-la, não estará atentando contra a posse de outro, podendo ser considerado seu novo possuidor, uma vez que, evidentemente, tal cigarreira foi inadvertidamente perdida, certo de que a situação na qual ela se encontra não condiz com a sua normal utilização econômica.

Segundo Ihering, aquele que permanecer com a cigarreira não estará infringindo nenhuma norma jurídica. Mas se utilizarmos o mesmo exemplo e substituirmos a cigarreira por uma barra de ouro, esta barra também estará fora de sua situação normal de uso, por estar no meio de uma estrada; aquele que a encontrar, à exemplo da cigarreira, também poderia permanecer com a barra de ouro, sem infringir nenhuma norma jurídica? Faria mais sentido ele se sentir o novo possuidor ou buscar aquele que a deteve anteriormente? Percebemos que não se está diante de tarefa simples captar os sinais distintivos da posse.

Roberto de Ruggiero também expressa a grande dificuldade envolvendo o instituto da posse ao mencionar que foi "o conceito sobre o qual mais se cansaram as mentalidades dos juristas", pois abstratamente envolve "um conjunto mais ou menos amplo de situações de fato protegidas ou consideradas de modo diverso pelo direito objetivo", impactando e criando, desta forma, "oscilações" tanto nas formulações dos juristas ao longo do tempo quanto dos vários direitos. Assim, seria vão "procurar-se um ponto fixo de partida, comum às várias concepções teóricas do instituto no próprio direito romano e no nosso" 4 . Para Ruggiero, tudo começa com um estado de fato, pelo qual uma pessoa tem em seu poder uma coisa, isto é, "detêm-se na sua guarda, ou para seu uso, com ou sem ânimo de a ter como própria".

Lembra Moreira Alves que "o estudo das alterações introduzidas nos textos clássicos permitiu a demonstração que o direito romano, não conheceu, em todo seu curso,

\footnotetext{
${ }^{4}$ Roberto de Ruggiero. Instituições de Direito Civil. Vol. II, p. 738-739.
} 
concepção unitária da posse (...), mas ao contrário, apresentava diferenças profundas nas diversas épocas de sua evolução" 5 .

Outro problema a ser enfrentando será constatar se a posse é um fato apenas, um direito, ou ambos. E entraremos no cerne da grande discussão: sendo um direito, seria um direito real? Faria sentido social, em sociedades como a nossa, que ainda precisam imensamente instrumentalizar esse instituto, considerá-la como um direito real, de forma a obter o benefício de todas as prerrogativas e qualidades que tais direitos apresentam?

O presente trabalho buscar superar toda a dificuldade terminológica (que também variou muito no decorrer dos séculos) e conceitual, para extrair da posse aquilo que nos interessa nos dias de hoje, especialmente em nosso país, que busca atualmente um maior desenvolvimento econômico e social e superar seu déficit habitacional.

A posse vem ganhando importância no Brasil, pois ainda temos muito a regularizar em termos de assentamentos em áreas urbanas, conferindo titulação àqueles que ainda não a detém, nem deteriam de outra forma se fossem mantidas ou aplicadas as regras urbanísticas tradicionais. E a importância, tratando-se da posse, em razão desse passivo, só tende a crescer nos próximos anos.

Por outro lado, percebe-se que em países já desenvolvidos como Inglaterra, Alemanha, Espanha e Portugal, a situação possessória perde importância, a ponto de a legislação tornar mais dificultosos os processos fundamentados na posse, como a usucapião, o que veremos no decorrer do trabalho.

Assim, percebemos que a importância da posse em um dado meio jurídico é proporcional ao passivo de regularização fundiária existente.

\subsection{ORIGENS DA POSSE}

\footnotetext{
${ }^{5}$ José Carlos Moreira Alves. Posse, V. I. Evolução Histórica, p. 7.
} 
Também não é clara e desprovida de incerteza a origem etimológica do termo posse, divergindo a doutrina a respeito.

No ensinamento de Biondo Biondi, a noção geral e mais abrangente de possessio é aquela de domínio sobre a coisa corporal. Este conceito está inserido na própria palavra possidere, que vem de potis sedeo, isto é, sento, sou senhor. Enquanto o dominium é um poder jurídico, e como tal tutelado pela lei romana, a possessio é uma autoridade de fato, protegida pela lei contra determinadas lesões. A propriedade era claramente distinta da posse, pois, afirmavam já os romanos: separata esse debet possessio a proprietate (D. 43, 17, 1, 2); nihil commune habet proprietas cum possessione (D. 41, 2, 12, 1$)^{6}$.

O termo posse poderia ter também origem no latim, em possessio, de sedere, estar sentado, com o prefixo pos, que reforça o sentido - sendo um conceito jurídico cuja aparente simplicidade conceitual resulta de enorme complexidade, conforme o ensinamento de Pedro Henrique de Miranda Rosa ${ }^{7}$.

No tocante à etimologia da palavra posse, indica Serpa Lopes que quer se origine da palavra sedibus, quer mais expressamente de a pedibus, "traduz esse poder material físico do homem sobre a coisa" ${ }^{\circ}$.

Ebert Chamoun indica que possessio provém de potis, radical de potestas (poder), e sessio de mesma origem de sedere (estar assente) - indicando um "poder que se prende a uma coisa". Lembra que a posse sofre evolução no decorrer da história do Direito romano, originando-se no mundo fático ("nas origens era a posse o exercício de uma senhoria, quer sobre a terra (...), depois da constituição da cidade, sobre o ager publicus, (...) quer, mais tarde ainda, sobre o solo provincial"), e passando ao mundo do direito: "A posse não é mais uma senhoria de fato, mas um direito, visto que, então, só possui quem tem direito a possuir" 9 .

\footnotetext{
${ }^{6}$ Biondi Biondo. Istituzioni di Diritto Romano, p. 323.

${ }^{7}$ Pedro Henrique de Miranda Rosa. Fontes Históricas da Teoria da Posse no Direito Civil Brasileiro, p. 13.

${ }^{8}$ Miguel Maria de Serpa Lopes. Curso de Direito Civil. Direito das coisas. Vol. VI, p. 85.

${ }^{9}$ Ebert Chamoun. Instituições de Direito Romano, p. 218-219.
} 
Para Silvio de Salvo Venosa, "na concepção mais aceita, o vocábulo posse provém de possidere; ao verbo sedere apõe-se o prefixo enfático por. Nesse sentido (semântico), prende-se ao poder físico de alguém sobre a coisa. Há também os que sustentam que o termo deriva de potis (senhor, amo)"10 11.

Edmundo Pereira Lins ensina que a origem etimológica mais prestigiada é a composição de pos anteposto a sedere e sessio, podendo pos ser um prefixo de reforço acentuando vigor ou insistência com o ato expresso pela palavra a que se junta, ou ainda uma preposição de lugar (junto de, perto de, ao lado de). No ensinamento do antigo ministro e presidente da então denominada Corte Suprema dos Estados Unidos do Brasil, Edmundo Pereira Lins, a noção de posse: relação de fato entre uma pessoa e uma coisa, "de modo a poder utilizar-se da mesma, tê-la debaixo dos pés (pedum positio) ou do assento (sedium positio), exercer um poder sobre ela (posse), conservá-la junto ou perto de si (pos sedere $)^{, 12}$.

Castan Tobeñas apresenta também a origem etimológica das palavras possidere e possesio derivando do verbo sedere (sentar-se, estar sentado) e do prefixo pos, que traz reforço, significando estabelecer-se ou estar estabelecido, devendo pos originar-se de pot (pos-sum, potens), que traz consigo a ideia de $\operatorname{poder}^{13}$.

Explica Castan Tobeñas que há três aspectos que constituem o conceito científico de posse: (a) a posse implica uma relação do homem com as coisas; (b) essa relação é de poder ou dominação; e (c) esse domínio é de fato, efetivo, sem entrar no mérito se traz consigo ou não a titularidade de domínio. Na concepção romanística, há também a exigência de certo elemento da vontade ou intenção (animus possidendi ou animus domini) para distinguir a posse em sentido jurídico da simples detenção material.

\footnotetext{
${ }^{10}$ Silvio de Salvo Venosa. Código Civil Comentado Vol. XII - Coordenador Álvaro Villaça Azevedo, p. 22.

${ }^{11}$ Idem. Direitos Reais, p. 30.

${ }^{12}$ Edmundo Pereira Lins. Estudos Jurídicos na Cátedra e na Judicatura. Ensaio sobre a Posse (direito romano e civil), p. 116.

${ }^{13}$ Da mesma forma, no alemão, a origem etimológica das palavras betizen (possuir) e besitz (posse) derivam de sitzen (sentar-se ou estar sentado) e do prefixo be, que dá reforço. Jose Castan Tobeñas. Derecho Civil Español, Comun y Foral, p. 639-640.
} 
Por isso, o aspecto problemático é definir algo que esteve em constante evolução, acertar um alvo em movimento, levando em consideração constantes modificações sofridas ao longo do tempo (o que acontece até os dias de hoje) - sendo a posse uma "possibilidade de exercício da senhoria sobre uma coisa, protegida juridicamente", fundando-se "no direito clássico, na intenção de ter a coisa como se fosse própria (animus possidendi) e, no direito justinianeo, no desejo de ser proprietário (animus domini, opinio domini). São dois, portanto, os elementos da posse: um elemento material, consistente na relação com a coisa, que possibilita o exercício da senhoria e que se costuma designar com o termo corpus, e um elemento psíquico que era, no direito clássico, a intenção de possuir ou de ter a coisa como se fosse própria, intitulada animus possidendi, e no direito jutinianeo, o desejo de ser proprietário ou de se transformar em dono da coisa, chamada animus domini" ${ }^{14}$

Indica Ruggiero que a origem terminológica da posse estaria na palavra possidere, que para os romanos significava ter a coisa em seu poder físico ou, ainda, ter poder de fato sobre a coisa, possibilitando dispor dela em todas as suas dimensões, com a exclusão de todos os demais, estando presente a intenção duradoura de tal relação, significando assim a possessio um senhorio ou domínio de fato, independente do direito. Por isso, indica Ruggiero que a origem etimológica estaria em pote ou potissedes ${ }^{15}$.

Como aspecto histórico, indica Senise Lisboa, seguindo Ruggiero, que a posse antecede a propriedade por ser poder de fato, originado nos vocábulos potis ou pote, provenientes de potestas; assim, "adquirir a posse não é outra coisa senão começar a possuir (ato de exteriorização da posse)" ${ }^{\prime 16}$.

Caio Mario faz uma interessante digressão sobre a origem etimológica das palavras possessio e possidere, das quais surgiram posse e possuir. A primeira corrente indica pedes ponere (de fixar-se, por os pés). A segunda prega que se originam de sedes ponere, sedium positio, referindo-se à posição do assento. A terceira, mais simplista, indica a origem em posse, poder. A quarta explica a junção das expressões sedere e sessio (assentar-se) às partículas pot ou pos, que conferem ênfase e reforço. Assim, decorre que na posse "está

\footnotetext{
${ }^{14}$ Ebert Chamoun. Instituições de Direito Romano, p. 220.

${ }^{15}$ Roberto de Ruggiero. Instituições de Direito Civil. Vol. II, p. 741.

${ }^{16}$ Roberto Senise Lisboa. Manual de Direito Civil, p. 58.
} 
sempre em foco a ideia de uma situação de fato, em que uma pessoa, independentemente de ser ou de não ser proprietária, exerce sobre uma coisa poderes ostensivos, conservandoa e defendendo-a" 17 .

Com relação ao Direito germânico, indica Martin Wolff que o conceito atual da posse provém de uma combinação de princípios do Direito romano e do Direito germânico. Daí se origina o conceito de gewere (besittinge) com origem no Direito medieval alemão correspondente ao fato da posse do Direito moderno, um puro senhorio de fato sobre a coisa - não distinguindo o Direito alemão a posse jurídica da detenção, pois "também tem gewere aquele que carece do animus dominantis. Também era empregada a palavra gewere (tal como hoje é usada a palavra posse), no sentido de conjunto dos direitos derivados do senhorio sobre uma coisa" ${ }^{\prime 18}$.

Ainda sobre o Direito germânico, Jose Castan Tobeñas indica que a posse correspondia à gewere, conceito que na Idade Média abrangia não só a posse, mas também o direito de propriedade e os demais direitos sobre as coisas, com o significado de investidura ou vestidura, indicando a relação do homem com a coisa, que, por força do ordenamento jurídico, é reconhecida como forma aparente de um senhorio legítimo sobre a coisa ${ }^{19}$.

Valdecasas também ensina que a gewere do Direito germânico corresponde à posse romana, pois também é um poder de fato sobre uma coisa, que transparece como a exteriorização de um direito ou como a manifestação de um senhorio jurídico sobre a coisa. A gewere é, pois, a forma exterior, a vestidura de um direito real. Mas também se diferencia da posse romana, especialmente por apresentar maior extensão, abarcando todo o sistema dos direitos reais ${ }^{20}$.

\footnotetext{
${ }^{17}$ Caio Mario da Silva Pereira. Instituições de Direito Civil - direitos reais, v. IV, p. 11-12.

${ }^{18}$ Martin Wolff. Tratado de Derecho Civil, Tomo Terceiro - Derecho de Cosas, V. I, p. 22.

${ }^{19}$ Da mesma forma, no alemão, a origem etimológica das palavras betizen (possuir) e besitz (posse) derivam de sitzen (sentar-se ou estar sentado) e do prefixo be, que dá reforço. Jose Castan Tobeñas. Derecho Civil Español, Comun y Foral, p. 645.

${ }^{20}$ Guillermo G. Valdecasas. La posesión, p. 5.
} 
Para Senise Lisboa, complementando, a gewere germânica consistia na "publicidade da aparência do poder exercido sobre uma coisa, através da investidura publica", e somente a partir do século XVI a gewere foi equiparada à posse romana ${ }^{21}$.

Pedro Henrique de Miranda Rosa define posse como o "exercício de fato de um direito sobre uma coisa independentemente de que esse direito seja ou não titular de quem o exercer”. Assim, o exercício do direito constitui a posse, atribuindo a lei a esse exercício efeitos e consequências (transformando o estado de fato em situação jurídica). Ocorre também a abstração do fenômeno da posse, passando de "concepção primitiva (ocupação material da coisa), à concepção clássica (ocupação da coisa como se fosse dono), até a admissão de posse do direito (como se fosse titular)",22. Continua referido autor que "a possessio era, pois, um senhorio concebido como relação de fato, independente do direito. E a essa mera relação de fato, por vários motivos, concederam os juristas uma defesa especial, não definitiva, os interdicta possessoria, contra o próprio dominus e contra terceiros". Assim, no ensinamento de Miranda Rosa, o jus possidendi seria uma decorrência do direito de propriedade, sendo a própria atuação externa do domínio e, portanto, uma posse derivada, enquanto o jus possessionis (posse autônoma) seria origem de direitos, instituto isolado e independente da propriedade, sendo, portanto, posse originária.

Também para Ravail, a origem histórica da posse está no período anterior à época clássica romana, considerando que a possessio do ager publicus é a origem da posse $\mathrm{e}^{23}$.

Para Maria Helena Diniz, "não há um entendimento harmônico a respeito da origem da posse como estado de fato legalmente protegido" 24 . Porém, Pedro Henrique de Miranda Rosa apresenta três razões históricas para a existência de mecanismos de defesa da posse ${ }^{25}$ :

\footnotetext{
${ }^{21}$ Roberto Senise Lisboa. Manual de Direito Civil, p. 60.

${ }^{22}$ Pedro Henrique de Miranda Rosa. Fontes Históricas da Teoria da Posse no Direito Civil Brasileiro, p. 15.

${ }^{23}$ Pierre-Julien Ravail. De L'object de la possession. Essai sur le droit romain, l'ancien droit français et le droit actuel, p. 35.

${ }^{24}$ Maria Helena Diniz. Curso de Direito Civil Brasileiro, Direito das Coisas, p. 31.

${ }^{25}$ Pedro Henrique de Miranda Rosa. Fontes Históricas da Teoria da Posse no Direito Civil Brasileiro, p. 24-25.
} 
(a) o ensinamento de Niebuhr, no sentido da defesa conferida aos que utilizavam o ager publicus durante a era republicana. Somente as ager privatus podiam ser suscetíveis de propriedade, o que não era o caso das ager publicus, longas áreas de terra de propriedade do Estado Romano, que deixava ao uso revogável, gratuito ou não de particulares, de forma que esses possessores não podiam defender-se contra turbações e esbulhos violentos por parte de terceiros, por meio das ações civis, a reivindicatória ou a negatória. Assim, por equidade, os pretores no Direito clássico e justinianeo passaram a estender e conferir a defesa também aos detentores da ager publicus;

(b) caberia tutela à posse em razão da aparência de direito que dela emanava; e

(c) lembrando a lição de Ihering, teria tido origem na atribuição provisória da coisa a uma das partes, no curso da reivindicatio, enquanto se resolvia o real proprietário, de forma a evitar a violência privada.

De fato, historicamente o "desenvolvimento jurídico da posse surge com o Direito Romano, o qual estabeleceu mecanismos específicos de tutela da posse em favor das pessoas fixadas no ager publicus (terras cultiváveis pertencentes ao Estado Romano, adquiridos por ocupação bélica) que sofriam turbação arbitrária em seu gozo" 26 .

Assim, diante das correntes acima indicadas, quanto à origem da posse, depara-se com o desafio de identificar o que surgiu primeiro: a posse em si, e depois os interditos que a protegem, ou os interditos, e a posse como sua consequência (ou seja, como consequência do processo reivindicatório).

Carlos Roberto Gonçalves enfrenta a discussão acerca da origem da posse enfrentando a anterioridade desta ou se a posse decorreu, na verdade, dos procedimentos interditais.

Como mencionamos, a primeira corrente, liderada por Niebuhr, seguido por Savigny, evoca fatos históricos da expansão de Roma e a necessidade de ocupar os novos territórios conquistados, que eram divididos em pequenas propriedades denominadas possessiones e

\footnotetext{
${ }^{26}$ Brunno Pandori Giancoli. Direito Civil, p. 361.
} 
então concedidas tais propriedades aos particulares, mas em regime diferente da propriedade quiritária. Completa Gonçalves que "não podiam por isso, ser defendidas pela reivindicativo, restrita ao titular da propriedade. Para que não permanecessem indefesas, criou-se um processo especial, inspirado nas formas de defesa da propriedade, denominado interdito possessório".

A segunda corrente, na qual se inclui Ihering, defende que, contrariamente, o processo reivindicatório pré-existente deu origem à posse, no sentido de que "os interditos possessórios, na sua origem, constituíam incidentes preliminares do processo reivindicatório. Antes que este assumisse forma contenciosa regular em juízo, o pretor podia entregar a posse da coisa litigiosa a qualquer das partes. (...) Depois, (...) esse processo preparatório adquiriu independência, desvinculando-se do petitório" 27.

Como mencionado acima, Niebuhr, seguido por Savigny, adotou a primeira tese, baseado no contexto histórico da expansão de Roma, que dividia os novos terrenos em duas categorias, uma para crescimento das cidades e outra para ser dividida entre os cidadãos. Mas a velocidade com que esse processo expansionista ocorreu exigiu a solução prática de outorgar terrenos à título precário ou, no ensinamento de Washington e Maluf, "lotear essas áreas em pequenas propriedades, denominadas possessiones" 28, pois tais concessionários não podiam invocar os meios de reivindicação para defesa de tais terras; para não ficarem desamparados, "criou-se processo especial e próprio para proteção das terras assim concedidas".

Ensina Limongi França, no tocante à origem da posse, que "num certo sentido, a posse, o fato da apreensão de uma coisa, por parte da pessoa, como se fosse sua, remonta à própria origem do Homem (...)", indicando ainda que "a propriedade particular de certos bens existe desde sempre e, naturalmente, antes do direito escrito a sua forma rudimentar - foi a posse". Continua referido autor, abrangendo o período romano, a explicar que "durante as suas conquistas os romanos reservavam - parte das terras ocupadas para a construção de cidades e parte para o uso privado dos cidadãos. Entretanto, as vitórias sucessivas faziam com que as áreas destinadas às cidades se multiplicassem em demasia, tornando-se por

${ }^{27}$ Carlos Roberto Gonçalves. Direito Civil Brasileiro, Direito das coisas, p. 48.

${ }^{28}$ Washington de Barros e Carlos Alberto Dabus Maluf. Curso de Direito Civil, Direito das coisas, p. 33. 
vezes inaproveitadas e improdutivas. Daí lotearem essas áreas em pequenas glebas, denominadas possessiones, atribuídas aos cidadãos a título precário. Os concessionários não podiam usar a reivindicatio para defendê-las como se fossem proprietários; entretanto, para que não ficassem indefesos, o que seria iníquo, criou-se um procedimento especial para a proteção dessas terras, a saber o interdito possessório" 29.

Para expressar a origem histórica da posse, Manuel Rodrigues também recorre à lição de Niebuhr. Com a expansão romana, diversos territórios eram incorporados, porém não utilizados (ager publicus); para não restarem improdutivos, passaram a ser distribuídos aos particulares, divididos em pequenas propriedades denominadas possessiones. Continua o ilustre doutrinador português: "Como essas concessões eram feitas a título precário e tinham, portanto, uma natureza diferente da propriedade quiritária, aos concessionários não se permitia defender o seu direito pela reivindicatio; mas porque não podia ficar sem defesa, criou-se para eles um processo próprio e naturalmente inspirado nas formas de defesa da propriedade. Esse processo foi o interdito possessório"30.

Apreendendo o ponto principal e mais relevante da proteção possessória, menciona Astolpho Rezende que "o que é verdade é que a necessidade de proteger a posse nunca foi seriamente contestada; o que há é falta de unanimidade sobre a origens e os motivos dessa proteção"

Para Ihering, a posse tornou-se entidade própria e autônoma, em virtude dos incidentes preliminares do processo reivindicatório. Isso porque em uma primeira fase do processo, o pretor poderia conferir a posse da coisa litigiosa a algum dos contendores. Apesar de receber a posse nessas condições, ambas as partes deveriam fazer prova de seu direito sobre a coisa. Com o tempo, isso mudou, e quem estava já na posse da coisa nada precisava provar, apenas aquele que a reivindicava, de forma que foi caindo também em desuso o arbítrio inicial do pretor sobre quem ficaria com a posse da coisa, passando esta "a ser então atribuída a um dos litigantes, de acordo com um processo preliminar, que

${ }^{29}$ R. Limongi França. A Posse no Código Civil, p. 14-15.

${ }^{30}$ Manuel Rodrigues. A posse - Estudo de Direito Civil Português, p. 13. Aliás, muito equilibrada a opinião desde autor, no sentido de que "em Roma se gerou a posse, mas discute-se ainda hoje, porventura longe de uma solução, qual a causa que lhe deu origem. Nesse livro, não se toma partido por nenhuma das hipóteses que se referiam - essa atitude pertence aos romanistas" (p. 18).

${ }^{31}$ Astolpho Rezende. A posse e sua proteção, p. 26. 
antecedia ao reivindicatório",32. Para Washington e Maluf, trata-se de questão meramente acadêmica, que interessa aos romanistas, mas não aos civilistas.

Assim, parece-nos que a opinião majoritária dos doutrinadores quanto à origem mais provável da posse decorre da divisão e distribuição da ager publicus aos particulares de Roma, que passaram a contar com mecanismo de defesa possessório (os interditos), à semelhança da defesa conferida às demais propriedades privadas. Mais tarde, as possessiones passaram a ser consideradas verdadeiras propriedades, mas permaneceu a defesa proporcionada pelos interditos.

Quanto à experiência legislativa brasileira no tocante à posse, Lafayette, em sua obra clássica sobre o Direito das Coisas finalizada em 1877, denotava a falta de legislação específica no Brasil de então. Ainda faltariam vários anos até que o Código Civil entrasse em vigor no ano de 1916. Indicava Lafayette que a legislação de então (anterior ao Código Civil de 1916) era totalmente omissa acerca da posse, nada prevendo sobre sua natureza ou forma de aquisição e perda. Destaca que existiam apenas algumas disposições esparsas sobre os remédios possessórios nas Ordenações Filipinas e em algumas leis extravagantes, indicando, sem deixar de nos causar surpresa que, "nesse importantíssimo assunto, continua a vigorar o direito romano, com as modificações introduzidas pelo uso moderno e pela prática de julgar" ${ }^{, 3}$. Indicava, ainda, Lafayette que a visão de fato que impregnava o Direito romano era contrária à visão moderna da sistematização de direitos, indicando haver grande esforço para subordinar a posse ao princípio do Direito, tanto quanto sua natureza pudesse permitir.

A variação do conceito da posse no tempo leva à contradição entre textos de épocas distintas, bem como à divergência de opinião dos jurisconsultos que se preocupavam mais com os problemas do momento que com estruturas jurídicas. Sabemos hoje que a posse romana por si só sofreu mutações com o decorrer do tempo, recebendo posteriormente influência da gewere (instituto correspondente à posse no Direito germânico medieval) e ainda do conceito de posse desenvolvido pelo Direito canônico. O resultado é, na opinião de Moreira Alves, a "combinação de elementos históricos heterogêneos, que se mesclaram

\footnotetext{
${ }^{32}$ Washington de Barros e Carlos Alberto Dabus Maluf. Curso de Direito Civil, Direito das coisas, p. 34.

${ }^{33}$ Lafayette Rodrigues Pereira. Direito das Coisas, p. 25-26.
} 
por motivos de ordem étnica, religiosa e cultural. A isso tudo, acrescentam-se ainda as ideias trazidas no século XIX por Savigny e Ihering”. No Brasil, essa síntese de diferentes posturas também é sentida, na explicação de Moreira Alves, quando da elaboração do Código Civil de 1916, buscando Clóvis Beviláqua abstrair a doutrina de Ihering, mas sofrendo influência também do código germânico e influências de Savigny ${ }^{34}$.

\subsection{OBJETO DA POSSE}

Posse corresponde ao poder de fato sobre coisa corpórea, na acepção do Direito romano. Subordinação física (enquanto a propriedade é poder jurídico absoluto, um direito), pois, como já analisado, nihil commune habet proprietas cum possessione (não há nada em comum entre propriedade e posse). ${ }^{35}$

Ainda no Direito romano, sob a denominação de possessio, estavam incluídas várias situações que, mesmo tendo elementos comuns, possuíam estrutura diversa e diferentes consequências jurídicas ${ }^{36}$ :

(a) Possessio naturalis, chamada também de possessio corpore, correspondia à simples detenção, ou seja, o elemento material que constitui a base da posse; encontrando-se menção também a naturaliter possidere, de detinere, de ter a facultas restituendi. São termos equivalentes, que denotam a detenção; encontrava-se a possessio naturalis com o condutor, o depositário, o comodatário, as pessoas desprovidas de capacidade, como o escravo e a criança. A detenção não apresentava nenhuma tutela jurídica; todavia, constituiu a base das outras relações de posse tuteladas pela lei e,por si só depois passou a ser considerada.

(b) Possessio, desprovida de outra qualificação, indicava uma relação de fato que se estabelecia com a detenção acompanhada da vontade de ter a coisa para si. Era a categoria mais frequente e importante e foi precisamente em relação a ela que se elaborou a doutrina do instituto: consiste na possessio naturalis ou possidere corpore, ou seja, na detenção, à

\footnotetext{
${ }^{34}$ José Carlos Moreira Alves. Posse, V. I. Evolução Histórica, p. 1-3.

${ }^{35}$ Thomas Marky. Curso Elementar de Direito Romano, p. 74.

${ }^{36}$ Biondi Biondo. Istituzioni di Diritto Romano, p. 324-325.
} 
qual se adiciona um elemento subjetivo, o animus rem sibi habendi. Contra determinadas hipóteses de despojo violento ou de turbação na posse, o pretor determinava algumas interdições; por isso, também era chamada pelos intérpretes de possessio ad interdicta.

(c) Possessio civilis é a mesma possessio, fundada, porém, em uma iusta causa, isto é, em uma relação reconhecida como idônea, pelo ius civile, a transferir o dominium. A possessio civilis é aquela posse que a lei requer para adquirir o dominium por usucapião, por isso é chamada pelos intérpretes de possessio ad usucapionem. Qualifica-se como civilis, porque contém elementos civis tais quais a iusta causa e, adiada pelo tempo requerido pela lei, produz a consequência civil, que é a aquisição do domínio; também denominada possessio bonae fidei, uma vez que é aquela posse que conduz à usucapião. A possessio civilis, antes da ocorrência da usucapião, era tutelada pelo pretor por meio da actio Publiciana.

(d) possessio, na linguagem clássica, também era usada para denominar algumas relações especiais tuteladas pelos magistrados mediante adequadas actiones in rem; assim, havia a possessio de ager tributarius, stipendiarius, vectigalis.

Ebert Chamoun ${ }^{37}$ divide o estudo do instituto destacando os tipos de posse no Direito clássico e no Direito justinianeo, indicando as suas características. São os seguintes os tipos de posse no Direito clássico:

(a) possessio civilis, que causa a aquisição da propriedade ex iure Quiritium mediante o decurso do tempo, equivalendo à possessio ad usucapionem, desde que presente o animus domini. Uma vez havendo o requisito da possessio iusta, fundamentado em justo título (iusta causa) e boa-fé, poderia ser configurada a usucapião.

(b) possessio ad interdicta, com base apenas no animus possidendi e protegida pela proteção interdital.

(c) possessio naturalis / corporalis, que equivale à detenção, na verdade não caracteriza posse.

\footnotetext{
${ }^{37}$ Ebert Chamoun. Instituições de Direito Romano, 231.
} 
Em complementação, menciona os seguintes tipos de posse no Direito justinianeo:

(a) possessio civilis (possessio ad usucapionem e possessio ad interdicta), abrangendo conjuntamente a posse baseada em uma justa causa, ou considerada idônea pelo ius civile (ex iusta causa).

(b) possessio naturalis / corporalis: a detenção. A possessio iusta passa a ser apenas a posse fundada em justo título, independentemente dos outros requisitos.

(c) possessio animo e possessio corpore: na primeira, não há disponibilidade física da coisa, mas se mantém "pelo desejo do titular de conservá-la"; na segunda não está presente o animus domini, abrangendo-se desde a mera detenção até a posse de má-fé.

(d) possessio pro suo e possessio pro alieno: na primeira, há posse do proprietário ou posse de boa-fé; na segunda, estão abrangidas a detenção, a posse revogável, a posse injusta e a posse de má-fé.

No ensinamento de Bonfante, posse (possessio) significa, para os romanos, uma tal relação de fato com a coisa que permita dispor plenamente, em conjunto com a efetiva intenção de dispor como proprietário; o significado da palavra é de autoridade real, de uma dominação de fato sobre a coisa ${ }^{38}$. Assim concebida essa relação, esta não exprime senão aquilo que por regra é o conteúdo da propriedade; a posse consiste na sua imagine esteriore (imagem exterior).

Da mesma forma, a propriedade não é outra coisa senão a posse munida de uma verdadeira garantia jurídica, e alguns casos de possessio, como o habere in bonis, tornaram-se efetivamente formas de propriedade. Significando a intenção de querer ser proprietário de uma coisa, de querer dela dispor plenamente, os romanos usam a expressão animus ou affectio possidendi, porque, conforme apresenta Bonfante, de fato o ânimo de quem toma um animal caçado, descobre um tesouro ou aceita um livro em doação está dirigido a

\footnotetext{
${ }^{38}$ Pietro Bonfante. Istituzioni di Diritto Romano, 312.
} 
conseguir a autoridade de fato sobre tais coisas, e não importa que se tenha claro conhecimento de que aquele fato está garantido por existir o direito de propriedade subjacente.

A posse apresenta todos os aspectos externos do domínio - imago dominii; todavia para Serpa Lopes, há um aspecto "bizarro", pois a posse pode ou não coincidir com o domínio "como se alguém estiver exercendo-a em relação ao que não lhe pertence", por força do elemento vontade. Esta "expressão instintiva da vontade" seria um obstáculo a sua inclusão na categoria de direitos reais ${ }^{39}$.

Assim, propaga Venosa que a posse coincide com estado de aparência que merece proteção: "a cada instante, defrontamos com situações aparentes que tomamos como verdadeiras e corretas". Ainda, "se a sociedade não pode prescindir da aparência para sua sobrevivência, o Direito não pode furtar-se de proteger estados de aparência, sob determinadas condições, porque se busca, em síntese, a adequação social. Sempre que o estado de aparência for juridicamente relevante, existirão normas ou princípios gerais de direito a resguardá-lo. Como não é possível ficar questionando se todas as relações entre pessoas e coisas são efetivamente legítimas (...) em prol do resguardo da verdadeira acomodação social, cabe ao Direito fornecer meios de proteção àqueles que se mostram como aparentes titulares de direito. Não fosse assim, restabelecer-se-ia a justiça de própria mão, dos primórdios da civilização" ${ }^{40}$, e sabemos que o ordenamento jurídico veda o exercício arbitrário das próprias razões. Desta forma, a posse trata de estado de aparência juridicamente relevante, ou seja, estado de fato protegido pelo direito.

Ensina Silvio Rodrigues que “(...) a posse, situação de fato, vai ser protegida. Vai ser protegida porque aparenta ser uma situação de direito; e, enquanto não se demonstrar o contrário, tal situação prevalecerá. (...) Portanto, numa primeira conclusão, poder-se-ia dizer que a posse, mera situação de fato, vai ser protegida pelo legislador, não só porque

\footnotetext{
${ }^{39}$ Miguel Maria de Serpa Lopes. Curso de Direito Civil. Direito das coisas. Vol. VI, p. 86.

${ }^{40}$ Silvio de Salvo Venosa. Código Civil Comentado Vol. XII - Coordenador Álvaro Villaça Azevedo, p. 19-20.
} 
aparenta uma situação de direito, como para evitar que prevaleça a violência"41 (grifos nossos).

A posse, sendo um valor social, deve ser protegida para preservar a manutenção da paz social, conforme a lição de Kohler, lembrada por Humberto Theodoro Junior: "A razão de ser dessa proteção legal a uma situação simplesmente de fato, sem indagar de sua origem jurídica, está em que, segundo Kohler ao lado da ordem jurídica, existe a ordem da paz, que, por muitos anos, tem-se confundido, não obstante o direito ser movimento e a paz tranquilidade. A essa ordem da paz pertence a posse, instituto social, que não se regula pelos princípios do direito individualista. A posse não é instituto individual, é social; não é instituto de ordem jurídica e sim da ordem da paz. Mas a ordem jurídica protege a ordem da paz, dando ação contra a turbação e a privação da posse" ${ }^{, 42}$.

Em linhas gerais e de forma ampla, portanto, consiste a posse em exercício de fato de um direito sobre uma coisa, independentemente de ser esse direito exercido pelo efetivo titular $^{43}$. Aliás, como já ensinava Bonfante, no sentido de que a posse é a imagem normal e natural do domínio, ela pode bem estar desacompanhada do domínio ${ }^{44}$. Assim, uma importante característica da posse, de consistir no poder físico sobre a coisa, também pode abranger a exterioridade da propriedade.

Para Bruno Giancoli, a posse pode ser "entendida como um estado de fato de quem mantém sobre uma determinada coisa, uma relação de controle, de poder"45. Ou ainda, como indica Tito Fulgêncio, a posse exprime em regra o conteúdo da propriedade ${ }^{46}$.

A posse, para Paula Costa e Silva, é "uma situação jurídica marcada pela finalidade, apresentando-se, estruturalmente, como situação jurídica real" ${ }^{47}$.

\footnotetext{
${ }^{41}$ Silvio Rodrigues. Direito das Coisas, p. 16.

${ }^{42}$ Humberto Theodoro Junior. Posse e Propriedade, p. 5.

${ }^{43}$ Pedro Henrique de Miranda Rosas. Direito Civil - Direito das coisas, p. 12.

${ }^{44}$ Pietro Bonfante. Istituzioni di Diritto Romano, 312.

${ }^{45}$ Brunno Pandori Giancoli. Direito Civil, p. 361.

${ }^{46}$ Tito Fulgêncio. Da posse e das ações possessórias. Vol. I, p. 7.

${ }^{47}$ Paula Costa e Silva. Posse ou Posses?, p. 73.
} 
Reforça ainda Orlando Gomes que “o que importa é o uso econômico, a destinação das coisas, a forma econômica de sua relação exterior com a pessoa. (...) Qualquer pessoa é capaz de reconhecer a posse pela destinação econômica da coisa. Sua existência se atesta por sinais exteriores. Ela torna visível a propriedade" ${ }^{48}$.

Ihering já mencionava que a propriedade destituída da posse se torna deficiente quanto à sua utilidade econômica, não apresentando qualquer valor econômico. Desdobrando esse raciocínio, Ihering afirma que uma posse sem aproveitamento econômico será a coisa mais sem valor do mundo. O seu valor existirá quando atender a função de aproveitamento econômico, é um meio para alcançar uma finalidade. Por isso, há um interesse que se prende à posse, a posse constitui a condição para utilização econômica da coisa ${ }^{49}$.

Assim, para Ihering, a posse seria a propriedade em seu estado normal, "a posse é o sinal exterior, a visibilidade da propriedade". Chega referido autor a dizer que, estatisticamente, a presença desse sinal exterior (posse como exteriorização da propriedade) coincide com a propriedade real na maioria dos casos; de maneira geral, o possuidor é o proprietário designando o possuidor como o proprietário presumido, merecendo a defesa possessória. Assim, a ação possessória revela a propriedade na defensiva, enquanto a reivindicatória nos mostra a propriedade no ataque. Desta forma, no ensinamento de Ihering, exigir daquele que defende sua posse a prova da propriedade seria proclamar que todo indivíduo que está sem condições de fornecer a prova ${ }^{50}$ de sua propriedade está fora da lei (agindo de forma ilegal).

Tito Fulgêncio considera, assim, que "a posse nada mais é que o modo por que a propriedade é utilizada; a relação de fato estabelecida entre a pessoa e a coisa pelo fim de sua utilização econômica; possuidor é qui omnia ut dominium facit", concordando o autor que a visão de Ihering foi mantida na essência pelo Código Civil de $1916^{51}$, como trataremos adiante.

\footnotetext{
${ }^{48}$ Orlando Gomes. Direitos Reais, atualização Luis Edson Fachin, p. 35.

${ }^{49}$ Rudolf von Jhering. Ouevres Choisies, Possession. Théorie simplifiée et mise à la portée de tout le monde, p. 217 .

${ }^{50}$ E seria para Savigny também muito difícil demonstrar essa propriedade em grande número dos casos, especialmente no caso de bens móveis. Rudolf von Jhering. Ouevres Choisies, Possession. Théorie simplifiée et mise à la portée de tout le monde, p. 230-231.

${ }^{51}$ Tito Fulgêncio. Da posse e das ações possessórias. Vol. I, p. 10.
} 
Já previne Venosa que "sem a credibilidade da sociedade nos estados de aparência, inviável seria a convivência”. Há situações aparentes que são tomadas como verdadeiras e corretas. Por isso, deve o Direito preservar e proteger situações de aparência em certas ocasiões, decorrendo dessa premissa que "sempre que o estado de aparência for juridicamente relevante, existirão normas ou princípios gerais de direito a resguardá-lo" 52 . Aparência com relevância social e jurídica apresenta valor jurídico e social, portanto - até porque seria inimaginável permanentemente questionar a demonstração da efetividade/juridicidade de tais situações.

Ihering apresenta também exemplos de coisas que não estão sob o poder imediato de fato do possuidor, ainda assim havendo posse (pois posse é a exteriorização da propriedade), como no exemplo do camponês, indicado em sua obra Teoria Simplificada da Posse. Muitos dos objetos de trabalho do camponês não se encontram guardados em sua casa, mas dispostos no campo, uma vez que sua destinação econômica exige que eles fiquem no descoberto, como as ervas, o feno, a palha, a madeira colhida na floresta, o combustível, o carvão obtido nas minas, o material de construção próximo à obra; também os animais domésticos que vivem livremente, o gado no pasto, e os escravos entre os romanos ${ }^{53}$. Em todos esses casos, não há poder físico sobre a coisa; entretanto a sua posse é de igual forma protegida juridicamente.

O mesmo raciocínio se aplica, para Ihering, aos imóveis, pois mesmo os imóveis que não são fechados com muros ou cercas merecem proteção.

A razão última da posse é possibilitar o uso econômico da coisa; e cada coisa (de acordo com sua natureza) terá uma relação distinta com o possuidor (por exemplo, dinheiro e pedras preciosas serão guardados em casa, enquanto o arado ficará no campo). "Cada um sabe o que fazer com suas coisas, de acordo com suas características, e é esse aspecto normal da relação do proprietário com a coisa que constitui a posse" ${ }^{\mathbf{5 4}}$.

\footnotetext{
${ }^{52}$ Silvio de Salvo Venosa. Direitos Reais, p. 27.

${ }^{53}$ Rudolf von Jhering. Ouevres Choisies, Possession. Théorie simplifiée et mise à la portée de tout le monde, p. 247.

${ }_{54}^{5}$ Ibid., p. 248.
} 
Assim, não é possível explicar a posse apenas pelo poder de fato, poder físico; a posse se molda e adapta às características das coisas; certas coisas comumente são utilizadas mediante o poder de fato, mas outras coisas não - e, ainda assim, nesta última hipótese, haverá posse, em vista da relação econômica normal da pessoa com a coisa.

Humberto Theodoro Júnior indica como conceito de posse, espelhado no Código Civil de 1916, aquele desenvolvido por Ihering, sendo possuidor aquele que tem de fato o exercício pleno, ou não, de alguns dos poderes inerentes ao domínio ou à propriedade. Lembra a lição de Clóvis Beviláqua, no sentido de que a posse deve ser protegida contra esbulhos e turbações, por consistir na relação de fato estabelecida entre a pessoa e a coisa pelo fim de sua utilização econômica, pois, para Clóvis Beviláqua, posse era "a visibilidade da propriedade, ainda que a sua proteção possa favorecer a quem não é proprietário, nem exerça algum direito real (Clóvis, Direito das Coisas, V. I, p. 30)". Assim, conclui Humberto Theodoro: "tanto tem posse o dono como o seu comodatário ou seu locatário, porque todos eles praticam fatos que, sobre o objeto que incidem, representam maneiras de exteriorização prática do domínio" ${ }^{55}$.

Para Ihering, "a posse é tão economicamente necessária como a propriedade; ambas não passam de formas jurídicas sob as quais realiza-se o destino econômico das coisas para satisfazer as necessidades da humanidade ${ }^{56}$.

Desta forma, passaremos a tratar, no capítulo seguinte, de forma mais detalhada, acerca do conceito e conteúdo da posse.

Ressalte-se que muito também foi debatido, especialmente no Brasil, sobre a possibilidade de a posse alcançar direitos; sobre a posse de direitos, trataremos no item 1.8.

\footnotetext{
${ }^{55}$ Humberto Theodoro Junior. Posse e Usucapião, p. 73-74.

${ }^{56}$ Rudolf von Ihering. Fundamentos dos Interditos Possessórios, p.21.
} 


\subsection{CONCEITO E CONTEÚDO DA POSSE}

No ensinamento de Thomas Marky, no Direito romano, o conteúdo da posse sempre era composto de dois elementos: (i) um elemento material; e (ii) um elemento intencional ${ }^{57}$.

O elemento material consiste no corpus, representado pela subordinação física da coisa à pessoa, que depende das circunstâncias.

O elemento intencional consiste no animus. É a intenção de possuir, o animus possidendi. Assim, não basta haver apenas a subordinação física, pois deve estar presente também a intenção de possuir. O exemplo oferecido pelo referido romanista consiste no ladrão que deixa desapercebidamente no bolso de terceiro uma carteira; este terceiro não possui tal carteira.

Por esta razão, tradicionalmente se alega que os dois elementos, material e intencional, devem estar simultaneamente presentes, pois o bem tem que estar na esfera da ação do possuidor. Assim, haverá posse sobre uma galinha que foge para o terreno do vizinho, mas não em relação ao pássaro que fugiu da gaiola, também em outro exemplo de Marky.

No ensinamento de Bonfante, a posse apresenta dois elementos: a disponibilitá della cosa (disponibilidade da coisa), isto é, uma relação que possibilite o uso econômico e social, segundo a natureza diversa da coisa, além de se poder agir quando se queira sobre essa, com a intenção de tê-la como própria (l'intenzione di tenerla come propria). O primeiro, elemento material, é indicado pelos romanos com as expressões tenere ou detinere, esse in possessione, possessio naturalis ou corporalis, possessio ou possidere corpore; o segundo, o elemento espiritual, identificado pelo animus ou affectio possidendi, animus rem sibi habendi. $\mathrm{Na}$ linguagem dos doutrinados, animus possidendi tornou-se simplesmente animus, e a antítese possessio corpore foi resumida na palavra corpus, o que seria um grande equívoco para Bonfante, pois corpo (corpo) significa em latim o mesmo que em italiano, ou seja, o corpo humano ou a coisa em si, e nunca a sua detenção material ${ }^{58}$.

\footnotetext{
${ }^{57}$ Thomas Marky. Curso Elementar de Direito Romano, p. 74.

${ }^{58}$ Pietro Bonfante. Istituzioni di Diritto Romano, p. 314-315.
} 
Com relação ao corpus, indica Ascensão que “(...) não se exige contato material mas só a possibilidade desse contato (...)", bastando "uma relação de pessoa e coisa que exprima a subordinação da coisa à vontade da pessoa - expressa na possibilidade de continuar o gozo - para que o corpus exista”. Por isso, “o corpus já é em si uma relação - não material, mas social". Por outro lado, com relação ao animus, apresenta que este "só poderia ser assim a intenção de agir como o titular do direito a que o exercício do poder de fato se refere". Ihering prescinde da vontade do possuidor, lembrando Ascensão que "para Ihering, sempre que houvesse relação de fato haveria posse, salvo se disposição particular de lei a viesse excluir em certos casos, relegando-a a mera detenção" 59 .

Para Girard, de acordo com as fontes romanas, a posse poderia ser entendida como o exercício da propriedade manifestada pelos seus sinais exteriores, compreendendo normalmente um fato material e voluntário, com dois elementos, um elemento material chamado corpus e um fato intencional denominado animus, habitualmente chamado de animus domini, no qual há intenção de se manifestar como proprietário (intenção de possuir $)^{60}$, seguindo portanto a visão de Savigny.

Também para Venosa ${ }^{61}$, o conceito de posse abrange os dois elementos: (i) Corpus: a ligação material do homem com a coisa, representando a exterioridade da propriedade; e (ii) Animus: o elemento subjetivo - a intenção sobre a coisa.

Para Carlos Alberto Bittar, da mesma forma, “(...) a ação física deve acompanhar-se do elemento psicológico, para que possa produzir efeitos na órbita jurídica"62.

No tocante à independência entre os conceitos, ressalta o professor Bittar que “(...) em nosso Código, e como anotamos, reveste-se [a posse] de essencialidade própria, distinta da do direito de propriedade, não se reduzindo a mera exteriorização deste, ou de simples fato gerador. Apresenta, em verdade, essas características, revela-se direito autônomo, com a reunião dos elementos objetivo (corpus ou poder sobre a res) e subjetivo (animus ou

\footnotetext{
${ }^{59}$ José de Oliveira Ascensão. Direito das Coisas - reais, p. 83-85.

${ }^{60}$ Paul Frédéric Girard. Manuel Élémentaire de Droit Romain, p. 164-265.

${ }^{61}$ Silvio de Salvo Venosa. Código Civil Comentado Vol. XII - Coordenador Álvaro Villaça Azevedo, p. 27.

${ }^{62}$ Carlos Alberto Bittar. Direitos Reais, p. 30.
} 
intenção de tê-lo sob a ação própria). Pode existir sem o direito de propriedade e mesmo em concorrência com este, nos desdobramentos possíveis (como na locação, na alienação fiduciária, no usufruto e em outras situações)".

No entender de Serpa Lopes, apenas o poder de fato sobre a coisa (corpus) não basta para explicar a posse, sendo imprescindível o elemento subjetivo (animus), quer seja visto sob o prisma da teoria subjetiva, quer seja visto sob o prisma da teoria objetiva: "quer se considere esse elemento subjetivo - animus - como uma figura distinta do corpus, como pretende Savigny, quer seja encarado, como pretende Ihering, como ínsito ao próprio comportamento do possuidor, cujo modo de ser já indica, por si mesmo, esse conteúdo anímico" 63 .

Ravail apresenta a evolução que a ideia de posse teve desde a Idade Média, quando os glosadores a entendiam essencialmente como a detenção de uma coisa corpórea, a apreensão material, ter a coisa em seu poder e controle. Com Savigny, esse conceito sofre alterações: basta que a coisa esteja à disposição para o sujeito realizar seu poder e controle quando ele desejar, sendo a possibilidade de agir sobre uma coisa, excluindo todas as outras pessoas. E com Ihering, passa a ser a exteriorização da propriedade, não sendo necessário o poder efetivo nem o poder iminente sobre a coisa. Assim, a exteriorização é o estado normal da coisa, aquele em que a coisa se encontra normalmente para atender a sua destinação econômica de servir aos homens ${ }^{64}$.

Segundo Coelho da Rocha, para haver posse no sentido jurídico "é necessário, além da detenção, o ânimo de ter ou dispor da coisa como própria, ou ao menos de dispor dela em seu próprio nome, ainda que a propriedade seja de outrem" 65 .

O nosso Código Civil conferiu o conteúdo eminentemente objetivista (segundo Ihering) aos artigos 1.196 e 1.197, que guardam a definição da posse, não sem possibilitar também que esta se desdobre em direta e indireta, conforme a atual redação no Código Civil:

\footnotetext{
${ }^{63}$ Miguel Maria de Serpa Lopes. Curso de Direito Civil. Direito das coisas. Vol. VI, p. 88.

${ }^{64}$ Pierre-Julien Ravail. De L'object de la possession. Essai sur le droit romain, l'ancien droit français et le droit actuel, p. 4.

${ }^{65}$ M. A. Coelho da Rocha. Instituições de Direito Civil - tomo II, p. 255.
} 
Art. 1.196. Considera-se possuidor todo aquele que tem de fato o exercício, pleno ou não, de algum dos poderes inerentes à propriedade.

Art. 1.197. A posse direta, de pessoa que tem a coisa em seu poder, temporariamente, em virtude de direito pessoal, ou real, não anula a indireta, de aquela foi havida, podendo o possuidor direto defender a sua posse contra o indireto. $^{66}$

${ }^{66}$ O Deputado Ricardo Ferreira Fiúza, do Partido Progressista, propôs a alteração de diversos dispositivos do atual Código Civil (Lei n ${ }^{\circ}$ 10.406/2002), dentre eles os artigos 1.196 e 1.197, que tratam a respeito da posse. Atualmente, o projeto $\mathrm{n}^{\circ}$ 699/2011de alteração ao atual Código encontra-se arquivado na Mesa Diretora da Câmara dos Deputados desde 17 de março de 2008, com base no artigo 105 do Regimento Interno da Câmara dos Deputados: "Art. 105. Finda a legislatura, arquivar-se-ão todas as proposições que no seu decurso tenham sido submetidas à deliberação da Câmara e ainda se encontrem em tramitação, bem como as que abram crédito suplementar, com pareceres ou sem eles (...)". O projeto propunha a seguinte redação da criação de Joel Dias Figueira Jr., com a respectiva justificativa no que concerne às teorias sociológicas da função social da propriedade, indicando este autor que foram "as teorias sociológicas da posse, a partir do início do século XX, na Itália com Silvio Perozzi, na França com Raymond Saleilles e, na Espanha, com António Hernández Gil, que não só colocaram por terra as célebres teorias objetiva e subjetiva de Jhering e Savigny, como também tornaram-se responsáveis pelo novo conceito desses importantes institutos no mundo contemporâneo, notadamente a posse, como exteriorização da propriedade":

"Art. 1.196. Considera-se possuidor todo aquele que tem poder fático de ingerência socioeconômica, absoluto ou relativo, direto ou indireto, sobre determinado bem da vida, que se manifesta através do exercício ou possibilidade de exercício inerente à propriedade ou outro direito real suscetível de posse."

"Art. 1.197. A posse direta dos bens, mesmo que em caráter temporário e decorrente de direito pessoal ou real, não anula a posse indireta de quem foi havida, podendo, qualquer um deles agir em sua defesa, inclusive por ato praticado pelo outro possuidor." 


\subsubsection{TEORIAS SUBJETIVA E OBJETIVA DA POSSE}

A teoria subjetiva da posse foi desenvolvida por Savigny, como resultado de seus estudos sobre as fontes do Direito romano. Nos termos dessa teoria, a posse é composta por dois elementos, o corpus (elemento físico, contato com a coisa, que permite a pessoa fazer o que quiser com ela) e o animus (não basta o elemento físico, é necessário ter a intenção de possuir, sendo o animus que distingue o possuidor do simples detentor).

A posse é ao mesmo tempo um direito e um fato; considerada em si mesma é um fato; considerada nos efeitos que gera (usucapião e interditos) ela se apresenta como um direito. Savigny entende a posse em dois planos, em sua essência é fato; e enquanto os efeitos que gera é direito, por dar origem às ações de usucapião e interditos da posse.

Por sua vez, a teoria objetiva da posse foi elaborada por Rudolof von Ihering. Nos termos dessa teoria, nem sempre o possuidor detém o corpus; também por vezes não é possível demonstrar o animus. O animus determina o destino econômico da coisa, como se dono fosse, ou como faria o proprietário. O animus e o corpus devem ser, portanto, integrados.

Para Ihering, a posse é um direito. Um direito subjetivo consistente em interesse juridicamente protegido.

Nesse sentido, para Ruy Barbosa, "o sistema objetivo caracteriza-se pela depressão do papel da vontade na posse. É fundamentalmente, com efeito, uma insurgência contra a significação que a teoria tradicional atribuiu ao elemento psicológico (animus). Não é a natureza particular da vontade de possuir, nem o poder físico do indivíduo sobre a coisa que distingue a posse, mas, antes, o exercício de fato dos poderes correspondentes a certos direitos, e, por isso mesmo, a sua exteriorização"67.

No ensinamento de Silvio Rodrigues, posse difere de outros direitos, porque ao surgir um direito, o fato que o originou deixa de existir. Isso não acontece com a posse, pois o direito

\footnotetext{
${ }^{67}$ Ruy Barbosa. Posse de direitos, p. 16.
} 
somente existe "enquanto a situação de fato existir (...) na posse, ao contrário, a manutenção da relação de fato é condição da sobrevivência do direito à posse" ${ }^{\text {"68 }}$.

No entendimento de Humberto Theodoro Junior" portanto, um elemento ético (o animus) e outro material (o corpus)", sendo este entendido como "a possibilidade física de dispor da coisa com exclusão de qualquer outra pessoa. $\mathrm{O}$ pensamento de Savigny foi combatido e suplantado por outro grande jusfilósofo alemão, Ihering, através da teoria denominada objetiva, que, entre nós foi ostensivamente esposada pelo Código Civil [de 1916]”.

Maria Helena Diniz ${ }^{70}$, por sua vez, indica que no sentido próprio (técnico) as duas referidas teorias que buscam definir posse apresentam as seguintes características:

(i) teoria subjetiva: acentua o elemento intencional como caracterizador da posse. A posse deve ser entendida como o poder de direito ou imediato que tem a pessoa de dispor fisicamente de um bem com a intenção de tê-lo para si e de defendê-lo contra a intervenção ou agressão de quem quer que seja.

Assim, são dois elementos constitutivos da posse, o corpus (elemento material, poder físico sobre a coisa ou a possibilidade de exercer esse poder, ou, dito de outra forma, a detenção do bem ou tê-lo à disposição) e o animus rem sibi habendi (animus domini), consiste na intenção de exercer sobre a coisa o direito de propriedade. Um não pode existir sem o outro, para configurar a posse jurídica.

Ressalta Maria Helena Diniz que "como consequência dessa doutrina, são tidos como meros detentores: o locatário, o comodatário, o depositário, o mandatário, enfim todos os que, por título análogo, tiverem poder físico sobre certos bens". E, por não serem possuidores, não gozam de ação para defender a posse, devendo recorrer àquele a quem se conferiu a detenção. "Portanto, pela teoria subjetiva é inadmissível a posse por outrem,

${ }^{68}$ Silvio Rodrigues. Direito das Coisas, p. 21.

${ }^{69}$ Humberto Theodoro Junior. Posse e Propriedade, p. 4.

${ }^{70}$ Maria Helena Diniz. Curso de Direito Civil Brasileiro, Direito das Coisas, p. 34-42. 
porque não podemos ter, para terceiro, a coisa com o desejo de que seja nossa, pois se não há vontade de ter a coisa como própria, haverá apenas detenção" ${ }^{71}$.

Savigny apresentou uma resposta a esta deficiência criando também a posse derivada, especialmente para alocar o poder detido pelo credor (o precarista e o depositário) para a defesa da coisa, uma vez que em Roma tais figuras não tinham ação própria para defender sua posse e, por consequência, o pretor outorgava a proteção possessória.

(ii) teoria objetiva: para haver posse, basta o corpus, não havendo necessidade do animus; esta teoria dispensa a intenção de dono. O corpus seria o único elemento visível e passível de constatação, sendo o animus ínsito ao corpus. Posse deve ser entendida como exterioridade ou visibilidade da propriedade - uma relação exterior intencional, existente normalmente entre o proprietário e sua coisa.

Continua esta autora dispondo que "para Ihering o que importa é o uso econômico ou destinação socioeconômica do bem, pois qualquer pessoa é capaz de reconhecer a posse pela forma econômica de sua relação exterior com a pessoa",72. Assim, o elemento principal é o corpus, enquanto exterioridade da propriedade, com desempenho de função econômica, estando o animus nele incluído, indicando um modo de atuação sobre o bem.

Moreira Alves, de forma a também explicitar as diferenças entre as duas teorias, apresenta o famoso esquema da posse segundo Savigny e Ihering, contendo as fórmulas algébricas (baseadas em Matos Peixoto) ${ }^{73}$ :

Savigny - há o corpus (que é C + A), mas precisa-se também do animus (representado por “a”) para ser posse; na detenção, não é encontrado o animus. Esta teoria parte da detenção para chegar à posse (com o acréscimo de "a"):

\footnotetext{
${ }^{71}$ Para Maria Helena Diniz, a teoria subjetiva da posse não condiz com a mentalidade jurídica moderna, não merecendo ser acolhida pelo mundo do direito (p. 36).

${ }^{72}$ Maria Helena Diniz. Curso de Direito Civil Brasileiro, Direito das Coisas, p. 37. Por fim, indica a autora que o Código Civil brasileiro acolheu doutrina objetiva: "Na sistemática de nosso direito civil, a posse não requer nem a intenção de dono nem o poder físico sobre o bem, apresentando-se como uma relação entre a pessoa e a coisa, tendo em vista a função socioeconômica desta” (p. 38).

${ }^{73}$ José Carlos Moreira Alves. Direito Romano. Vol. I, p. 325.
} 


$$
\begin{gathered}
P=C+A+a \\
D=C+A
\end{gathered}
$$

Ihering - há posse com apenas C + A (elementos objetivo e subjetivo). Esta teoria parte da posse para chegar à detenção (com a retirada do fator negativo " $n$ "):

$$
\begin{gathered}
P=C+A \\
D=C+A-n
\end{gathered}
$$

Em que:

$\mathrm{P}=$ posse

$\mathrm{C}=$ corpus (elemento material)

$\mathrm{A}=$ affectio tenendi (consciência, vontade de ter a coisa consigo)

$\mathrm{a}=$ animus domini

$\mathrm{n}=$ dispositivo legal que transforma posse em detenção

Segundo François Terré e Philippe Simler, "existem dois componentes da posse, identificados pelo direito romano: o corpus e o animus. O corpus é o elemento objetivo da

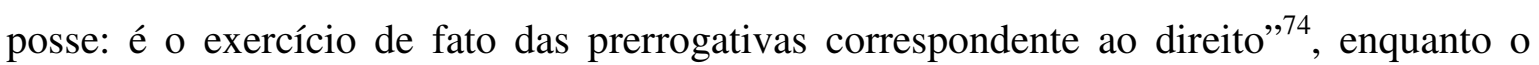
animus é “(...) um elemento psicológico, intencional. É o animus a intenção de se comportar como verdadeiro titular do direito; por exemplo, do ponto de vista do direito de propriedade, corresponderá à intenção de se comportar como o proprietário da coisa, o que se denomina animus domini ou animus rem sib habendi".

Apregoam os referidos autores que "para Savigny, o elemento determinante e verdadeiramente criador da posse real é o animus. O elemento distintivo da posse será o animus, a intenção que anima o possuidor: decorre deste fato o nome da teoria subjetiva, uma vez que atribui à vontade uma ação preponderante". Completam os doutrinadores franceses: "Esta intenção será a de agir como proprietário. Savigny coloca em oposição ao

\footnotetext{
${ }^{74}$ François Terré, Philippe Simler. Droit Civil - Les biens, p. 157.
} 
animus domini o animus detinendi, que corresponde à intenção de possuir por outro, que reduz o possuidor a um papel de simples detentor" ${ }^{\text {"75. }}$.

Por outro lado, para Ihering "será necessário abstrair ao máximo a intenção. O que importa mesmo é o fato exterior, objetivo, dos atos de utilização, originando o nome da teoria objetiva",76.

Ensina Edmundo Pereira Lins que, apesar de a posse ter composição dúplice, corpus e animus, tais elementos não existem individualmente, ambos surgem concomitantemente com a vontade incorporada à coisa. Em resumo, para Lins os elementos da posse poderiam ser esquematizados da seguinte forma ${ }^{77}$ :

Corpus: (a) para Savigny - apresenta o poder físico sobre a coisa e o poder de a defender contra terceiros; (b) para Ihering - consiste na exteriorização ou visibilidade da propriedade; agir normalmente como o proprietário frente a coisa, com reconhecimento dos demais.

Ademais, para Savigny, corpus com affectio tenendi resulta apenas em detenção.

Animus: (a) para Savigny - animus rem sibi habendi (intenção de ter a coisa para si); ou ainda, animus domini (intenção de dono ou proprietário da coisa); (b) para Ihering - é a affectio tenendi inerente ao corpus, agindo normalmente como o proprietário da coisa agiria.

Ruggiero denomina Teoria Romana da Posse todo o estudo realizado pelos romanistas acerca das origens e significados do instituto da posse. Apresenta a teoria de Savigny defendendo que o elemento de diferenciação entre a posse e a detenção é o animus, pois para Savigny este é determinante para a posse, "a vontade o fator soberano que transforma a detenção em posse" - a vontade de ter a coisa como sua, a intenção de exercer a propriedade.

\footnotetext{
${ }_{75}^{75}$ François Terré, Philippe Simler. Droit Civil - Les biens, p. 157.

76 Ibid., mesma página.

${ }^{77}$ Edmundo Pereira Lins. Estudos Jurídicos na Cátedra e na Judicatura. Ensaio sobre a Posse (direito romano e civil), p. 122.
} 
Assim, possuir em nome de outro (nomine alieno) não se correlaciona à posse, e aqueles que estão nessa posição "são detentores, por não terem, nem poderem ter, um animus domine, [como o] comodatário e o depositário; possuem eles nomine aliena e não nomine proprio, exercendo a sua atividade a favor da posse alheia, que permanecerá respectivamente do comodante e do depositante". O resultado é que somente à posse era dada a defesa do pretor, ficando a detenção desprovida de tutela.

Ademais, lembra Ruggiero que havia no Direito romano três casos excepcionais de proteção aos detentores: o credor pignoratício, o precarista, e o fiel depositário, havendo uma possessio derivada. "Assim, aquelas três figuras anômalas de possuidores destituídos de animus domini, e tratados, no entanto, como possuidores verdadeiros e próprios, eram pelo pretor englobados na regra geral, que não admite posse, e portanto também não admite defesa, sem o concurso de um animus qualificado". Ihering, por outro lado, em sua teoria objetiva, não nega a existência de elemento baseado na vontade, mas nega "que seja essencial à posse um animus particular e, especialmente, um animuys domini ou um animus rem sibi habendi; não existe também diferença entre o ânimo de ter a coisa como sua (nomine proprio) e o de a ter por outrem (nomine alieno $)^{78}$.

Moreira Alves faz importante ponderação, ressaltando que mais modernamente os romanistas ficam propensos a entender que ambas as teses de Ihering e Savigny são falhas pois "não atentaram para o fato de que a noção e as espécies de possessiones variaram durante a evolução do direito romano. E é essa evolução que explica a aparente contradição de textos redigidos em épocas diferentes, bem como a posse do precarista, do credor pignoratício e do depositário de coisa litigiosa" ${ }^{79}$.

No mesmo sentido, apregoa Rosa, indicando que o romanista Emilio Albertario revelou que as divergências entre as correntes objetiva e subjetiva decorrem na verdade de terem se baseado na interpretação dos textos romanos originados de períodos históricos diversos,

\footnotetext{
${ }^{78}$ Roberto de Ruggiero. Instituições de Direito Civil. Vol. II, p. 744-745.

${ }^{79}$ José Carlos Moreira Alves. Direito Romano. Vol. I, p. 329.
} 
pois enquanto Savigny consultava os textos do Direito romano clássico, Ihering se debruçava sobre o Direito bizantino, suscetível a mudança dos tempos ocorrida ${ }^{80}$.

Na opinião de Venosa, o sistema do atual Código Civil não se filia nem à teoria de Savigny, nem à teoria de Ihering, pois (a) para Savigny a posse dependeria da intenção, do animus de ser dono. Não existe esse animus para o locatário, usufrutuário, depositário etc., pela própria natureza da relação contratual envolvida; e (b) pela teoria de Ihering, haveria necessidade de exteriorização do domínio, o que não ocorre com o locador, nuproprietário, depositante, porque não se apresentam eles ostensivamente perante a sociedade como titulares do direito real. Assim, para o eminente doutrinador, a conclusão é no sentido de "que o Direito brasileiro adotou solução de ordem técnica, sem recorrer diretamente às fontes históricas tradicionais, embora inspirado no Código alemão, para dirimir questões de difícil deslinde nessas relações negociais, não se preocupando com a filiação numa ou noutra corrente doutrinária acerca da posse" ${ }^{\Perp 1}$.

Também para Humberto Teodoro Junior o nosso Código não deu guarida à teoria subjetiva: "Superada a conceituação de Savigny, nosso Código admite a posse, com ou sem o animus rem sibi habendi. (...) Daí a possibilidade de, por exemplo, o arrendatário exercer posse e defendê-la até mesmo contra ataques do proprietário locador; e ainda, a admissibilidade da coexistência de posses diretas e indiretas sobre a mesma coisa, em situações como a do usufruto e da locação" ${ }^{\text {"82. }}$.

À semelhante conclusão chega Venosa, no sentido de que nosso sistema inova ao adotar uma solução que não se alinha exatamente a nenhuma teoria: “(...) sustenta-se que, embora o ordenamento nacional tenha adotado a teoria objetiva, abre válvulas para o exame subjetivo das características da posse, notadamente na posse ad usucapionem, não ocorrendo adesão servil do legislador à teoria objetiva da posse" ${ }^{, 83}$.

\footnotetext{
${ }^{80}$ Pedro Henrique de Miranda Rosas. Direito Civil - Direito das coisas, p. 39-40.

${ }^{81}$ Silvio de Salvo Venosa. Código Civil Comentado Vol. XII - Coordenador Álvaro Villaça Azevedo, p. 36.

${ }^{82}$ Humberto Theodoro Junior. Posse e Propriedade, p. 4.

${ }^{83}$ Silvio de Salvo Venosa. Código Civil Comentado Vol. XII - Coordenador Álvaro Villaça Azevedo, p. 43.
} 
Maria Helena Diniz entende que a codificação civil seguiu as formulações de Ihering: "O nosso legislador andou bem em adotar a tese de Ihering, porque se não há propriedade sem posse, dar proteção a esta é proteger indiretamente aquela; se a propriedade é direito real, a posse também o é; se a posse for ofendida, ofende-se também o domínio, daí o motivo pelo qual se deve proteger a posse na defesa da propriedade" ${ }^{\Perp}$.

Para Silvio Rodrigues, “o Código Civil adotou a teoria de Ihering”,85.

Também na opinião de Marco Aurélio Bezerra de Melo ${ }^{86}$, o Direito brasileiro adotou a teoria objetiva de Ihering.

Nesse sentido completa Rosa, tendo o Código Civil mantido "praticamente a mesma orientação do anterior com respeito à posse. $\mathrm{O}$ artigo 1.196 tem redação semelhante à do dispositivo correspondente no Código Civil de 1916, eliminando, apenas, redundância terminológica" ${ }^{, 87}$.

Também a lição de Farias e Rosenvald ${ }^{88}$, "ao conceituar a posse da mesma forma que seu antecessor, o Código Civil de 2002 filia-se à teoria objetiva, repetindo a nítida concessão à teoria subjetiva no tocante à usucapião como modo aquisitivo da propriedade que demanda o animus domini de Savigny. Com efeito, predomina na definição da posse a concepção de Ihering. (...) Assim, pela letra do legislador, o possuidor é quem, em seu próprio nome, exterioriza alguma das faculdades da propriedade, seja ele proprietário ou não".

Desta forma, percebe-se que, ao adotar a teoria objetiva, não se furtou o legislador brasileiro de manter certas nuances próprias da teoria subjetiva em nossa codificação civil.

\footnotetext{
${ }^{84}$ Maria Helena Diniz. Curso de Direito Civil Brasileiro, Direito das Coisas, p. 52.

${ }^{85}$ Silvio Rodrigues. Direito das Coisas, p. 20.

${ }^{86}$ Marco Aurélio Bezerra de Melo. Direito das Coisas, p. 35.

${ }^{87}$ Pedro Henrique de Miranda Rosas. Direito Civil - Direito das coisas, p. 41.

${ }^{88}$ Cristiano Chaves de Farias; Nelson Rosenvald. Direitos reais, p. 33.
} 


\subsubsection{A POSIÇÃO DE SAVIGNY}

Para caracterizar a posse, defendeu em 1803 Friedrich Karl Von Savigny que seria necessário o animus, após realizar profundo estudo das fontes romanas, aos vinte e quatro anos de idade. Só quem possuísse com animus domini apresentaria verdadeiramente a posse. Outras situações não seriam protegidas, exceto pela posse derivada (para abranger o credor pignoratício, o precarista, e o depositário de coisa litigiosa) ${ }^{89}$.

Inicialmente, Savigny indica que o primeiro elemento distintivo da posse é a detenção de algo, de forma que ocorra a possibilidade de relação física da pessoa com a coisa, mas também que a relação das outras pessoas com a coisa esteja excluída. Esta detenção não seria uma relação jurídica, baseada na lei, uma vez que "como a propriedade consiste no poder legal de dispor livremente da coisa, excluindo todos os demais da possibilidade de usufruir da mesma, o exercício da propriedade ocorre mediante a detenção, a qual consiste portanto em um situação de fato, enquanto a propriedade é uma condição legal"90.

Salienta ainda Savigny que os romanos também identificavam na posse uma fonte de direito (um modo de aquisição da propriedade), por isso o autor traça contornos muito claros da posse que está interessado em estudar, aquela que importa à teoria da posse, ou seja, os direitos de posse (jus possessionis) e não os direitos originados da posse (jus possidendi), pois este último faria parte da teoria da propriedade ${ }^{91}$.

Dois aspectos (direitos) podem ser indicados como atinentes exclusivamente à posse, despidos de qualquer indício de propriedade: a usucapião (originada na Lei das XII Tábuas: quem quer que possua uma coisa por um ou dois anos se torna seu proprietário) e os interditos (considerando que a mera posse não seria uma relação legal, uma eventual turbação não seria uma infração; mas se uma turbação é infringida à força, ocorre de fato uma infração à lei, pois toda violência é condenável - e contra isso os romanos passaram a proporcionar um interdito).

\footnotetext{
${ }^{89}$ Carlos Roberto Gonçalves. Direito Civil Brasileiro, Direito das coisas, p. 48.

${ }^{90}$ Frédéric Charles de Savigny. Treatise on Possession - The jus possessionis of the civil law, p. 3

${ }^{91}$ Ibid., mesma página.
} 
A mera posse, independente de qualquer direito, se torna a origem da própria propriedade. Por isso, a posse seria considerada mero fato. Assim, a posse no Direito romano estava sempre e indissociavelmente ligada aos conceitos de usucapião ou aos interditos ${ }^{92}$.

Savigny afirma que geralmente todos acabam admitido que alguém está na posse de algo quando presente a faculdade, não apenas de dispor fisicamente da coisa, mas também de a defender contra toda ação exterior ${ }^{93}$. Nesse sentido, a posse é um fato que corresponde ao direito de propriedade.

Para Savigny, em sua origem a posse é mero fato; mas deste fato advém consequências. Portanto, posse é ao mesmo tempo fato (por natureza) e direito (em razão das consequências que produz), havendo uma verdadeira relação dupla, destacando que essa natureza dúplice é talvez, o aspecto mais importante relacionado à posse.

Em toda a aquisição de posse deve estar presente um ato físico (corpus ou factum) e também um ato volitivo (animus), devendo o factum ocorrer de forma a possibilitar o gozo exclusivo daquele que detém a posse sobre a coisa, ou seja, o exercício da propriedade sobre a coisa; e o ato de vontade deve abranger uma relação da pessoa com a coisa como se dono fosse. "O poder físico, desta forma, é o fato que deve existir em toda aquisição de posse, (...), corpus significa o evento externo, em contraposição ao ato interior (animus) $)^{, 94}$.

Em princípio, a vontade consiste em tratar a coisa como se pertencesse ao sujeito, configurando o animus domini, sendo esse ponto muito claro para o sujeito e suficiente para evitar que confunda essa vontade (animus domini) com outro sentimento consistente na convicção de ser realmente proprietário (opinio domini).

Savigny também distingue o animus possidendi que ocorre quando a posse é "alienada" (transferida) independentemente da propriedade a que estava associada, originando uma posse derivada (la possession dérivée), que não é mais animus domini, mas sim

\footnotetext{
${ }^{92}$ Frédéric Charles de Savigny. Treatise on Possession - The jus possessionis of the civil law, p. 17.

${ }^{93} \mathrm{Idem}$, Traité de la possession en droit romain, p. 6-7.

${ }^{94}$ Idem, Treatise on Possession - The jus possessionis of the civil law, p. 148.
} 
simplesmente o animus possidendi. Assim, sobre o animus possidendi, explica Savigny que o ato físico/corpóreo deve estar sempre acompanhado de um ato mental definitivo (animus), caso contrário não haverá posse ${ }^{95}$; deve estar presente a vontade da pessoa na sua relação com a coisa como se proprietário fosse.

Serpa Lopes $^{96}$ resume muito bem a teoria formulada por Savigny para descrever o fenômeno da posse perante o Direito romano: a teoria do animus indica e reserva "o primado ao elemento subjetivo - vontade - este mesmo elemento, é o que, para ele, transforma a detenção em posse". Assim, "a teoria de Savigny fundamentalmente apoia-se na conjugação desses dois elementos: o corpus e o animus. O corpus é um fato físico correspondente ao fato jurídico da propriedade, enquanto o animus possidendi representa a intenção de exercer o direito de propriedade ${ }^{97}$. (...) Daí a razão de se denominar a doutrina de Savigny como sendo subjetivista, por isso que, embora o corpus seja integrante do conceito de posse, todavia, o elemento decisivo na sua qualificação como posse assenta nesse animus sibi habendi".

Em conformidade com o ensinamento de Serpa Lopes, segundo a teoria subjetiva poder-seia encontrar quatro categorias de pessoas:

(a) possuidores (o proprietário, aquele que acredita ser, o ladrão e o invasor de um imóvel; nessa categoria todos são possuidores pela existência do animus domini).

(b) o detentor (com título ius in re, como o usufrutuário; nessa hipótese, não há posse, sendo o usufrutuário mero administrador; porém nesse caso há uma exceção criada no Direito romano, mediante a figura da quase-posse, o que garante a proteção interdital).

\footnotetext{
${ }^{95}$ Savigny ainda alerta para que se evite a confusão entre animus domini e opinio domini, uma vez que neste último caso há apenas uma convicção moral da parte em ser proprietária (Traité de la possession en droit romain, p. 177).

${ }^{96}$ Miguel Maria de Serpa Lopes. Curso de Direito Civil. Direito das coisas. Vol. VI, p. 110.

${ }^{97}$ Deve-se destacar que há duas maneiras de tal ânimo se manifestar, por parte de um detentor: tendo em vista o exercício do direito de propriedade de outrem (faltando o aninimus possidendi necessário para transformar a detenção em posse), ou o exercício em interesse próprio (nesse caso, caracterizando a posse, "porque o animus possidendi outra coisa não é senão o animus domini ou animus sibi habendi") (Serpa Lopes, p. 108-110).
} 
(c) o detentor por força de título contratual, como o locatário, não havendo posse e nem mesmo sua proteção.

(d) aquele que detém a coisa em nome de outro, como o mandatário; nessa categoria não há posse, pela ausência do animus domini; pelo contrário, há detenção da coisa alienum nomine.

Reforçando esse entendimento, na forma muito bem elaborada por Dubertret, para Savigny a intenção que fomenta a vontade do possuidor é o animus domini, ou seja, a intenção de se comportar como dono. Assim, o elemento determinante da teoria subjetiva é a intenção do possuidor de se comportar como proprietário. Como resultado, o detentor não seria um possuidor. O corpus, enquanto apreensão material ou física do bem, para Savigny é um elemento secundário e insuficiente ${ }^{98}$.

Afirma Savigny que a posse não alcança um lugar entre os direitos, uma vez que não é somente um direito, mas sim um direito pessoal, abrangendo a possibilidade de invocação dos interditos possessórios, razão pela qual a posse apresenta uma semelhança muito grande com um direito propriamente dito, exigindo regras específicas sobre as formas de sua aquisição e perda ${ }^{99}$.

Em conclusão, para essa teoria a vontade é considerada imprescindível para se deter materialmente uma coisa: sem nenhuma participação da vontade, não haverá posse ${ }^{100}$.

Martin Wolff aparentemente se filia e concorda com o estudo desenvolvido por Savigny, pois indica que a posse se caracteriza quando presentes o corpus possessionis (senhorio sobre a coisa) e o animus rem sibi habendi, ressalvando, tal como Savigny, que certas situações se equiparam tanto à posse verdadeira que como tal são tratadas, havendo a proteção possessória também ao detentor (como no caso da actio spolii do Direito

\footnotetext{
${ }^{98}$ Matthieu Dubertret. Negociabilité et possession, p. 296.

${ }^{99}$ Frédéric Charles de Savigny. Traité de la possession en droit romain, p. 40.

${ }^{100}$ Ibid., p. 586.
} 
canônico). Chega a mencionar Wolff que a doutrina de Ihering se insurgiu contra Savigny, "mas sem lograr desterrá-la"101.

Sobre a apropriação corporal da coisa, Ihering a identifica como a teoria subjetiva, então dominante, o corpus como a relação exterior da pessoa com a coisa, estabelecida pela apreensão (o poder físico ou a supremacia de fato da pessoa sobre a coisa). Mas afirma que este não era o conceito usado pelos romanos para designar a manifestação da vontade no ato de apreensão. E fulmina: "Esta teoria está absolutamente errada"102, pois é possível haver uma supremacia ou domínio da pessoa sobre coisas, sem que haja posse - citando o exemplo do poder do pai sobre o filho; apesar de haver um poder de fato nesse caso, o pai não detém a propriedade sobre o filho, e "onde a propriedade não é possível, também não será a posse". Isto porque "a posse não é o poder físico, mas a exteriorização da propriedade". Trataremos com maiores detalhes da teoria de Ihering no próximo item.

Em moderno estudo desenvolvido à luz da teoria subjetiva da posse, a autora portuguesa Ana Paula Costa e Silva busca equacionar a importância do animus, bem como também explicar a intenção não apenas por si só, como fenômeno mental interno (o que seria extremamente difícil, ou até mesmo impossível de detectar de forma indubitável), indicando que só se pode entender a intenção quando ela for exteriorizada, ou seja, pelos sinais que são emanados pelo possuidor na relação com a coisa ${ }^{103}$.

Nesse sentido, procurando dar concretude à intenção, explica a autora que a posse se revelará na ação que "seria expectável de um proprietário" ${ }^{104}$; ou seja, a pessoa está agindo mediante ações ou comportamentos que normalmente seriam tomados apenas pelo proprietário.

Desta forma, percebemos que a teoria subjetiva e seu criador manterão o mérito de ter iniciado o resgate do estudo da posse, para explicá-la sob a luz da experiência do Direito romano. Mas expressar a posse de forma subjetiva significa não superar a limitação de

\footnotetext{
${ }^{101}$ Martin Wolff. Tratado de Derecho Civil, Tomo Terceiro - Derecho de Cosas, V. I, p. 23.

102 Já ao final de seu texto citado, Ihering menciona que a obra de Savigy não conservará valor para a ciência, "não representará mais que um interesse histórico". Rudolf von Jhering. Ouevres Choisies, Possession. Théorie simplifiée et mise à la portée de tout le monde, p. 263.

${ }^{103}$ Paula Costa e Silva. Posse ou Posses?, p. 28.

${ }^{104}$ Ibid., p. 30.
} 
outras pessoas, que não o proprietário, também poderem exercer de fato uma das funções da coisa, permanecendo a grande dificuldade (e ponto fraco) da teoria subjetiva, pois sempre será tarefa altamente complexa determinar em cada caso exatamente o comportamento do proprietário, para então ser possível afirmar se se está diante do fenômeno da posse ou não.

Pode o comportamento variar de pessoa para pessoa, mesmo um proprietário não necessariamente se portará ou terá exatamente os mesmos cuidados com a coisa, se comparado a outro. Assim, como esperar apenas um comportamento uniforme e padronizado, relacionado à propriedade das coisas, diante da multiplicidade e da mutabilidade de costumes da sociedade atual? Exemplificando o que nos parece tarefa quase impossível: para uma pessoa, apenas o proprietário poderia sublinhar passagens de um livro, mas para outra esse comportamento poderia ser perfeitamente aceitável por aquele que não é proprietário; dito de outro modo, há quem entenda perfeitamente possível e tolerável que um não proprietário sublinhe o livro de outra pessoa. Relegar à subjetividade o aferimento da posse é sempre estar sujeito a visões distintas para o mesmo fenômeno.

É por tais razões que, na prática do Direito, a teoria subjetiva se mostra inferior.

Nesse sentido, também afirma Tepedino que "a verdade é que, mesmo com a contração da teoria da posse derivada, Savigny não resolveu por completo a questão, já que não conferiu proteção possessória a outras figuras relevantes como o locatário e o usufrutuário, que, naturalmente, não detêm a coisa com a intenção de ser proprietário". Essa deficiência prática somente foi superada com a teoria de Ihering, que guarda esse mérito até hoje: "tanto o detentor como o possuidor têm vontade de ter a coisa para sim (por Iherig chamada de affectio tenendi), embora o ordenamento jurídico estabeleça em que casos não haverá proteção legal, desnaturando-se a posse em mera detenção"105.

\footnotetext{
${ }^{105}$ Gustavo Tepedino. Comentários ao Código Civil, Direito das Coisas, V. 14, Coordenador Antônio Junqueira de Azevedo, p. 62-63.
} 
Por outro lado, apresentando um importante contraponto, registram as professoras Giselda e Silmara ${ }^{106}$ passagem interessante com a indicação da lição sempre pertinente de Rui Geraldo Camargo Viana, em palestra proferida no I Seminário sobre o Novo Código Civil Brasileiro, promovido pela Câmara dos Deputados Federal, em 4 de junho de 2002, refutando que o nosso Código prescindiu do elemento volitivo na configuração da posse, nos seguintes termos: "Não há posse sem vontade. Mera detenção não é posse, quem não tem intenção de possuir não é possuidor. (...) Dizer que a posse não tem elemento subjetivo é tolice. No fundo, as divergências entre Von Ihering e Savigny são mais aparentes que reais".

Assim, em conclusão, percebe-se que a vontade é elemento da posse, e dela não se dissociará; porém, como passaremos a discorrer a seguir, mais bem sucedido foi Ihering, ao encontrar também nas fontes romanas justificativa teórica para afirmar que a vontade está compreendida no corpus, não sendo elemento essencial para caracterizar a posse.

\subsubsection{A POSIÇÃO DE IHERING}

Rudolf Von Ihering, que fora aluno de Savigny na Faculdade de Direito de Berlim, iniciou no ano de 1868 a publicar seus estudos confrontando e atacando o trabalho de Savigny ${ }^{107}$.

O principal aspecto defendido por Ihering consistia no fato de o animus já estar inserido no corpus, sendo mais importante que o animus o caráter de exteriorização da propriedade, ou seja, bastaria a conduta de dono, a forma como o proprietário age exercendo a função econômica do bem, ou, em outras palavras, a ação do sujeito sobre a coisa tendo em vista a função econômica, para caracterizar a posse. Importante haver a vontade de agir como habitualmente faz o dono (com affectio tenendi, independentemente do animus domini), dispensando-se a análise subjetiva da intenção. A posse é a exteriorização da propriedade, a visibilidade do domínio, cumulada com o uso econômico da coisa. "Ela é protegida, em resumo, porque representa a forma como o domínio se manifesta" ${ }^{108}$.

\footnotetext{
${ }^{106}$ Giselda Maria Fernandes Novaes Hironaka, Silmara Juny de Abreu Chinelato. Revista da Faculdade de Direito da Universidade de São Paulo, Propriedade e Posse: uma releitura dos ancestrais institutos, p. 83. ${ }^{107}$ José Carlos Moreira Alves. Posse, V. I. Evolução Histórica, p. 217.

${ }^{108}$ Carlos Roberto Gonçalves. Direito Civil Brasileiro, Direito das coisas, p. 51.
} 
Relata Ravail que à época em que triunfava a teoria de Savigny, começaram a surgir críticos cada vez mais certos das falhas da teoria subjetiva, especialmente um “jurisconsulto de grande envergadura, profundamente versado no conhecimento das leis romanas, chamado Ihering, que criou uma crítica metódica e rigorosa, além de juridicamente profunda, fundada nos textos e legislação romana, seu espírito e sua razão. A crítica de Ihering fundava-se no fato de o ensinamento de Savigny ser puramente abstrato e dissociado da função básica de propiciar satisfação às necessidades sociais"109.

Ihering muito lutou contra a teoria subjetiva, que chamava de teoria reinante: "segundo a teoria reinante, essa vontade [animus] deve tender a possuir a coisa como da maneira de uma coisa própria (animus domini). Na falta de semelhante vontade, é a ela que em certos casos, segundo parece, deve-se conceituar como posse, não no sentido jurídico, mas no natural (detenção, mera posse). Essa doutrina é falsa: a verdadeira aplicação da diferença está, não na natureza particular da vontade de possuir, e sim na disposição legal, que, segundo a diversidade da relação (causa possessionis), faz nascer ora a posse ora a detenção possessória”. Ihering também se opõe à teoria segundo a qual o corpus corresponde ao poder físico de fato sobre a coisa ${ }^{110}$.

Para dar suporte à sua discordância, Ihering lembra as coisas que não podem, por suas características ficar sob a guarda efetiva do possuidor, pois seu destino econômico exige que estejam desprotegidas a descoberto, como as ervas, o feno, a palha no campo, a madeira cortada no bosque, o combustível, o carvão ao lado da mina, as pedras na pedreira, os materiais de construção ao pé da obra, indicando este autor que "em todos esses casos não há poder físico sobre a coisa: a segurança do possuidor não se funda na situação 'de excluir a ação das pessoas estranhas', uma vez que a lei proíbe essa ação: descansa não sobre um obstáculo físico, mas sim jurídico"111.

\footnotetext{
${ }^{109}$ Pierre-Julien Ravail. De L'object de la possession. Essai sur le droit romain, l'ancien droit français et le droit actuel, p. 4.

${ }^{110}$ Rudolf Von Ihering. Teoria Simplificada da Posse, p. 60-63.

${ }^{111}$ E é a partir deste fato que Ihering percebe a necessidade de proteção da posse: "Por que a posse se protege pelo Direito? Não é certamente para dar ao possuidor a alta satisfação de ter o poder físico sobre uma coisa, a não ser para tornar possível o uso econômico da mesma em relação a suas necessidades. (...) Não se recolhem em sua casa os materiais de construção, etc., não se depositam em pleno campo o dinheiro, os móveis, as coisas preciosas, etc. Cada qual sabe o que deve fazer com essas coisas, segundo sua diversidade, e este
} 
Assim, a necessidade da existência de poder físico exercido pelo possuidor dependerá das características e dos atributos da coisa, notadamente, como indicou Ihering, da forma como seu uso econômico se dará. Defende, portanto, Ihering que os adeptos da teoria romanista (como Savigny) erram ao imaginar que para toda posse haverá necessidade de estar presente o poder físico sobre a coisa quando, na verdade, este não é um valor absoluto, e sim relativo, na medida em que "o ponto de vista do poder físico não tem uma significação para a posse, porque esse poder seria apenas exigido em certo casos para a sua utilização econômica".

Em outras palavras, existiriam coisas que poderiam ser economicamente usadas ou exploradas prescindindo-se do poder físico sobre elas. Assim, haveria coisas que se devem guardar com relação de poder físico, e outras livres ou abertas, sobre as quais tal poder físico não é necessário. Então, podemos entender da construção de Ihering que a relação de posse nem sempre é meramente a relação da pessoa com a coisa exercida como poder físico, mas sim a posse deve ser entendida como uma relação finalística entre a pessoa e a coisa (relação conforme o fim econômico).

O exemplo usado por Ihering, para diferenciar situações em que existe posse de outras em que esta não está presente, consiste nos cavalos amarrados por um laço em um bosque (ou também matérias de construção ao lado de uma obra) e uma cigarreira com cigarros ao lado de um solar em construção. Para este autor, aquele que avistasse tais cavalos amarrados certamente saberia que estão sob a posse de alguém, pois assim foram deixados por alguém; diferentemente dos cigarros, pois ninguém os deixaria jogados no chão propositalmente - foram então perdidos. No primeiro caso, há posse; no segundo, não. Isto porque a posse deve ser avaliada segundo o destino econômico que a coisa está cumprindo $^{112}$.

aspecto normal da relação do proprietário com a coisa constitui a posse" (Rudolf Von Ihering. Teoria Simplificada da Posse, p. 65).

112 "Os cavalos presos no laço e a madeira ao pé da obra se encontram colocados na posição conforme o seu destino econômico: a cigarreira, não; é contra o seu destino econômico estar por terra em pleno campo. Isto basta ao homem simples para proceder com uma correção perfeita, sem que tenha a menor ideia da noção de posse" (p. 70). 
Assim, a detenção é equivalente à posse, em seu aspecto material, de forma que somente excepcionalmente (quando a lei determinar) se privará o detentor da proteção possessória $^{113}$.

Ademais, continua Dubertret, Jhering conferiu maior importância ao corpus, sendo o animus para ele apenas o animus tenendi, pouco importando a que título o possuidor exerce seu poder sobre a coisa; por conseguinte, o detentor poderia ser um possuidor como qualquer outro. Por tal razão, em vista desta teoria, seria possível afirmar que qualquer pessoa que exercendo um poder sobre a coisa indica, mesmo que de forma implicíta, a vontade de exercer o direito correspondente ao poder sobre a coisa. O animus aparece apenas secundariamente, uma vez que fica subentendido pelo corpus, que passa a ser elemento determinante dessa teoria denominada objetiva. A posse se resume definitivamente ao corpus ${ }^{114}$.

Apresenta o próprio Ihering que a teoria então dominante de Savigny indicava que a relação possessória depende da vontade daquele que detém a coisa, tendo ele a vontade de possuir por si mesmo (animus rem SIBI habendi) ou da maneira de um proprietário (animus DOMINI). Nesses casos, haveria posse; em todos os outros, havendo vontade de possuir por outro, haverá detenção. Neste último caso estariam compreendidos o locatário e o comodatário, havendo neles apenas o animus possessionis. Ressalta Ihering que Savigny errava também ao acreditar que o Direito romano não aceita a forma da posse sem que estive presente o animus domini - esses casos para Savigny eram apenas posse derivada, na qual a coisa está com a pessoa sem o animus possidendi, estando essa vontade dirigida apenas para ter a coisa e não para possuí-la como proprietário (e se o Direito romano admite a existência de posse em casos tais que não apresentam o animus necessário, será apenas em caráter anômalo e excepcional) ${ }^{115}$.

Ihering, por sua teoria objetiva, é frontalmente contrário a essa redução das hipóteses possessórias: as duas condições que geralmente são necessárias para a existência da posse, o animus e o corpus, apresentam-se unidos, e portanto sempre há relação possessória,

\footnotetext{
${ }^{113}$ Miguel Maria de Serpa Lopes. Curso de Direito Civil. Direito das coisas. Vol. VI, p. 114.

${ }^{114}$ Matthieu Dubertret. Negociabilité et possession, p. 296.

${ }^{115}$ Rudolf von Jhering. Études Complémentaires de L'Esprit du Droit Romain, Tomo III - Du Rôle de la Volonté dans la Possession, p. 5-6.
} 
exceto se um dispositivo legal determine excepcionalmente que há detenção. Vale dizer, com o caráter volitivo restritivo resultar-se-á na posse quase que excepcionalmente, enquanto na interpretação objetiva a posse será a regra e a detenção a exceção, por depender de lei que a indique.

Portanto, para demonstrar a existência da posse basta estabelecer a existência exterior da relação possessória,o corpus, o qual por si só já implica o animus.

Por outro lado, ressaltava que a posse seria impossível sem a vontade, ou ainda, nas palavras de Ihering "o próprio contato corpóreo imediato, sem a intenção e a vontade, não constitui a posse ${ }^{116}$. (...) Uma noção de posse que não seja fundada na vontade é completamente irreal".

Para demonstrar a diferença entre a posse e a detenção nas duas teorias, Ihering lançou mão das seguintes formulas:

$\mathrm{x}=$ posse

$\mathrm{y}=$ detenção

$\mathrm{c}=$ corpus

$\mathrm{a}=$ ânimo de deter (affectio tenendi)

$\alpha=$ elemento adicional que se junta ao ânimo de deter (animus domini)

Então, na teoria subjetiva temos a seguinte representação matemática:

$$
\begin{gathered}
x=c+a+\alpha \\
y=c+a
\end{gathered}
$$

Na teoria objetiva, a representação matemática é a seguinte:

\footnotetext{
${ }^{116}$ Lembrando ainda Ihering que por essa razão o Direito romano não conheceu a posse em pessoas desprovidas da vontade ou incapazes. Rudolf von Jhering. Études Complémentaires de L'Esprit du Droit Romain, Tomo III - Du Rôle de la Volonté dans la Possession, p. 18-19.
} 


$$
\begin{gathered}
x=c+a \\
y=c+a-N
\end{gathered}
$$

$\mathrm{N}$ corresponde ao fator negativo legal pelo qual é retirado o caráter possessório em certas relações, que faz a relação "descer um degrau” e passar de posse a detenção, em caráter excepcional. Logo, a posse será regra, e não exceção ${ }^{117}$.

O possuidor é aquele que, mesmo não sendo o proprietário, se comporta como tal; aquele que mesmo que não possua ou creia possuir como um proprietário, entende ter a coisa como um proprietário, à maneira de um proprietário. Para Ihering, essa disposição resolve o problema da vontade na posse que seria "a pretensão à posição de proprietário, ou com a intenção de ter a coisa, à maneira de um proprietário, de forma permanente, autônoma e independente de terceiros" 118 .

Para a demonstração da posse, a simples exteriorização da relação possessória é suficiente, sem que seja necessário haver prova da vontade. A posse aparente implica a vontade de possuir. Ihering traça um paralelo com as relações obrigacionais: para as relações de venda e de locação, não é exigido um animus vendendi ou um animus locandi, o mesmo se aplicando ao animus possidendi quando se tratar da posse. E arremata indicando que "a vontade que apresenta imensa importância para a doutrina dominante [subjetiva], não se manifestava nunca na aplicação cotidiana do direito, uma vez que a vontade possessória coincide com a posse aparente, da mesma forma que a vontade de vender e de alugar coincide com a venda e a locação aparentes”. Em conclusão, Ihering assevera que a teoria subjetiva, ao opor a posse e a detenção, se torna falsa ${ }^{119}$.

Em outro aspecto a teoria objetiva se diferencia da subjetiva: na garantia à posse. Para Ihering, a relação possessória surge em cada caso concreto de forma distinta, não havendo uma fórmula geral irrestritamente aplicável, pois cada bem cumpre a sua função de uma forma. Adicionalmente, com relação aos terceiros que se veem diante de tal fenômeno,

\footnotetext{
${ }^{117}$ Rudolf von Jhering. Études Complémentaires de L'Esprit du Droit Romain, Tomo III - Du Rôle de la Volonté dans la Possession, p. 46. Ressalta-se a utilização dos símbolos e terminologia originais mencionados por Ihering.

${ }^{118}$ Ibid., p. 73.

${ }^{119}$ Ibid., p. 404.
} 
ocorre um reconhecimento dessa relação, o caráter de sua visibilidade ordinária que lhe confere essa segurança, havendo um elemento jurídico-legal e moral que leva as demais pessoas a adotar comportamento de respeito àquela relação, deixando-a livre de interferência $^{120}$.

Em conclusão, Ihering afirmava que a segurança da posse está exclusivamente nas garantias morais e jurídicas, e não na poder físico ${ }^{121}$ - assim, a posse é garantida por esse elemento jurídico-moral e não físico (a exemplo das decisões romanas no sentido de que (a) o caçador não perde a posse quando o animal escapa ao laço; (b) permanece a garantia à posse dos terrenos distantes (os saltus aestivi et hiberni ${ }^{122}$ ), dos escravos e dos animais ausentes). Por tal razão é que a posse não pode ser explicada pelo poder físico, uma vez que o Direito romano admitiu a posse em vários casos que não havia vigilância pessoal sobre a coisa, ou seja, sem custódia. Assim, "a segurança da posse descansa essencialmente na proteção jurídica concedida à relação de direito do homem sobre a coisa”, e não no poder físico.

Disto decorre também, diante de tantos exemplos encontrados por Ihering de objetos e coisas que são "deixados" sem um poder efetivo de vigilância pelos seus possuidores, ${ }^{123}$ que a única relação possessória possível é considerar a posse a exteriorização da propriedade (sendo elas unidas mutuamente pela utilidade econômica), de forma que "o proprietário não tem que recear que o direito o abandone enquanto usar da coisa de um modo conforme o seu destino" 124 , segundo as características e diversidades de cada coisa. Por isso, para Ihering, a existência da posse é uma questão de pura experiência cotidiana, da vida ordinária.

\footnotetext{
${ }^{120}$ Rudolf von Ihering. Fundamentos dos Interditos Possessórios, p. 160. Outro exemplo usado pelo autor: "Se eu passo perto do laço armado por outrem no bosque sem me apoderar do pássaro nele preso, o motivo que me retém não é de natureza física, mas puramente moral: é o respeito à propriedade alheia".

${ }^{121}$ Rudolf von Ihering. Fundamentos dos Interditos Possessórios, p. 163.

122 Consistem em pastos usados apenas durante um período do ano; se durante o inverno, saltus hiberni, se durante o verão, saltus aestivi. Tais áreas eram consideradas posse contínua da pessoa que as utilizava durante a estação apropriada. Conforme Encyclopedic Dictionary of Roman Law, Volume 43, parte 2, 1953, p. 689.

${ }^{123}$ Nesse sentido, a descoberto e sem vigilância, o caçador deixa no bosque suas armas e laço; o lenhador deixa a lenha que cortou; o pescador a pesca e redes; as pedras na pedreira; o mineiro deixa a hulha na mina; o arquiteto os materiais de construção na obra; os navios nos portos durante o inverno (p. 165) - sugere autor que se deve deixar de lado a idéia fixa de que a posse seria a detenção corporal da coisa.

${ }^{124}$ Rudolf von Ihering. Fundamentos dos Interditos Possessórios, p. 166.
} 
No que tange à diferença entre as duas teorias, com relação ao corpus (relação interna da posse), se para Savigny, na interpretação que fazia do Direito romano, a posse era uma detenção corporal da coisa, implicando na sua custódia, na interpretação de Ihering havia um paralelismos da posse com a propriedade, e eram encontrados tantos exemplos de continuidade da posse mesmo quando ocorria o "abandono" da coisa ou ausência de custódia, que a posse era determinada em função da característica (diversidade) da coisa, havendo posse mesmo quando não houvesse poder, custódia ou vigilância sobre a coisa.

Após o desenvolvimento das aludidas teorias da posse, relata Gonçalves o surgimento das teorias sociológicas deste instituto, na Itália, França e Espanha, no início do século XX, dando ênfase ao caráter econômico e à função social da posse, com Silvio Perozzi (que em 1906 desenvolveu a teoria social da posse e indicou que a posse prescinde do corpus e animus, e resulta de um "fator social" que evoca a consequente abstenção dos terceiros com relação à exclusividade dessa posse; quem tem a posse torna aparente essa situação e todos, espontaneamente se abstêm de importuná-la; uma questão de costume e civilização), Raymond Saleilles (que desenvolveu a teoria da apropriação econômica, pregando a independência da posse, pois há uma consciência social que dá valor econômico a este fenômeno, havendo posse "onde há relação de fato suficiente para estabelecer a independência econômica do possuidor" ${ }^{125}$, baseada na observação dos fatos sociais); e por sua vez, António Hernández Gil, que defendeu em sua teoria a conjugação da necessidade e do trabalho humano com a posse, com ênfase na função social portanto. A posse tem um papel-função perante o Estado, o de proporcionar igualdade na distribuição dos recursos. Trataremos das teorias sociais da posse a seguir.

\footnotetext{
${ }^{125}$ Carlos Roberto Gonçalves. Direito Civil Brasileiro, Direito das coisas, p. 57.
} 


\subsection{POSSE: FATO OU DIREITO?}

Desenvolvidos os principais aspectos das teorias que buscaram explicação para o fenômeno possessório, passaremos à análise da questão da natureza jurídica da posse.

Ruggiero indica que as fontes são conflitantes, ora mencionando possessio aniem plurimum facti habet ora quia possessio non tantum corporis sed et juris est. Savigny defendia ser ao mesmo tempo um fato e um direito (nas suas consequências); para Ihering, era um direito, por ser um interesse juridicamente protegido. Ainda nos dias de hoje, discute a doutrina se, sendo a posse um direito, seria um direito pessoal (oponível apenas contra o agente do esbulho; de caráter personalíssimo) ou real (oponível contra todos), ou ainda uma terceira possibilidade - um direito real sui generis, ${ }^{126}$.

Indica Giancoli que há uma controvérsia estabelecida sobre a natureza jurídica da posse, pois "ora ela é vista como um fato, ora como um direito; ora atribuem-lhe bivalência, aludindo que é simultaneamente um fato e um direito" ${ }^{127}$.

Para Ravail, a posse não consiste unicamente no poder ou na apreensão física sobre uma coisa, mas sim no conjunto dos fatos exteriores, aparentes e visíveis, que variam de acordo com as características e a natureza da coisa, sua forma de utilização econômica e habitual em determinada época, ou seja, um feixe de relações da pessoa com a coisa, mediante os quais se manifesta o direito de propriedade. O pouvoir physique não basta para explicar a posse; devem-se levar em conta os atos que seriam normal e ordinariamente exercidos por um proprietário em relação a uma coisa de sua propriedade, em conformidade com suas características e destinação (para o autor, resumido na expressão encontrada no Código de Justiniano, omnia ut dominum gerere). Por isso, a posse seria a exteriorização e a visibilidade da propriedade ${ }^{128}$.

\footnotetext{
${ }^{126}$ Roberto de Ruggiero. Instituições de Direito Civil. Vol. II, p. 763.

${ }^{127}$ Brunno Pandori Giancoli. Direito Civil, p. 364.

${ }^{128}$ Pierre-Julien Ravail. De L'object de la possession. Essai sur le droit romain, l'ancien droit français et le droit actuel, p 12. O autor vai mais longe, apregoando que, em verdade, nunca será uma coisa (material ou não) o objeto da posse, mas sim e sempre um direito à coisa que será o objeto da posse: "a posse tem por objeto, em sendo a exteriorização da propriedade, o próprio direito, e não a coisa que se encontra submissa [a esse direito]" (p. 15).
} 
Indica Biondo Biondi que a posse é apenas uma relação de mero fato. E por consequência, a usucapião seria apenas admissível para as coisas efetivamente possuídas ${ }^{129}$.

Inicialmente, Manuel Rodrigues indica que "a posse é apenas uma condição de fato necessária para se defender o direito real de que ela faz supor a existência, por uma forma mais rápida, ou para evitar a violência". Chega a afirmar Rodrigues que a "própria natureza da posse é contrária a ideia do direto", pois a posse é muitas vezes resultado de dolo, violência, injustiça ${ }^{130}$.

A posse é um fato, mas um fato jurídico por virtude dos efeitos que a lei lhe atribui apenas isso seria inadmissível para Rodrigues, pois para este renomado doutrinador português a posse é um direito, porque a lei reveste a posse, por a proteger, de todos os caracteres de um direito, havendo nela todos os elementos do direito subjetivo: (a) um interesse; (b) um poder; e (c) uma garantia jurídica. Assim, para Rodrigues, "a posse reveste portanto todos os caracteres de um direito. Ela é na verdade um poder que prossegue um interesse garantido pela lei",131.

Martin Wolff ensina que a posse é um direito provisório sobre a coisa (diferentemente dos direitos reais, que são definitivos), pois a pose é defendida apenas provisoriamente - por essa razão, indica Wolff, a posse tradicionalmente não é incluída entre os direitos reais em sentido técnico, o registro imobiliário não é acessível à posse, e a posse de um não proprietário não constitui um gravame sobre a coisa, da mesma forma que a transmissão da posse também não implica na disposição da coisa ${ }^{132}$.

Ribas apresenta o mesmo sentido de Savigny, indicando a posse, enquanto considerada em si mesma, como um fato, mas também como um direito, se consideradas as suas consequências $^{133}$.

\footnotetext{
${ }^{129}$ Biondo Biondi. Los Bienes, p. 169.

${ }^{130}$ Manuel Rodrigues. A posse. Estudo de Direito Civil Português, p. 34.

${ }^{131}$ Ibid., p. 35-38.

${ }^{132}$ Martin Wolff. Tratado de Derecho Civil, Tomo Terceiro - Derecho de Cosas, V. I, p. 20.

${ }^{133}$ Antonio Joaquim Ribas. Da posse e das ações possessórias, p. 21.
} 
Gustavo Tepedino tece também comentários sobre a posse, ainda nos primeiros momentos de vigência do então novo Código, indicando que a posse "é definida como um exercício de fato. Independentemente, pois, de título, o simples exercício de uma das faculdades inerentes ao domínio já se constitui em posse, um direito autônomo, com ações próprias, independente em relação à propriedade". Assim, em resumo, Tepedino indica que "a posse, no Novo Código, está posta como mero exercício de fato de alguma das faculdades inerentes ao domínio, sem o domínio e mesmo contra o domínio" ${ }^{134}$.

No ensinamento de Chamoun, a posse no Direito clássico era um estado de fato, enquanto no Direito justinianeo é um direito (a posse conserva-se apenas com a "mantença do animus") $^{135}$.

Para Joel Dias Figueira Jr., a posse consiste em situação de fato resultante de relação potestativa protegida juridicamente; tutelada de forma independente do direito da qual deriva, as ações possessórias protegem o fato que é a posse; assim, a natureza da posse é fática-potestativa, não sendo um direito, mas um fato-potestade (e o fato é socioeconômico), sendo essa carga de poder que gera seus efeitos, ou seja, "um poder de ingerência e disponibilidade socioeconômica exercida pelo titular da relação fática sobre um bem da vida em toda a sua inteireza e pureza sem qualquer comprometimento com o mundo jurídico (em especial, os direitos reais), existindo por si mesma"136. Essa visão da posse nos parece fortemente processualista, não sendo possível deixar de lado toda a carga valorativa de direito a ela inerente.

A posse pode ainda ser entendida como um direito pessoal. Para aqueles que entendem ser a posse um direito pessoal, isto decorre do fato de ser ela um direito tutelado juridicamente pelo interdito possessório, que resguarda a pessoa contra a violência ou ameaça de violência praticada, gerando a obrigação ex delicto, sendo normalmente pessoais os direitos decorrentes de obrigações ${ }^{137}$.

\footnotetext{
${ }^{134}$ Gustavo José Mendes Tepedino. Os Direitos Reais no Novo Código Civil. Revista da EMERJ - Escola da Magistratura do Estado do Rio de Janeiro, p. 170-171.

${ }^{135}$ Ebert Chamoun. Instituições de Direito Romano, 220.

${ }^{136}$ Joel Dias Figueira Jr. Posse e ações possessórias, p. 127-128.

${ }^{137}$ Edmundo Pereira Lins. Estudos Jurídicos na Cátedra e na Judicatura. Ensaio sobre a Posse (direito romano e civil), p. 215.
} 
Afirma Serpa Lopes não ter dúvida ser a posse um direito, e não uma simples relação de fato $^{138}$, seguindo, portanto, a linha adotada por Ihering (e também Laurent, Molitor, Ferrada, Tartufari, Lafaille, Salvat e outros). Continua Serpa Lopes que para Savigny a posse era ao mesmo tempo fato e direito (relação obrigacional ex delicto), ou seja, refletia a proteção da pessoa do possuir contra toda violência que poderia ser praticada contra sua posse. Outros autores, como Molitor, inclinaram-se à natureza pessoal da posse, especialmente pela ausência da sequela, para depois chegar à conclusão de conceituar a posse como um direito real-pessoal. Lembra o autor que, para Ihering, sendo a posse um direito, tal direito só pode pertencer à categoria dos direitos reais.

Serpa Lopes indica também que, quando da elaboração do Código de 1916, Clóvis Beviláqua esclareceu que seguiria a inserção da posse no do capítulo do direito das coisas, seguindo o entendimento de Ihering, mas dissentiu do aludido mestre quanto à ordem, pois a inclui antes da propriedade, e não depois (como sugerido por Ihering), justificando especialmente que a posse pode levar à propriedade, nos casos de usucapião.

Limongi França chega a uma conclusão dupla: “A posse considerada em si mesma é um fato material, diverso do fato ou do ato jurídico, porque está divorciada das características primordiais destes dois últimos. (...) Não obstante seja um simples fato, a posse é hábil a gerar direitos e é desse ponto de vista que interessa ao ordenamento (...) Em conclusão: a posse é fato e é direito" 139 .

Salienta Álvaro Antônio Sagulo Borges de Aquino que, para Savigny a posse é ao mesmo tempo um fato e um direito, pois "considerada em si mesmo, seria um fato; considerada nos efeitos que gera, como a usucapião e o direito de invocar os interditos possessórios, ela se coloca como um direito" ${ }^{140}$. Já para a teoria objetiva de Ihering, indica ainda o mesmo autor, a posse "é um interesse juridicamente protegido, sendo, portanto, um direito".

Para Ascensão, a posse não pode ser apenas entendida como um fato, pois pode subsistir mesmo dissociada da situação de fato subjacente (como em consequência de sucessão).

\footnotetext{
${ }^{138}$ Miguel Maria de Serpa Lopes. Curso de Direito Civil. Direito das coisas. Vol. VI, p. 90-92.

${ }^{139}$ R. Limongi França. A Posse no Código Civil (noções fundamentais), p. 20.

140 Álvaro Antônio Sagulo Borges de Aquino. A posse e seus efeitos, p. 26.
} 
Também não acredita que posse seja simultaneamente um fato e um direito (como Savigny). Assim, "posse é uma realidade jurídica, que tem como pressuposto uma realidade, ou uma situação de fato, mas que na sua existência, tem autonomia em relação a ela", tendo em vista que na "origem de toda a situação jurídica posse há sempre uma atuação de fato, que é inclusivamente uma atuação material. A tutela jurídica é sempre subsequentemente à verificação de uma dada realidade de fato" ${ }^{141}$. Assim, a origem da posse é uma situação de fato, mas Ascensão não encontra um termo específico para denominar tal situação (não seria correto usar termos como "posse-fato", "possessio naturalis", “detenção”): “com isso concluímos que não há designação específica. Temos que falar sempre em 'situação de fato que está na base da posse'. É incomodo, mas é correto".

No estudo de Moreira Alves sobre o Direito romano, manifesta o autor que "é certo que muitos autores (assim, por exemplo, Ihering e Lenz) consideraram a posse um direito embora diferente do direito de propriedade -, e a enquadram, em geral, entre os direitos reais". No entanto, o eminente autor indicar ser mais preciso o entendimento demonstrado por Bonfante no sentido de que a posse é um fato, e não um direito, lembrando ainda que os jurisconsultos romanos do período clássico tinham noção que a posse era fato ${ }^{142}$.

Para Venosa, posse é estado de aparência juridicamente relevante ${ }^{143}$, um estado de fato protegido juridicamente. Por isso, julga inócua a discussão sobre a natureza da posse, se fato ou direito, pois o direito protege a posse como aparência, desaparecendo "a razão prática, que tanto incomoda os doutrinadores, em qualificar a posse como simples fato ou como direito".

Sobre a natureza da posse, António Menezes Cordeiro discute as mais variadas vertentes, que admitiram encontrar na posse: (a) uma ação, (b) uma relação jurídica, (c) um fato jurídico, (d) um interesse legítimo, (e) o exercício de um direito subjetivo, (f) um direito pessoal, (g) um direito real, (h) um direito diverso. Indica Menezes Cordeiro concordância com a visão de Savigny sobre a natureza da posse, podendo ser ora um fato, ora um direito,

\footnotetext{
${ }^{141}$ José de Oliveira Ascensão. Direito das Coisas - reais, p. 80-81.

${ }^{142}$ José Carlos Moreira Alves. Direito Romano. V. I, p. 324.

${ }^{143}$ Silvio de Salvo Venosa. Direitos Reais, p. 26.
} 
“conforme o modo por que seja tomada. Seria um fato jurídico quando presente o controle material da coisa que recebe a tutela ou efeitos jurídicos. Entre tais efeitos, se encontram por exemplo as defesas possessórias. O conjunto de tais efeitos forma a situação jurídica denominada posse, que surge nesse contexto como um direito subjetivo"144.

Em sendo um direito subjetivo, prefere o autor não caracterizá-la como um direito real, ao menos como direito real de gozo, por "uma razão histórico-cultural simples e definitiva: porque no Direito romano, elas não davam azo a actiones in rem" $" 145$. E conclui "a posse, enquanto posição tutelada - hoje: enquanto direito subjetivo - dispunha da tutela interdital, em termos que as recepções do Direito Romano mantiveram vivos e atuantes. Não se tratava de actiones in rem. Tanto basta para que, hoje, a posse, sendo embora um instituto de Direitos Reais, não seja verdadeiro direito real de gozo. Será, quando muito, um direito de gozo diferenciado".

$\mathrm{Na}$ doutrina espanhola, no tocante à natureza jurídica da posse, as opiniões sempre se dividiram quanto a ser considerada a posse um simples fato, um direito subjetivo ou, ainda, um direito real ou não. No Direito clássico romano, era considerada fato, passando no Direito pós-clássico a tender para um direito. A discussão foi mantida com os glosadores, ora pendendo para um lado, ora para outro.

Lembra Díez-Picazo ${ }^{146}$ que Ihering defendeu (contrariamente a Savigny) ser a posse um direto, pois se trataria de um interesse juridicamente protegido, sendo um direito subjetivo, tutelado pelo ordenamento jurídico. Até a sexta edição de sua obra Tratado da Posse, Savigny defendia ser a posse um fato, mas a partir daí considerou-a como direito em razão das consequências legais que dela derivam.

A solução estaria em conciliar as duas correstes, para o autor, seguido o ensinamento de Messineo, sabendo que a posse nasce como uma relação de fato, mas de imediato se converte em relação de direito, quando passa subitamente a produzir efeitos jurídicos, toda vez que um possuidor é admitido a continuar possuindo, por força de direito.

\footnotetext{
${ }^{144}$ António Menezes Cordeiro. A Posse: perspectivas dogmáticas actuais, p. 163.

145 Ibid., p. 164.

${ }^{146}$ Luis Díez-Picazo. Fundamentos del Derecho Civil Patrimonial III - las relaciones jurídico-reales, p 393.
} 
Então, para a melhor doutrina espanhola, a posse nasce uma coisa e se transforma em outra; ao nascer, do fato, já traz em si o gérmen do direito que imediatamente se torna.

Como o bóson de Riggs, que surge para conferir massa às matérias, mas tem duração efêmera e sua existência quase não é sentida. Utilizando-nos dessa comparação com a física, a posse é o bóson de Riggs do Direito; a partícula de Deus do Direito.

Atualmente, a maioria dos juristas entende a posse como direito. Para Orlando, como a posse é exercida sem intermediário (relação direta e imediata da pessoa com a coisa), e de forma erga omnes (oponível a terceiros), e tendo em vista que tais características são encontradas somente nos direitos reais, é, portando, direito real (e jus possessionis também teria natureza real) ${ }^{147}$.

Assim, diante do exposto, está estabelecido o caráter de direito que acompanha a posse. Mas seria direito pessoal, obrigacional, ou real?

A contribuição de Gustavo Tepedino ao tema reflete a situação sui generis que a posse evoca, contendo aspectos de direito pessoal e de direito real; mas não chega a considerar a característica da realidade, pois "a posse constitui-se como situação de fato, suscita a proteção jurídica como direito autônomo de seu titular e se exerce direta e imediatamente sobre a coisa, embora, por sua origem fática, faltam-lhe alguns atributos próprios dos direitos reais" $" 148$.

$\mathrm{Na}$ opinião de Aquino, a posse tem tratamento idêntico ao de um direito real, pois "o Código Civil, ao tratar da posse no Livro III, referente ao Direito das Coisas, deu à posse tratamento de autêntico direito real, com todas as suas características", não sem lembrar que de tal visão não comunga Silvio Rodrigues, por ela não constar da lista taxativa de direitos reais prevista em nosso Código ${ }^{149}$.

\footnotetext{
${ }^{147}$ Orlando Gomes. Direitos Reais (atualização Luis Edson Fachin), p. 39.

${ }^{148}$ Gustavo Tepedino. Comentários ao Código Civil, Direito das Coisas, V. 14, Coordenador Antônio Junqueira de Azevedo, p. 49.

149 Álvaro Antônio Sagulo Borges de Aquino. A posse e seus efeitos, p. 27.
} 
Indicam Washington de Barros e Carlos Alberto Dabus Maluf que a disposição do Código Civil de 1916, não sem escapar de criticas mais atuais, considera a posse um "fato socioeconômico potestativo, e não como um direito real" ${ }^{150}$.

Lembra Moreira Alves que o próprio Clóvis Beviláqua, nas "observações para esclarecimento do Código Civil Brasileiro", indicou que a noção de posse contida no Projeto de Código foi extraída da doutrina de Ihering, acrescentando as palavras de Clóvis “aceito a noção que Ihering nos dá, a posse é, por certo, direito; mas reconheçamos que um direito de natureza especial. Antes conviria dizer, é a manifestação de um direito real”. Posteriormente, o projeto sofreu diversas alterações nas várias comissões e grupos de estudo pelos quais tramitou, tendo sido, em um deles, introduzidos muitos elementos do Código Civil português de 1867, seguidor da teoria subjetiva, resultando no Código que passou a vigorar a partir de $1^{\circ}$ de janeiro de 1917 , e nele, no tocante à posse, na opinião de Moreira Alves, "convivem, na desarmonia natural dos inconciliáveis, princípios da posse romana, da posse canônica e da gewere" ${ }^{151}$.

Joel Dias Figueira Jr. indica o mais forte argumento pelo qual teóricos defendiam a impossibilidade de a posse ser entendida como direito real: "do artigo $676^{152}$, extrai-se o preceito de que, por ato entre vivos, os direitos reais sobre imóveis só se adquirem depois do registro (conforme art. 168 da Lei de Registros Públicos - inscrição e transcrição). Nem o Código, nem a Lei de Registros Públicos determinam ou descortinam a possibilidade de registro imobiliário da posse, ficando, assim, excluída qualquer hipótese de seu ingresso no mundo jurídico".

Também a lição de Farias e Rosenvald ${ }^{153}$, após considerar ser a posse um direito subjetivo, dotado de natureza peculiar, indica que não poderia ser apresentado como um direito real, especialmente (a) pela impossibilidade de se tornar oponível a terceiros, pois a posse não foi expressamente elencada como direito real, quer pelo rol numerus clausus do art. 1.255 do Código Civil, quer em legislação esparsa; (b) pela irregistrabilidade da posse no

\footnotetext{
${ }^{150}$ Washington de Barros e Carlos Alberto Dabus Maluf. Curso de Direito Civil, Direito das coisas, p. 14.

${ }^{151}$ José Carlos Moreira Alves. Posse, V. I. Evolução Histórica, p. 265-269.

152 Este artigo corresponde ao art. 1.227 do Código Civil de 2002: "Os direitos reais sobre imóveis constituídos ou transmitidos por atos entre vivos só se adquirem depois da transcrição, ou da inscrição, no Registro de Imóveis".

${ }^{153}$ Cristiano Chaves de Farias; Nelson Rosenvald. Direitos reais, p. 35-36.
} 
Cartório de Registro de Imóveis, o que lhe negaria o caráter absoluto de direito real, por não haver previsão de registro da posse na Lei de Registros Públicos, privando-lhe do caráter de oponível erga omnes, bem como da sequela, preferência e publicidade, "uma vez que os direitos reais imobiliários apenas nascem com o registro"; (c) por não haver as formalidades da propriedade, sua aquisição e transmissão somente poderiam ser provadas por testemunhas; (d) por força do artigo 1.212 do Código Civil, que impede a reintegração na posse quando o poder de fato encontra-se com terceiro de boa-fé que ignorava a origem ilícita da posse; e (e) por estar dissociada do capítulo atinente aos direitos reais no Código Civil.

Nesse sentido, pela falta de registro, não poderia ser a posse considerada oponível contra todos (erga omnes), com possibilidade de sequela. "A sua oponibilidade não é contra todos, pois encontra limitações quando se trata de terceiro com justo título e boa-fé ou legítimo titular de domínio ou propriedade. Não existe uma indeterminação absoluta do sujeito passivo, mas sim relativa, limitada" ${ }^{154}$.

Esta também é a posição de Silvio Rodrigues. No ensinamento deste mestre, "direitos Reais são apenas os enumerados pela lei - o art. 1.225 do Código Civil determina serem direitos reais a propriedade, a superfície, as servidões, o uso, a habitação, o direito do promitente comprador do imóvel, o penhor, a hipoteca e a anticrese. Portanto, o legislador limita o número dos direitos reais". A numeração não seria, portanto, exemplificativa, mas sim taxativa (numerus clausus). De acordo com outras opiniões igualmente balizadas, como as de Washington e Pontes de Miranda, podem as partes estabelecer outros direitos reais, desde que não contrários aos princípios de ordem pública e aos bons costumes. Todavia, para Silvio Rodrigues, tal entendimento não merece acolhida, pois o direito real é um espécie de direito que vem munido de algumas características importantes, tais como a oponibilidade erga omnes e a sequela, de modo que a sua constituição não pode ficar à disposição da livre vontade do indivíduo. Nesse sentido, dispõe Silvio Rodrigues que o principal argumento é que os direitos reais, por força do artigo 1.227 do Código Civil, devem necessariamente ser inscritos na matrícula, no registro imobiliário: “(...) a constituição de direitos reais sobre imóveis (...) está condicionada ao seu Registro no

\footnotetext{
${ }^{154}$ Joel Dias Figueira Jr. Posse e ações possessórias, p. 127-128.
} 
Cartório de Registro de Imóveis". Se as partes criarem um novo direito real, "o oficial não encontrara na lei permissão para fazer tal registro, nem livro adequado para assentá-lo"155.

Também Marcus Vinicius Rios Gonçalves ${ }^{156}$ indica a natureza jurídica como um direito pessoal, "embora com peculiaridades que a distingam de outros direitos pessoais". Baseiase também nas seguintes razões:

(a) a posse não seria oponível erga omnes, faltando à ela o caráter absoluto dos direitos reais, pois (a.i) a posse cede à propriedade, pela via reivindicatória; (a.ii) o art. 1.212 do Código Civil retira a possibilidade de recuperar a posse (sequela) de terceiros de boa-fé que não saibam que a coisa foi esbulhada, sendo um direito de sequela restrito, que cede à boa-fé, "o que se justifica pelo fato de que não se dá à posse a mesma espécie de publicidade que é dada aos direitos reais, ao menos no que se refere aos bens imóveis".

(b) o legislador processual civil tornou expressa a desnecessidade de outorga uxória "no polo ativo e de litisconsórcio necessário dos cônjuges no polo passivo, nas ações possessórias", o que as descaracterizaria enquanto ações reais.

Por isso, conclui o autor, "não sendo absoluta, e não trazendo a seu titular a possibilidade de opô-la a toda a coletividade, não há como considerar a posse como um direito real”.

Acrescenta ainda Darcy Bessone ${ }^{157}$ que "em suma, não há oponibilidade do direito do possuidor a todas as demais pessoas, até mesmo porque, no sistema do nosso Direito positivo, tal eficácia erga omnes dependeria da inserção de algum título no Registro de Imóveis, para que ele pudesse ser oposto às alienações ou onerações posteriores, isto é, a atos jurídicos ou contratos que, não houvesse a oponibilidade, não poderiam afetar o direito real titulado e registrado. No tocante à posse, simples estado de fato, não titulado nem registrado, seria inconcebível tal oponibilidade”.

\footnotetext{
${ }^{155}$ Silvio Rodrigues. Direito das Coisas, p. 8-10.

${ }^{156}$ Marcus Vinicius Rios Gonçalves. Dos Vícios da Posse, p. 7.

${ }^{157}$ Darcy Bessone. Da posse, p. 17.
} 
Ainda Moreira Alves, em sua espetacular e monumental obra sobre a posse, relata o desânimo dos estudiosos e doutrinadores para enquadrar a posse em qualquer das categorias jurídicas da dogmática moderna, em razão das peculiaridades que a posse apresenta - e limitam-se a ressaltar que a posse é uma figura especialíssima, e desta forma, sui generis, e completa: "em verdade, no direito moderno, a posse é um instituto jurídico sui generis" ${ }^{158}$. Por essa razão, aquele mestre indica ser a "posse um instituto jurídico, ainda que imperfeitamente acabado, o que determina que ela seja explicada com a aproximação a situações jurídicas, por ser aparência destas: é o como se fosse, independentemente de se saber se é ou não".

Todavia, em nosso entendimento tal concepção (adotada, entre outros, por Silvio Rodrigues, Marcus Vinicius Rios Gonçalves, Cristiano Chaves de Farias, Nelson Rosenvald e Joel Dias Figueira Jr., Darcy Bessone, entre outros) não mais prevalece, conforme veremos a seguir, especialmente diante da importante alteração legislativa observada.

Para Serpa Lopes, “dada a posição da posse no nosso Código Civil, não constitui ela um obstáculo a que se qualifique esse instituto como direito real" ${ }^{159}$.

Senise Lisboa, por sua vez, classifica a posse como um direito real, sobre o próprio bem, identificada como a posse ad usucapionem ${ }^{160}$.

Nesse sentido, Manuel Rodrigues manifesta sua opinião: "parece-nos que a posse deve ser considerada como um direito real"; porque a posse é um poder direto e imediato sobre a coisa e seu titular tem a faculdade de exigir de todos os indivíduos uma abstenção que lhe permita exercer os elementos constitutivos do direito que exterioriza: “dentro de um ano o

\footnotetext{
158 José Carlos Moreira Alves. Posse - estudo dogmático. Vol. II, p. 122. Em verdade, afirma também Moreira Alves concordância com a posição então desenvolvida por Hernandez Gil, porém também por ele abandonada mais tarde, por passar a entender ser a posse um direito, no sentido de que a posse "seria uma estrutura que não se transformou totalmente numa instituição jurídica, uma vez que a efetividade jurídica continua se apoiando na realidade social" (p. 124).

${ }^{159}$ Miguel Maria de Serpa Lopes. Curso de Direito Civil. Direito das coisas. Vol. VI, p. 93.

${ }^{160}$ Roberto Senise Lisboa. Manual de Direito Civil, p. 43.
} 
possuidor tem o direito de se reintegrar na sua posse, qualquer que seja o indivíduo que possua o seu prédio e o título que o possui",161.

De forma geral, a tendência da doutrina, e dos Códigos modernos, é considerar a posse um direito. Esclarece Caio Mario que "na verdade perdeu hoje importância o debate, resolvendo-se como dizer que, nascendo a posse de uma relação de fato, converte-se de pronto numa relação jurídica" "162. Assim, "é um direito real, com todas as suas características"

Acredita Pugliese ser a posse direito real, ter natureza de direito real, pois é "a natureza jurídica da posse, o fato existente que incide sobre a coisa, conjugado com o interesse simultâneo, do exercício do direito outorgado em razão do fato que o originou. Trata-se de Direito Real, que exercido sobre o bem, o acompanha, envolvendo-o" 164 .

Como um simples fato, com a doutrina de Pothier e dos antigos romanistas (inclusive a doutrina de Savigny até a $6^{\mathrm{a}}$ edição de sua obra). A posse como um direito, com Ihering, por ser um interesse tutelado juridicamente, pois reúne todas as características de um direito subjetivo. Outros ainda pregam o duplo caráter da posse, como Savigny a partir da a $6^{\text {a }}$ edição de sua obra Tratado da Posse, considera que a posse em si mesma seria um fato, mas que por haver consequências legais derivadas desse fato, torna-se também um direito. Assim, a posse entra para o mundo do Direito não apenas em razão dos seus efeitos, mas também por sua própria natureza e por ser causa determinante de tais efeitos - essa posição, chamada de "conciliadora e muito razoável” por Castan Tobeñas, está sendo valorizada pela doutrina civilista. Para Savigny, corresponderia a um direito obrigacional, mas afirma Castan Tobeñas que a posição mais aceitável e generalizada hoje indica ser um direito real, por representar um relação direta da pessoa com a coisa, um direito real de natureza particular, por ser objeto de uma proteção meramente provisória, correspondente à natureza do direito ${ }^{165}$.

\footnotetext{
${ }^{161}$ Manuel Rodrigues. A posse. Estudo de Direito Civil Português, p. 39-40.

${ }^{162}$ Caio Mario da Silva Pereira. Instituições de Direito Civil - direitos reais, Vol. IV, p. 21.

163 Lembra Caio Mario, ainda, a diferenciação que faz Wolff, qualificando a posse como direito real provisório, para diferenciá-la da propriedade (direito real definitivo).

${ }^{164}$ Roberto J. Pugliese. Summa da Posse - direito, ação e legislação. Vol. I, p. 71.

165 Jose Castan Tobeñas. Derecho Civil Español, Comun y Foral, p. 661-663.
} 
Para Penco, a posse consiste em verdadeiro direito real, em razão das características que lhe são próprias: "um poder imediato sobre a coisa cumulado com o direito de ser reintegrado ou mantido nessa condição ante qualquer ataque”. No entanto, ressalva que seria um direito real diferente dos demais, como a própria Lei Hipotecária de 1944 indica, como um fato de transcendência real, pois atualmente não é passível de inscrição no Registro Imobiliário, mas que, para o autor, não prejudica de modo algum sua natureza real. Indica que nesse sentido também se coloca a maioria da doutrina espanhola e também a melhor doutrina europeia, se bem que "com a particularidade de lhe atribuir uma natureza provisória, claudicante e transitória". Em síntese, apresenta Penco a seguinte natureza para a posse: (a) é um direito (b) é um direito real; e (c) se trata de um direito real de gozo imediato que conta com uma proteção provisória; daí ser um direito real provisório ou transitório $^{166}$.

Por outro lado, Guillermo G. Valdecasas indica ser a posse um poder de fato sobre uma coisa; a posse consiste do direito a esse poder. A posse é, antes de tudo, um fato, mas um fato ao qual o ordenamento jurídico atribui importantes efeitos jurídicos (como a proteção possessória ou a usucapião, entendida como a possibilidade de se converter em direito definitivo em razão do transcurso do tempo). Tais consequências jurídicas, que emanam e transcendem do fato da posse, fazem dela concomitantemente um direito subjetivo (jus possessionis), inferior à propriedade e demais direitos reais, pois pode sucumbir frente a eles; e por ser um direito provisório (só apresenta também uma defesa provisória, enquanto não surge um direito melhor), contrasta com os direitos reais definitivos ${ }^{167}$.

No entanto, apesar de ser um poder de fato sobre a coisa, não necessariamente precisa ser concreta e imediatamente exercido "para que exista um poder de fato sobre a coisa. (...) Basta que a pessoa se encontre em uma determinada relação objetiva com a coisa, de forma que para a opinião comum das demais pessoas, apareça como um poder de fato sobre a mesma. Esta relação há que apresentar certa estabilidade, um mero contato material, ou uma atuação fugaz e passageira não implicarão na posse”. Concorda, pois,

\footnotetext{
${ }^{166}$ Angel Acedo Penco. Derechos Reales y derecho inmobiliario registral, p. 47.

${ }^{167}$ Guillermo G. Valdecasas. La posesión, p. 1-2.
} 
com Ihering que estão intimamente entrelaçados o animus e o corpus, como "a relação que há entre a palavra e o pensamento" 168 .

Pela indicação de Tartière, percebe-se que a posse na Argentina, diferentemente da Espanha, não alcançou prestígio suficiente para alçá-la ao Registro de Imóveis.

Entre os direitos reais, inclui apenas o domínio, o usufruto, o uso e a habitação, as servidões, a hipoteca, a anticrese, os direitos reais atinentes à propriedade horizontal, os direitos de aquisição ou gravame sobre unidades de urbanizações privadas (bairros privados ou fechados, clubes de campo, condomínio, bairros de chácaras) e a superfície; e entre os diretos pessoais, as locações, o boleto de compra e venda e o direito de opção ${ }^{169}$.

Savigny indicava ser a posse um direito obrigacional, por supor que sua proteção representava a defesa da personalidade atacada, nascendo de obrigação ex delito ${ }^{170}$. Mas para Diez-Picazo a posição de ser um direito real é mais aceitável, por implicar uma relação imediata entre a pessoa e a coisa. Consiste, portanto, em um direito real, de natureza particular, por ser objeto de uma proteção meramente provisória; ou, nas palavras de Ferrara, um direito real provisório e de energia limitada.

Isso porque, em comparação à constância dos outros direitos reais, a posse tem caráter inegavelmente provisório - e para o autor essa é a razão pela qual o Código Civil alemão não incluiu tecnicamente a posse entre os direitos reais. A consequência é que o registro imobiliário para a posse é, então, inalcançável. Nesse sentido, a posse em si não pode ser considerada um gravame sobre a coisa, nem a transferência da posse implica a transferência da propriedade do bem ${ }^{171}$.

Para Valdecasasa, o Código Civil espanhol, em seu artigo 438, parte final, indica ser a posse um fato, mas ao mesmo tempo um direito ${ }^{172}$.

\footnotetext{
${ }^{168}$ Guillermo G. Valdecasas. La posesión, p. 10.

169 Gabriel de Reina Tartière. Principios Registrales. Estúdio Del derecho registral inmobiliario argentino, p. 257-262.

${ }^{170}$ Luis Díez-Picazo. Fundamentos del Derecho Civil Patrimonial III - las relaciones jurídico-reales, p 634.

171 Ibid., p 635.

${ }^{172}$ Guillermo G. Valdecasas. La posesión, p. 9.
} 
Indica Castan Tobeñas que a posse está incluída entre os direitos reais, na categoria de direitos reais propriamente ditos ou sobre coisas corpóreas, como um direito real de proteção provisória consiste na posse ${ }^{173}$.

Ademais, lembra ainda Silvio Rodrigues que muitos negam ter a posse a natureza de um direito. A posse é um "mero" estado de fato, que a lei protege em atenção à propriedade (sendo a posse manifestação exterior da propriedade). Sua conclusão é, portanto, no sentido de que "não se pode considerar a posse um direito real porque ela não figura na enumeração taxativa do art. 1.225 do Código Civil, e, como vimos, aquela regra é taxativa, não exemplificativa, tratando-se, ali, de numerus clausus. Esse é o meu ponto de vista" ${ }^{174}$.

Frente a essa questão, Maria Helena Diniz ressalta a existência de três correntes doutrinárias, asseverando cada uma delas que: (i) a posse é um fato; (ii) a posse é um fato e um direito (Savigny e outros) - em si mesma é um fato, mas quanto aos efeitos, é um direito (pois leva à usucapião e aos interditos); e (iii) a posse é um direito (Ihering e outros) - interesse juridicamente protegido, condição para se explorar economicamente o bem, seria a posse a instituição jurídica tendente à proteção do direito de propriedade, pertencendo ao âmbito do direito das coisas, entre os direitos reais.

Nesse sentido, a autora adverte que "a grande maioria de nossos civilistas reconhece a posse como um direito, havendo divergência de opiniões no que concerne a sua natureza real ou pessoal" 175 .

Na balizada opinião de Carlos Alberto Bittar, confere-se à posse defesa jurídica própria, a qual, em si, representa direito autônomo, com essencialidade e aproveitamento econômico próprios. Por isso, “(...) revestida dos caracteres próprios à espécie, a posse é direito real, mostrando-se, como os demais, oponível erga omnes, e incidindo sobre objeto determinado, material ou imaterial, conforme o caso" $" 176$.

\footnotetext{
173 Jose Castan Tobeñas. Derecho Civil Español, Comun y Foral, p. 146.

${ }^{174}$ Silvio Rodrigues. Direito das Coisas, p. 21.

${ }^{175}$ Maria Helena Diniz. Curso de Direito Civil Brasileiro, Direito das Coisas, p. 51.

${ }^{176}$ Carlos Alberto Bittar. Direitos Reais, p. 33.
} 
Entende Maria Helena Diniz que, “(...) a posse é um direito real, posto que é a visibilidade ou desdobramento da propriedade. Pode-se aplicar o principio de que o acessório segue o principal, sendo a propriedade o principal e a posse, o acessório, já que não há propriedade sem a posse. Nada mais objetivo do que integrar a posse na mesma categoria jurídica da propriedade, dando ao possuidor a tutela jurídica" ${ }^{177}$.

Lembra Edilson Pereira Nobre Junior que "a lei 10.406/02 novamente deixou em aberto a questão relativa à natureza jurídica da posse, mostrando-se silente em enveredar pela sua natureza de direito real. É que, ao enumerar de forma taxativa, os institutos que qualifica como tal não incluíra aquela"178.

Para Maria Helena Diniz, contudo, é possível identificar na posse todos os caracteres do direito real, tais como: (a) seu exercício direto, sem intermediário; (b) sua oponibilidade erga omnes; e (c) sua incidência em objeto obrigatoriamente determinado.

Conclui então Maria Helena Diniz que “devido à posição da 'posse' na sistemática do nosso direito civil, não há, pois, nenhum obstáculo a sua qualificação como direito real”, lembrando ainda que Enneccerus, Kipp e Wolff qualificam a posse como 'direito real provisório', para distingui-la da propriedade, que seria 'direito real definitivo ${ }^{, 179}$.

Para José Alberto C. Vieira, a posse tem “(...) natureza de direito real (de gozo)”. "Portanto, o regime jurídico da posse respeita a posse exercida nos termos de um direito real de gozo, a sua inserção sistemática é a dos direitos reais de gozo ${ }^{180}$. A posse representa um ordenação de uma coisa corpórea a uma pessoa. Seria a posse "um direito real mais fraco ou enfraquecido"?

\footnotetext{
${ }^{177}$ Maria Helena Diniz. Curso de Direito Civil Brasileiro, Direito das Coisas, p. 52.

${ }^{178}$ Edilson Pereira Nobre Junior. A Posse e a Propriedade no Novo Código Civil, p. 3. Pela mesma razão, indica este autor que “(...) Com isso, mantém-se inalterada a convicção que exclui da incidência do art. 10, par 1, I, do CPC, as demandas possessórias". Nessa mesma linha, o entendimento de Silvio Rodrigues: "o elenco do art. 1.225 do Código Civil pode ser ampliado pelo próprio legislador, quando lhe parecer conveniente admitir outro direito real" (Direito das Coisas, p. 10).

${ }^{179}$ Maria Helena Diniz. Curso de Direito Civil Brasileiro, Direito das Coisas, p. 52.

${ }^{180}$ José Alberto C. Vieira. Direitos Reais, p 513.
} 
A posse é um direito "porquanto não só tem grande interesse econômico, por ser condição sine qua da utilização da propriedade, como ainda é protegido e por uma ação especial - os interditos possessórios" ${ }^{181}$.

Indica Ana Rita Vieira Albuquerque que Hernández Gil entendia estarmos diante de um processo de espiritualização da posse, entendendo-a como verdadeiro direito real ${ }^{182}$. Para Hernández Gil, a posse, conforme critério doutrinal generalizado, ou se integra aos direitos reais ou se correlaciona aos mesmos, porque as coisas são essenciais (elemento constante) aos direitos reais assim como à posse, e por tal razão se justifica a equiparação $^{183}$.

Para Ihering, seria um direito real: "Pour protéger le propriétaire comme possesseur, on devait protéger le possesseur lui-même d'une manière absolue. C'est ainsi que la possession est devenue un rapport juridique indépendant à côté et en dehors de la propriété, donc un droit sur la chose", ou, em outras palavras do criador da teoria objetiva, "para proteger o proprietário como possuidor, deve-se protegê-lo de maneira absoluta. É nesse sentido que a posse se tornou uma relação jurídica autônoma, ao lado e frente à propriedade, e portando um direito sobre coisa" ${ }^{\text {184 }}$.

Discutiu-se muito se a posse poderia ser um direito real e se a ação possessória apenas poderia ser impetrada especificamente contra o agente do esbulho, sendo uma ação pessoal, e não real, com força e alcance erga omnes. Edmundo Pereira Lins não concorda ser a posse um direito pessoal, acrescentando firmemente que "qualquer que seja a definição de direito real que adotemos é incontestável que a posse é um direito real". Reitera, referido autor que, "a posse é, pois, incontestavelmente, um direito real" ${ }^{185}$.

\footnotetext{
${ }^{181}$ Edmundo Pereira Lins. Estudos Jurídicos na Cátedra e na Judicatura. Ensaio sobre a Posse (direito romano e civil), p. 154.

${ }^{182}$ Ana Rita Vieira Albuquerque. Da função social da posse. p. 135.

${ }^{183}$ António Hernández Gil. La función social de la posesión (ensayo de teorización sociológico-jurídica), p. 115

${ }^{184}$ Rudolf von Jhering. L'esprit du droit romain dans les diverses phases de son développement, p. 350.

${ }^{185}$ Edmundo Pereira Lins. Estudos Jurídicos na Cátedra e na Judicatura. Ensaio sobre a Posse (direito romano e civil), p. 224.
} 
Não se pode deixar de reconhecer o caráter de direito à posse. Ela é a chave que dá acesso ao tesouro, nas palavras de Ihering - e a esse elemento o Direito confere proteção jurídica, de forma que está presente a condição necessária para o aparecimento ou reconhecimento de um direito. Para Ihering, caso a posse não fosse merecedora de proteção, certamente se restringiria a uma relação de fato com a coisa; mas, uma vez merecedora de proteção, a posse "apresenta a característica de uma relação jurídica, sinônimo de direito". Por ser uma relação imediata da pessoa com a coisa, a posse pertence ao direito das coisas. Dada a relação íntima entre posse e propriedade, menciona Ihering que a hipótese de a posse vir posicionada após o estudo da propriedade (considerada o principal eixo de todo o direito das coisas), seria assim uma instância de proteção e primeiros-socorros da propriedade, levando em consideração a importante facilitação de prova que a proteção da posse proporciona ao proprietário. Por tais razões, a posse se relaciona aos ditos direitos reais sobre coisa alheia, ou seja, os direitos revestidos da proteção absoluta (jura in re aliena), que se projetam sobre a coisa "não inteiramente, mas apenas em certos aspectos" e por isso Ihering se refere a ela como "desmembramento da propriedade" ${ }^{186}$.

Dubertret indica que a definição dos elementos constitutivos da posse foi objeto de intensas discussões ao final do século XIX entre Savigny e Jhering, sendo esta controvérsia concluída a favor do segundo; e que não apresenta grande interesse nos dias de hoje ${ }^{187}$.

Alega Lins, em resumo, para afastar qualquer dúvida de que posse seria direito real, e não pessoal $^{188}$ : (a) a interdição da violência não é o único fundamento das ações possessórias; (b) aos direitos reais por vezes também podem corresponder ações pessoais (como no caso das ações noxaes e furtivas que são pessoais; e (c) no uso moderno do Direito romano, os interditos podem ser intentados em oposição a qualquer terceiro, que contra a vontade do possuidor detenha a coisa em seu poder, e que não lhe queira restituir (resultado da ampliação da noção de vis ocorrida no Direito romano, com a perda de importância da menção à violência). A posse foi assim inserida entre os direitos reais em diversas

\footnotetext{
${ }^{186}$ Rudolf von Jhering. Ouevres Choisies, Possession. Théorie simplifiée et mise à la portée de tout le monde, $\mathrm{p} 238$.

${ }_{187}$ Matthieu Dubertret. Negociabilité et possession, p. 295.

${ }^{188}$ Edmundo Pereira Lins. Estudos Jurídicos na Cátedra e na Judicatura. Ensaio sobre a Posse (direito romano e civil), p. 219-225.
} 
legislações, tais como nos Códigos austríaco, japonês, alemão, suíço, argentino, e no Brasil pelo Esboço de Teixeira de Freitas, conforme lembrança feita por Lins.

Para Carlos Roberto Gonçalves, posse consiste em um direito, não propriamente um direito real, mas um direito sui generis, destacado das categorias de direitos reais ou pessoais, dada as suas particulares específicas e não compartilhadas com nenhum outro tipo de direto. Ampara-se em Beviláqua e Moreira Alves, no sentido de que a posse não é direto real, mas sim direto especial. Todavia, lembra Gonçalves que Ihering apregoava ser a posse um direito real ${ }^{189}$, pois sua sistemática mais se aproximava de tal tipologia de direito. Para Gonçalves, tal embasamento não bastaria, pois faltaria ainda o caráter erga omnes, o caráter absoluto característico dos direitos reais, não sendo a posse oponível erga omnes.

Percebemos a existência de diversas posições sobre a natureza jurídica da posse, aproximando-se as mais modernas do direito real. Porém a posse nunca foi tratada assim (como direito real) pela lei civil, nem no Código Civil de 1916, nem no Código Civil de 2002 e nem mesmo na Lei de Registros Públicos ${ }^{190}$.

Bastante interessante notar que no Anteprojeto de Código Civil de 1972, organizado e coordenado por Miguel Reale ${ }^{191}$, chegou ao ponto de elevar expressamente a posse à categoria de direitos reais, nos termos do artigo 1. 421:

Art. 1.421. A posse, nas condições estabelecidas por este Código, atribui ao possuidor o direito real a ela correspondente, por todo o tempo de sua duração.

Percebe-se que o nosso Código Civil de 2002 perdeu a oportunidade de alçar a posse à categoria dos direitos reais, ou mesmo de fazer qualquer menção nesse sentido, estando elencados no artigo 1.225 daquele diploma todos os direitos reais para efeitos da lei, que como vimos, envolve relação numerus clausus:

\footnotetext{
${ }^{189}$ Carlos Roberto Gonçalves. Direito Civil Brasileiro, Direito das coisas, p. 72-75.

${ }^{190}$ Ao menos até muito recentemente.

${ }^{191}$ Com a participação dos seguintes juristas: José Carlos Moreira Alves (Parte Geral), Agostinho de Arruda Alvim (Direito das Obrigações), Sylvio Marcondes (Direito de Empresa), Ebert Vianna Chamoun (Direito das Coisas), Clóvis do Couto e Silva (Direito de Família), Torquato Castro (Direito das Sucessões).
} 
Art. 1.225. São direitos reais:

I - a propriedade;

II - a superfície;

III - as servidões;

IV - o usufruto;

$\mathrm{V}-\mathrm{o}$ uso;

VI - a habitação;

VII - o direito do promitente comprador do imóvel;

VIII- o penhor;

IX - a hipoteca;

$\mathrm{X}-\mathrm{a}$ anticrese.

Para expressar a importância do registro imobiliário como fator constitutivo do respectivo direito real, expressa ainda, na sequência, o artigo 1.226 que "os direitos reais sobre imóveis constituídos, ou transmitidos por atos entre vivos, só se adquirem com o registro no Cartório de Registro de Imóveis dos referidos títulos (arts. 1.245 a 1.247), salvo os casos expressos neste código".

Desta forma, percebe-se que para a constituição de um direito real é essencial o seu registro na matrícula, no Cartório de Registro de Imóveis. Somente o registro conferirá ao respectivo título o efeito erga omnes e validade contra terceiros, em razão do princípio da presunção de publicidade decorrente do registro.

$\mathrm{Na}$ ausência do registro, o título terá apenas valor entre as partes, não sendo oponível contra terceiros, e por consequência não contará com o efeito indicado no aludido artigo 1.227 .

Assim, na vigência do Código Civil de 2002, a posse nunca seria considerada um direito real stricto sensu, pois não seria passível de assentamento no fólio real. Do ponto de vista do direito registrário, os direitos reais são apenas aqueles considerados como registráveis na matrícula do imóvel, junto ao respectivo Cartório de Registro de Imóveis. 
Para a convolação da posse em propriedade, era necessária uma específica ordem judicial, advinda da ação de usucapião, consistindo em modo originário de aquisição de propriedade, que resulta na abertura da matrícula ou inscrição do título/sentença, em caso de pré-existência de matrícula.

A mudança provocada pela legislação citada leva a alterações significativas, pois agora é possível, nos casos admitidos em lei, que a posse seja inscrita na matrícula do imóvel, tendo sido alterada a natureza da posse e afastadas as dúvidas quanto a esta consistir em direito real ou não.

Em que pese a forte tendência em visualizar-se a posse como direito real, não poderia ela ser entendida como tal, uma vez que não incluída pelo legislador no elenco do artigo 1.225 do Código Civil, nem mesmo no âmbito da Lei de Registros Públicos.

Nesse sentido, a posse somente poderia ser considerada como fato juridicamente protegido, por ser manifestação exterior (ou aspecto visível) da propriedade, a partir do qual reflete o direito análogo, que, por sua vez, quanto aos efeitos que gera, leva à possibilidade de se recorrer à usucapião e interditos.

Sabemos que os argumentos contrários a não se admitir a posse como verdadeiro direito real são especialmente: (i) a posse é fato protegido por lei, em razão da propriedade; e (ii) não está compreendida no rol do art. 1.225 do Código Civil, em vista do numerus clausus.

Em nossa visão, não parece suficiente indicar a complexidade inerente à posse, enquanto fenômeno socioeconômico lastreado no fato, ou sua especialidade ou autonomia para privar-lhe de seus atributos reais, especialmente agora com a edição das leis federais $\mathrm{n}^{\mathrm{o}}$ 11.977, de 7 de julho de 2009, e 12.424, de 16 de julho de 2011. Com tais leis, fica superada a escusa amparada no princípio do numerus clausus existentes tanto no Código de 1916 como no de 2002 (não estando a posse incluída no rol taxativo de direitos reais), pois acolhida que foi a posse ao registro imobiliário, assim como minimizado também o argumento da carência de efeito erga omnes, pois a posse passa a ser registrada, evidentemente valendo contra todos os terceiros, pela presunção de publicidade ínsita ao registro público imobiliário. 
De igual forma, fica superado o argumento de que contra terceiro possuidor de boa-fé a posse não seria oponível, pois com o registro da posse, nenhuma boa-fé resistirá, diante da presunção de publicidade conferida pelo registro, surgindo a sequela.

A posse já é um estágio preliminar da propriedade, tal como o compromisso de compra e venda, ambos já contendo o gérmen que desabrochará na propriedade com o passar do tempo, sendo suficiente esse fato para o legislador integrar o compromisso de venda e compra como direito real, conforme previsto no artigo 1.225, inciso VII (o direito do promitente comprador do imóvel) do Código Civil de 2002.

Acreditamos, pois, que o legislador de 2002 pecou por timidez ainda vinculada ao tradicional dissenso sobre a natureza da posse, pois já poderia ter dado um passo à frente e incluído a posse como direito real, tal como fazem as Leis $n^{\circ} 11.977$, de 7 de julho de 2009, e 12.424, de 16 de julho de 2011. Nesse sentido, considera-se muito mais evoluído o Anteprojeto de Código de 1972, organizado por Miguel Reale, tendo sido o professor e desembargador Ebert Vianna Chamoun o responsável pelo capítulo do direito das coisas, no qual já havia sido dado esse passo além, entendendo e classificando expressamente a posse como direito real.

Aliás, pode-se argumentar que a posse registrada apresenta força real e potencialidade de propriedade efetiva muito maiores que o próprio compromisso de compra e venda (já entendido expressamente como direito real pelo Código Civil de 2002), pois diferentemente deste, prescinde de qualquer anuência da parte contrária (na assinatura da escritura de compra e venda definitiva), ou mesmo da substituição da vontade desta parte contrária (na ação de adjudicação compulsória), pois já será convolada em propriedade efetiva pelo transcurso do tempo, mediante simples requerimento do interessado dirigido ao Oficial do Cartório de Registro de Imóveis ${ }^{192}$.

\footnotetext{
192 Aliás, tal procedimento vem em linha com a tendência de esvaziamento do Poder Judiciário de certas demandas que antes por este eram pacificadas, como (a) procedimento extrajudicial de retificação de registro, anteriormente necessitando das vias ordinárias (Lei $\mathrm{n}^{\circ}$ 10.931/2004); (b) a realização de inventário, partilha, separação consensual e divórcio consensual por escritura pública (via extrajudicial - Lei n 11.441/2007); (c) a mencionada Lei $n^{0} 11.481 / 2007$, sobre demarcação de imóveis da União para regularização fundiária de interesse social, também pela via administrativa; (d) o leilão extrajudicial para os imóveis objeto da alienação fiduciária, substituindo a tradicional hipoteca (Lei n ${ }^{\circ}$ 9.514/2007); (e) a usucapião administrativa trazida Lei
} 
Inaugura-se, então, um mundo das posses e não das propriedades, alçada e valorizada como efetivo direto real.

Em lugares já de desenvolvimento avançado, os conflitos possessórios cada vez mais se tornam aspecto do passado longínquo, uma vez que a posse já se tornou sedimentada e casos de conflito são mais raros.

Percebe-se agora que, contrariamente ao que ocorre no Brasil, em tais lugares a preocupação é minimizar a importância da posse, pois poderia ela gerar mais turbulência social: “A percepção histórica da propriedade fundada empiricamente na situação de fato está sendo rapidamente substituída por uma visão mais moderna da propriedade como um produto de um sistema governamental de titularidade informatizada"193.

$\mathrm{n}^{\mathrm{o}}$ 11.977/2009. Para mais detalhes sobre o procedimento extrajudicial para venda em hasta pública de imóvel alienado fiduciariamente, vide nossa dissertação de mestrado apresentada e aprovada na Faculdade de Direito da Universidade de São Paulo em maio de 2008, intitulada "A Alienação Fiduciária em Garantia e sua aplicação no mercado de financiamento imobiliário", tendo como orientador o Professor Doutor Álvaro Villaça Azevedo.

${ }^{193}$ Kevin Gray, Susan Francis Gray. Elements of Land Law, p. 150. 


\subsection{DISTINÇÃO ENTRE POSSE E PROPRIEDADE}

No Direito romano, "a posse representava um simples poder físico", como já indicava Ulpiano (DIG. 41, 2, 12, 1) ${ }^{194}$.

Assim, "a posse é o fato que permite e possibilita o exercício do direito de propriedade. Quem não tem a posse não pode utilizar-se da coisa. Essa a razão fundamental, entre outras, de ser protegido esse estado de aparência, como vimos. Sem proteção à posse estaria desprotegido o proprietário. Por conseguinte, prefere o ordenamento proteger sempre e com maior celeridade e eficácia o que detém aspecto externo da propriedade, a investigar em cada caso, e demoradamente, o título de proprietário e senhor". ${ }^{195}$

No ensinamento de Ihering, posse (enquanto exterioridade da propriedade) é o fenômeno que surge da relação particular que o homem exerce sobre a coisa que cumpre sua destinação econômica. Ou seja, é variável e se apresenta na realidade quanto ao seu aspecto exterior de diversas formas, de acordo com as características da coisa (exemplifica Ihering que certas coisas comumente ficam sob a vigilância pessoal ou real; outras ficam sem qualquer proteção ${ }^{196}$ ).

Para Perozzi ${ }^{197}$, é possível perceber em que ponto a posse diverge e em que ponto se assemelha à propriedade. São divergentes nos seguintes aspectos: a propriedade é um direito e a posse é um fato. A propriedade é constituída de uma liberdade jurídica de ação, que se considera existir por efeito da ordem de abstenção da coisa intimada pelo Estado a todos os outros cidadãos a favor de uma única pessoa; a posse é constituída de uma liberdade de fato de ação que existe a favor de uma pessoa por efeito do costume social de abstenção das coisas, que aparentemente já estão tomadas. A posse pode unir-se à propriedade, mas pode também desacompanhá-la. A posse é mais bem estudada quando

\footnotetext{
${ }^{194}$ Pedro Henrique de Miranda Rosa. Fontes Históricas da Teoria da Posse no Direito Civil Brasileiro, p. 21.

${ }^{195}$ Silvio de Salvo Venosa. Código Civil Comentado Vol. XII - Coordenador Álvaro Villaça Azevedo, p. 23.

${ }^{196}$ Rudolf von Ihering. Fundamentos dos Interditos Possessórios, p. 159. Ainda nesse mesmo sentido: "O lavrador deixa sua colheita em pleno campo, o arquiteto deixa em suas obras os materiais destinados à construção; porém ninguém trata assim seus objetos preciosos, seus móveis, etc, etc; todos os fecham em sua casa" (p. 160).

${ }^{197}$ Silvio Perozzi. Istituzioni di Diritto Romano, p. 83.
} 
separada da propriedade. Para Perozzi, o domínio depende de uma ordem de abstenção, enquanto a posse depende do fato da abstenção em si. A posse se parece com a propriedade na medida em que ela também é uma propriedade; mais precisamente, uma "propriedade social", um estado de liberdade de ação relacionado à coisa vigente por forças sociais.

Para Silvio de Salvo Venosa, "como a posse é considerada um poder de fato juridicamente protegido sobre a coisa, distingue-se do caráter da propriedade, que é direito, somente se adquirindo por título justo e de acordo com as formas instituídas no ordenamento". "Podemos afirmar que a posse constitui aspecto de propriedade do qual foram suprimidas alguma ou algumas de suas características"198 . Continua: "Pelo fato de o sistema permitir a aquisição da propriedade pelo usucapião, a posse assume relevo todo especial no ordenamento, merecendo maior proteção".

Senise Lisboa indica que a posse pode ser atribuída a quem é proprietário e a quem não o é, por isso a posse seria um minus em relação à propriedade ${ }^{199}$.

Para Dubertret, em matéria real a noção de posse apresenta laços com o direito à propriedade, um vez que a posse exterioriza o direito de propriedade do possuidor, e marca de maneira concreta aos olhos de terceiros a existência desse direito sobre o bem ${ }^{200}$.

Também na common law, o direito à posse consiste em um dos elementos que completam o direito à propriedade ${ }^{201}$. Wonnacott ensina que a palavra posse é usada atualmente no direito inglês para denotar duas situações principalmente ${ }^{202}$ :

(a) inicialmente, para descrever a relação entre a pessoa e um direito legal sobre um imóvel (legal estate in land), como a propriedade e a locação, entre outros. Assim, uma pessoa tem o direito de possuir o imóvel se anteriormente adquiriu algum título que inclua o uso e gozo imediato do bem; ou seja, que o título tiver sido acompanhado da imissão na posse (vested in possession). Uma pessoa detém a posse, ou está na posse, de um imóvel quando,

\footnotetext{
${ }^{198}$ Silvio de Salvo Venosa. Código Civil Comentado Vol. XII, p. 26.

${ }^{199}$ Roberto Senise Lisboa. Manual de Direito Civil, p. 37.

${ }^{200}$ Matthieu Dubertret. Negociabilité et possession, p. 294.

${ }^{201}$ Frederick Pollock e Robert Samuel Wright. An essay on possession in the common law, p. 145.

${ }^{202}$ Mark Wonnacott. Possession of land, p. 161.
} 
à exclusão de todos os demais, e de forma facilmente observável, está se beneficiando do imóvel.

(b) pode também ser usada a expressão posse como sinônimo de ocupação, quando a pessoa está fisicamente presente sobre a terra, fazendo uso tangível dela.

Lembramos que há dois textos romanos que expressam a separação entre posse e propriedade: Separata esse debet possessio a proprietate (D. 43, 17, 1, 2) e Nihil commune habet proprietas cum possessione (D. 41, 2, 1). Por isso, questiona Serpa Lopes ${ }^{203}$ como seria possível conciliar tais situações (a) a proximidade e similitude entre posse e propriedade e, ao mesmo tempo, (b) a separação absoluta entre elas? "A posse é destinada a proteger o domínio por isso se manifesta exteriormente semelhante ao domínio, em virtude de consistir no fato de alguém ter o exercício, pleno ou não, dos poderes inerentes ao domínio; essa defesa do domínio através do instituto possessório consiste em se prestar a repelir qualquer ataque desferido contra ele, sem outras indagações que não a própria situação de possuir a coisa visada pelo turbador; essa defesa possessória do domínio é de caráter temporário, por isso que se funda numa situação de puro fato. Em síntese: a posse está integrada ao domínio, como um elemento de sua própria defesa, mas essa função defensiva inerente à posse exige que se não confundam os dois institutos, pois, muitas vezes, a posse pode funcionar contrariamente ao domínio. É um resultado da precariedade de todas as instituições humanas". E conclui Serpa Lopes: "dessa separação nítida entre a posse e o domínio resulta que, no primeiro caso, surge o ius possessionis, no segundo o ius possidendi, isto é, o direito de posse e o direito de possuir".

Ebert Chamoun diferencia propriedade, consistente no direito de excluir da senhoria quem quer que seja, vale dizer, de fazer valê-la erga omnes; por outro lado a posse consiste em uma situação intermediária caracterizada pela simples possibilidade de exercício da senhoria, isto é, do conteúdo econômico da propriedade, e que merece, por motivos de interesse social, uma proteção jurídica específica ${ }^{204}$.

\footnotetext{
${ }^{203}$ Miguel Maria de Serpa Lopes. Curso de Direito Civil. Direito das coisas. Vol. VI, p. 95.

${ }^{204}$ Ebert Chamoun. Instituições de Direito Romano, p. 220.
} 
Para Serpa Lopes, a posse é um direito real diferente do direito de propriedade ${ }^{205}$.

Em conclusão do Ministro Teori Albino Zavascki, "posse e propriedade são institutos autônomos, tutelados sob enfoque de distintos princípios constitucionais. Harmônicos no plano normativo, os princípios do direito de propriedade e da função social das propriedades podem envolver-se em situações concretas de tensão, quando tracionam em direção oposta, a exigir solução de concordância prática que, fatalmente, importará a necessidade de limitação de um deles em benefício do outro, ou de ambos, em benefício comum do sistema. A Constituição, embora não assegure, explicitamente, um genérico 'direito à posse', inegavelmente tutela a posse quando necessário para atingir finalidades específicas, entre as quais a da concretização do princípio da função social"206 .

Gustavo Tepedino e Anderson Schereiber complementam sobre a autonomia da posse: "a posse, antes de ser um direito subjetivo, é a expressão fática do exercício de faculdades inerentes ao domínio. Daí ter sido tratada, na cultura jurídica romano-germânica, como uma vanguarda avançada do domínio, subserviente, portanto, ao direito de propriedade. $\mathrm{Na}$ medida em que esta expressão fática, erigida a direito substantivo, com suas ações autônomas e disciplina jurídica próprias, descola-se da proteção dominical, podendo ser exercida independentemente do domínio, sem o domínio ou contra o domínio, não há como se sustentar uma dogmática da posse vinculada ou acessória da propriedade"207.

Assim, se por um lado a posse cada vez mais ganha autonomia e alcança importância que rivaliza com a propriedade, naturalmente o fenômeno inverso também ocorre, com a consequente fragilização da propriedade, não a ponto de lhe subtrair a posição de instituto mais relevante do direito das coisas, pelo menos por hora, mas acreditamos que a tendência seja justamente essa: a posse com a atual musculatura que hoje já apresenta se cristalizará como o instituto-chave norteador da relação do homem com as coisas que necessita para seu desenvolvimento econômico. Acreditamos ainda que tal situação deva se estender no tempo.

\footnotetext{
${ }^{205}$ Miguel Maria de Serpa Lopes. Curso de Direito Civil. Direito das coisas. Vol. VI, p. 95.

206 Teori Albino Zavascki. A tutela da posse na Constituição e no Novo Código Civil. Revista Brasileira da Direito Constitucional, p. 61.

${ }^{207}$ Gustavo Tepedino, Anderson Schereiber. Questões Agrárias. Julgados comentados e pareceres, p. 130.
} 
Para isso, corrobora ao menos quatro fatores que identificamos:

(a) o surgimento e normalização da função social da propriedade;

(b) a estrutura maleável da posse, desprovida dos formalismos da propriedade, apta a se adaptar às vertentes sociais que predominam em cada época;

(c) a crescente produção legislativa no tocante à quantidade de hipóteses de usucapião.

(d) fortalecimento de políticas públicas que levam à instrumentalização da regularização fundiária.

Esse fenômeno deve ser prolongar no tempo por algumas décadas, até que se chegue a tal grau de desenvolvimento social que a posse voltará a perder dimensão, com a pacificação e distribuição da propriedade, como percebemos ter ocorrido nas experiências da Inglaterra, Portugal e da Espanha, por exemplo. Nesse cenário, a grande quantidade de hipóteses legais para aquisição prescritiva da propriedade provavelmente tornar-se-á despicienda. 


\subsection{DISTINÇÃO ENTRE POSSE E DETENÇÃO}

Detenção é poder de fato, que não gera consequências jurídicas (possessio naturalis). É o caso de quem detém a coisa, mas reconhece a propriedade de outro - não a possui, mas a detém - rem alteri haberi. O detentor não tem proteção jurídica. No Direito romano, estariam nessa situação o locatário, o depositário e o comodatário ${ }^{208}$ (comportando $^{2}$ exceções, como veremos a seguir, que receberam a proteção, no caso do enfiteuta e do credo pignoratício).

Em linhas gerais, detenção consiste no poder de fato sem intenção de ter a coisa como própria.

Bonfante adverte ainda que os doutrinadores modernos costumam chamar possesso (posse) também a mera detenção legal. A mera posse corporal (detenção) como, por exemplo, a do locatário ou comodatário, não tem, para o Direito romano, os efeitos da possessio ou da posse jurídica.

Algumas espécies determinadas de detenção apresentaram os efeitos e a defesa da posse, e o mesmo nome de possessio. Tais figuras excepcionais são, como mencionado, a posse do credor pignoratício, a posse do precarista, isto é daquele que obteve o gozo da coisa a título de concessão precária (precibus), relação muito frequente na antiga sociedade romana, e a posse do sequestrário. Ademais, adicionou-se, aparentemente, na época romano-helênica a posse do ager vectigalis ou enfiteuta. De todo modo, nessas figuras excepcionais, a causa específica substitui o animus possidendi, que é expressamente negado pelos jurisconsultos romanos, os quais, por exemplo, afirmam que possuidores similares possuem não pro suo, mas sim pro alieno. Posteriormente, os interditos foram estendidos ao usufrutuário, embora o usufrutuário também apresente apenas a possessio corpore ${ }^{209}$.

A detenção é um instrumento de posse exercido a favor de outro, na visão de Saleilles. A detenção é um prolongamento e manifestação pura e simples da posse de outro ${ }^{210}$.

\footnotetext{
208 Thomas Marky. Curso Elementar de Direito Romano, p. 74.

${ }^{209}$ Pietro Bonfante. Instituzioni di Diritto Romano, p. 314-316.

${ }^{210}$ Raymond Saleilles, De la possession des meuble, p. 26.
} 
Ensina Moreira Alves, em estudo específico sobre a detenção, que dos autores renascentistas até Savigny a detenção era entendida como o corpus (relação física com a coisa), que poderia ser elevada à condição superior de posse caso presente o animus específico, o animus domini ou o animus rem sib habendi. Esse conceito fica patente no exemplo claro, elaborado por Savigny, do barqueiro que com seu barco cruza as águas, possuindo seu barco, mas não a água sobre a qual ele navega ${ }^{211}$; nesse sentido, para possuir a coisa não basta detê-la, mas há necessidade de se querer detê-la (é um animus possidendi); havendo o comportamento de proprietário, excluindo os demais dessa relação, sendo então necessário o animus domini.

Ihering é um grande crítico da falta de reconhecimento pela teoria subjetiva de proteção da detenção alieno nomine, indignando-se com a falta de equidade: "será menos lesada pela expulsão de um arrendatário do que pelo enfiteuta?". E responde: "a violência é sempre violência seja qual for a pessoa contra quem se exerça. Uma ação que como tal, independentemente da pessoa lesada, encerra em si uma injustiça, não pode ser e deixar de ser injusta segundo a diversidade das hipóteses". E chega à conclusão de que a intenção de Savigny de refutar a proteção ao detentor é falha ${ }^{212}$.

Para Chamoun, a detenção era elemento material da posse, relação simples com a coisa, despida de autonomia, e privada de qualquer proteção jurídica ${ }^{213}$.

Nas palavras de Moreira Alves, "posse e detenção não se distinguem pela existência, naquela, de um animus específico, seja o animus rem sib habendi, seja o aniumus domini. Ambas, pelo contrário, se constituem dos mesmos elementos: o corpus (que é o elemento exterior) e o animus (a affectio tenendi, que é o elemento interior). Esses elementos, porém, não podem existir um sem o outro (...)." Para Ihering, se chegaria à detenção mediante um aspecto objetivo (daí a denominação teoria objetiva) consistente em dispositivo legal que retirar o caráter possessório de determinadas situações. "Detenção,

\footnotetext{
211 Jose Carlos Moreira Alves. Posse e Propriedade. Doutrina e Jurisprudência. Coordenação de Yussef Said Cahali; A detenção no direito brasileiro (conceito e casos), p. 2.

212 Rudolf von Ihering. Fundamentos dos Interditos Possessórios, p. 29.

${ }^{213}$ Ebert Chamoun. Instituições de Direito Romano, 220.
} 
pois, para Ihering, é uma posse degradada: uma posse que, em virtude de lei, se avilta em detenção" 214 .

No ensinamento de Washington e do professor Maluf, detenção equivale à posse natural, enquanto a posse no sentido legal corresponde à posse civil. Por força do artigo 1.198 do Código Civil, aquele que se limita a deter a coisa em nome de outro, ou de acordo com as instruções deste, não é considerado possuidor. Nesse sentido, as doutrinas de Savigny e Ihering se aproximam, pois, para o primeiro, é essencial à posse o animus domini (vontade de possuir como proprietário) e o animus rem sibi habendi (vontade de possuir para si), enquanto para o segundo a posse é exteriorização da propriedade, não a apresentando o simples detentor. Para ambos, este detentor apenas tem a coisa em seu poder mediante a manifestação da vontade do proprietário (o verdadeiro possuidor) ${ }^{215}$.

No ensinamento de Humberto Theodoro Junior, "a diferença prática maior entre o pensamento de Savigny e Ihering situa-se, finalmente, na conceituação de detenção, pois enquanto o primeiro a assenta na ausência do animus domini, o último a situa objetivamente no vínculo contratual ou legal que define a posição de alguém que age em nome de outrem. Assim, para a teoria de Savigny, o preposto passaria a possuidor, com direito a proteção interdital, no exato momento em que descumprisse a ordem de restituir a coisa ao proponente. Devemos lembrar que o atual artigo 1.198 do Código Civil também preconiza que aquele que detém em nome de outro é apenas detentor e não possuidor ${ }^{216}$.

O fenômeno da detenção está intimamente ligado aos fâmulos da posse (ou servidor da posse). Ocorre a detenção quando o ordenamento não protege a relação da pessoa com a coisa, pois a pessoa apenas a detém.

É o que prevê o artigo 1.198 do Código Civil, conforme o ensinamento de Venosa: "aquele que transitoriamente apanha objeto para examiná-lo ou transportá-lo tem contato material

\footnotetext{
214 Jose Carlos Moreira Alves. Posse e Propriedade. Doutrina e Jurisprudência. Coordenação de Yussef Said Cahali; A detenção no direito brasileiro (conceito e casos), p. 4.

${ }^{215}$ Washington de Barros e Carlos Alberto Dabus Maluf. Curso de Direito Civil, Direito das coisas, p. 43.

${ }^{216}$ Humberto Theodoro Junior. Posse e Propriedade, p. 4.
} 
com a coisa, pode ter aparência de posse, mas não tem a posse. Não existe vontade nessa posse" 217 .

Finaliza Venosa que "por conseguinte, pode ser concluído existir na detenção o corpus, mas não o animus".

Assim, fâmulo da posse é aquele que, em virtude de sua situação de dependência econômica ou de um vínculo de subordinação à outra pessoa (possuidor direto ou indireto), exerce sobre o bem não uma posse própria, mas a posse desta última e em nome desta, em obediência a uma ordem ou instrução; por esta razão este será apenas o detentor, nos termos do artigo 1.198, parágrafo único, do Código Civil ${ }^{218}$.

Diferentemente da posse, a detenção “(...) é mero contato material com a coisa e, como tal, fenômeno despido de proteção no plano dos direitos reais. Representa relação apenas de fato, pois nem deriva de direito, nem gera direito (nuda detencio, ou posse natural)". Por outro lado, a posse se funda em direito, no caso do jus possidendi, ou dá origem a um direito, na hipótese do jus possessionis ${ }^{219}$.

Por fim, para Ascensão, "há detenção sempre que, nos termos da teoria objetiva, ao corpus acresce uma situação que impede que se fale em posse"220, como os atos por mera tolerância, em que o sujeito atua em nome de outrem. E conclui Ascensão: "portanto, havendo o corpus, há em princípio a posse, exceto se a causa da situação a desvalorizar para mera detenção".

Assevera Moreira Alves que, no Brasil, a posse precária corresponde à posse direita (que é verdadeira posse), bem como que o Código Civil de 1916 seguiu a teoria de Ihering para distinguir posse de detenção ${ }^{221}$. Sobre essa última afirmação, pode-se dizer o mesmo do Código Civil de 2002.

\footnotetext{
${ }^{217}$ Silvio de Salvo Venosa. Código Civil Comentado Vol. XII, p. 41.

${ }^{218}$ Maria Helena Diniz. Curso de Direito Civil Brasileiro, v. 4, direito das coisas, p. 40.

${ }^{219}$ Carlos Alberto Bittar. Direitos Reais, p. 31.

${ }^{220}$ José de Oliveira Ascensão. Direito das Coisas - reais, p. 89.

221 Jose Carlos Moreira Alves. Posse e Propriedade. Doutrina e Jurisprudência. Coordenação de Yussef Said Cahali; A detenção no direito brasileiro (conceito e casos), p. 18.
} 


\subsection{PROTEÇÃO DA POSSE}

Ensina Biondo Biondi que os interditos possessórios uti possidetis e utrubi tinham a função da manutenção da posse, tendo o primeiro aplicação para os imóveis e sendo outorgado ao possuidor atual, enquanto o segundo era válido para os móveis e se outorgava àquele que tinha posse por maior período de tempo, no último ano. $\mathrm{O}$ interdito quod vi aut clam também era utilizado aos imóveis ${ }^{222}$.

Para o ilustre romanista, as ações possessórias não poderiam ser consideradas ações reais no Direito romano. Apesar de a posse ser considerada um direito dentro dos limites em que é tutelada por lei, uma vez que a defesa somente poderia ser impetrada contra o autor da turbação ou da perturbação, “ainda que referentes a imóveis, não são imobiliárias, faltando o pressuposto de serem relativas a direitos reais" ${ }^{223}$. Ações reais são, portanto, aquelas que podem ser impetradas contra qualquer indivíduo, indeterminado, pois são genéricas; as ações possessórias não apresentam essa característica: “o possuidor será defendido apenas contra ser despojado ou perturbado na posse, sendo que as respectivas ações apenas podem ser ensejadas contra o autor de tais despojamento e perturbação; a defesa nasce, portanto, somente de uma ação realizada por uma pessoa determinada, contra a qual se pode executar a ação correspondente", completa o autor.

A posse é a sentinela na defesa da propriedade. Para Caio Mario, a explicação mais vantajosa, do ponto de vista prático, é a de Iherig, pois justifica a concessão de interditos “àquele que defende a sua condição de possuidor, contra quem quer que o ameace, perturbe ou esbulhe, reservando-se para o petitório a discussão profunda do direito, quando estiver travada a batalha da propriedade" ${ }^{224}$.

A proteção possessória aparece, assim, como um complemento indispensável à propriedade, de forma que o direito à propriedade sem a ação possessória seria a coisa

${ }^{222}$ Biondo Biondi. Los Bienes, p. 103.

${ }^{223}$ Ibid., p. 128.

${ }^{224}$ Caio Mario da Silva Pereira. Instituições de Direito Civil - direitos reais, Vol. IV, p. 32. 
mais imperfeita do mundo: "para ser protegido como possuidor, basta que estabeleça sua posse, e esta proteção se estenderá tanto ao não proprietário como ao proprietário ${ }^{\mathbf{2 2 5}}$.

No que se refere à defesa da posse, salienta Saleilles a importância de manter, mesmo que a título provisório, a ordem aparente das relações sociais quanto ao uso dos bens do mundo. A relação aparente que une o indivíduo à coisa, e que lhe permite utilizar a coisa conforme sua destinação, deve ser protegida e defendida por si só, como um elemento de ordem social. As coisas devem permanecer no seu estado - a ordem aparente da sociedade deve ser mantida ${ }^{226}$.

No dizer de José de Oliveira Ascensão, "se alguém, pela violência, se apodera de coisa que outro tem em seu poder, a quebra da paz tem uma sanção natural - restituem-se manu militari os sujeitos à situação anterior. A tutela da situação de fato é um mero reflexo desta defesa da paz social" 227.

Uma das grandes lições defendidas por Ihering é a proximidade com que entende a posse da propriedade, e, nesse sentido, a proteção da posse é um postulado da proteção da propriedade, é o complemento necessário do sistema de propriedade entre os romanos ${ }^{228}$.

Ihering indica que o Direito romano, citando também a conditio furtiva e a actio legis Aquilae (nas quais o autor não precisava demonstrar a sua propriedade), não visava proteger a posse em si, mas sim aquilo que estaria por trás dela: a propriedade. "O direito romano concede ao proprietário a conditio furtiva e a actio legis Aquilae, mas lhe facilita a prova delas, contentando-se com a demonstração do simples estado de fato (exterioridade da propriedade), isto é, da posse: o possuidor é tido por proprietário até prova em contrário" 229.

Por isso, entende Ihering que a posse é uma posição ou reduto da propriedade; não é a posse a razão da defesa dos interditos, mas o escopo último da defesa é a própria

\footnotetext{
${ }^{225}$ Rudolf von Jhering. Ouevres Choisies, Possession. Théorie simplifiée et mise à la portée de tout le monde, $\mathrm{p} 231$.

${ }^{226}$ Raymond Saleilles, De la possession des meuble, p. 66.

${ }^{227}$ José de Oliveira Ascensão. Direito das Coisas - reais, p. 64

${ }^{228}$ Rudolf von Ihering. Fundamentos dos Interditos Possessórios, p. 60.

${ }^{229}$ Ibid., p. 64-65.
} 
propriedade. Nesse sentido, afirma que na posse o proprietário se defende contra os primeiros ataques ao seu direito, indicando que nessa primeira batalha ou escaramuça, basta uma arma menos potente para a defesa, usando a comparação com uma arma branca, deixando a artilharia pesada para depois ${ }^{230}$. A razão da defesa da posse não se encontra ou permanece nela mesma, mas sim na propriedade.

Mas seria impossível proteger o proprietário, nessas condições, sem também proteger o não proprietário - que acaba se aproveitando dessa defesa, pois ela prescinde da demonstração do título, apenas do fato. Afirma Ihering que "efetivamente, se aprova realmente necessária da propriedade limita-se a demonstração da sua exterioridade, esta facilidade reverte em vantagem de todo indivíduo que está nas circunstâncias de se prevalecer de tal entendimento. Dessa sorte, adquire a posse em relação à propriedade uma independência tal que, em lugar de servir exclusivamente à propriedade, pode também lhe ser contrária ${ }^{231}$, .

Também na common law, no tocante à defesa da posse, uma pessoa que está de facto ou detém a posse aparente (apparent possession) pode recorrer aos remédios de um possuidor contra estranhos ou invasores (wrongdoers) ${ }^{232}$.

A common law não protege a ocupação em sentido estrito, mas apenas indiretamente, pois protege as situações em que existe posse sobre um imóvel, com três diferentes ações: (a) ação para retomada do bem (action for recovery of land); (b) ação de invasão (trespass); e (c) ação de esbulho (nuisance) ${ }^{233}$.

A finalidade da posse, para Ihering, é a facilidade da prova em benefício do proprietário a inteligência desse aspecto é o ponto central de toda a teoria da posse. Confronta-se Ihering, portanto com outros pontos de vista que indicam ser o valor da posse na própria posse ("o fim da posse na própria posse"); ou seja, por procurar facilitar a defesa do proprietário, a lei paga também um preço, causando a defesa de toda posse (não só a do proprietário), apesar de indicar que na prática essa distinção acaba não tendo importância,

\footnotetext{
230 "Contra o ladrão não se emprega o canhão", afirma Ihering (p. 65).

${ }^{231}$ Rudolf von Ihering. Fundamentos dos Interditos Possessórios, p. 65.

${ }^{232}$ Frederick Pollock e Robert Samuel Wright. An essay on possession in the common law, p. 147.

${ }^{233}$ Mark Wonnacott . Possession of land, p. 162.
} 
pois a proteção legal é a mesma. Assim, sobre a possibilidade de um ladrão ter a posse defendida, acredita que "mais vale um velhaco excepcionalmente partilhe de um benefício da lei, que ver este benefício recusado a quem o merece - isto somente para excluir o primeiro". Por todas essas características, a posse "é uma propriedade que começa, a maior parte dos bens acha-se em poder dos verdadeiros proprietários" 234.

O possuidor poderia impetrar os interditos possessórios. Em geral a proteção interdital era aplicada a quem podia ser proprietário e às coisas suscetíveis de propriedade. Por isso, as pessoas alieni iuris e as res extra commercium estavam excluídas da posse. Quem podia ingressar com os interditos detinha a posse ad interdicta: o proprietário civil ou pretoriano, peregrino ou provincial, o possuidor de boa-fé ou de má-fé, o precarista, o credor pignoratício, o sequestrário, o locatário do ager vectigalis e o enfiteuta. Por outro lado, no Direito romano eram considerados simples detentores, sem direito à proteção dos interditos, o locatário de um imóvel (colonus) ou de uma casa a curto prazo (inquilinus), o comodatário, o depositário comum e o usufrutuário ${ }^{235}$.

Assim, percebe-se que, em última instância, as regras de aplicação ou não da proteção interdital baseavam-se mais em imposições da vida prática do que em construções teóricas - lembrando Chamoun que só isso poderia explicar a ausência de proteção aos colonus, inquilinus, comodatário, depositário e usufrutuário. Isso porque, em regra, na verdade, a proteção da posse se destinaria a proteger o que geralmente está por trás dela, a propriedade, "da qual seria a posse uma guarda avançada. A prova da propriedade é longa e difícil, pois, a rigor, exige a demonstração da limpidez de sua história, pelo menos durante o prazo do usucapião. Para facilitá-la é que se teria criado a proteção possessória" 236

\footnotetext{
${ }^{234}$ Rudolf von Ihering. Fundamentos dos Interditos Possessórios, p. 66-71.

235 Claro está que o Direito moderno repeliu essa distinção presente no Direito romano, considerando também possuidores o locatário, o comodatário e o usufrutuário. Acredita-se que, inicialmente, essa distinção se deu derivada da crença de que o possuidor não poderia prescindir do animus domini, portanto tais pessoas, por não exercerem a posse com tal animus, também não poderiam ser consideradas possuidores. Mas isto não bastaria para explicar, completando tal raciocínio "circunstâncias de ordem social e prática (...) para que sua situação econômica inferior se mantivesse. Os interesses práticos da vida é que aconselhariam a outorga ou não da proteção interdital". (Ebert Chamoun, p. 226).

${ }^{236}$ Ebert Chamoun. Instituições de Direito Romano, p. 227.
} 
No decorrer da história do Direito romano, percebe-se também uma grande evolução no entendimento do fenômeno possessório, com crescente distanciamento e autonomia da propriedade e seus efeitos. De proteção avançada da propriedade, passou a ser considerada direito em si, abrigado no direito à propriedade.

Ensina Edmundo Pereira Lins, de forma resumida, que, havendo posse, o proprietário pode reclamar o seu retorno quando dela desprovida, pelo jus possidendi; caso esse proprietário tenha transferido legitimamente sua posse a um terceiro, este também pode recobrá-la por força do jus possessionis ${ }^{237}$.

No ensinamento de Washington e Maluf, o jus possidendi corresponde ao direto à posse, decorre do direito de propriedade, um atributo do domínio. Por sua vez, o jus possessionis corresponde ao direito de posse, resultante da própria posse exclusivamente, compreendendo (a) o poder sobre a coisa; e (b) sua defesa pelos interditos. Abrange, portanto, "o complexo dos direitos que a posse, por si só, gera para o possuidor". A finalidade das ações possessórias é o jus possessionis ${ }^{238}$.

Para Carlos Roberto Gonçalves, o jus possessionis - que para o autor também é posse formal - ocorre quando alguém mantém-se mansa e pacificamente em um imóvel por um prazo superior a ano e dia - criando uma situação possessória que proporciona um direito à proteção dessa posse. É derivada de uma posse autônoma, independente de qualquer título. Já o jus possidendi, que para o autor também é posse causal, ocorre quando o direito à posse é derivado por título transcrito, não havendo posse autônoma, mas sim representando o conteúdo de um direito real. Mas lembra Gonçalves que “ tanto no caso do jus possidendi (posse causal, titulada) como no do jus possessionis (posse autônoma ou formal, sem título) é assegurado o direito à proteção dessa situação contra atos de violência, para garantia da paz social" 239 . Assim, "o jus possessionis persevera até que o jus possidendi o extinga".

\footnotetext{
${ }^{237}$ Edmundo Pereira Lins. Estudos Jurídicos na Cátedra e na Judicatura. Ensaio sobre a Posse (direito romano e civil), p. 119.

${ }^{238}$ Washington de Barros e Carlos Alberto Dabus Maluf. Curso de Direito Civil, Direito das coisas, p. 45.

${ }^{239}$ Carlos Roberto Gonçalves. Direito Civil Brasileiro, Direito das coisas, p. 46.
} 


\subsubsection{IUS POSSESSIONIS (AÇÕES POSSESSÓRIAS)}

O remédio possessório tem que ser rápido; caso contrário, se dependesse de provar o título, demoraria muito, e o direito restaria prejudicado ${ }^{240}$. "Assim, a situação de fato é protegida, não somente porque aparenta um direito, mas também a fim de evitar violência e conflito. O legislador prefere, num primeiro enfoque, proteger o possuidor, ainda que este não tenha relação juridicamente perfeita e técnica com a coisa. (...) Defende-se a posse porque é uma situação de fato que provavelmente envolve um direito" ${ }^{241}$.

Ações possessórias são análogas, a invocação de uma por outra não prejudica ou induz à nulidade, desde que satisfeitos os requisitos de uma delas (há conversibilidade entre os interditos possessórios). Buscam "resolver rapidamente a questão originada do rompimento antijurídico da relação estabelecida pelo poder sobre a coisa, sem necessidade de debater a fundo a relação dominial" ${ }^{242}$. Para Caio Mario são também ações reais.

Indica Venosa que "o processo possessório visa manter o estado de fato até que, se for necessário e conveniente, se declare o estado de direito" ${ }^{243}$. No rito sumário ocorrem as ações possessórias, conforme disposto no artigo 275, II, do Código de Processo Civil.

Excepcionalmente e sob certas circunstâncias, a lei permite a autotutela que, nos termos do artigo $1.210, \S 1^{\circ}$, do Código Civil trata-se da legítima defesa da posse. Ensina Venosa ${ }^{244}$ que são duas as hipóteses de autotutela prevista em lei:

(a) legítima defesa, quando a posse é ameaçada;

(b) desforço imediato, quando a posse é perdida: "para que o possuidor valha-se da defesa de mão própria, faz-se necessário a turbação ou o esbulho e uma reação imediata: contanto que o faça logo". Venosa apresenta dois exemplos bastante ilustrativos, um de coisa móvel

\footnotetext{
${ }^{240}$ Nesse sentido, indica Venosa que "prefere o ordenamento proteger sempre e com maior celeridade e eficácia o que detém aspecto externo da propriedade, a investigar em cada caso, e demoradamente, o título de propriedade e senhor". (p. 31).

${ }^{241}$ Silvio de Salvo Venosa. Direitos Reais, p. 29.

242 Caio Mario da Silva Pereira. Instituições de Direito Civil - direitos reais, Vol. IV, p. 52.

${ }^{243}$ Silvio de Salvo Venosa. Direitos Reais, p. 118.

${ }^{244}$ Ibid., p. 120.
} 
e outro de bem imóvel. No primeiro caso, havendo furto ou roubo de bem móvel, pode a vítima correr atrás e reaver seu bem. No segundo caso, havendo a invasão de um prédio cabe ao ofendido reingressar tão logo ocorrido o fato, com a força necessária, pois "passadas a oportunidade e conveniência da autodefesa, cabe ao sujeito recorrer às vias judiciais, sob pena de praticar ilícito penal", sendo crime tipificado no Código Penal o exercício arbitrário das próprias razões. Há que haver imediata repulsa constatada no caso prático. $\mathrm{O}$ direito de defesa compete tanto ao possuidor direto como ao indireto.

Para Marcus Vinicius Rios Gonçalves, tanto o possuidor direto como o indireto, bem como o detentor (servidor da posse) podem fazer uso da autodefesa prevista no $\S 1^{\circ}$ do artigo 1.210 do Código Civil de 2002. A autotutela pode ser empregada em casos de esbulho ou turbação. Pela lei, em um primeiro momento é dado ao possuidor agir para manter sua posse, cabendo a legítima defesa (com utilização moderada dos meios necessários à manutenção da posse) enquanto houver agressão atual ou iminente, lembrando o autor que "não há legítima defesa contra atos pretéritos"245.

No ensinamento de Washington e do professor Maluf, os antigos interditos do Direito romano (correspondentes à decisão proferida pelo magistrado no juízo possessório, interim dicuntur) evoluíram até os dias de hoje, resultando nas três principais ações possessórias: manutenção, reintegração e interdito possessório. As três modalidades do Direito romano são: (a) adipiscendae possessionis, que não visava proteger posse preexistente, mas sim determinar em juízo aquele a quem ela seria atribuído; (b) retinendae possessionis, defesa da posse contra atos turbativos, sendo usado o interdito uti possidetis para a defesa de bens imóveis; (c) recuperandae possessionis, que buscava restituir a posse àquele que a perdeu de forma violenta, com ou sem o emprego de armas (de vi armada ou de vi cotidiana, respectivamente) $)^{246}$.

O Direito canônico, para a defesa de bens dos bispos, introduziu a actio spolii, que mais tarde foi estendida a todo possuidor esbulhado, mediante reintegração.

\footnotetext{
${ }^{245}$ Marcus Vinicius Rios Gonçalves. Dos Vícios da Posse, p. 85-88.

${ }^{246}$ Washington de Barros e Carlos Alberto Dabus Maluf. Curso de Direito Civil, Direito das coisas, p. 55.
} 
Assim, são reconhecidos como interditos possessórios três ações possessórias: manutenção de posse, reintegração de posse e interdito proibitório.

(a) interditos retinendae possessionis (manutenção de posse) - apresenta finalidade defensiva típica. Há embaraço, mas não a perda da posse, justificando ao juiz a emissão de mandado de manutenção; busca-se proteger a posse, afastando-se a diabolica probatio. "A sentença mantenedora da posse deverá restituir ao status quo ante, com a cessação da moléstia" 247

A ação de manutenção é usada em casos de turbação da posse, "os atos turbativos molestam e dificultam a posse, em suprimi-la do sujeito". Ensina Venosa que a "turbação é ofensa média à posse", pois o exercício da posse é prejudicado, embora não suprimido ${ }^{248}$.

Para Ebert Chamoun a proteção da posse "não era assegurada por ações, mas por ordens que o magistrados expediam (...), os interdicta”. Eram dois interditas ${ }^{249}$ : (a) interdicta retinendae possessionis - destinava-se a assegurar a conservação/manutenção da posse, preservando o possuidor contra turbações; resguardar a posse não viciosa e atual; subdividindo-se em: (a.i) interdictum uti possidetis - dizia respeito a imóveis e protegia quem tivesse a posse atual, isto é "quem a tivesse no momento em que intentou o interdito e não a houvesse adquirido violenta, clandestinamente ou a título precário do seu adversário no processo; era um interdictum duplex, pois ambos os litigantes funcionavam como autor e réu ao mesmo tempo e o pretor decidia em favor de quem preenchesse as condições do interdito"; e (a.ii) interdictum utrubi - relativo a coisas móveis, também era uma interdictum duplex.

(b) interditos recuperandae possessionis (reintegração de posse) - destinado a reaver a posse perdida; se posse nova (esbulho ocorrido a menos de ano e dia), a ação inicia-se pelo mandado liminar para que o possuidor seja prontamente reintegrado; a ação recebe o nome também de força nova espoliativa. Caso o esbulho tenha ocorrido a mais de ano e dia, o

\footnotetext{
${ }^{247}$ Caio Mario da Silva Pereira. Instituições de Direito Civil - direitos reais, Vol. IV, p. 56.

${ }^{248}$ Silvio de Salvo Venosa. Direitos Reais, p. 146.

${ }^{249}$ Ebert Chamoun. Instituições de Direito Romano, p. 224.
} 
juiz ouvirá a parte adversa, de forma a determinar a melhor posse, verificando também se houve esbulho mediante clandestinidade, violência ou precariedade.

Para Ebert Chamoun, os interdicta recuperandae possessionis visavam a recuperação da posse, buscando a reintegração na posse que foi anteriormente esbulhada; e se subdividiam em:

(i) unde vi, subdivididos em interdictum de vi cottidiana (concedido ao possuidor de um imóvel esbulhado mediante violência ordinária; devia o possuidor deter a posse justa e buscar o interdito antes de um ano a partir do esbulho) e interdictum de vi armata (protegia o possuidor expulso à mão armada, a despeito de posse viciosa ou de haver transcorrido mais de um ano após o esbulho).

Como oposição aos interditos, cabia exceptio vitiosae possessionis, alegando a posse injusta. "No direito justinianeo os dois interditos de vi cottidiana e de vi armata aparecem amalgamados num único interdito unde vi concedido durante o prazo de um ano, sem embargo dos vícios da posse do reclamante (spoliatus ante omnia restituendus) ${ }^{\natural 250}$.

(ii) interdictum de precario - resguardava direitos a título precário, para restituição da coisa concedida. Acabou superado quando o precarium tornou-se um contrato com ações próprias.

Hodiernamente, usada em casos de esbulho da posse, ocorre a perda da posse, o possuidor é despojado do poder de fato sobre a coisa. Há efetiva privação injustificada da posse. Pede-se a restituição da coisa, ou seu valor, se ela não mais existir.

(c) interdito proibitório - consiste na defesa preventiva da posse, ante uma ameaça de esbulho ou turbação; segundo Caio Mario "consiste em armar o possuidor de mandado

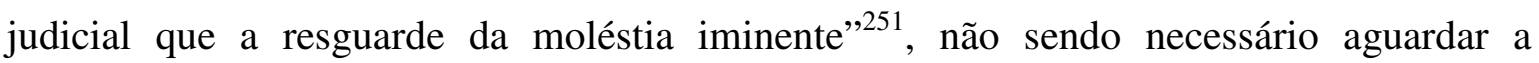
turbação ou o esbulho, sob pena de o réu pagar multa pecuniária.

\footnotetext{
${ }^{250}$ Ebert Chamoun. Instituições de Direito Romano, p. 226.

${ }^{251}$ Caio Mario da Silva Pereira. Instituições de Direito Civil - direitos reais, Vol. IV, p. 59.
} 
Assim, será usado quando houver necessidade de remediar uma ameaça de violência iminente. Tem caráter preventivo: não pode ainda ter ocorrido o efetivo esbulho ou a turbação. A ameaça à posse já é uma forma de violação de direito. "É usada na situação de agressão iminente ou receio justificável de perturbação da posse. Cuida-se de situação em que a turbação ou esbulho são altamente prováveis e atuais. (...) Importa o temor de que algo suceda contra a posse" ${ }^{, 52}$. Ao expedir mandado proibitório, estabelece o juiz a multa pecuniária se o réu transgredir a ordem.

Ainda sobre o interdito proibitório, temos o exemplo jurisprudencial dos dois arrendatários que ajuízam contra terceiros agricultores o interdito. Porém, uma vez findo o prazo do arrendamento, entregam o imóvel rural ao proprietário, e pretendem desistir da ação, pela perda do objeto. No entanto, esta pretensão não é atendida pelo juiz, pois o processo deveria ter prosseguimento para a apreciação da pretensão indenizatória por parte dos réus. A razão: "as ações possessórias têm caráter dúplice, isto é, o réu, na contestação, pode contra-atacar, demandando a proteção possessória e indenização pelos prejuízos resultantes de turbação ou esbulho cometido pelo autor", restando ser julgado este pedido feito pelos réus $^{253}$.

A escolha entre as três ações possessórias depende do grau de ofensa à posse.

Por fim, Washington e o professor Maluf indicam a existência de seis modalidades de ações para a defesa da posse no Brasil, observando rito mais célere, pois dispensam a citação do executado $^{254}$ :

(a) ação de manutenção de posse (ação de força nova turbativa) - retinendae possessio. $\mathrm{O}$ possuidor é mantido na posse em que foi turbado, mediante turbação de fato ou de direito; não obstante o ato turbativo, "o possuidor continua na posse dos bens, apenas cercado em

\footnotetext{
${ }^{252}$ Silvio de Salvo Venosa. Direitos Reais, p. 141.

${ }^{253}$ Paulo Guilherme de Almeida. Temas de Direito Agrário, p. 139.

${ }^{254}$ Washington de Barros e Carlos Alberto Dabus Maluf. Curso de Direito Civil, Direito das coisas, p. 5666.
} 
seu exercício". Apresenta o prazo de ano e dia ${ }^{255}$. Exemplo: alguém entra em imóvel de terceiro, saindo e entrando, ofendendo a posse.

(b) ação de reintegração de posse (ação de força nova espoliativa), interdito recuperatório, ação de esbulho - recuperandae possessionis. Ocorre o esbulho (e não apenas turbação), culminado com o arrebatamento da posse, pois o possuidor vem a ser privado da posse. Serve à recuperação da posse esbulhada ou perdida; com a privação da posse, de forma violenta, clandestina ou mediante abuso de confiança. Também deve datar de menos de ano e dia.

(c) interdito proibitório - destina-se a proteger a posse apenas ameaçada é proteção preventiva, quando há iminência ou ameaça de ser molestada, não havendo efetivação pela turbação ou esbulho.

(d) ação de imissão de posse; na verdade imissão na posse. O atual Código de Processo Civil não mais a previu; todavia, para Washington e o professor Maluf poderia ainda ser impetrada, desde que sujeita ao rito ordinário.

(e) embargos de terceiro senhor e possuidor. Embargos usados em arrematação ou adjudicação judicial (risco de molestação por ato de apreensão judicial), mas o terceiro embargante tem que ser possuidor ou proprietário, sob pena de rejeição liminar dos embargos pelo juiz.

(f) ação de nunciação de obra nova. Caso exista obra nova em imóvel vizinho, em vias de conclusão, que possa prejudicar o domínio ou a posse sobre o outro imóvel. "Seu objetivo é impedir que o prejuízo se consuma pela ultimação da obra”. Deve ser requerida antes da conclusão da obra.

\footnotetext{
${ }^{255} \mathrm{O}$ prazo de ano e dia é considerado extintivo, estabelecendo a distinção entre ação de força nova (cabe a expedição de mandado limiar de manutenção ou reintegração) e ação de força velha. Ambas seguirão o rito ordinário, conforme o artigo 931 do Código de Processo Civil. Assim, o prazo de ano e dia encontra-se no artigo 924 do Código de Processo Civil. Normalmente, os Códigos Civis não abordam os procedimentos de defesa da posse, por consistirem em matéria processual.
} 
Existem ainda outras ações: (a) ação de dano infecto (não propriamente possessória, pois haverá de receio de ruína de prédio vizinho ou vício na construção); (b) nunciação de obra nova (também seria uma ação mista de possessória com cominatória, buscando embargo da obra e multa); (c) imissão de posse (para Ihering, contrariando Savigny, seria uma ação possessória, interdito adipiscendae piossessionis); e (d) embargos de terceiro.

A exceção de domínio consiste na defesa do réu fundada no domínio (exceptio dominii), argumento que não pode ser acolhido, pois nihil communi habet proprietas cum possessione. Ensina Caio Mario ${ }^{256}$ que a ninguém assiste, sob alegação de propriedade, perturbar a posse alheia. A saída para este proprietário seria a promoção da reivindicação, buscando reaver a coisa pela via petitória.

Outros efeitos da posse estão compreendidos na percepção de frutos, bem como na indenização por benfeitorias e direito de retenção; aspectos que merecem estudo aprofundado em outra sede, assim como os aspectos de perda da posse (abandono, tradição, destruição, posse de outrem, constituto possessório).

\subsubsection{IUS POSSIDENDI (AÇÕES PETITÓRIAS)}

O jus possidendi versa sobre o direito de posse fundado na propriedade, enquanto o jus possessionis versa sobre o direito fundado no fato da posse ${ }^{257}$. No jus possidendi há coincidência - o direito de posse é fundado na propriedade. Todavia, não está abarcado pela teoria da posse: "a teoria pura da posse, isto é, a faculdade jurídica de direitos, refletese, portanto, no ius possessionis", contrapõe-se ao jus possessionis.

Os juízos possessórios e petitórios não se misturam - separata essa debet possessio a proprietate. "Se de natureza possessória o pleito judicial, cumpre apenas indagar quem é o possuidor, para a este outorgar-se a proteção possessória”. Ou seja, dito de outra forma, é aceita como inadmissível a querella proprietatis nas ações possessórias ${ }^{258}$.

${ }^{256}$ Caio Mario da Silva Pereira. Instituições de Direito Civil - direitos reais, Vol. IV, p. 58.

${ }^{257}$ R. Limongi França. A Posse no Código Civil (noções fundamentais), p. 17.

${ }^{258}$ Washington de Barros e Carlos Alberto Dabus Maluf. Curso de Direito Civil, Direito das coisas, p. 70. 
Deve-se acrescentar que, de acordo com Gustavo Tepedino, o exercício da tutela da proteção possessória, à luz da Constituição Federal de 1988, não mais se restringe à proteção da situação de fato pré-existente, mas dependerá de novos fatores, “dependendo da compatibilidade da utilização atribuída à coisa, no caso concreto, com situações jurídicas constitucionalmente merecedoras de tutela. Em outras palavras, apartada a propriedade, a tutela possessória depende do direcionamento do exercício possessório a valores protegidos pelo ordenamento, que a legitimem e justifiquem sua proteção legal, inclusive contra o verus dominus". Assim, volta a apregoar o autor sobre a tutela da posse: “o interesse nela contido só se legitima e se torna digno de proteção jurídica na medida em que vincula aos valores merecedores da tutela constitucional" 259.

${ }^{259}$ Gustavo Tepedino. Comentários ao Código Civil, Direito das Coisas, V. 14, Coordenador Antônio Junqueira de Azevedo, p. 57-58. 


\subsection{POSSE DE DIREITOS}

Todas as coisas que podem ser objeto de propriedade, corpóreas ou incorpóreas, podem ser objeto de posse. Todavia, no tocante à posse de direitos, uma grande divergência na doutrina foi verificada, quanto a esta possibilidade.

Ruy Barbosa, em obra bastante conhecida, indica que, não obstante ter tido alguma guarida no Direito canônico no sentido de possibilitar a posse de direitos, o entendimento que prevaleceu no Brasil, inclusive nos tribunais, é no sentido de que "a coisa é que é objeto da posse e que é o poder de fato que se protege por meio das ações possessórias" 260.

No entanto, o autor expressa sua certeza quanto à extensão da proteção possessória aos direitos, baseada exatamente na aplicação do Direito canônico: "ninguém ainda justificou melhor a ampliação moderna, devida ao direito canônico, da forma da posse aos direitos pessoais. Com a autoridade da sua profunda intuição do espírito da jurisprudência romana, a que Ihering mesmo rende caloroso preito, Savigny, com efeito, vem atestar que a noção canônica da posse, extensiva a direitos pessoais e, até, a funções públicas, não desnaturava a concepção romana, antes era o seu lógico desenvolvimento" 261.

Astolpho Rezende esclarece que a construção teórica de Ruy Barbosa sobre a aplicabilidade da posse aos direitos pessoais, fundada no Direito canônico, que muito influenciou as Ordenações que funcionaram por séculos no Brasil como fonte do Direito Civil, "não encontrou, porém, acolhida nos tribunais. Estes continuaram presos ao critério romanístico, só admitindo a posse das coisas corpóreas, e quase-posse dos direitos reais. Mesmo porque esta concessão não se encontrava propriamente no direito canônico, mas na opinião de alguns de seus interpretes" 262.

\footnotetext{
${ }^{260}$ Ruy Barbosa. Posse de direitos, p. 20.

${ }^{261}$ Ibid., p. 35.

${ }^{262}$ Astolpho Rezende. A posse e sua proteção, p. 41.
} 
Para Ruy Barbosa, ocorreria um situação de quase-posse que abrange o direito constituído que, por sua vez, merece proteção da defesa pelos interditos, a exemplo do que ocorre com as coisas corpóreas e correspondentes direitos reais ${ }^{263}$.

Para Vicente Ráo, a posse deve observar o entendimento de Ihering, como o poder de fato (em contraposição ao poder de direito que é a propriedade), podendo ambas estar concentradas na figura do proprietário, que exerce o ius possidendi e, nesse caso, a utilização real ou imediata da posse; ou pode ele transferir a posse a outro (posse justa), surgindo a posse mediata ou jurídica, ficando sujeito a respeitá-la; ou ainda lhe ser subtraído contra a vontade (posse injusta), e nesse caso tem acesso às ações possessórias para restabelecer a situação anterior. Disso, conclui o autor, "tirar a posse é paralisar a propriedade". Ademais, acredita ser a posse um direito, mas um direito sui generis - pois a persistência do fato da posse é condição essencial para sua existência e proteção ${ }^{264}$.

Grande parte da doutrina entende que a posse, como situação de fato, só pode ter por objeto uma coisa (e nunca posse sobre os direitos que se referem às coisas). Segundo Ascensão, "não pode haver um exercício de poderes de fato sobre um direito!". Assim, a posse recai sobre uma coisa, nos termos de um direito ${ }^{265}$. Toda posse representa a exteriorização de um direito relativo a coisas.

Assevera ainda Vincente Ráo "que a posse não é o poder físico sobre a coisa, e sim o exercício, a exteriorização de um direito, eis a noção que mais clara aparece, até evidencia, ao estudar-e a posse dos direitos" ${ }^{266}$. Nesse sentido, segue o entendimento de Ihering para "compreender na universalidade do conceito exercício ou exterioridade de um direito, quer a posse das coisas, que eles poderiam ter definido como sendo a exterioridade da propriedade, em sentido estrito, quer na posse de direitos, que, na legislação romana, consiste na exterioridade dos direitos sobre coisa alheia" ${ }^{267}$.

\footnotetext{
${ }^{263}$ Ruy Barbosa. Posse de direitos, p. 60.

${ }^{264}$ Vicente Ráo. Posse de Direitos Pessoais, p. 5-7.

265 José de Oliveira Ascensão. Direito das Coisas - reais, p. 59

${ }^{266}$ Vicente Ráo. Posse de Direitos Pessoais, p. 11.

${ }^{267}$ Como, por exemplos, a servidão, a superfície e talvez ainda a enfiteuse, havendo divergência entre os romanistas com relação a esta última, sendo inclusive aplicados os interditos quase-possessórios. (p. 11).
} 
Deve-se então indagar se o Código Civil de 1916 ampliou ou não a posse aos direitos pessoais. Lembra Vicente Ráo que o próprio Clóvis Beviláqua afastou peremptoriamente essa possibilidade, afirmando que os direitos pessoais são estranhos ao conceito da posse. No ensinamento de Farias e Rosenvald ${ }^{268}$, o mesmo raciocínio se aplica ao universo das patentes, software e demais criações da inteligência humana: "há propriedade sobre bens incorpóreos, mas a tutela possessória se restringe às coisas, ou seja, apenas a uma espécie do gênero bens, caracterizada pela materialidade. Justamente pelo fato de o Código Civil excluir da incidência das ações possessórias todo exercício de direitos que não implique poder de fato sobre a coisa, a proteção a estes bens é encontrada nas Leis $n^{0}$ 9.279/96 (patentes), $\mathrm{n}^{\mathrm{o}}$ 9.610/98 (direitos autorais) e $\mathrm{n}^{\circ}$ 9.609/90 (software), que conferem outros meios processuais de amparo ao titular de abstrações e bens intangíveis".

Por fim, acaba Vicente Ráo rendendo-se à posição intermediária, em vista da letra da lei, no sentido de que nem todo direito pessoal estaria abrangido pelo conceito de posse, mas apenas os direitos patrimoniais, ou seja, (a) o domínio; (b) os direitos reais que dele se desmembram e subsistem (jura in re aliena); (c) os demais direitos patrimoniais da pessoa que podem ser reduzidos a valor pecuniário. E acrescenta crítica ao Código, por não ter amparado os direitos não patrimoniais e os direitos políticos ${ }^{269}$ no conceito de posse.

\footnotetext{
${ }^{268}$ Cristiano Chaves de Farias; Nelson Rosenvald. Direitos reais, p. 57.

${ }^{269}$ Vicente Ráo. Posse de Direitos Pessoais, p. 137.
} 


\section{CLASSIFICAÇÃO DA POSSE}

Apresentaremos a seguir as principais classificações construídas pela doutrina para a posse.

Antes, porém, cabe ressaltar que o Ministro Teori Albino Zavascki traça curiosa distinção entre a posse simples, enunciada genericamente no artigo 1.196 do Código Civil, e posse qualificada, que "por um elemento fático caracterizador da função social: é a posse exercida a título de moradia e enriquecida pelo trabalho ou por investimentos" 270 , e teria um atributo a mais (comparativamente com uma posse "simples"), a realização de obras e benfeitorias no bem possuído, concretizando a realização da função social.

O dispositivo constitucional, conforme veremos adiante, impõe a verificação de condições (consistente no trabalho e na moradia) para o benefício da usucapião, caso contrário não estarão presentes os requisitos legais necessários à aquisição da propriedade pelo possuidor. Questiona-se se a imposição de exigências como estas ajudam a facilitar o acesso à posse e propriedade, ou, ao contrário, quanto mais "qualificada" for a posse, tornar-se-á mais difícil constatar e fazer prova dos correspondentes requisitos.

Cremos que não se trataria de outro tipo de posse, mas de posse ativa, objeto de atuação positiva, resultante da atividade realizada sobre o imóvel, em contraposição à posse passiva, objeto de comportamento negativo, na qual não ocorre nem é desenvolvida tal atividade. Para cada uma, em razão da observância de sua função ou não, a lei reserva consequências que podem alterar a situação passiva a favor de outra ativa.

As principais classes nas quais a posse é tradicionalmente estudada são indicadas a seguir $^{271}$.

\footnotetext{
${ }^{270}$ Teori Albino Zavascki. A tutela da posse na Constituição e no Novo Código Civil. Revista Brasileira da Direito Constitucional, p 58-59.

${ }^{271}$ Caio Mario da Silva Pereira também apresenta a sua classificação, conforme segue: (a) justa (nec vi, nec clam, nec precário) e injusta; (b) de boa-fé e de má-fé; (c) posse com justo título, no sentido de causa ou elemento criador de relação jurídica - quem tem um justo título tem para si a presunção da boa-fé; (d) posse ad interdicta (affectio tenendi) e posse ad usucapionem, neste último caso, é necessário que haja a boa-fé (justo título), que seja mansa e pacífica, e o decurso do tempo, cum animo domini; (e) posse direta e posse indireta, sendo que a primeira ocorre com a utilização da coisa por outrem, "para que a coisa possuída
} 


\subsection{JUSTA E INJUSTA}

Conforme o artigo 1.200 do Código Civil de 2002 e o ensinamento de Gonçalves ${ }^{272}$, posse justa é aquela que não é violenta, clandestina ou precária, ou seja, "isenta de vícios, aquela que não repugna ao direito, por ter sido adquirida por algum dos modos previsto na lei”. Por outro lado, posse injusta é aquela adquirida por violência (não necessariamente de máfé, mas por meios violentos, físicos ou morais, de forma que "a violência estigmatiza a posse, impedindo que a sua aquisição gere efeitos no âmbito do direito"), clandestinidade (ocorre quando um objeto é furtado ou um imóvel ocupado às escondidas, de forma oculta, furtiva e subreptícia) ou abuso do precário (que ocorre quando cessa o prazo do contrato pelo qual a posse foi transmitida, mas o bem não é retornado $)^{273}$.

Ensina Gonçalves que "os três vícios mencionados correspondem às figuras definidas no Código Penal com roubo (violência), furto (clandestinidade) e apropriação indébita (precariedade)". Com relação à posse justa e injusta, a verificação é feita pelo critério objetivo, examinando-se a existência ou não dos vícios (vis, clam, precario). A posse justa é necessária para possibilitar as ações interditais.

Também afirma que as hipóteses de vício não foram exauridas pela lei civil, pois, como exemplo, indica aquele que "pacificamente, ingressa em terreno alheio, sem procurar

cumpra a sua finalidade, um deslocamento a título convencional, [ocorre que] então, uma outra pessoa, fundada no contrato, tem a sua posse sem afetar a condição jurídica do proprietário, ou do possuidor antecedente", explicando-se o desdobramento da posse, e "desse desdobramento resulta a duplicidade excepcional da posse sobre a mesma coisa”. Há previsão expressa no artigo 1.197 do Código Civil de 2002. Instituições de Direito Civil - direitos reais, v. IV, p. 22-27.

${ }^{272}$ Carlos Roberto Gonçalves. Direito Civil Brasileiro, Direito das coisas, p. 86.

273 Como crítica ao sistema dos vícios da posse no sistema brasileiro, menciona Marcus Vinicius Rios Gonçalves que melhor teria feito o nosso legislador se tive adotado o mesmo rumo dos Códigos alemão e suíço no tocante à sistematização dos vícios da posse, no sentido de não ter expressamente indicado as hipóteses de posse injusta: "melhor seria que o Código Civil Brasileiro tivesse também optado por uma solução genérica, estabelecendo que a posse é viciosa sempre que oriunda de esbulho, ou seja, sempre que obtida contra a vontade do anterior possuidor, por meios ilícitos. Infelizmente, o novo Código Civil manteve a sistemática antiga, de enumeração dos vícios". Mas ressalta o referido autor que nem por isso o nosso sistema restringiu as situações de posse viciosa aos elementos do aludido artigo 1.200, pois a posse será sim viciosa sempre que obtida por esbulho, mesmo que não enquadrada em alguma das hipóteses do artigo citado. Assim, "a conclusão a que se chega, pois, é que, nem por haver o art. 1.200 do Código Civil, enumerado os vícios da posse, se deixará desprotegido o que foi privado da coisa, por métodos ilícitos". Marcus Vinicius Rios Gonçalves. Dos Vícios da Posse, p. 76-77. 
ocultar a invasão, também pratica esbulho, malgrado a sua conduta não se identifique com nenhum dos três vícios apontados" 274 .

No ensinamento de Marco Aurélio Bezerra de Melo, trata-se de classificação que leva em consideração os chamados vícios objetivos da posse. A posse é injusta quando proveniente de violência - vis -, clandestinidade - clam -, ou precariedade - precario. Já o conceito de posse justa se constrói por negação, ou seja, se a posse não tem os referidos vícios, será justa.

Para referido autor, a posse violenta guarda relação com a figura penal do roubo, enquanto a posse clandestina guarda relação com a figura penal do furto ${ }^{275}$, lembrando ainda que "remanesce com o Código atual a problemática em se fixar com segurança um prazo para a inércia do possuidor agredido em seu direito, o que de certo modo resvala no valor segurança jurídica, mas, por outro lado, analisando-se a posse pela sua imanente função social, permite a lei que o juiz, no caso concreto, certifique se houve ou não a perda da posse por parte de quem se mostrou omisso na defesa do que lhe era próprio, permitindo, desta sorte, a aquisição da posse por quem a tomou violenta ou clandestinamente e deu a ela uma destinação social".

Para Coelho da Rocha, posse justa é a que foi adquirida de maneira permitida pela lei, ou com título legítimo, enquanto a injusta ou viciosa é adquirida de forma ilegal, ou desprovida de título, compreendendo as modalidades vi, clam e precario ${ }^{276}$.

No ensinamento de Washington e do professor Maluf, essa classificação baseia-se na pureza ou nos vícios da posse e encontra definição de posse justa no aludido artigo 1.200 do Código Civil de 2002, como aquela que não foi adquirida de forma violenta (vi, adquirida pela força, com violência inicial; o contrário da posse mansa e pacífica), clandestina (clam, estabelecida subrepticiamente, às ocultas ou escondido de alguém que deveria saber; o contrário da posse pública, gozada na presença de todos) ou precária (recebe a coisa com obrigação de devolver, mas não o faz, ocorrendo abuso de confiança),

\footnotetext{
${ }^{274}$ Carlos Roberto Gonçalves. Direito Civil Brasileiro, Direito das coisas, p. 87.

${ }^{275}$ Marco Aurélio Bezerra de Melo. Direito das Coisas, p. 40-41.

${ }^{276}$ M. A. Coelho da Rocha. Instituições de Direito Civil - tomo II, p. 256.
} 
pois injusta será a posse revestida de um ou mais de tais vícios. Lembram os autores que para que seja passível de defesa, não necessariamente a posse deve ser justa, mas sim justa em relação ao adversário ${ }^{277}$.

Também para Limongi França, “justa é a posse não defesa em lei. Injusta o contrario"278.

No ensinamento de Maria Helena Diniz, sob a ótica da existência de vícios objetivos, a posse justa, que está contida no artigo 1.200, não é violenta (não adquirida pela força física ou por meio de violência moral), nem clandestina (não feita às ocultas de quem pode ter interesse) e nem precária (sem abuso de confiança de quem recebeu com o dever de restituição) $)^{279}$.

Também para Silvio de Salvo Venosa, posse justa é aquela que não apresenta nenhum dos elementos já indicados no próprio Direito romano: Nec vim, nec clam, nec precário. Para a defesa da posse, não é essencial a boa-fé, bastando que a posse não seja violenta, clandestina ou precária ${ }^{280}$.

Continua Silvio de Salvo Venosa que "a posse exige, em princípio, que sua origem não apresente vícios. Posse viciada é aquela cujo vício originário torna-a ilícita". Deve ser feito um exame objetivo - e não subjetivo (da vontade do agente, como seria para a posse de boa ou de má-fé). “(...) Examina-se a injustiça da posse apenas em relação ao adversário"281. Para este autor, as definições de posse violenta, clandestina e precária são as seguintes:

(a) posse violenta: obtida originalmente pela força ou violência, ou mantida desta forma (oposta da posse mansa e pacifica) - basta que seja ofensiva e sem permissão; vem imbuída da má-fé, caracterizada por atos morais (coação moral, vis compulsiva) ou materiais (coação física, vis absoluta).

\footnotetext{
${ }^{277}$ Washington de Barros e Carlos Alberto Dabus Maluf. Curso de Direito Civil, Direito das coisas, p. 40.

${ }^{278}$ R. Limongi França. A Posse no Código Civil (noções fundamentais), p. 16.

${ }^{279}$ Maria Helena Diniz. Curso de Direito Civil Brasileiro, Direito das Coisas, p. 59.

${ }^{280}$ Silvio de Salvo Venosa. Código Civil Comentado Vol. XII - Coordenador Álvaro Villaça Azevedo, p. 57.

${ }^{281}$ Ibid., p. 52.
} 
(b) posse clandestina: obtida às escondidas, ardilmente, escondida de quem tem interesse legítimo.

(c) posse precária: inferior à posse legítima, pois o chamado possuidor se compromete a devolver a coisa após certo prazo, havendo obrigação de restituição, resultando de ato de vontade - havendo o possuidor precarista.

A posse violenta, de acordo com a lei civil portuguesa, surge quando há uso da coação física ou moral. Nesse sentido, a posse pública (é exercida de modo a poder ser conhecida por interessados) contrapõe-se à posse oculta (ocorre sempre que o seu conhecimento não é possível aos interessados; ato clandestino) ${ }^{282}$.

\subsection{DE BOA-FÉ E DE MÁ-FÉ}

Marco Aurélio Bezerra de Melo ensina que boa-fé "é uma situação em que a ignorância do possuidor o absolve das deletérias consequências da má-fé e ainda lhe confere especiais direitos, tais como: percepção dos frutos, indenização das benfeitorias, direito de retenção pelo valor das benfeitorias úteis e necessárias, direito de indenização e retenção por acessões implantadas, possibilidade de utilização da acessão invertida trazida pelo novo parágrafo único do artigo 1.255 do Código Civil, irresponsabilidade pelo dano a que não deu causa, e, ainda, prazos menores para a usucapião de bem móvel e imóvel, dentre outras" 283 .

$\mathrm{O}$ aspecto mais relevante é que a posse de boa-fé gera domínio, além de dar direito aos frutos, eximindo da responsabilidade pela perda ou deterioração da coisa, outorga direito de ressarcimento pelas melhorias realizadas e, ainda, confere regramento à hipótese de edificação ou cultivo pelo possuidor em terreno alheio. Ou seja, a posse de boa-fé é elemento forte na concessão dos mais variados direitos ao possuidor. A posse de boa-fé decorre da consciência de que se adquiriu a posse por meios legítimos ${ }^{284}$, é um dado

\footnotetext{
${ }^{282}$ António Menezes Cordeiro. A Posse: perspectivas dogmáticas actuais, p. 85-102.

${ }^{283}$ Marco Aurélio Bezerra de Melo. Direito das Coisas, p. 41.

${ }^{284}$ Carlos Roberto Gonçalves. Direito Civil Brasileiro, Direito das coisas, p. 94.
} 
psicológico e subjetivo. A verificação é pelo critério subjetivo. A posse de boa-fé será necessária para a ação de usucapião.

Haverá posse de má-fé se houver conhecimento ou consciência do vício ao se adquirir a posse. Também será de má-fé a posse cujo vício é desconhecido por erro inescusável ou ignorância grosseira.

Para Coelho da Rocha, no que se refere à posse de boa-fé, a pessoa tem razões plausíveis para considerar como sua a coisa que possui, ainda que esteja enganado, enquanto na posse de má-fé a pessoa sabe que a posse é viciosa, "ou o deve saber, por não ter título da aquisição, ou presunção dele, ou ser este manifestamente falso" ${ }^{285}$.

Para Menezes Cordeiro, consiste em posse titulada (fundada em qualquer modo legítimo de se adquirir) e posse não titulada, respectivamente. A posse de boa-fé é aquela que surge quando o possuidor ignorava, ao adquiri-la, que lesava o direito de outrem - para o autor, "a boa-fé possessória é ética"; por outro lado, a posse de má-fé ocorre mediante ação culposa para ignorar a violação de direito de outrem ${ }^{286}$.

Conforme disposto no artigo 1.201 do Código Civil de 2002, de boa-fé será a posse se o possuidor tiver a convicção inabalável de que a coisa realmente lhe pertence. A posse de má-fé está viciada por alguns dos elementos que lhe atribuem o caráter de injusta: vi, clam ou precario - tendo conhecimento o possuidor de tais fatos.

Com justo título presente, há presunção de boa-fé, até o momento em que se prove que o possuir não ignora que possui indevidamente, como indica o artigo 1.202 do Código Civil de 2002. A maioria da doutrina acredita que havendo contestação haverá contrariedade, e a posse transformar-se-á em posse de má-fé ${ }^{287}$.

\footnotetext{
${ }^{285}$ M. A. Coelho da Rocha. Instituições de Direito Civil - tomo II, p. 256.

${ }^{286}$ António Menezes Cordeiro. A Posse: perspectivas dogmáticas actuais, p. 85-102.

${ }^{287}$ Washington de Barros e Carlos Alberto Dabus Maluf. Curso de Direito Civil, Direito das coisas, p. 42.
} 
Para Limongi França, a primeira é aquela em que o possuidor ignora o vício ou obstáculo que lhe impede a aquisição da coisa; a segunda é aquela na qual o possuidor conhecia o vício $^{288}$.

Indica Maria Helena Diniz que, sob o aspecto subjetivo, a posse de boa-fé está definida no artigo 1.201, e ocorre "quando o possuidor está convicto de que a coisa, realmente, lhe pertence" (...), sendo ao possuidor com justo título garantida a presunção de boa-fé. Já a posse de má-fé "é aquela em que o possuidor tem ciência da ilegitimidade do seu direito de posse, em virtude de vício ou obstáculo impeditivo de sua aquisição"289.

Lembra Silvio de Sálvio Venosa ${ }^{290}$ que a definição de posse de boa-fé e de má-fé é importante para efeitos da discussão da (i) usucapião; e (ii) percepção dos frutos/benfeitorias, devendo ser analisados os elementos subjetivos, ou seja, a convicção do possuidor (se ele ignora que possuia indevidamente). Nesse sentido, "não basta ao possuidor assentar-se sobre um terreno que se encontra desocupado, sem investigar se existe dono ou alguém de melhor posse. Tão somente a atitude passiva do agente não pode caracterizar boa-fé, porque é curial que ao homem médio incumbe verificar ordinariamente se a coisa tem outro titular”. Desta forma, “(...) em matéria de posse não se configurará a posse de boa-fé quando a ignorância derivar de circunstancias facilmente perceptíveis pelo comum dos homens".

Ao definir a posse de má-fé, afirma que "é aquela na qual o possuidor sabe ter a coisa consigo indevidamente; tem ciência do vício ou do obstáculo impeditivo"291.

Por outro lado, havendo justo título, a boa-fé é presumida (art. 1.201, parágrafo único, do Código Civil).

\subsection{DIRETA E INDIRETA}

\footnotetext{
${ }^{288}$ R. Limongi França. A Posse no Código Civil, p. 16.

${ }^{289}$ Maria Helena Diniz. Curso de Direito Civil Brasileiro, v. 4, direito das coisas, p. 60.

${ }^{290}$ Silvio de Sálvio Venosa. Código Civil Comentado, vol. XII, p. 57-58.

${ }^{291}$ Ibid., p. 60.
} 
Marco Aurélio Bezerra de Melo ensina que, por termos adotado em nosso Código Civil a teoria objetiva de Ihering (que, em linhas gerais considera ser a posse a exteriorização da propriedade), seria possível conceber o desdobramento da posse entre duas pessoas. Uma exercendo a posse direta - a que mantém o contato físico com a coisa - e outra, a posse indireta - a pessoa que desdobrou temporariamente a sua posse $\mathrm{e}^{292}$.

Para Maria Helena Diniz, com base na doutrina de Ihering, ocorreu no nosso sistema jurídico o desdobramento da posse no que concerne ao seu exercício (proprietário concede a posse a outro, mantendo os poderes inerentes ao domínio). "Há duas posses paralelas e reais: a do possuidor indireto que cede o uso do bem e a do possuidor indireto que o recebe, em virtude de direito real, ou pessoal, ou de contrato (...) somente a teoria objetiva de Ihering possibilitaria esse desdobramento, pois para que haja posse basta que se proceda com relação ao bem como o faz o proprietário, já que a posse é a visibilidade do domínio. Assim, o possuidor direito, que o recebe numa destinação econômica, utiliza-o como faria o proprietário" 293 .

As posses direta e indireta sempre coexistem, sendo a direta concedida em todos os casos a título temporário, consistindo em relação jurídica transitória.

Nesse sentido, o artigo 1.197 do Código Civil determina que "a tradição da coisa faz com que se opere a bipartição da natureza da posse".

Deve, portanto, haver "coexistência de direitos diversos sobre uma mesma coisa (...)", implicando a posse direta "sempre uma apreensão efetiva da coisa, enquanto a indireta, a rigor, se considera tal porque é assim admitida pelo sistema. Por isso já se tem aventado mesmo a ideia de ser a posse indireta uma ficção jurídica" ${ }^{294}$.

\footnotetext{
${ }^{292}$ Marco Aurélio Bezerra de Melo. Direito das Coisas, p. 35.

${ }^{293}$ Maria Helena Diniz. Curso de Direito Civil Brasileiro, v. 4, direito das coisas, p. 54-55.

${ }^{294}$ R. Limongi França. A Posse no Código Civil, p. 16.
} 
Assevera Silvio de Salvo Venosa que a divisão em posse direta e indireta "foi a solução encontrada pela lei para contornar situação em que o simples exame do animus e do corpus mostrou-se insuficiente" 295 .

No ensinamento de Washington e do professor Maluf, "todas as vezes que o direito ou a obrigação de possuir caiba a outra pessoa que não o proprietário, a posse se desdobra e se apresenta sob duas faces, sendo direta para o que detém materialmente a coisa, e indireta para o proprietário, para o que concedeu ao primeiro o direito de possuir". A situação possessória é então desdobrada. A posse direita tem caráter temporário, por força do artigo 1.197 do Código Civil de 2002; o principal efeito da posse direta é possibilitar a sua defesa com os interditos possessórios - o possuidor direto pode intentar ação possessória até contra o próprio possuidor indireto ${ }^{296}$.

A regra do Digesto (L. 41, T. 1.1.3, §5º impossibilitava a subdivisão da posse: plures eamdem rem in solidum possidere non possund; contra naturam quippe est, ut, quun ego aliquid teneam, tu quoque id tenere videaris, ou, na tradução de Gonçalves, "muitas pessoas não podem possuir a mesa coisa in solidum" ${ }^{297}$. Esse foi o fundamento adotado por Savigny e seus seguidores, para justificar a posse como aquela que se detém enquanto existir a vontade de proprietário (animus domini, animus rem sibi habendi), não nos casos de detenção (como nos casos do locatário, do comodotário e do depositário).

Sabemos também que Ihering insurgiu-se contra essa visão, afinal, para ele, também são possuidores o locatário, o comodatário e o depositário, uma vez que esses também são protegidos na sua posse.

Assim, surge o desdobramento da posse plena em posse direta e posse indireta, podendo, como lembra Gonçalves, "haver desdobramentos sucessivos”. Essa dinâmica é compatível apenas com a doutrina de Ihering. Indica Gonçalves: "observe-se que o ato de locar, de dar a coisa em comodato ou em usufruto, constitui conduta própria de dono, não implicando a perda da posse, que apenas se transmuda em indireta". Por isso, ambas, direta e indireta,

\footnotetext{
${ }^{295}$ Silvio de Salvo Venosa. Código Civil Comentado Vol. XII, p. 33.

${ }^{296}$ Washington de Barros e Carlos Alberto Dabus Maluf. Curso de Direito Civil, Direito das coisas, p. 38.

${ }^{297}$ Carlos Roberto Gonçalves. Direito Civil Brasileiro, Direito das coisas, p. 79.
} 
têm a mesma qualidade e são jurídicas. Lembra Gonçalves que a questão da qualificação surge apenas quando da diferenciação entre posse justa e injusta e posse de boa-fé e má-fé (arts. 1.200 e 1.201 do Código Civil de 2002) ${ }^{298}$. A vantagem do desdobramento da posse é que ambos os possuidores, direto e indireto, podem invocar a proteção possessória contra terceiro.

A posse direta é também chamada de posse derivada.

Apesar de indicar apoio à visão de Savigny, na prática Wollf acaba admitindo o desdobramento da posse em mediata e imediata ${ }^{299}$. Assim, a posse mediata existe pela mediação da posse de outro, ou seja, "entre o possuidor mediato e a coisa existe a intermediação daquele que detém a posse mesma”, chamando este intermediário de "mediador possessório" ou "subpossuidor". Por sua vez, o possuidor mediato será o "possuidor superior". Contrariamente, aquele que possui sem um "mediador possessório" será o possuidor imediato. A existência da posse mediata pressuporia a existência de uma relação entre o "possuidor superior" e o "subpossuidor"; tal relação poderia ocorrer mediante a celebração de um título, para que se caracterizasse a posse imediata, como, por exemplo, "a título de usufrutuário, credor pignoratício, arrendatário, depositário, ou em uma relação semelhante, em virtude da qual está temporariamente facultado ou obrigado pela posse frente ao outro”. De tal relação jurídica surge também a pretensão do possuidor mediato de restituição da coisa pelo "possuidor mediador".

Não deixa de indagar Wolff se esta situação por si (do possuidor mediador) levaria à existência de uma espiritualização do conceito de senhorio sobre a coisa. No entanto, apesar de haver a posse imediata (interposta entre a coisa e o possuidor superior), esta sempre será uma relação de fato momentâneo, e nunca uma expectativa de propriedade futura. Para Wolff, a entrega da coisa a título de arrendamento e locação, entre outros, não representa uma renúncia à propriedade, mas apena uma atenuação desta. Assim, apesar de na prática não cogitar expressamente do desdobro da posse, Wolff acaba aceitando essa

\footnotetext{
${ }^{298}$ Carlos Roberto Gonçalves. Direito Civil Brasileiro, Direito das coisas, p. 80-82.

${ }^{299}$ Martin Wolff. Tratado de Derecho Civil, Tomo Terceiro - Derecho de Cosas, V. I, p. 43.
} 
ocorrência, pois ao invés de a posse ser desdobrada, indica Wolff que o subpossuidor exerce a posse por força do título outorgado pelo possuidor superior ${ }^{300}$.

Ao constatar a existência de (a) posse causal (aquela exercida pelo proprietário da coisa) e (b) posse formal (aquela que não coincide com a titularidade do direito de propriedade), a autora portuguesa Paula Costa e Silva indaga se são subtipos ou tipos distintos de posse ${ }^{301}$.

No Brasil, a discussão a respeito de como qualificar a posse derivada, muito comum nos países que seguem a teoria subjetiva, torna-se superada, com a visão de posse desenvolvida por Ihering, pois em nosso país a posse se subdivide em direta e indireta, sendo ambas posses, não causando impacto relevante analisar qual o substrato do animus dos possuidores, pois ambas as posses são legítimas e amparadas pela proteção possessória (ou, como poderia dizer Ihering, o animus está compreendido no corpus).

Há posse (e não posses); e a ela a lei atribui ou indica o acréscimo de circunstâncias laterais para que certas consequências sejam alcançadas; a essa adição pode-se querer atribuir denominações específicas, mas isso por si não indica ou faz concluir que uma nova forma de modalidade de posse nasceu: a posse ali já estava.

\subsection{PRÓPRIA E IMPRÓPRIA}

Posse natural é a posse jurídica que se assenta na detenção material e efetiva da coisa; posse civil é a que assim se considera por força de lei, sem necessidade de apreensão material, como no constituto possessório (“A vende sua casa a B, mas continua no imóvel como inquilino; não obstante B fica sendo possuidor da coisa, mesmo sem jamais tê-la ocupado fisicamente, em virtude da cláusula constituti”) $)^{302}$.

\footnotetext{
${ }^{300}$ Martin Wolff. Tratado de Derecho Civil, Tomo Terceiro - Derecho de Cosas, V. I, p. 43.

${ }^{301}$ Paula Costa e Silva. Posse ou Posses?, p. 10.

${ }^{302}$ R. Limongi França. A Posse no Código Civil, p. 18.
} 
A posse natural constitui-se pelo poder de fato sobre a coisa enquanto a posse civil ou jurídica constitui-se por força de lei, prescindido de atos físicos ou de apreensão material, como no constituto possessório; é adquirida por força do título ${ }^{303}$.

\subsection{ORIGINÁRIA E DERIVADA}

Sabemos que Savigny criou o conceito de posse derivada a fim de acomodar o poder detido pelo credor (o precarista e o depositário) para a defesa da coisa, uma vez que em Roma eles não contavam com ação própria, de forma que o pretor assegurava a proteção possessória, como exceção à regra.

Ensina Senise Lisboa que a posse é adquirida originariamente pela apreensão, enquanto os modos derivados de aquisição da posse são a disposição da coisa, o exercício de um direito real e a transmissão da posse, pela traditio brevi manu e pelo constituto possessorio ${ }^{304}$.

A forma derivada ocorreria com o fâmulo da posse (besitzdiener) que é "aquele que, em razão de sua situação de dependência em relação a uma outra pessoa (o proprietário, besitzherr), exerce sobre a coisa não um poder próprio, mas o poder de fato desta última, ${ }^{, 305}$. Existem atos que não levam à posse (como os de mera tolerância ou permissão), pois ausente na pessoa a affectio tenendi da posse ad interdicta e o animus domini da posse ad usucapionem - ou seja, não há direito próprio sobre a coisa.

\subsection{AD INTERDICTA E AD USUCAPIONEM}

Marco Aurélio Bezerra de Melo ensina que a posse ad interdicta "atribui ao titular a possibilidade de utilização dos interditos possessórios que são mecanismos de tutela da posse" 306 . Por sua vez, "a posse ad usucapionem tem que trazer consigo o elemento subjetivo do animus domini materializado na expressão 'possuir como seu' (art. 1.238 do

\footnotetext{
${ }^{303}$ Carlos Roberto Gonçalves. Direito Civil Brasileiro, Direito das coisas, p. 102.

${ }^{304}$ Roberto Senise Lisboa. Manual de Direito Civil, p. 90.

${ }^{305}$ Tito Fulgêncio. Da posse e das ações possessórias. Vol. I, p. 15.

${ }^{306}$ Marco Aurélio Bezerra de Melo. Direito das Coisas, p. 46-47.
} 
CCB), além de ter que ser sem oposição, ininterrupta e incidir sobre bem usucapível durante determinado período de tempo".

No ensinamento de Limongi França, a posse ad interdicta pode ser defendida pelos interditos, enquanto a ad usucapionem pode levar à propriedade ("a posse de um sujeito que se assenhoreia de uma res nullius, detendo-a mansa e pacificamente durante certo tempo") ${ }^{307}$.

Indica Maria Helena Diniz que, quanto aos efeitos, a posse ad interdicta ampara-se nos interditos (ações possessórias), nas hipóteses de ameaça, turbação, esbúlho, ou perda; já a ad usucapionem pode dar origem à usucapião de coisa ${ }^{308}$.

Define Venosa que a posse ad interdicta é aquela passível de ser defendida pelas ações possessórias, possibilitando o uso dos interditos para repelir ameaça, mantê-la ou recuperá$1 \mathrm{a}^{309}$, enquanto a posse ad usucapionem consiste na posse hábil para se obter a propriedade. Também para Washington e para o professor Maluf, a posse ad interdicta é aquela posse no sentido técnico, que pode ser protegida pelos interditos, enquanto a posse ad usucapionem é aquela posse que se prolongou no tempo e que pode dar origem a outros direitos, como o de propriedade ${ }^{310}$.

Assim, temos que a posse ad interdicta é defendida pelos interditos e não leva à aquisição prescritiva; é a posse do locatário, por exemplo, que pode ser defendida pelas ações possessórias, mas não gerará direito aquisitivo. Para ser defendida, basta, portanto, que seja justa, livre dos vícios da violência, clandestinidade ou precariedade); e a posse ad usucapionem "é a que se prolonga por determinado lapso de tempo estabelecido na lei, deferindo ao seu titular a aquisição do domínio"311 , gerando o direito de propriedade. Além dos elementos da posse, necessário haver o decurso do tempo legalmente exigido, o exercício da posse mansa e pacífica, o animus domini, além da boa-fé e do justo título no caso da usucapião ordinária do artigo 1.242 do Código Civil.

\footnotetext{
${ }^{307}$ R. Limongi França. A Posse no Código Civil, p. 17.

${ }^{308}$ Maria Helena Diniz. Curso de Direito Civil Brasileiro, v. 4, direito das coisas, p. 62.

${ }^{309}$ Silvio de Salvo Venosa. Código Civil Comentado Vol. XII, p. 63.

${ }^{310}$ Washington de Barros e Carlos Alberto Dabus Maluf. Curso de Direito Civil, Direito das coisas, p. 43.

${ }^{311}$ Carlos Roberto Gonçalves. Direito Civil Brasileiro, Direito das coisas, p. 103.
} 


\subsection{NOVA E VELHA}

No Código Civil de 1916, havia previsão no artigo 508 no sentido de que se a posse fosse de mais de ano e dia, o possuidor poderia ser nela mantido sumariamente, até ser provado que seu título era pior nas vias ordinárias. Assevera Marco Aurélio Bezerra de Melo que "o citado artigo não foi reproduzido no Código Civil atual por possuir um indisfarçável conteúdo processual, estando hoje disciplinado no artigo 924 do Código de Processo Civil, que estabelece procedimento mais célere para a hipótese de posse nova, com a possibilidade de antecipação de tutela, quando se tratar de ação possessória intentada pelo possuidor em menos de ano e dia da data da turbação ou esbulho" ${ }^{\text {312. }}$.

Ensina Limongi França que “(...) se a turbação ou violência datar de menos de ano e dia, o possuidor lesado poderá requerer mandado de manutenção ou de reintegração initio litis $^{, 313}$.

Define Maria Helena Diniz que a posse de força nova é aquela que se caracteriza com menos de ano e dia, sendo cabível liminar para sua recuperação incontinenti. Por sua vez, a posse de força velha é caracterizada com mais de ano e dia. Esclarece esta autora que "esse prazo é importante porque contra a posse nova pode o titular do direito lançar mão do desforço imediato (CC art. 1.210, par. 1), ou obter a reintegração liminar em ação própria (CPC arts. 926 e s.) ou, ainda a concessão da tutela antecipada. Entretanto, se velha for a posse, o possuidor terá a proteção dos interditos possessórios, até que o órgão judicante o convença da existência de um direito melhor do que o seu', 314 .

Para Venosa, a posse nova é a posse de menos de ano e dia. "O artigo 924 do CPC confere a possibilidade de concessão de liminar initio litis ao possuidor despojado ou ameaçado em sua posse quando intentada a ação dentro de ano e dia da turbação ou esbulho. Passado esse prazo, o rito procedimental será o ordinário, não perdendo, contudo, o caráter

\footnotetext{
${ }^{312}$ Marco Aurélio Bezerra de Melo. Direito das Coisas, p. 46.

${ }^{313}$ R. Limongi França. A Posse no Código Civil, p. 17.

${ }^{314}$ Maria Helena Diniz. Curso de Direito Civil Brasileiro, v. 4, direito das coisas, p. 62.
} 
possessório" ${ }^{315}$. Como mencionado, isto também estava contido nos artigos 507 e 508 do Código Civil anterior. O atual Código não reproduziu o artigo 508, e isto leva ao entendimento de Silvio de Salvo Venosa: "Esses aspectos circunstanciais não são mais enunciados no atual Código Civil. No caso concreto, caberá ao juiz avaliar a melhor posse, e esse enunciado do ordenamento passado pode servir de ponto de partida". Contrariamente, a posse velha é posse de mais de ano e dia.

Desta forma, o decurso do prazo de ano e dia tem "condão de consolidar a situação de fato, permitindo que a posse seja considerada purgada dos defeitos" ${ }^{\text {,316 }}$. Lembra ainda Carlos Roberto Gonçalves que o artigo 1.211 do Código Civil não repediu o prazo de ano e dia indicado no Código de 1916, nem os critérios para se chegar à melhor posse, cabendo ao “juiz, em cada caso, avaliar a melhor posse, assim considerando a que não contiver nenhum vício”. Mas o prazo de ano e dia permanece no Código de Processo Civil para possibilitar a concessão pelo juiz de liminar initio litis (passado o prazo, continuará a ser ação possessória, mas de rito ordinário).

\subsection{POSSE-TRABALHO}

Posse-trabalho, pro labore ou produtiva é aquela "obtida mediante prática de atos que possibilitem o exercício da função social da propriedade", em razão de existir construção para moradia ou investimento econômico ${ }^{317}$.

No ensinamento de Miguel Reale, coordenador responsável pelo Código Civil vigente, "em virtude do princípio de socialidade, surgiu também um novo conceito de posse, a posse-trabalho, ou posse "pro labore", em virtude da qual o prazo de usucapião de um imóvel é reduzido, conforme o caso, se os possuidores nele houverem estabelecido a sua morada, ou realizado investimentos de interesse social e econômico. Por outro lado, foi

\footnotetext{
315 Silvio de Sálvio Venosa. Código Civil Comentado, vol. XII, p. 65. Continua referido autor sobre a origem histórica deste prazo: "há noticia de que o prazo estaria relacionado com o plantio e as colheitas, que geralmente levam um ano".

${ }_{316}$ Carlos Roberto Gonçalves. Direito Civil Brasileiro, Direito das coisas, p. 101.

${ }^{317}$ Maria Helena Diniz. Curso de Direito Civil Brasileiro, v. 4, direito das coisas, p. 62.
} 
revisto e atualizado o antigo conceito de posse, em consonância com os fins sociais da propriedade",318.

Em sentido mais estrito, para Torres, a posse-trabalho pode ser entendida com o conceito de lugar de que a pessoa necessita para morar e plantar para sua subsistência - ou seja, ter atendido o mínimo necessário para a manutenção da dignidade da pessoa. Daí ser a posse "instrumento essencial de satisfação de necessidades humanas, seja ela exercida em razão da titularidade ou não, atendendo a direitos fundamentais". O artigo $6^{\circ}$ da Constituição Federal considerou como direito social fundamental a moradia e o trabalho, abrangendo a posse-moradia e a posse-trabalho ${ }^{319}$. É então considerado direito fundamental o acesso à moradia e ao trabalho (na terra), o que muitas vezes apenas se viabiliza através da posse, que dá efetividade aos princípios constitucionais. A posse então caba sendo o veículo, a ponte que une a pessoa aos meios básicos de sua existência com dignidade, que é garantida pela Constituição Federal. Nesse sentido, ainda segundo o referido autor, a posse-trabalho contribui também para a erradicação da pobreza e formação de um sociedade mais justa e solidária.

Sabemos que Miguel Reale buscou introduzir em nosso Código Civil de 2002 o principio da socialidade, incluindo alternativas viabilizadoras da aquisição da propriedade a favor dos menos favorecidos economicamente. Para Senise Lisboa ${ }^{320}$, "segundo Miguel Reale, a lei civil modificou o conceito de posse, a ela agregando a noção de posse pro labore, por meio da qual se permite a redução do prazo de usucapião de imóvel pelo estabelecimento de moradia no local ou mesmo por investimentos sociais ou econômicos" 321 .

Continua Senise Lisboa: "resta, porém, uma pergunta: será suficiente o aperfeiçoamento pelo legislador de 2002 às formas de aquisição da propriedade e à defesa da posse?”. E responde Senise: "creio que não". Sugere, então, que "vias alternativas seguras devem ser colocadas para que a distribuição de bens seja oferecida realmente a todos, observada a capacidade patrimonial de cada pessoa". Isso porque os mandamentos constitucionais

\footnotetext{
${ }^{318}$ Miguel Reale. Visão Geral do Projeto de Código Civil.

${ }^{319}$ Marcos Alcino de Azevedo Torres. A propriedade e a posse. Um confronto em torno da Função Social, p. 309.

${ }_{320}$ Roberto Senise Lisboa. Manual de Direito Civil, p. 47.

${ }^{321}$ Senise Lisboa chega a afirmar que isso faz o Livro de Direito das Coisas o mais avançado do Código Civil de 2002.
} 
identificados como objetivos republicanos apenas seriam alcançados quando assegurado um patrimônio mínimo a cada pessoa, culminado com a redução das desigualdades sociais.

Assim, nas palavras do próprio Miguel Reale ao se manifestar sobre o projeto do Código Civil: “daí a ideia que tive de inserir no Código, o conceito de 'posse-trabalho', expressão que empreguei, pela primeira vez, ao analisar o projeto de decreto-lei sobre terras devolutas, do Estado de São Paulo, em 1943, quando membro do Conselho Administrativo. 'Posse-trabalho' é a posse socialmente qualificada, isto é, a posse que, além do exercício de fato de uma das faculdades inerentes à propriedade, consubstancia uma efetiva utilização da coisa, para fins sociais, de moradia, educação ou produção econômica. É a construção de uma casa, ainda que modesta, para que nela habite o possuidor com sua família; é uma roça, um serviço de irrigação, uma fábrica, uma escola, uma forma qualquer de investimento social que dá nascimento à posse trabalho, marcando a passagem da compreensão individualista para a concepção social da propriedade"322. Continua referido autor dispondo que nas hipóteses em que a posse se une ao trabalho ocorre o fenômeno da redução dos prazos da usucapião para limites mínimos, tornando-se mais que a exteriorização abstrata de um direito, para se tornar a "concretização viva de uma projeção humana".

Destaca Luiz Edson Fachin a introdução da posse-trabalho feita por Miguel Reale, no âmbito do parágrafo $4^{\mathrm{o}}$ do art. 1.228 do Código Civil de 2002, que tem sido designada de desapropriação judicial, destacando ser este um dos parágrafos que Miguel Reale indicou como inovação na nova codificação, não fica esclarecido, todavia, qual ente governamental deverá arcar com a indenização, dependendo de lei a regulamentar tal dispositivo ${ }^{323}$.

Para Senise Lisboa $^{324}$, dentro da classificação da posse temos posse pro labore e posse improdutiva. Desta forma, a posse pro labore, baseada nos conceitos de Miguel Reale para o Código Civil de 2002, que procurou privilegiar a posse de imóvel obtida a partir da realização de uma atividade laboral, é a posse produtiva, ou posse-trabalho, na qual a

\footnotetext{
${ }^{322}$ Miguel Reale. Anteprojeto do Código Civil, Revista de Informação Legislativa, p. 18.

${ }^{323}$ Luiz Edson Fachin. Revista da EMERJ - Escola da Magistratura do Estado do Rio de Janeiro. Direito das Coisas, p. 141.

${ }^{324}$ Roberto Senise Lisboa. Manual de Direito Civil, p. 85.
} 
pessoa confere função social ao imóvel, em benefício da coletividade. Por outro lado, improdutiva é a posse que se dá sem atender a esse requisito.

\subsection{POSSE EXCLUSIVA E COMPOSSE}

Haverá posse exclusiva quando apenas um possuidor, pessoa física ou jurídica, detiver a posse plena (direta ou indireta).

Contrariamente, a definição de composse abrange o fato de várias pessoas exercerem a posse de uma coisa, ao mesmo tempo, sem que, todavia, ocorra o desdobramento em posse direta e indireta ${ }^{325}$. A posse será exclusiva quando houver um único possuidor; será posse plena, mas poderá ser desdobrada em direta e indireta (pois seja ela direta ou indireta, um só possuidor apresentará os poderes de proprietário). Diferentemente, na composse várias pessoas apresentam poder sobre a coisa, exercendo-o com a vontade do proprietário.

Lembra Gonçalves que "podem os compossuidores (...) estabelecer uma divisão de fato para a utilização pacífica do direito de cada um, surgindo, assim, uma composse pro diviso"; diversamente permanecerá posse pro indiviso se todos exercerem a posse sobre o todo ao mesmo tempo.

Já a posse paralela, ou múltipla, é o caso de sobreposição (concorrência) entre posses, ou ainda, "existência de posses de natureza diversa sobre a mesma coisa" ${ }^{326}$, como no caso de desdobramento da posse em direta e indireta.

$\mathrm{Na}$ composse, duas ou mais pessoas possuem a mesma coisa, mediata ou imediatamente; "dois sujeitos podem ter a posse da mesma coisa como se condôminos fossem" 327. Diferencia-se da composse de mão comum: "nenhum dos sujeitos tem poder fático independente dos demais", como na posse dos herdeiros, em que todos são conjuntamente titulares da posse.

\footnotetext{
${ }^{325}$ Marco Aurélio Bezerra de Melo. Direito das Coisas, p. 37.

${ }^{326}$ Carlos Roberto Gonçalves. Direito Civil Brasileiro, Direito das coisas, p. 85.

${ }^{327}$ Silvio de Salvo Venosa. Direitos Reais, p. 59.
} 
A composse simples se daria, portanto, nas hipóteses em que cada compossuidor tivesse a posse independentemente dos demais, como no caso de um terreno que foi tomado por diversas pessoas. Um exemplo de Venosa: "assim, se duas pessoas possuem um cavalo, ainda que uma delas detenha parcela mínima de seu valor, ambas podem defender sua posse contra terceiros" ${ }^{328}$.

$\mathrm{Na}$ indicação de Coelho da Rocha, "muitas pessoas podem ter a posse comum de uma coisa em partes moralmente determinadas", como, por exemplo, o caso dos coerdeiros ${ }^{329}$.

Da mesma forma, um compossuidor poderá defender sua posse contra outro compossuidor, na turbação que este tentar contra o exercício do poder de fato do primeiro.

Para Venosa, a posse compartilhada pode ser localizada e individualizada, bastando que os compossuidores concordem com a extensão fática da posse dentro do terreno, passando cada um "a exercer a posse exclusiva sobre o torrão escolhido", desaparecendo a composse. Por isso, afirma que a verdadeira composse é a posse pro indiviso.

A posse em princípio é exclusiva - mas como corolário natural da propriedade, também ocorre a composse. Ensina Caio Mario ${ }^{330}$ que, nas relações externas, comportam-se os compossuidores como se fossem um só sujeito. Mas e a relação interna, na determinação dos respectivos direitos? Todos podem usufruir da coisa, na medida em que não interfiram no exercício do outro. Nesse sentido, ensina Caio Mario que se "um perturbar o desenvolvimento da composse, poderá qualquer dos outros valer-se dos interditos”. Cessa a composse por divisão e pela posse exclusiva de uma parte do todo por um dos possuidores, sem oposição dos demais. Lembra Caio Mario que a composse sobre a propriedade comum do solo e parte de uso de todos em edifícios por planos horizontais (condomínio edilício) é perpétua, "no sentido de que não se extinguirá enquanto existir o prédio como entidade econômica e conjunto útil".

\footnotetext{
${ }^{328}$ Silvio de Salvo Venosa. Direitos Reais, p. 61.

${ }^{329}$ M. A. Coelho da Rocha. Instituições de Direito Civil - tomo II, p. 255.

${ }^{330}$ Caio Mario da Silva Pereira. Instituições de Direito Civil - direitos reais, Vol. IV, p. 27-29.
} 
Enveredando pelo condomínio, indica Whitaker que nenhum condômino tem direito a parte certa e determinada do imóvel, e "nada impede que cada um tenha sobre ele posse firmada"331. É o que denomina de "posse localizada", na qual um determinado condômino pode usar e gozar desta parte como se fosse proprietário exclusivo, apropriando-se ainda dos respectivos frutos e rendas, podendo ainda utilizar-se, em caso de turbação, da proteção possessória, quer "o violador da posse seja um estranho, quer seja outro condômino". Tal posse localizada, no entender de Whitaker, apresenta, também, outros efeitos: (a) na hipótese de partilha, confere preferência ao condômino sobre o local possuído; (b) acima do prazo de trinta anos, pode levar à exclusão da ação divisória, em razão da prescrição; (c) pode até mesmo originar o domínio exclusivo, se provado que o possuidor se conservou de forma mansa e pacífica durante o prazo da usucapião. Nesse sentido, Whitaker indica a possibilidade de usucapião por um dos condôminos em detrimento dos demais, caso haja posse exclusiva sobre todo o imóvel, caso o condômino prejudicado não busque as ações possessórias de divisão, partilha ou reivindicação ${ }^{332}$.

Como regra geral, temos que ninguém por si só pode mudar a causa ou o título de sua posse (nemo si ipsi causam possessionis mutare potest).

\footnotetext{
${ }^{331}$ F. Whitaker. Terras - Divisões e Demarcações, p. 63.

${ }^{332}$ Ibid., p. 64.
} 


\section{TEORIAS SOCIAIS DA POSSE}

Inicialmente, podemos destacar que Senise Lisboa divide das teorias explicativas da posse em dois campos ${ }^{333}$, o ontológico e o funcional, como trataremos a seguir:

(a) ontológico:

(a.i) teoria subjetiva. Aposse é entendia como direito subjetivo consistente no poder de atuação da vontade, validado pelo ordenamento jurídico, desenvolvida por Savigny e criticada por Ihering, por desconsiderar que pessoas incapazes também têm direitos, embora não tenham uma vontade juridicamente válida; a posse seria então um direito subjetivo em que há atuação da vontade sobre uma coisa. Há que estar presente o corpus (apreensão) e o animus tenendi (a intenção de ter a coisa), qualificada pela intenção de têla como dono (animus sibi habendi). Nesse sentido, a simples detenção não configura posse, mas sim naturalis possessio, e, destarte, desprovida da proteção possessória, sendo este o grande inconveniente dessa teoria; e

(a.ii) teoria objetiva. A posse decorre de fato jurídico e por isso é um direito, devendo estar presente o corpus (apreensão) e o animus tenendi (desejo de ter a coisa); assim, deixa de lado a discussão sobre a detenção e também a "questão da existência ou não do ânimo de ter a coisa como proprietário".

(b) funcional (função social da posse e função econômica da posse). A posse analisada sob o prisma social ou econômico.

(b.i) função econômica da posse. Adotada por Raymond Saleilles, a posse corresponde à utilização econômica do bem, indo além da teoria objetiva, havendo a relação consciente e desejada da apropriação econômica da coisa.

(b.ii) função social da posse. Sobreveio à teria social "a fim de justificar a eventual retirada ou supressão da posse ou da propriedade, para promover a redistribuição de bens".

${ }^{333}$ Roberto Senise Lisboa. Manual de Direito Civil, p. 64-72. 
Lembrando Senise o ensinamento de Perozzi, indica que a posse é a relação de fato amparada no costume social de "absterem-se todos de uma coisa (...) em respeito à paz social", pois "aquele que tem a plena disposição sobre uma coisa pode se insurgir contra quem quer que se abstenha do bem". E também apoia-se na lição de Fachin, no sentido de que "não há diferença fundamental entre o possuidor proprietário e o possuidor não proprietário; (...) a posse assume uma perspectiva de concessão a uma necessidade”. Assim, resume Senise que a posse deve ser compreendida por seu sentido finalístico de satisfação das necessidades, para obtenção de patrimônio mínimo, amparada pelo princípio constitucional da proteção da dignidade humana; ou seja, "a posse deve ser protegida, sempre levando-se em consideração o solidarismo, objetivo constitucional a ser alcançado".

No mesmo sentido, Bruno Giancoli ${ }^{334}$ indica as seguintes teorias sociais para a posse:

(a) Teoria Social da Posse, de Silvio Perozzi, em sua obra Instituzioni di dirito romano. Indica que a posse corresponde ao "comportamento passivo dos sujeitos integrantes da coletividade com relação ao fato, ou seja, a abstenção de terceiros com relação à posse", sendo a posse "um fenômeno social de gênese e natureza consuetudinárias", um produto da sociedade, que independeria do aparato do Estado.

De fato, ensina Perozzi ${ }^{335}$, na sua visão da posse como fenômeno social, que os homens que atingem um certo grau de civilidade se abstêm de intervir arbitrariamente em coisas que aparentemente não estejam livres, que se encontrem, portanto, em condições visíveis tais que se possa presumir que alguém tem intenção de dispor da mesma coisa com exclusividade.

Em razão desse costume, que vem sendo adquirido e lapidado com o tempo, aquele que tiver manifestado a intenção de que as outras pessoas se abstenham, respeitando a sua disposição exclusiva, não encontrando nenhuma resistência na conduta dos outros, adquire um "poder" que, para Perozzi, corresponde à posse, definindo-a como a plena disposição

\footnotetext{
${ }^{334}$ Bruno Giancoli. Direito Civil, p. 362.

335 Silvio Perozzi. Istituzioni di Diritto Romano, p. 825-831.
} 
de fato de uma coisa, com dois elementos que a compõe: uma vontade e a presença de condições citadas que a propiciem.

Para Perozzi, a posse apresenta, assim, dois elementos, como o domínio: um aspecto negativo, que consiste na abstenção de todos os terceiros com relação à coisa; e um aspecto positivo, que consiste na plena liberdade de ação que resulta da abstenção dos demais.

Assim, na visão de Perozzi, a posse é um estado, ou uma relação permanente, capaz de durar indefinidamente, até que não ocorram circunstâncias que façam cessar tal relação. A posse se adquire e se perde e entre os dois momentos subsiste. Desta forma, o progresso da civilização, resultando em uma sempre maior observação do costume de se respeitar as coisas alheias, resulta em uma posse cada vez mais estável. Para Perozzi, a posse não é uma relação de direito, mas uma situação de fato; a vontade do Estado não faria parte de sua constituição: "trata-se de uma relação ético-social, enquanto tem por base um hábito, que faz parte da moralidade social" ${ }^{336}$.

A posse é um poder "real", porque é um poder sobre a coisa, e também é uma relação entre os homens. A liberdade de ação sobre uma coisa é uma liberdade "social" de ação.

Como mencionado anteriormente, para Perozzi, a posse se parece com a propriedade na medida em que ela também é uma propriedade; mais precisamente, uma "propriedade social”, um estado de liberdade de ação relacionado à coisa vigente por forças sociais.

Perozzi, conforme o ensinamento de Moreira Alves, desenvolve, a partir de 1906, esta teoria social da posse, ou a posse como fenômeno social. Abstraindo as lições de Perozzi, Moreira Alves também ressalta a tendência dos homens deixarem de intervir de forma arbitrária em coisas que aparentemente não estejam livres. Estabelece-se o costume nesse sentido, e aquele que manifesta essa intenção que todos os demais de abstenham da coisa, não encontrando resistência, "se investe de um poder sobre ela que se denomina posse. (...)

${ }^{336}$ Silvio Perozzi. Istituzioni di Diritto Romano, p. 830. 
E a posse se torna tanto mais estável quanto mais esse costume social de abstenção é observado como decorrência do progresso da sociedade",337.

Assim, para Perozzi a posse se forma em dois momentos, um negativo, calcado no costume social de abstenção de todos os demais, e o outro positivo, consolidado na plena liberdade e disposição sobre a coisa por parte do possuidor. A posse guarda, portanto, muita semelhança com a propriedade.

Nesse sentido, Perozzi alcança uma posição bastante interessante ao estabelecer que a posse é uma propriedade social (mas difere-se da propriedade, pois uma é fato e a outra direito, e também porque a posse obtém lastro do costume social, enquanto a propriedade o obtém do Estado).

Em resumo, no entender de Perozzi, a posse se dá como relação ético-social, baseada no costume que faz parte da moralidade social. Buscando exprimir com um exemplo simples em que a teoria de Perozzi diverge das outras (objetiva e subjetiva), apresenta o famoso caso do chapéu: uma pessoa passeia pela rua com o chapéu na cabeça; nessa situação temos as seguintes visões: (a) segundo a teoria subjetiva (chamada de física pelo autor), a pessoa possui o chapéu porque o tem na cabeça e pode retirá-lo e recolocá-lo, e está pronta para defendê-lo, se outros tentarem tirá-lo; (b) de acordo com a teoria da exterioridade do domínio (objetiva), a pessoa o possui porque quem é proprietário de um chapéu habitualmente o mantém na cabeça e tem a aparência de alguém que seja proprietário desse chapéu; (c) para Perozzi, porém, a pessoa possui o chapéu porque, portando-o na cabeça, demonstra querer dispor exclusivamente dele e, portanto, nenhuma outra pessoa pode tirálo de sua cabeça e este fato da extensão espontânea de seu chapéu às demais pessoas faz com que a sua vontade de que os outros se abstenham de importuná-lo para que ele disponha do chapéu seja respeitada ${ }^{338}$.

(b) Teoria da Apropriação Econômica da Posse, de Raymond Saleilles, em suas obras La Possession e De la possession des meuble, indicando que a posse se manifesta pelo juízo de valor segundo a consciência social considerada economicamente, como um

\footnotetext{
${ }^{337}$ José Carlos Moreira Alves. Posse, V. I. Evolução Histórica, p. 240-241.

${ }^{338}$ Silvio Perozzi. Istituzioni di Diritto Romano, p. 829.
} 
“campo de apropriação individual, fora dos limites do dominum", traduzindo como efetiva e consciente apropriação das coisas, lastreada pela posse-trabalho.

Para Saleilles ${ }^{339}$, no tocante à função social da posse, há uma de fruição entre o homem e o bem, ou uma atitude econômica e social, que constitui a posse. Essa relação tem característica social.

Assim, podemos perceber que Saleilles define a posse como uma situação de fato que, por si mesma, é independente de toda questão de fundo jurídico, pois agrega um valor social e econômico à posse.

Moreira Alves lembra as palavras de Hernandez Gil: "se alguma concepção possessória pode considerar-se, por seu grau de elaboração, como equivalente às de Savigny e de Ihering, tal é, sem dúvida possível, a de Saleilles”. Criou em 1893 a teoria da apropriação econômica, entendendo Saleilles que a posse origina-se da apropriação econômica, e não jurídica. A posse passa a ser a exteriorização da utilização econômica da coisa (e não a exteriorização da propriedade, como defendia Ihering), ou seja, a exploração da coisa a serviço da pessoa. A posse é entendida como a "realização consciente e querida da apropriação econômica das coisas, há um corpus distinto, portanto. A posse se dá não para exteriorizar a propriedade, ou como extensão desta, mas sim para satisfazer a exploração econômica da coisa. Por consequência, também o animus resultará distinto, como o animus possidendi dos romanos, e entre ambos corpus e animus há liame indissolúvel que os une" ${ }^{\natural 40}$. Continua Moreira Alves que, segundo o pensamento de Saleilles, "o critério para distinguir a posse da detenção é o de observação dos fatos sociais; há posse onde há relação de fato suficiente para estabelecer a independência econômica do possuidor”, de forma que os costumes e necessidades econômicas, na medida em que evoluem, criam novas modalidade de posse, que não ficam engessadas ou dependentes da criação legal (como entendia Ihering, no sentido de que todo detentor é possuir, salvo previsão legal em contrário).

\footnotetext{
${ }^{339}$ Raymond Saleilles, De la possession des meuble, p. 5.

${ }^{340}$ José Carlos Moreira Alves. Posse, V. I. Evolução Histórica, p. 236-237.
} 
Saleilles também afirma a posse como elemento social, presente nas relações sociais. Tem uma concepção popular ou social. "São os estados dos costumes, o ambiente do meio, e a evolução da vida social que determina o poder e domínio sobre a coisa, frente a sociedade" ${ }^{341}$. Esta concepção social da posse foi desenvolvida por Saleilles.

Serpa Lopes indica a contribuição de Saleilles feita em 1907 com a publicação de De la possession de meuble, partindo da teoria de Ihering, mas dela divergindo ao não visualizar no corpus um exteriorização de propriedade, mas sim com uma utilização econômica da coisa, a afetação a uma destinação econômica ${ }^{342}$.

Indica Manuel Rodrigues o ensinamento de Saleilles "o conceito de posse não depende, pois, dos elementos objetivos do poder de fato; mas de um elemento que lhe é exterior e ao sujeito da posse - a consciência social. ${ }^{343}$

Por sua vez, Astolpho Rezende ensina que Saleilles tinha, na verdade, uma pequena discrepância conceitual com a teoria de Ihering (manifestação exterior do direito de propriedade), no tocante à definição do corpus possessório. "Para Saleilles, o corpus possessório é a manifestação externa (não do direito de propriedade), mas da exploração econômica da coisa, isto é, um estado de fato tal que revele o senhor de fato da coisa, aquele que a tem sob sua dependência, e fá-la servir a satisfação de suas necessidades (...)". Ou seja, existe "uma relação duradoura de apropriação econômica, uma relação de exploração da coisa a serviço do individuo (...)". Por isso, "a posse é a realização consciente e voluntaria da apropriação econômica da coisa”. Em resumo, ensina Astolpho Rezende, "não é a propriedade, argumenta Salleiles, que se quer proteger através da posse, mas a utilização econômica da coisa; e, por conseqüência, a exploração econômica de um arrendamento é tão digna de proteção, como a correspondente ao direito de propriedade" 344 .

(c) Teoria da Posse como Fenômeno Social, de António Hernández Gil, em sua obra La Possession, sendo a posse a "instituição jurídica de maior densidade social, isso porque

\footnotetext{
${ }^{341}$ Raymond Saleilles, De la possession des meuble, p. 15.

${ }^{342}$ Miguel Maria de Serpa Lopes. Curso de Direito Civil. Direito das coisas. Vol. VI, p. 115.

${ }^{343}$ Manuel Rodrigues. A posse. Estudo de Direito Civil Português, p. 88-89.

${ }^{344}$ Astolpho Rezende. A posse e sua proteção, p. 101-102.
} 
revela a necessidade primária do homem de apropriar-se das coisas que necessita. Enquadra-se na estrutura e na função do Estado social com um programa de igualdade na distribuição dos recursos".

Sobre a função social da posse, citando Hernández Gil, Castan Tobeñas indaga como a posse é hoje afetada diante do inconformismo dos despossuídos, questionado ainda sobre o acesso à posse. Questiona também por quanto tempo o direito continuará a ter papel de polícia perante as reivindicações sociais. Diante de tais questões, indica que há evidentemente razões para inquirir outro significado para a posse, o qual somente será alcançado com a presença da função social. Hernández Gil afasta a hipótese de que venha ocorrendo um declínio da posse, dispondo que há, sim, uma transformação na sua função, com um programa de igualdade e distribuição dos recursos coletivos; o que declina é o velho entendimento da posse, por deixar de responder ao interesse social. Em decorrência, afirma Castan Tobeñas que a posse não pode se restringir às questões de iniciativa pessoal, mas deve ampliar seu âmbito para incorporar valores econômicos ao alcance de $\operatorname{todos}^{345}$. Assim, deve ser encontrada uma fórmula atributiva da utilização das coisas, atendidas as necessidades comuns dos homens ${ }^{346}$.

Hernández Gil propõe-se a apresentar um trabalho não apenas jurídico, mas de investigação jurídica com uma preocupação sociológica. Talvez por essa razão não se limita a analisar e avaliar estruturas jurídicas, mas também questiona desigualdades sociais e apresenta preocupação com os despossuídos. Nesse sentido, rompe com seus antecessores Salleiles e Perozzi, ambos revisitadores dos conceitos romanos, pois não procura entender a posse como instituição jurídica com origens no Direito romano, buscando, por outro lado, seus contornos a partir dos princípios então lançados. Sugere uma visão socializadora da posse, como instrumento a serviço da redistribuição de bens

\footnotetext{
${ }^{345}$ Da mesma forma, no alemão, a origem etimológica palavras betizen (possuir) e besitz (posse) derivam de sitzen (sentar-se ou estar sentado) e do prefixo be, que dá reforço. Jose Castan Tobeñas. Derecho Civil Español, Comun y Foral, p. 653-655.

${ }^{346} \mathrm{O}$ mais interessante é que Hernández traça um paralelo com os então existentes estados socialistas do leste europeu e com a União Soviética, indicando que em uma sociedade socialista a posse se manifesta para corrigir a propriedade estatizante e atua como um reduto da liberdade pessoal, enquanto nos países capitalistas ocorre o contrário: a posse tenderia a ser um corretivo da propriedade privada monolítica, abrindo espaço a um processo socializante.
} 
aos despossuídos, de forma que esses também possam fazer parte da exploração de sua função social.

Para Hernández Gil, a posse seria o direito que mais diretamente influencia a realidade social. Indicam Farias e Rosenvald que, conforme as ideias desenvolvidas pelo autor, "por servir o uso e o trabalho sobre a coisa a necessidades humanas básicas, justifica-se o dever geral de abstenção perante a situação do possuidor e a garantia do desfruto de bens essenciais" 347 .

Fica surpreso Gil com o fato de que a posse, que apresenta aspecto factual tão intenso, acaba sendo estratificada nos Códigos, mostrando que essa estratificação não veio acompanhada da preocupação de como conferir aos despossuídos a posse de elementos que garantam as suas necessidades, destacando as seguintes indagações: "Como repercute na posse o inconformismo dos despossuídos? E o acesso à posse? Pode seguir o direito desempenhando o papel de simples polícia e declarar ato de guerra a qualquer reivindicação social? De tais perguntas, depreende Hernández Gil que se deve buscar uma nova definição para a posse, e que esse novo significado deve partir da função social ${ }^{348}$.

Ainda em 1969, Hernandez Gil propõe com relação à função social da propriedade uma mudança no entendimento de que esta função seria uma limitação ao direito de propriedade (concepção negativa), para o entendimento de que consiste em dever na administração do bem (concepção positiva), de forma que "o proprietário não encontra diante de si simples barreiras (limitações), mas sim formas pré-determinadas de comportamentos que lhe são exigidos. A consequência mais importante que se origina da função social é a ruptura com o conceito unitário do direito de propriedade" ${ }^{\text {349 }}$. Cita ainda que uma maneira de atingir a função social da posse é facilitar o acesso à propriedade imobiliária. A lição de Hernández Gil feita na década de 60 do século XX ainda é valida ao Brasil do século XXI.

Com introdução da função social na equação da posse, "a figura da propriedade estática e formal cede lugar a uma propriedade dinâmica (...), consistindo, em resumo, na posse". Ou

\footnotetext{
${ }^{347}$ Cristiano Chaves de Farias, Nelson Rosenvald. Curso de Direito Civil, p. 75.

${ }^{348}$ António Hernández Gil. La función social de la posesión (ensayo de teorización sociológico-jurídica), p. 91.

${ }^{349}$ Ibid., p. 171.
} 
seja, existem direitos conexos ao direito de propriedade que dizem respeito à sociedade, não incluindo apenas o proprietário, mas também todos os demais que se envolvem na gestão e exploração econômica do bem $^{350}$. Ademais, a posse não mais deveria ficar circunscrita a apresentar-se como a origem ou resultado dos interditos, revelando o referido autor ficar ressentido em ver por um lado a complicada explicação científica da posse e sua tutela, e do outro, a simplicidade de sua realidade.

(d) Teoria da Composição Econômica da Posse, de Francesco Carnelutti, em sua obra Teoria Geral do Direito, considerando a posse um instrumento de tranquilidade social e jurídica, equivalendo a um fenômeno econômico, mas que pode "eventualmente transformar-se em um fenômeno jurídico. Havendo conflito de interesses, um deles se faz prevalecer pela iniciativa de um dos sujeitos, o possuidor que desfruta de um bem”.

Francesco Carnelutti refere-se à composição econômica do conflito que pode advir entre os homens, considerando que os bens que buscam para satisfazer suas necessidades são mormente escassos.

Assim, Carnelutti define a posse como a expressão de uma composição espontânea a que pode convir a designação de composição econômica, este "velho e enigmático instituto" tem origem no conflito de interesse; a posse como composição econômica do conflito. A posse dá tranquilidade à sociedade - mas essa tranquilidade pode de um momento para outro ser perturbada $^{351}$.

Lembra ainda Giancoli que "as teorias sociológicas de Perozzi, Saleilles e Hernández há tempos influenciam a doutrina nacional sobre o tema, tomando como parâmetro o inciso XXIII do art. $5^{\circ}$ e os arts. 183 e 191 da CF/88 como justificativa para a concepção social da posse. Essa postura foi reforçada pelo $\S 4^{\circ}$ do art. 1.228 do Código Civil” ${ }^{352}$.

\footnotetext{
${ }^{350}$ António Hernández Gil. La función social de la posesión (ensayo de teorización sociológico-jurídica), p. 174.

${ }^{351}$ Francesco Carnelutti. Teoria Geral do Direito, p. 93.

${ }^{352}$ Bruno Giancoli. Direito Civil, p. 363.
} 


\section{FUNÇÃO SOCIAL DA POSSE}

Sob a perspectiva do contrato e sua função social, ensina o professor Godoy ${ }^{353}$ que o contrato deve ser funcionalizado à luz de novo paradigma: voltando-se à "promoção dos valores básicos do ordenamento, o que, no Brasil, resta claro da disposição do art. 170, logo no caput, da Constituição Federal, que estabelece, como princípios fundamentais da ordem econômica (...) a dignidade da pessoa humana e a justiça social, e já antes, nos arts. $1^{\circ}$, incisos III e IV, bem como no art. $3^{\circ}$, I, consagrados como princípios fundamentais da República (consistentes nos princípios da dignidade e do solidarismo)”.

Nesse sentido, "os valores sociais da moradia, do trabalho, da dignidade da pessoa humana fazem com que a estrutura normativa da defesa do exercício da propriedade seja assegurada independentemente do domínio. A justificativa da posse encontra-se diretamente na função social que desempenha o possuidor, direcionando o exercício de direitos patrimoniais a valores existenciais atinentes ao trabalho, à moradia, ao desenvolvimento do núcleo familiar". Ainda sobre a função social, ensina Gustavo Tepedino que "como elemento interno do domínio, a função social é responsável pelo controle de legitimidade funcional do direito de propriedade, impondo ao titular o dever de respeitar situações jurídicas e interesses não-proprietários socialmente tutelados, atingidos pelo exercício dominical”,354.

Há uma confluência da dicotomia que para o professor Godoy se revela na perseguição dos objetos do solidarismo e da dignidade humana (função social ou de integração social), de um lado, e de outro, uma função individual, voltada a garantir "condições de desenvolvimento pessoal dos indivíduos". Nesse sentido, o Estado deve estar presente para dirigir certos comportamentos humanos à consecução desses objetivos constitucionalmente $\operatorname{expressos}^{355}$. Parafraseando ainda o ensinamento do professor Godoy, e aplicando-o à

\footnotetext{
${ }^{353}$ Claudio Luiz Bueno de Godoy. Função Social do Contrato, p. 118.

${ }^{354}$ Gustavo José Mendes Tepedino. Os Direitos Reais no Novo Código Civil. Revista da EMERJ - Escola da Magistratura do Estado do Rio de Janeiro, p. 170-172.

${ }^{355}$ Claudio Luiz Bueno de Godoy. Função Social do Contrato, p. 119. Também essa a visão de Farias e Rosenvald: "surge uma tensão entre o direito fundamental individual de propriedade, do art. $5^{\circ}$, XXII, da CF, e o direito subjetivo metaindividual do inciso XXIII. É necessário aprender a conviver com prováveis hipóteses de colisão entre os princípios (...). Esta tensão será solucionada pela lei ou pelo magistrado, na
} 
pretendida função social da posse, sua relevância se dá na promoção dos objetivos do Estado Social, na eficácia dos valores básicos do ordenamento.

Apresenta o professor Maluf que a função social da propriedade urbana está assentada inicialmente no artigo $182, \S 2^{\circ}$, da Constituição Federal ${ }^{356}$ :

\section{Capítulo II - Da Política Urbana}

Art. $182(\ldots)$

$\S 2^{\circ}$ A propriedade urbana cumpre a sua função social quando atende às exigências fundamentais de ordenação da cidade expressas no plano diretor.

Em continuação, a Lei $n^{0}$ 10. 257, de 10 de julho de 2001 (Estatuto da Cidade) determina, em seu artigo 39 (que exatamente dá extensão ao indicativo do aludido art. 182, § $2^{\circ}$, da Constituição Federal), que "a propriedade urbana cumpre sua função social quando atende às exigências fundamentais de ordenação da cidade expressas no plano diretor, assegurando o atendimento das necessidades dos cidadãos quanto à qualidade de vida, à justiça social e ao desenvolvimento das atividades econômicas (...)”.

Mas há que se buscar um equilíbrio entre os princípios constitucionais da propriedade e sua função social. Como aduz José Fernando Lutz com relação à função social, "não se está negando o direito de propriedade, apenas se está introduzindo um interesse preponderante, que corresponde ao interesse da coletividade, em busca de que a propriedade seja um mecanismo de justiça social. Busca-se assim a conciliação do modelo econômico capitalista com uma política social que almeje a reduzir desigualdades e promover a dignidade humana, enquanto princípios e fins da Constituição são norteadores da ação estatal",357.

Indica o professor Maluf a doutrina de Duguit, "para quem a propriedade já não é o direito subjetivo do indivíduo, mas uma função social a ser exercida pelo detentor da riqueza", comportando diversas limitações em beneficio de interesses sociais e da coletividade.

vertente do princípio da proporcionalidade" (Cristiano Chaves de Farias; Nelson Rosenvald. Direitos reais, p. 42).

${ }^{356}$ Carlos Alberto Dabus Maluf. Limitações ao Direito de Propriedade, p. 214.

${ }^{357}$ José Fernando Lutz Coelho. Contratos Agrários. Uma visão neo-agrarista, p. 43. 
Explica, ainda, o professor Maluf que isso "implica a superação da contraposição entre público e privado, isto é, implica a evolução da propriedade em sentido social, numa verdadeira metamorfose qualitativa do direito na sua realização concreta, destinada a satisfação de exigências de caráter social". Em resumo, pontua que a propriedade deixa de ser vista sob o ângulo individualista, para ser entendida em uma perspectiva coletiva ${ }^{358}$.

Já na década de 1940, ensinava Eurico Sodré, abordando o caso da desapropriação, que existiam formas de limitação de um direito, em nome de algo maior de interesse da coletividade, e, portanto, não necessariamente implicava em qualquer violência ou esbulho, mas sim limitação praticada por força e em nome do Direito. Nesse sentido, "o constrangimento imposto ao proprietário não passa de uma das muitas limitações legais do direito individual, mediante as quais se realizam a ordem e o bem estar sociais" ${ }^{\text {"359. }}$.

Em última instância, está-se a defender o bem coletivo e para tanto cada um cede parcela de sua individualidade (de sorte que o direito coletivo restringe o direito individual, lembrando Sodré que isso se verificou em todos os tempos históricos ${ }^{360}$ ).

Nesse mesmo sentido, indica Limongi França que a perda ou limitação da propriedade e da posse, pela desapropriação, funda-se em duas premissas (a) sacrifício do interesse individual em benefício da coletividade (fundado no Direito Natural); assim a plenitude do direito de propriedade perde dimensão entre o benefício da coletividade, aqui manifestado pela desapropriação, quer por necessidade, utilidade pública ou interesse social; e (b) nas normas do Direito Positivo, com o limite de não ser tornar uma "anti-propriedade"361.

Assim, conclui Sodré que basta "observar os fatos da vida cotidiana para ver que a propriedade privada sofre a cada passo imposições restritivas de seu uso, de seu gozo, de sua exploração, de sua disponibilidade. (...) O desenvolvimento que bem tendo o Estado

\footnotetext{
${ }^{358}$ Carlos Alberto Dabus Maluf. Limitações ao Direito de Propriedade, p. 68-71.

${ }^{359}$ Eurico Sodré. A Desapropriação por Necessidade ou Utilidade Pública, p.7-8.

${ }^{360}$ Nesse sentido, o indivíduo não é sacrificado porque se integra na coletividade, mas beneficia-se também, pois o homem nunca está isolado de seu meio. Para Sodré, "o homem, por sua origem e destino, é solidário com seu meio. Está nessa solidariedade, o fundamento moral da desapropriação" ou também das demais limitações ao direito de propriedade, completaríamos nós. A Desapropriação por Necessidade ou Utilidade Pública, p. 13-14.

${ }^{361}$ R. Limongi França. Manual Prático das desapropriações, p. 28.
} 
Previdência, em oposição à do Estado apenas Policial, só se realiza através aquelas restrições e medidas outras que hipertrofiam a função do Estado atrofiando a liberdade individual" ${ }^{362}$.

Baseado no ensinamento de Fachin, indica Senise Lisboa que "não se pode restringir a noção de posse à mera exteriorização da propriedade, noção estreita do liberalismo clássico "pois a posse assume outra perspectiva, a de uma concessão à necessidade da pessoa" ${ }^{363}$. Baseia-se também no ensinamento de Hernández Gil para indicar que a posse apresenta um função social "que deve ser reconhecida pelo ordenamento jurídico porque a legislação tem que corresponder à realidade da sociedade, e quando possível, até mesmo modificar as suas estruturas". Pode ser visto como o instituto que concretiza um dos principais princípios sociais, a outorga de "patrimônio mínimo que possa garantir a dignidade humana".

Ensina Carlos Roberto Gonçalves que "em nosso país, o grande passo na concepção social da posse foi dado com a reafirmação, no inciso XXIII do art. $5^{\circ}$ da Constituição Federal de 1988, do principio de que 'a propriedade atenderá a sua função social', completado pelas regras sobre a política urbana, atinentes à usucapião urbana e rural (arts. 183 e 191)" 364.

No Código Civil, também há essa preocupação com a visão social - nos termos do artigo $1.228 \S 4^{\circ}$, como indica o próprio Miguel Reale com o conceito de posse-trabalho, que pode ser representado na seguinte fórmula:

POSSE $=$ solidariedade como valor coletivo para satisfazer interesses coletivos + salvaguarda dos direitos individuais

Assim, a posse-trabalho deve ser entendida como resultado do trabalho efetuado sobre o imóvel, agregando não só valor, mas provendo às necessidades e dignidade humanas. Havendo isso, justo será pagar a indenização ao proprietário que detinha a titularidade, em observância à Constituição Federal. Também Tartuce e Simão indicam que a função social

\footnotetext{
${ }^{362}$ Eurico Sodré. A Desapropriação por Necessidade ou Utilidade Pública, p 23.

${ }^{363}$ Roberto Senise Lisboa. Manual de Direito Civil, p. 50.

${ }^{364}$ Carlos Roberto Gonçalves. Direito Civil Brasileiro, Direito das coisas, p. 58.
} 
da posse está presente no tratamento da desapropriação judicial privada por posse-trabalho, prevista no art. 1.228, parágrafos $4^{\circ}$ e $5^{\circ}$, do Código Civil de $2002^{365}$.

Já indicava Senise Lisboa a necessidade de se proceder ao redimensionamento da usucapião para além daquilo que já conferido pelo Código de 2002 (com a diminuição dos prazos da usucapião aplicada pelos trabalhos conduzidos por Miguel Reale). Assim, como elementos fundamentais que devem ser buscados para a moderna posse, elenca Senise: (a) o redimensionamento da usucapião; (b) os meios alternativos de utilização de bens, (c) o atendimento à dignidade humana, e (d) a existência de patrimônio mínimo.

Pode-se aplicar à função da posse também o princípio da socialidade indicado pelo professor Godoy. Dele origina-se a função social [do contrato] e busca "retirar a lei civil do individualismo típico do modelo liberal sob cuja influência se elaborou o Código Civil de 1916, forte na proteção das clássicas manifestações do direito subjetivo individual, ou na proteção de seus titulares”366 (como o proprietário, o contratante, o marido, o testador), pretendendo "inserir a normatização civil em novo paradigma, de prestígio dos valores sociais, sem se perder, é certo, o valor fundante da pessoa humana, afinal a origem, centro e finalidade da ordenação".

Acrescenta Gustavo Tepedino sobre a função social e a visão da propriedade na Constituição Federal: “A propriedade, portanto, não seria mais aquela atribuição de poder tendencialmente plena, cujos confins são definidos externamente, ou, de qualquer modo, de caráter predominantemente negativo, de tal modo que até uma certa demarcação, o proprietário teria espaço livre para suas atividades e para a emanação de sua senhoria sobre o bem. A determinação do conteúdo da propriedade, ao contrário, dependerá de centros de interesses extraproprietários, os quais vão ser regulados no âmbito da relação jurídica de propriedade" 367 .

\footnotetext{
${ }^{365}$ Flávio Tartuce, José Fernando Simão. Direito Civil - Direito das Coisas. p. 31.

${ }^{366}$ Claudio Luiz Bueno de Godoy. Função Social do Contrato, p. 121.

367 Gustavo José Mendes Tepedino. Temas de direito civil. Contornos Constitucionais da Propriedade Privada, p. 317.
} 
Desse novo paradigma em que se coloca a legislação civil e constitucional, dá como exemplos muito interessantes o professor Godoy ${ }^{368}$ : (a) o Código Civil de 2002, no artigo 1.238, estabelecendo a usucapião com prazo reduzido; (b) o Código Civil de 2002, nos artigos 1.239 e 1.240, estabelecendo a usucapião especial; e (c) o Código Civil de 2002, no artigo $1.228 \S \S 4^{\circ}$ e $5^{\circ}$, instituindo a proteção da posse-trabalho, também chamada de desapropriação judicial ou pro labore.

Assim, o próprio eixo interpretativo do Código Civil deve deslocar-se, ou foi já deslocado, saindo da perspectiva individualista (como presente no Código de 1916) para que "cumpra um novo papel, de satisfação dos propósitos e valores que o sistema escolheu e protege, no interesse de todos". A própria Constituição Federal fez esse movimento, lembrando que um dos mais importantes fundamentos é a dignidade humana ${ }^{369}$, que pode levar ao acesso de bens e serviços a todos, que deve almejar e propiciar a construção de um projeto de sociedade que busque favorecer a todos. Ensina ainda o professor Godoy que a função social do contrato é uma projeção da função social da propriedade, de onde verdadeiramente se origina. Se a função social do contrato se origina da função da propriedade $^{370}$, com mais razão ainda pode-se considerar que a função social da posse também se origina da função social da propriedade. Assim, nas relações sociais da posse, devem estar presentes o atendimento aos dois princípios constitucionais básicos: a dignidade da pessoa humana e o solidarismo social ${ }^{371}$.

Sobre a função social da propriedade, devemos buscar o ensinamento de Fabio Konder Comparato: “A concepção privatista da propriedade, a que se fez referência no início desta exposição, tem levado, frequentemente, autores e tribunais à desconsideração da verdadeira natureza constitucional da propriedade, que é sempre um direito-meio e não um direito-fim. A propriedade não é garantida em si mesma, mas como instrumento de proteção de valores fundamentais". Assim, para referido autor, em conclusão, "a propriedade foi concebida como um instrumento de garantia da liberdade individual, contra a intrusão dos Poderes Públicos. As transformações do Estado contemporâneo

\footnotetext{
${ }^{368}$ Claudio Luiz Bueno de Godoy. Função Social do Contrato, p. 122.

${ }^{369}$ Ibid., mesma página.

370 A função social da propriedade "vem explícita na Constituição como direito e garantia individual", levando à necessidade de democratizar o seu acesso, também pelo contrato, em vista do artigo $5^{\circ}$, XXIII.

${ }^{371}$ Claudio Luiz Bueno de Godoy. Função Social do Contrato, p. 125-126.
} 
deram à propriedade, porém, além dessa função, também a de servir como instrumento de realização da igualdade social e da solidariedade coletiva, perante os fracos e desamparados"372.

Indica Ana Rita Vieira Albuquerque que "nesse sentido, torna-se evidente que o instituto da posse não pode deixar de receber esse influxo Constitucional [relativo à função social da propriedade e direitos sociais constitucionais], adequando as suas regras à ordem constitucional vigente como forma de cumprir a sua função de instituto jurídico, fruto do fato social em si, verdadeira emanação da personalidade humana e que, por isso mesmo, é ainda mais comprometido com os próprios fundamentos e objetivos o Estado Democrático de Direito e a efetividade do princípio da dignidade da pessoa humana”373.

Assim, o estudo da função social da posse pressupõe que os preceitos e valores constitucionais permeiem a base teórica do Direito Privado e da codificação civil, ainda que não formalizado expressamente, como a função social da propriedade.

Nesse sentido, sobre a função social, Orlando Gomes e Fachin indicam: "não pode mais a tutela da posse ser focalizada somente ao abrigo do Código Civil", uma vez que "assumiu a Constituição de 1988 a missão de conferir estatuto elevado à proteção possessória, sob a luz das regras e princípios concernentes à função social da propriedade”. Com a promulgação da Constituição Federal em 1988, a posse deixa de ser pensada apenas como ponta de lança da propriedade ("guarda avançada da propriedade") sendo entendida como instituto autônomo à propriedade. Citam os referidos autores, nesse sentido, o Enunciado 492 das Jornadas de Direito Civil do Conselho da Justiça Federal: “A posse constitui direito autônomo em relação à propriedade e deve expressar o aproveitamento dos bens para o alcance de interesses existenciais, econômicos e sociais merecedores de tutela" ${ }^{374}$.

Para Ana Rita Vieira Albuquerque "a função social da posse não constitui uma nova figura dogmática do direito privado, mas tem a sua importância ditada como forma de se

\footnotetext{
372 Fábio Konder Comparto. A questão agrária. Direitos e deveres fundamentais em matéria de propriedade.

${ }^{373}$ Ana Rita Vieira Albuquerque. Da Função Social da Posse e sua conseqüência frente à situação proprietária, p. XV.

${ }^{374}$ Orlando Gomes. Direitos Reais (atualização Luis Edson Fachin), p. 41-42.
} 
reinterpretar o direito de posse, que deve passar a ser contemplado sob sua feição social, sob a importância da sua utilidade social (...) ${ }^{375}$, mencionado também os princípios indicados pelo professor Godoy consistentes no interesse da coletividade e no solidarismo.

Para Marco Aurélio Bezerra de Melo, “uma outra concepção nos parece mais consentânea com a realidade brasileira e com a relevante função social que o fenômeno possessório ostenta. Se observarmos com atenção, é na função social da posse que a propriedade é vivificada. Com efeito, talvez seja mais inteligente resgatar apenas a ideia de causa do negócio jurídico para intuirmos sobre o alcance do justo título, ou seja, se o possuidor conseguir demonstrar por qualquer meio legítimo uma relação jurídica que dê suporte a sua posse, como por exemplo uma dação em pagamento em decorrência de serviços prestados ou uma permuta realizada sem os rigores formais exigidos, estaremos diante de um justo título e, portanto, a boa-fé estaria presumida" ${ }^{\text {376. }}$.

Assim, a "funcionalização social do instituto da posse é ditada pela necessidade social, pela necessidade da terra para trabalho, para a moradia, enfim, necessidades básicas que pressupõem o valor de dignidade do ser humano, o conceito de cidadania, o direito de proteção à personalidade e à própria vida. $\mathrm{O}$ direito de posse, pela sua utilidade social, representa antes de tudo, o direito à igualdade, uma necessidade da natureza humana não só de liberdade, mas também de o indivíduo obter a terra pelo próprio trabalho, aproveitando os recursos dela e ainda tirando-lhe os frutos para si e para a sociedade. E, dessa forma, reduz a desigualdade social e incrementa a justiça distributiva"377.

São valores sociais subjacentes à função social da posse: o valor correspondente à vida, à saúde, à moradia, à igualdade, à justiça, e o princípio da dignidade da pessoa humana.

Nesse mesmo sentido, Farias e Rosenvald sustentam que a função social da posse tem uma abordagem diferenciada da função social da propriedade, exatamente porque com ela

\footnotetext{
375 Ana Rita Vieira Albuquerque. Da Função Social da Posse e sua conseqüência frente à situação proprietária, p. 11.

${ }_{376}^{376}$ Marco Aurélio Bezerra de Melo. Direito das Coisas, p. 44.

377 Ana Rita Vieira Albuquerque. Da Função Social da Posse e sua conseqüência frente à situação proprietária, p. 15.
} 
busca se estimular o direito à moradia como direito fundamental de índole existencial, coerente com o princípio da dignidade da pessoa humana ${ }^{378}$.

Desta forma, apercebe-se que há plena independência da função social da posse frente à função social da propriedade, indicando Ana Rita Vieira Albuquerque que a própria Constituição Federal prevê a hipótese de outros princípios não expressamente previstos, conforme dicção do artigo $5^{\circ} \S 2^{\circ}{ }^{379}$, sendo um princípio dedutivo do sistema e não uma lacuna. E lança o alerta "o instituto da posse, sem o correspondente princípio da função social da posse, representa violação ao princípio da igualdade, colocando em risco a unidade, a completitude e a coerência do ordenamento jurídico".

Indica o ministro do Supremo Tribunal Federal Teori Albino Zavascki que a posse não recebeu uma menção expressa como a propriedade (art. $5^{\circ}$, XXII, "garantindo o direito de propriedade"), mas que isso tampouco seria necessário, pois está ela compreendida e entendida de modo indireto, na esfera constitucional: "a disciplina da posse, e a correspondente tutela jurídica, se dá implícita e indiretamente, na medida e em consideração àquilo que ela representa como concretização do princípio da função social $(\ldots)^{, 380}$.

Assim, quer se entenda a posse como fato, quer se entenda como direito, em ambas as hipóteses estará presente o princípio da função social da posse: (i) sendo a posse um direito (real ou pessoal), "o princípio da função social é consequência de um processo lógico de integração sistemática", para assegurar unidade e completitude ao ordenamento; e (ii) sendo a posse um fato, "também nesse caso não se pode deixar de reconhecer a função social da posse (...), por uma interpretação extensiva dos direitos da pessoa humana, do princípio da dignidade da pessoa humana e demais princípios estruturantes do Estado Democrático de Direito" ${ }^{381}$.

\footnotetext{
${ }^{378}$ Cristiano Chaves de Farias; Nelson Rosenvald. Direitos reais, p. 42.

379 "Os direitos e garantias expressos nesta Constituição não excluem outros decorrentes do regime e dos princípios por ela adotados (...)".

${ }^{380}$ Teori Albino Zavascki. A tutela da posse na Constituição e no Novo Código Civil. Revista Brasileira da Direito Constitucional, p. 55.

381 Ana Rita Vieira Albuquerque. Da Função Social da Posse e sua conseqüência frente à situação proprietária, p. 37.
} 
Afirma Castan Tobeñas que hoje está completamente desacreditada a concepção da propriedade como um direito ilimitado sobre a coisa. Seria muito inexato e perigoso ficar nos seguintes extremos: (a) entender a propriedade com um direito absoluto; ou (b) conceituá-la como uma mera função social. Por isso, o meio termo tem sido valorizado na doutrina espanhola, que vem considerando a propriedade privada um direito subjetivo ao ser ligada a uma função social, ou ainda, a um direito subjetivo estabelecido fundamentalmente para proteger o interesse particular do proprietário, satisfazendo o interesse público, uma vez que está subordinada à realização do bem comum.

A nova visão da função social faz penetrar o elemento social na propriedade individual, com um caráter negativo (impor limites à sua extensão e ao seu exercício), mas também em caráter positivo (impor ao proprietário obrigações e responsabilidades relativas ao interesse geral).

Assim, resume Castan Tobeñas, "definitivamente, a propriedade em sua concepção individualista era simplesmente um direito do titular, passando a ter uma concepção social ou solidarista, como um direito que traz consigo obrigações e há que ser exercido não só para a satisfação do proprietário, mas para a utilidade da coletividade" ${ }^{382}$.

Explica Marcos Alcino de Azevedo Torres a função social como a necessidade de desenvolver uma conduta que atenda ao mesmo tempo à destinação econômica e à destinação social do bem ${ }^{383}$. Assim, defende que também são aplicáveis à função social da posse os preceitos da função social da propriedade, pois é com o efetivo cumprimento da função social da posse "que a propriedade logra atender à sua função social e escapar das consequências do não cumprimento”.

Sobre o descumprimento da função social indicam Gustavo Tepedino e Anderson Schereiber: "decorre que se uma determinada propriedade não cumpre a sua função social, perde o seu título justificativo. De fato, se a função social é a noção que surge exatamente na busca de uma legitimidade da propriedade privada, não seria excessivo afirmar que, em

\footnotetext{
${ }^{382}$ Jose Castan Tobeñas. Derecho Civil Español, Comun y Foral, p. 148-150.

${ }^{383}$ Marcos Alcino de Azevedo Torres. A propriedade e a posse. Um confronto em torno da Função Social, p. 308.
} 
sua ausência, seja retirada a tutela jurídica dominical (sic) em situações concretas de litígio, para privilegiar a utilização do bem que, mesmo desprovida do título de propriedade, condiciona-se e atende ao interesse social" ${ }^{384}$.

Nesse caso, um efeito seria que a posse que atende à sua função social deve ser resguardada e privilegiada em relação a outras, "pois não há dúvida de que no confronto entre a posse simples, posse inerte e a posse com função social, deva esta última prevalecer. A posse assim exercida deve ter uma proteção especial do sistema, no confronto com eventuais direitos que se alega ter sobre a coisa e, tal proteção, deve perdurar se e enquanto a posse for exercida com função social" 385 .

Para o professor Rui Geraldo Camargo Viana, "a função social não é um limite da propriedade, na verdade ela é o conteúdo do direito de propriedade, não há propriedade que não cumpra função social. A ação do proprietário que não cumpra a função social pode ser tida como um ato ilícito por abuso de direito" 386 .

Destaca ainda o solidarismo Marcos Alcino de Azevedo Torres ao lembrar que "o Direito Civil, ainda que renovado no trato da posse e da propriedade, não aboliu totalmente as vestes que inspiraram o sistema anterior e privilegiou o ter, enquanto a Constituição Federal privilegiou o ser, coerente com o fenômeno de despatrimonializacão do direito civil" 387 .

Para Luiz Edson Fachin, "a função social da posse situa-se em plano distinto [da função social da propriedade], pois, preliminarmente, a função social é mais evidente na posse e muito menos evidente na propriedade, que mesmo sem uso, pode se manter como tal. A função social da propriedade corresponde a limitações fixadas no interesse público e tem por finalidade instituir um conceito dinâmico de propriedade em substituição ao conceito

\footnotetext{
${ }^{384}$ Gustavo Tepedino, Anderson Schereiber. Questões Agrárias. Julgados comentados e pareceres, p. 120 e s.

${ }^{385}$ Marcos Alcino de Azevedo Torres. A propriedade e a posse. Um confronto em torno da Função Social, p. 376.

${ }^{386}$ Rui Geraldo Camargo Viana. A função social da propriedade. Ministério Publico do Estado do Pará Centro de Apoio Operacional Constitucional..

${ }^{387}$ Marcos Alcino de Azevedo Torres. A propriedade e a posse. Um confronto em torno da Função Social, p. 377.
} 
estático, representando uma proteção da reação anti-individualista”. Assim para este autor, “o fundamento da função da propriedade é eliminar da propriedade privada o que há de eliminável. O fundamento da função social da posse rebela o imprescindível, uma expressão natural da necessidade" ${ }^{388}$.

Para Fachin, a posse tem um sentido especial e peculiar, "o de ser uma forma atributiva da utilização das coisas ligadas às necessidades comuns de todo os seres humanos, e dar-lhe autonomia significa constituir um contraponto humano (...) a uma propriedade concentrada e despersonalizada (...). A posse assume então uma perspectiva que não se reduz a mero efeito, nem a ser encarnação da riqueza e muito menos manifestação de poder: é uma concessão à necessidade. (...). É nesse passo que a posse consiste hoje ao menos numa espécie de legitimação do uso, reservando-se ao futuro do instituto (...) papel de indisfarçável destaque social e histórico"389.

Também o Enunciado 303 da IV Jornada de Direito Civil do Conselho da Justiça Federal: “Art. 1.201. Considera-se justo título para presunção relativa da boa-fé do possuidor o justo motivo que lhe autoriza a aquisição derivada da posse, esteja ou não materializado em instrumento público ou particular. Compreensão na perspectiva da função social da posse".

Por fim, na lição sempre valiosa de Miguel Reale, o Código Civil de 2002, ao mesmo tempo que assegura os valores sociais, preserva, de maneira muito clara e muito nítida, os direitos legítimos dos proprietários: "o individualismo desapareceu, mas o coletivismo absorvente, maciço e massificador, também deve ser evitado, para que a pessoa humana não de dissolva no anonimato coletivo" ${ }^{, 390}$.

Nesse sentido, entendemos ser necessário contextualizar que o legislador constituinte buscou incluir na Constituição Federal todas as muitas demandas sociais existentes no Brasil, conferindo, por um lado, garantia aos direitos individuais da livre iniciativa e da

\footnotetext{
${ }^{388}$ Luiz Edson Fachin. A função social da posse e a propriedade contemporânea (uma perspectiva da usucapião imobiliária rural), p. 19-20.

389 Ibid., p. 21.

${ }^{390}$ Miguel Reale. Anteprojeto do Código Civil, Revista de Informação Legislativa, p. 18.
} 
propriedade. E de outro, resguardando a função social que deve estar presente e ser observada, de forma a mitigar o problema social das desigualdades históricas brasileiras.

Diante disso, não acreditamos que seja possível leitura de ruptura com as premissas constitucionais consideradas individualistas, mas, por outro lado, entendemos que passa a ser expressa a crescente interpretação e visão sociais como superior às atitudes individuais, o que explica o fortalecimento de conceitos como "posse-trabalho" e "posse-moradia".

A Lei $n^{\circ} 11.977$, tal como alterada pela Lei $n^{0} 12.424$, de 2011, corrobora, portanto, com a necessidade de apresentar resposta aos anseios sociais de concretizar a justiça, no sentido de instituir a usucapião administrada, aspecto bastante positivo para a inserção de milhares de pessoas que antes permaneciam à margem da sociedade formal, indicando também a insuficiência do Poder Judiciário, que não se mostra capaz de atender com a rapidez necessária a esta demanda social. Assim, percebemos um fenômeno que continuamente retira da alçada do Poder Judiciário procedimentos que antes eram judiciais, justamente para que direitos fossem reconhecidos, implementados, ou resguardados com mais celeridade. 


\section{POSSE E DIREITO AGRÁRIO}

No Direito romano, o conceito de imóvel era fixado pela sua destinação, sendo o prédio rústico definido como a "propriedade imobiliária situada no campo, ou mesmo na cidade, que se destine à agricultura ou exploração agrícola de qualquer natureza. Já era o sentido que os romanos tinham o praedium rusticum: aquele que se destina à cultura. É o ager. Nesta razão, o prédio rústico caracteriza-se pela natureza do seu uso ou utilização, não importando o local em que se encontra. É rústico quando se destina à plantação ou qualquer espécie de exploração agrícola" ${ }^{391}$.

Olavo Acyr de Lima Rocha ressalta que, apesar de o Brasil não ter produzido ainda um Código Agrário (tal como nas províncias argentinas, México e Uruguai), em 30 de novembro de 1964 passou a contar com uma lei agrária, a Lei n ${ }^{0}$ 4.504, também conhecida como Estatuto da Terra. A grande importância do Estatuto da Terra foi buscar certo nivelamento para a estrutura fundiária brasileira, polarizada entre o latifúndio improdutivo de um lado e o minifúndio antieconômico de outro, buscando também estabelecer as diretrizes da reforma agrária e da modernização da política agrícola do país, notadamente em vista das profundas modificações provocadas pela industrialização e concentração urbana $^{392}$. O artigo $4^{\circ}$ do Estatuto da Terra indica que imóvel rural é o prédio rústico, de área contínua, qualquer que seja sua localização, que se destina à exploração extrativa, agrícola, pecuária ou agroindustrial (...), continuando Cysneiros que com relação aos imóveis rurais existe "um conjunto de conceitos que se interpenetram, dando corpo ao sistema, que se incorpora ao ordenamento jurídico como direito autônomo. Segue-se daí que o fator continuidade da área liga-se ao fator destinação, como também expressa sua necessidade na caracterização, posto que é módulo unidade de medida, de mensuração e dimensão econômica do imóvel" ${ }^{393}$.

Conceitua Fernando Scaff como estabelecimento agrário uma "centralidade que nele geralmente possuem o fundo rústico e os animais, dentre os fatores congregados nessa

\footnotetext{
${ }^{391}$ Vicente Cavalcanti Cysneiros. O estrangeiro e a propriedade rural, p. 42.

${ }^{392}$ Olavo Acyr de Lima Rocha. A desapropriação no direito agrário, p. 45-47.

${ }^{393}$ Vicente Cavalcanti Cysneiros. O estrangeiro e a propriedade rural, p. 42.
} 
particular espécie de unidade funcional" ${ }^{\text {394 }}$. Além do fundo rústico, os vegetais cultivados e animais criados são bens imprescindíveis para a configuração da empresa agrária; sem eles, o estabelecimento agrário não existiria, depreendendo-se daí que a posse agrária também necessitaria de tais elementos para sua configuração. Para José Fernando Lutz, “disso resulta no direito moderno, um novo conceito de propriedade agrária, no que pertine a exploração econômica do espaço rural, assim como o direito brasileiro (...)"395.

Para as professoras Giselda e Silmara, "o imóvel rural é um dos valores máximos na apreciação das relações jurídicas que envolvam a propriedade, dado que é esse valor que configura a forma e o conteúdo à denominada posse agrária e que atua, de modo relevante, na conjugação dos fatores de produção econômica" ${ }^{396}$.

Fernando Campos Scaff indica que fundo rústico é definido como sendo primordialmente (embora não somente) a terra trabalhada ou destinada à produção, normalmente vinculada à agricultura e pecuária, como originadora dos produtos rurais, sendo "o fundo rústico veio a caracterizar, de maneira fundamental, a estrutura e classificação das propriedades rurais, conforme estabelecido pelo Estatuto da Terra ${ }^{397 ", ~}$. Em obra mais recente, que contou para obtenção de título de livre-docente, acrescenta Scaff que, apesar de mais modernamente a doutrina deixar de atribuir caráter imprescindível à presença do fundo rústico à atividade agrária, "sua importância, dentre os bens que compõem essa universalidade, não deva ser desconsiderada" 398 .

Por atividade agrária podemos entender o "elemento constitutivo essencial do conceito de direito agrário. Tal atividade compreende uma série de atos dirigidos à produção econômica da terra, que são executados pelo homem do campo, com fito de lucro, num processo agrobiológico no qual sua participação se faz de maneira ativa, em estreita colaboração com a própria natureza" ${ }^{399}$.

\footnotetext{
${ }^{394}$ Fernando Campos Scaff. Teoria Geral do Estabelecimento Agrário, p. 104-105.

395 José Fernando Lutz Coelho. Contratos Agrários. Uma visão neo-agrarista, p. 44.

${ }^{396}$ Giselda Maria Fernandes Novaes Hironaka, Silmara Juny de Abreu Chinelato. Revista da Faculdade de Direito da Universidade de São Paulo, Propriedade e Posse: uma releitura dos ancestrais institutos, p. 82.

${ }^{397}$ Fernando Campos Scaff. Aspectos Fundamentais da Empresa Agrária, p. 114-115.

${ }^{398}$ Idem. Direito Agrário. Origens, Evolução e Biotecnologia, p. 35.

${ }^{399}$ Giselda Maria Fernandes Novaes Hironaka. O extrativismo no direito agrário brasileiro, p. 131.
} 


\subsection{POSSE AGRÁRIA}

Ensinam as autoras e professoras Giselda Maria Fernandes Novaes Hironaka e Silmara Juny de Abreu Chinelato ${ }^{400}$ que a posse agrária, tal como qualquer outra posse, também é formatada a partir do animus e do corpus, indicando que se externalizam de forma distinta: o corpus "é configurado por atos materiais que expressam a vinculação direta e imediata do possuidor à terra, por meio da organização dos fatores de produção, para o desenvolvimento da adequada e racional empresa agrária. Já o elemento animus, fator subjetivo, revela-se como a intenção do possuidor de exercer a atividade agrária para, daí, extrair riquezas". Assim, o exercício da posse agrária envolve "todo um elenco de atos que o possuidor agrário realiza com vistas à exploração econômica do bem, todos eles sujeitos aos riscos correlatos da natureza e suas soberanas forças, mas que, afinal, se desencadeiam em harmonia perfeita e singular, realizando o ciclo biológico do produto almejado" ${ }^{401}$; desta forma, haveria nesse rurícula mais que um singelo animus, mas "uma árdua e cotidiana realização do homem sobre a terra, na expectativa de exaltar-lhe o atributo de bem de produção, quando a provoca para o cumprimento de sua finalidade máxima, que é a função social da propriedade imobiliária rural".

Como definição para posse agrária, apresenta Getúlio Targino Lima o seguinte: "é o exercício direto, contínuo, racional e pacífico, pelo possuidor, de atividade agrária desempenhada sobre um imóvel rural, apto ao desfrute econômico, gerando a seu favor um direito de natureza real especial, de variadas consequências jurídicas e visando ao atendimento de suas necessidades socioeconômicas, bem como as da sociedade" ${ }^{\text {402 }}$.

Para as professoras acima indicadas, há ainda mais um qualificar que distingue a posse agrária, além do acima indicado animus expandido: o conceito de morada habitual, aspecto característico do Direito brasileiro, originado no perídio histórico do regime de posses: a morada habitual é o "locus agrário onde o empreendedor levará a efeito a sua atividade agrária, o seu trabalho produtivo. E são estes então - trabalho produtivo e morada habitual

\footnotetext{
${ }^{400}$ Giselda Maria Fernandes Novaes Hironaka, Silmara Juny de Abreu Chinelato. Revista da Faculdade de Direito da Universidade de São Paulo, Propriedade e Posse: uma releitura dos ancestrais institutos, p. 83. ${ }^{401}$ Giselda Maria Fernandes Novaes Hironaka, Silmara Juny de Abreu Chinelato. Revista da Faculdade de Direito da Universidade de São Paulo, Propriedade e Posse: uma releitura dos ancestrais institutos, p. 84. ${ }^{402}$ Getúlio Targino Lima. A posse agrária sobre bem imóvel, p. 92.
} 
- os requisitos da distinta e qualificada posse agrária, que difere da posse comum pelo fato da produtividade e da pessoalidade do ato agrário, contagiando-se e impregnando-se da milenar função social da propriedade (...)". E concluem as autoras que "é exatamente essa posse - assim qualificada pelos atributos que a integram - a posse hábil à aquisição da propriedade pela via da usucapião. Vale dizer: é, a posse agrária, a posse ad usucapionem capaz de gerar o usucapião especial" ${ }^{\prime 403}$.

Para Antonio Augusto de Souza Coelho, o que "distingue a posse agrária da posse dita civil, é a peculiaridade de seu corpus, vale dizer, por ser exercida atividade agrária sobre imóvel rural, com observância à função social. É o corpus da posse agrária, ou seja, o elemento material da posse agrária é a visibilidade da propriedade agrária, o aspecto exterior dela". Assim, não seria possível confundir a propriedade agrária com a propriedade do Direito Civil, pois para haver posse agrária deve estar presente (a) o exercício de atividade agrária; e (b) a observância da função social. Caso o proprietário não cumpra a função social, haverá posse "civil", mas não "agrária", de forma que a posse agrária corresponde à visibilidade da propriedade agrária ${ }^{404}$. O corpus surge com o exercício da atividade agrária, com observância da função social, e o animus com a intenção de ser proprietário agrário. Ressalta, todavia, que essa distinção entre posse agrária e posse civil não resulta em importância prática na tutela das ações possessórias.

Nesse sentido, no entender de Antonio José de Mattos Neto ${ }^{405}$, o artigo 191 da Constituição Federal, ao tratar da usucapião agrária especial, incluiu como exigência (além dos requisitos comuns a toda e qualquer posse), (a) a produtividade da terra por trabalho pessoal do trabalhador e de sua família e (b) a moradia no local. Assim, tais seriam os dois elementos que caracterizam a posse agrária ${ }^{406}$.

\footnotetext{
403 Giselda Maria Fernandes Novaes Hironaka, Silmara Juny de Abreu Chinelato. Revista da Faculdade de Direito da Universidade de São Paulo, Propriedade e Posse: uma releitura dos ancestrais institutos, p. 85. ${ }^{404}$ Antonio Augusto de Souza Coelho. A Proteção possessória do imóvel rural e a posse agrária, Jus Navigandi, ano 16, n. 2924.

405 Antonio Jose de Mattos Neto. Institutos básicos do direito agrário à luz da Constituição de 1988. Revista de Direito Civil Imobiliário, Agrário e Empresarial, n. 55, janeiro/março de 1991, v. 15, p. 136.

${ }^{406}$ Ainda no que se refere ao regime de exploração das terras, no tocante à atividade extrativa do látex, indica a professora Giselda Maria Fernandes Novaes Hironaka que predominam "os grandes estabelecimentos, típicos latifúndios por dimensão, vez que as árvores, distantes entre si, encontram-se espalhadas por áreas de centenas de hectares, via de regra, terras devolutas, arrendadas por tempo indeterminado. O seringalista, em pouquíssimos casos, é o proprietário do seringal; quase sempre é arrendatário do Estado, ou enfiteuta, ou usufrutuário ou posseiro. (...) Evidentemente, o regime mais comum de exploração da terra é o
} 
Para Getúlio Targino Lima, a posse agrária "não se dá apenas sobre o imóvel rural, mas sobre todo o conjunto dos bens agrários que integram a exploração rural a que se dedique o possuidor" ${ }^{407}$.

Ensina Wellington Pacheco Barros que "além de ser um direito individual ela [a propriedade] também deve produzir. E assim, a proteção que deve merecer aquele [direito proprietário] decorre da satisfação desta [finalidade social]. O direito do proprietário à proteção constitucional, logo, está vinculado à anterioridade de satisfazer a sua finalidade social" ${ }^{\prime 408}$.

Ainda para Antonio José de Mattos Neto ${ }^{409}$, a posse, sob o ângulo do Direito Agrário, apresenta algumas características particulares: "só se admite o exercício direto e pessoal da posse; que nela seja desenvolvida atividade agrária (extrativismo, agricultura, pecuária ou agroindústria), não sendo possível a acessio possessionis nem a sucessio inter vivos; exigese morada habitual e cultura efetiva no trecho de terra ocupada, bem como sempre independe de justo título e boa-fé, para haver a consolidação do jus possessionis agrário necessário e suficiente para gerar efeitos”. Assim, em resumo, para referido autor, a posse seria vista como a posse-trabalho: o trabalho terá esse valor jurídico de forma que, após o transcurso do lapso de tempo indicado por lei, haverá a recompensa ao trabalhador: o direito ao domínio do bem trabalhado.

\subsection{FUNÇÃO SOCIAL APLICADA À POSSE AGRÁRIA}

A previsão da função social relativa ao imóvel rural está contida no artigo 184 da Constituição Federal, ao estabelecer que, caso o imóvel não atenda ao interesse público ou

arrendamento". O extrativismo como atividade agrária. Jus Navigandi, disponível em: $<$ http://jus.com.br/artigos/1667>. Acesso em: 14 de dezembro de 2013.

${ }^{407}$ Getulio Targino Lima. Direito Agrário: novo enfoque de sua relação fundamental (homem, terra, produção) e releitura de alguns de seus princípios, Revista de Direito - Procuradoria-Geral do Estado de Goiás, p. 75.

${ }^{408}$ Wellington Pacheco Barros. A propriedade agrária e seu novo conceito jurídico-constitucional, Revista da Ajuris, n. 46 - julho 1989, p. 144.

${ }^{409}$ Antonio Jose de Mattos Neto. A Jurisprudência de posse no direito agrário brasileiro - perspectivas críticas. Revista de Direito Civil Imobiliário, Agrário e Empresarial, n. 10, janeiro/março de 1986, v. 10, p. 177. 
aos requisitos da função social estabelecidos no artigo 186, poderá sofrer a penalização de expropriação para fins de reforma agrária. Nesse sentido, determina o citado art. 186:

Art. 186. A função social é cumprida quando a propriedade rural atende, simultaneamente, segundo critério e graus de exigência estabelecidos em lei, aos seguintes requisitos:

I - aproveitamento racional e adequado;

II - utilização adequada dos recursos naturais disponíveis e preservação do meio ambiente;

III - observância das disposições que regulam as relações de trabalho;

IV - exploração que favoreça o bem-estar dos proprietários e trabalhadores.

Lima Rocha dispõe ter sido o Estatuto da Terra o primeiro texto legal ordinário a dar funcionalidade ao princípio da função social da propriedade (anteriormente inserido na Constituição de 1934 e ampliado no diploma de 1946 e na Emenda Constitucional n ${ }^{\circ}$ 10/64). Isto porque já previa em, seu artigo $2^{\circ}$, ser assegurada a todos a oportunidade de acesso à propriedade da terra, condicionada pela sua função social, explicando em seu $\S 1^{\circ}$ que a "propriedade da terra desempenha integralmente a sua função social quando, simultaneamente: (a) favorece o bem-estar dos proprietários e dos trabalhadores que nela labutam, assim como de suas famílias; (b) mantém níveis satisfatórios de produtividade; (c) assegura a conservação dos recursos naturais; (d) observa as disposições legais que regulam as justas relações de trabalho entre os que a possuem e a cultivem”. Esse mesmo artigo, com pequena alteração que não afeta o sentido, foi reproduzido no artigo 186 da Constituição Federal de 1988. A alteração, também destacada por Lima Rocha, consistiu na substituição da alínea "b" (manutenção de níveis satisfatórios de produtividade), por texto que reflete o aproveitamento racional e adequado do solo ${ }^{410}$.

Lembram Noronha, Boni e Bratz que, no tocante ao imóvel rural, a necessidade de “cumprir com o fim social não significa uma limitação ao uso da propriedade, mas sim determina a necessidade de intensificação desse uso, para que o máximo de 
aproveitamento seja alcançado",411, pois, caso a propriedade rural não atinja essa potencialidade produtiva determinada pelo INCRA - Instituto Nacional de Colonização e Reforma Agrária, ficará elegível à desapropriação para reforma agrária. Assim, para os referidos autores, o imóvel rural atende à função social quando "seus níveis de produção são satisfatórios, aqueles que nela trabalham vivem em condições dignas de subsistência; as relações trabalhistas são observadas; há preservação dos recursos naturais". Desta forma, o fundamento da função social da posse do imóvel rural reflete "uma expressão natural da necessidade de utilização da terra, para que a natureza seja transformada em proveito de todos. O direito à posse representa a possibilidade do indivíduo obter a terra pelo trabalho, aproveitando seus recursos e dela tirando o seu sustento" ${ }^{412}$.

Destaca ainda Fernando Scaff que a propriedade imobiliária rural apresenta certas características que a tornam, sob determinado ângulo, diferente daquela situada em zonas urbanas, notadamente pela necessidade de atendimento ao desenvolvimento sustentável. E conclui: "a despeito de a propriedade imobiliária rural ou agrária constituir espécie de um gênero de instituto jurídico e não um outro gênero - estando nela presente, em regra, as mesmas facilidades de usar, fruir, dispor ou de reaver o bem daquele que injustamente o detenha -, há de se reconhecer que a intensidade e o modo de exercício dessas mesmas facilidades recebem temperamentos específicos, vinculados justamente ao conceito de função social que é aplicável tanto à empresa como, por consequência, aos bens componentes de um estabelecimento agrário" ${ }^{413}$.

Assim, concluem Noronha, Boni e Bratz que a posse do imóvel rural deve ser utilizada em conformidade à consciência social, visando o aproveitamento útil do solo e a diminuição da desigualdade social ${ }^{414}$.

Paulo Guilherme de Almeida ensina que a função social consiste na observância de determinadas condições no exercício do direito de propriedade, no sentido de que este exercício considere os interesses da coletividade, que não podem ser prejudicados pelo

\footnotetext{
411 Durval de Noronha Goyos Jr., Adriano Boni de Souza, Eduardo Bratz. Direito Agrário Brasileiro e o Agronegócio Internacional, p. 162.

412 Ibid., p. 168.

${ }^{413}$ Fernando Campos Scaff. Direito Agrário. Origens, Evolução e Biotecnologia, p. 37-39.

${ }^{414}$ Durval de Noronha Goyos Jr., Adriano Boni de Souza, Eduardo Bratz. Direito Agrário Brasileiro e o Agronegócio Internacional, p. 169.
} 
titular de domínio: "a comunidade deve merecer a proteção do Estado que, ao mesmo tempo, obriga-se a respeitar o direito individual, especificadamente, o de propriedade" 415

Nesse sentido, concorda o professor Rui Geraldo Camargo Viana: "As constantes alterações na disciplina urbanística vêm modificar o conteúdo do direito de propriedade, cada vez mais restrito, no exercício de suas faculdades, cedendo o interesse particular ou individual aos reclamos de consciência e bem estar da maioria. (...) que dão à propriedade uma nova roupagem, superando o modelo ideologicamente baseado no individualismocapitalista". Continua referido mestre que "a tônica atual desse direito é a sua limitação imposta em benefício da coletividade, ou seja, o conteúdo da propriedade torna-se mutável, ao influxo das necessidades e conveniências sociais, pelo que sua feição é moldada sem peias pelo legislador" 416 .

A função social se destaca ainda mais quando se trata de propriedade rural, "isto porque todo relacionamento da atividade agropecuária e que repercute na esfera jurídico-agrária, tem origem, em última análise, no uso da terra, constituindo esta bem condicionado à função social, por excelência" ${ }^{417}$. Desta forma, lembra Paulo Guilherme de Almeida que a unanimidade dos agraristas recomenda que o condicionamento da propriedade imobiliária rural à sua função social seja adotado pelas diversas legislações. Salienta o autor, ainda, que toda a estratégia de política agrícola está fundada nos princípios que condicionam a propriedade à sua função social, abrange especialmente (a) o aspecto de ordem social, correspondendo à valorização do homem do campo; e também (b) o aspecto de ordem econômica, buscando a produção ${ }^{418}$. As restrições à propriedade são justificadas pelas necessidades coletivas, devendo-se colocar o interesse público acima do particular.

Acrescentam as professoras Giselda e Silmara, sobre a função social da posse: "sabe-se que é a posse quem vivifica e confere efetividade ao ancestral direito real, nada mais

\footnotetext{
${ }^{415}$ Paulo Guilherme de Almeida. Direito Agrário. A propriedade imobiliária rural, p. 17-21.

${ }^{416}$ Rui Geraldo Camargo Viana. A função social da propriedade. Ministério Público do Estado do Pará Centro de Apoio Operacional Constitucional.

${ }^{417}$ Paulo Guilherme de Almeida. Direito Agrário. A propriedade imobiliária rural, p. 24.

${ }^{418}$ Ibid., p. 97.
} 
simples e natural que a conclusão que prestigia a identidade descortinada entre a posse e o princípio da função social da propriedade"419.

Nas palavras de Fernando Pereira Sotero, "o principio básico da função social da propriedade é o grande fundamento da reforma agrária brasileira; e totalmente inspirada em que o fundamento do direito à propriedade é o trabalho: a terra é de quem a trabalha, de quem a faz produzir, de quem a amanha. A simples detenção da terra pelo poderio econômico de seu proprietário ausente, não tem guarida em uma lei de reforma agrária como a brasileira, em um país que necessita de maior e melhor produção (...), com o intuito de evitar que o imóvel fique improdutivo aguardando a valorização fundiária”. Acrescenta ainda o autor a necessidade de se "deixar bem claro que a terra deveria pertencer a quem a trabalha, a quem a fecunda, a quem dela retira seu sustento de forma profissional. Fica certo pois que o trabalho é o elemento que deverá caracterizar e fundamentar o direito de propriedade" ${ }^{, 420}$.

Em conclusão, torna-se recomendável a inclusão de cláusulas contratuais que garantam que o proprietário que cede o uso de suas terras não corra o risco de perdê-las diante do não cumprimento efetivo da função social:

Obrigações e responsabilidades fundiárias. A Agricultora deverá, durante toda a vigência deste Contrato, observados os respectivos prazos de ocupação, exercer em cada uma das áreas atividades suficientes para caracterizá-las como produtivas, nos termos da legislação fundiária em vigor, respeitando os graus de eficiência e de utilização (Graus de Utilização da Terra - GUT e de Eficiência na Exploração GEE) e eventuais outros critérios definidos pelas leis e regulamentos vigentes. A Agricultora deverá também adotar todas e quaisquer providências que se mostrem cabíveis para, se for o caso, demonstrar tal circunstância perante o INCRA elou qualquer outro órgão público competente para esse fim.

\footnotetext{
${ }^{419}$ Giselda Maria Fernandes Novaes Hironaka, Silmara Juny de Abreu Chinelato. Revista da Faculdade de Direito da Universidade de São Paulo, Propriedade e Posse: uma releitura dos ancestrais institutos, p. 81. ${ }^{420}$ Fernando Pereira Sotero. Direito Agrário e Reforma Agrária, p. 89-91.
} 


\section{AQUISIÇÃO DA POSSE}

Para Savigy, independentemente de qualquer outro fator, a ausência do animus torna impossível a aquisição da posse. Aquele que não pode ter a vontade, não pode adquirir a $\operatorname{posse}^{421}$.

Perozzi $^{422}$ afirmava que a "tomada de posse" é o único modo de aquisição da posse. Esta tomada de posse está ligada à posse em uma relação de causa e efeito. A tomada de posse tem natureza de fato como posse, e é a realização da vontade de ter liberdade com relação à coisa, realização feita sem a intervenção do Estado.

No que se refere à aquisição da posse, no ensinamento de Lafayette ${ }^{423}$, como a posse não apresenta um direito anterior que a fundamente ou uma manifestação expressa, ela é iniciada pelo simples poder físico de dispor da coisa, com a intenção de havê-la como própria; uma vez presentes tais elementos, já se perfaz a produção dos efeitos legais correspondentes.

Para Coelho da Rocha, o início da posse ocorre com a apreensão, ou tomada da posse, sendo "um fato material qualquer patente, pelo qual o adquirente se entende ficar legitimamente habilitado para dispor da coisa" ${ }^{424}$.

Para estar configurada a aquisição da posse, deve haver relação com a coisa (apreensão material da coisa móvel ou ingresso na coisa imóvel com a intenção de tê-la como própria). A posse pode ser adquirida por meio de terceiro ${ }^{425}$.

No Direito justianeo, surge o fenômeno da espiritualização da posse, significando que, para que a posse desapareça, não basta a perda da possessio corpore, "deve desaparecer também o animus possidendi, espontânea ou coercitivamente" ${ }^{\text {426. }}$.

\footnotetext{
${ }^{421}$ Frédéric Charles de Savigny. Traité de la possession en droit romain, p. 222.

${ }^{422}$ Silvio Perozzi. Istituzioni di Diritto Romano, p. 830.

${ }^{423}$ Lafayette Rodrigues Pereira. Direito das Coisas, p. 26.

${ }^{424}$ M. A. Coelho da Rocha. Instituições de Direito Civil - tomo II, p. 258.

${ }^{425}$ Ebert Chamoun. Instituições de Direito Romano, p. 222.

${ }^{426}$ Ibid., p. 224.
} 
A aquisição da posse deve originar-se de um ato de vontade ou, ainda, da lei. Sendo a pessoa natural ou jurídica sujeitos de direito, podem elas, por ato de vontade, possuir algo (bem como tornarem-se proprietárias de algo). Assim, a aquisição da posse "é ato de ciência ou consciência do sujeito criador do estado de aparência que (...) surge aos olhos da sociedade como relação de posse" ${ }^{427}$.

Venosa alega que o antigo Código de 1916 desnecessariamente regulou as formas de aquisição da posse no artigo 493, pois incorporou a teoria objetiva da posse de Ihering, posse esta que resultaria "apenas da circunstância de ser fixada uma exteriorização da propriedade. (...) Toda vez que se evidenciar essa situação de fato, existirá posse”. Isso mudou com o artigo 1.204 do Código Civil de 2002, que apresenta fórmula geral e genérica: "adquire-se a posse desde o momento em que se torna possível o exercício, em nome próprio, de qualquer dos poderes inerentes à propriedade". Trata-se da posse adquirida de modo originário, que ocorre sem qualquer vinculação com o possuidor anterior, por ato unilateral de apropriação ou ocupação da coisa, mediante um exercício de poder de fato sobre a coisa ${ }^{428}$.

Ocorrerá a posse adquirida de modo derivado quando houver transferência de uma pessoa para outra, mediante ato ou negócio jurídico bilateral (decorrente da vontade das partes, da tradição, da entrega, ou da deslocação). A posse será derivada da lei quando ocasionada por morte ou ainda com relação aos frutos que caem da árvore do vizinho na terra de outro.

Em princípio, posse originária é aquela adquirida sem vícios; porém, se derivada, se houver vício, este será transmitido com a posse, uma vez que as mesmas características existentes permanecerão, por força do artigo 1.203 do Código Civil de 2002.

\footnotetext{
${ }^{427}$ Silvio de Salvo Venosa. Direitos Reais, p. 79.

${ }^{428}$ Ibid., p. 81.
} 


\section{LEGISLAÇÃO ESTRANGEIRA}

\subsection{PORTUGAL}

Ruy Barbosa ensina que Portugal e também Itália seguiram a teoria subjetiva em suas codificações civis, apesar "dos notórios inconvenientes de sua construção, designadamente a dificuldade da prova do elemento volitivo"429.

Para o grande doutrinador português Vieira, "a posse é um produto histórico do Direito Romano, (...) para descrever a situação de alguém que tem o poder de fato sobre uma coisa (...), independentemente da existência de título de aquisição. Para os romanos sempre foi claro que a posse é distinta da propriedade" "430; como também indicado pelo autor: "A posse é concebida como imagem exterior da propriedade, sem se confundir, no entanto, com ela".

Nos ensinamentos de Bonfante, conforme elencado por Vieira ${ }^{431}$, em Roma encontravamse ao menos três formas de vislumbrar a situação de possessão:

(a) possessio naturalis. Seria a detenção e não a verdadeira posse. "O detentor também tem o elemento de fato que está na base da posse, no entanto, e segundo a maioria dos romanistas, não tem a intenção de exercer um direito próprio, o aninum possidendi, atuando em nome e por conta de outra pessoa, que é a verdadeira possuidora". Todavia, as fontes não são claras se esse termo também foi usado para indicar a posse em si.

(b) possessio. Posse, que no Direito romano "envolve um elemento material, que os romanos denominavam possidere corpore, e que surge posteriormente designado por corpus, numa evolução terminologicamente incorreta, mas que se tornou usual na doutrina, e - pelo menos segundo a grande maioria dos romanistas - um elemento subjetivo, o animus possidendi ou possidentis, possessoris, affectio possidendi, propositum possidendi, animus rem sib habendi, (...)", de forma que "quem tem o corpore possidere sem o animus

\footnotetext{
${ }^{429}$ Ruy Barbosa. Posse de direitos, p. 15.

${ }^{430}$ José Alberto C. Vieira. Direitos Reais, p. 513.

${ }^{431}$ Ibid., p. 515.
} 
possidendi é mero detentor. "A possessio atribui ao possuidor a tutela interdital, uma forma de tutela admitida pelo pretor para defender a posse contra atos turbativos ou de esbulho praticado por terceiros. E por essa razão, de admitir a defesa por interditos, era também designada pelas fontes romanas como possessio ad interdicta", lembra ainda o doutrinador português Vieira $^{432}$.

(c) possessio civilis. Era também conhecida por possessio ad usucapionem. Era a posse requerida por lei para a aquisição da propriedade por usucapião (essa posse facultava a aquisição do dominum depois de transcorrido certo período de tempo. Daí ser considerada verdadeiro direito, ao contrário da possessio). Era considerada uma posse qualificada, porque baseada "em uma posse fundada numa iusta causa, isto é, um fato reconhecido pelo ius civile para transferir a propriedade, independentemente da validade desse fato (a compra e venda viciada, por exemplo, constitui um título justificativo da posse, mesmo que não transfira o direito de propriedade).

Todavia, para Vieira, a opção feita pelo sistema português recaiu sobre a teoria objetiva de Ihering (mas muitos autores em Portugal entendem como sendo, na verdade, a teoria subjetiva): "Reafirmamos, assim, que o Código Civil Português é integralmente objetivista em sede de regulação de posse Havendo corpus possessório e não incidindo nenhuma norma jurídica que descaracterize a situação para mera detenção, (...) existirá posse. $\mathrm{O}$ animus não é, assim, um dos elemento da posse" ${ }^{433}$.

Indica Ascensão que a doutrina portuguesa se inclina à teoria subjetiva, considerando o novo Código Civil português como integrado a esta teoria, o que acaba contestando, em razão de não haver no novo Código referências ao animus. ("A lei é em tudo marcadamente objetivista") e cita Menezes Cordeiro como opinião também contrária à acolhida da teoria subjetiva pelo Código ${ }^{434}$.

Por sua vez, Menezes Cordeiro afirma que encontra subsídios das duas doutrinas nos artigos relativos à posse na codificação portuguesa. "A primeira constatação é a de que o

\footnotetext{
${ }^{432}$ José Alberto C. Vieira. Direitos Reais, p. 516.

${ }^{433}$ Ibid., p. 545.

${ }^{434}$ José de Oliveira Ascensão. Direito das Coisas - reais, p. 86.
} 
Código Civil português, pela ligeireza com que foi revisto, acabaria por consagrar um sistema misto, ou melhor: sobreposto" ${ }^{435}$.

Segundo Ascensão ${ }^{436}$, a posse pode ser classificada nas seguintes modalidades:

(a) Posse titulada e não titulada. "Muito frequentemente a posse tem na sua origem um determinado negócio jurídico, que em abstrato é idôneo para operar a transferência do direito, mesmo que em concreto não o seja, porque inválido. Esse negócio jurídico é o titulo da posse; justo titulo lhe chamava o código de 1867, não porque seja um título válido em concreto (pelo contrário, na posse formal é necessariamente um título inválido) mas porque em abstrato ele seria adequado para a obtenção do efeito de direito substantivo que se pretendia".

(b) Posse de má-fé e posse de boa-fé. A posse titulada se presume de boa-fé, e a não titulada de má-fé.

(c) Posse pacífica e posse violenta. Pacífica seria aquela adquirida sem violência, ocorrendo esta última quando o possuidor usar de coação física ou coação moral para adquiri-la. A posse que começou violenta, sempre manterá esse caráter.

(d) Posse pública e posse oculta. Para a constituição da posse, é necessário haver a prática reiterada, com publicidade, dos atos materiais correspondentes ao exercício do direito. A posse oculta também é posse, mas "é preterida pela melhor posse do possuidor esbulhado".

(e) Posse efetiva e posse civil. A oosse efetiva tem correspondência na situação de fato e pode dar a utilização econômica a coisa e ainda "tem que haver uma aparência que só pode ser dada pela efetividade de posse", uma vez que a posse civil não tem essa correspondência, ou seja, será "meramente civil sempre que não tenha como suporte a situação de fato correspondente", como por exemplo a posse que se mantém após um ano da ocorrência do apossamento por outrem.

\footnotetext{
${ }^{435}$ António Menezes Cordeiro. A Posse: perspectivas dogmáticas actuais, p. 64.

${ }^{436}$ José de Oliveira Ascensão. Direito das Coisas - reais, p. 96-102.
} 
Percebe-se que a maior ausência no sistema de classificação português consiste na dicotomia posse direta e indireta.

Como não chegou a doutrina portuguesa a este conceito, os doutrinadores permaneceram ainda nos dias de hoje a discutir sobre a existência de "uma verdadeira posse desacompanhada da situação de fato" ${ }^{\text {"437 }}$. Por isso, sempre encontram soluções conflitantes, como atesta Ascensão: "daí pois a relevância do corpus (e para outros também do animus). Só não é correto considerar estes 'elementos' da posse. Serão antes pressupostos desta: essenciais numa fase inicial, mas podendo apagar-se na vida da situação jurídica, que goza de relativa autonomia".

\subsection{FRANÇA}

A mais recente doutrina francesa também ressalta a qualidade de fato da posse e a necessidade de sua proteção, como um estado de aparência: "A aparência dos fatos determina sua legitimidade jurídica e acaba por prevalecer sobre esta. Assim, para privilegiar a realidade e preservar a ordem estabelecida e a paz pública, o direito protege as situações de fato, mesmo que ilegítimas, e as transformam em situações jurídicas, mesmo que em detrimento da moral e da justiça" ${ }^{438}$. Continuam referidos autores para reforçar que "Com relação ao direito das coisas, a posse, simples poder material e de fato sobre uma coisa, estabelece ou engendra a propriedade, situação de direito que repousa sobre uma verdadeira vontade jurídica reconhecida legalmente".

É o que também prevê o artigo 2.278 do Código Civil francês:

“Art. 2.278. A posse é protegida, sem levar em consideração o direito subjacente, contra a turbação que a afete ou ameace".

Nesse mesmo sentido, François Terré e Philippe Simler apregoam que a posse: “é uma relação de fato entre uma pessoa e uma coisa, mediante a qual a pessoa tem a possibilidade de beneficiar-se, diretamente ou por intermédio de outra, dos atos que correspondem ao

${ }^{437}$ José de Oliveira Ascensão. Direito das Coisas - reais, p. 105.

${ }^{438}$ Jean-Louis Bergel, Marc Bruschi, Sylvie Cimamonti. Traité de Droit Civil - Les biens, p. 57. 
exercício de um direito, manifestando-os exteriormente, sendo ou não regular titular de tal direito" 439 .

Expressando ser a posse um poder fático, continuam Jean - Louis Bergel, Marc Bruschi, Sylvie Cimamonti que "a posse não consiste mais que um poder de fato, consistente com o exercício material das prerrogativas sobre um bem que está subordinado, sendo ou não seu titular (...) $)^{, 440}$.

Manifestam também François Terré e Philippe Simler que a posse consiste em "um estado de fato que se mostra com semelhanças ao exercício das prerrogativas correspondentes à propriedade (...), a posse é um fato, independentemente da verificação da existência de correspondência ou não com um direito" ${ }^{, 41}$.

Deixando claro que a posse não passa de aparência materializada da propriedade e dos direitos reais, os aludidos autores completam que: "pode-se dizer, de forma geral e simplificada, que a posse não passa da aparência material da propriedade e dos direitos reais, mas que recebe proteção própria, com características próprias: o possuidor pode se defender contra todos os turbadores, e adquirir a propriedade de um bem, mesmo contra o proprietário original" ${ }^{442}$.

Resta, portanto, claro que, para a doutrina francesa, a posse reflete a exteriorização e a visibilidade da propriedade.

François Terré e Philippe Simler definem posse como Possessio rei - la possession des choses corporelle, "é a possibilidade de fruição completa e exclusiva de uma coisa correspondente ao exercício regular do direito de propriedade" ${ }^{443}$.

\footnotetext{
${ }^{439}$ François Terré, Philippe Simler. Droit Civil - Les biens, p. 155.

${ }^{440}$ Jean-Louis Bergel, Marc Bruschi, Sylvie Cimamonti. Traité de Droit Civil - Les biens, p. 58.

${ }^{441}$ François Terré, Philippe Simler. Droit Civil - Les biens, p. 154.

${ }_{442}$ Jean-Louis Bergel, Marc Bruschi, Sylvie Cimamonti. Traité de Droit Civil - Les biens, p. 58.

${ }^{443}$ François Terré, Philippe Simler. Droit Civil - Les biens, p. 153.
} 
Afirmam ainda que o Direito moderno protege, de certa forma, o exercício de fato dos direitos de crédito, de família e dos direitos subjetivos, fazendo a lei francesa expressa menção à posse de direitos, como a posse de direito de crédito.

Afirma Dubertret que a teoria objetiva de Ihering assumiu na França e no seu Direito positivo posição de superioridade. Ademais, em matéria de aquisição da posse, as duas teorias chegam ao mesmo resultado (Ihering exige que o detentor se subordine à relação pessoal que indique uma posse superior; também Savigny ao pregar a importância do animus resulta na exclusão do detentor dos efeitos da posse), mas diferenciam-se quanto à defesa e proteção da posse, pois Ihering defende a proteção a todas as pessoas que tenham a coisa, podendo ser o possuidor ou o detentor, enquanto Savigny outorga a defesa apenas ao possuidor ${ }^{444}$.

A teoria de Ihering consagrou-se na Alemanha e foi apoiada no Direito francês por Saleilles, nas obras Elements constitutifs de la Possession, La possession des meuble e La théorie possessoire ducode civil allemand, e acabou se tornando de forma geral superior à do próprio Código Civil francês, de forma que nas noções de corpus e animus foram evoluindo e adquirindo os contornos próximos dos idealizados por Ihering.

No tocante à definição entre as teorias ocorrida na França, o ensinamento é no sentido de que predominou a teoria subjetiva: "tradicionalmente, foi acatada no sistema Francês a concepção subjetiva. Por muito tempo a concepção francesa caracterizou-se fundamentalmente pela exigência da intenção de agir independente, de forma que a posse por outro não era considerada como uma posse verdadeira" ${ }^{445}$. E denotam referidos autores que a doutrina francesa finalmente acabou por capitular e admitir a superioridade da teoria objetiva alemã ao se assemelhar a ela, como se denota a seguir: “(...) a controvérsia doutrinária não pode mais servir de referência. A divergência entre o subjetivismo francês e o subjetivismo alemão perdeu uma grande parte de sua importância, especialmente depois que no direito francês, a situação do detentor precário melhorou muito em decorrência da jurisprudência e da lei, no tocante à extensão da proteção possessória. Como tais resultados foram alcançados, o modelo alemão que frequentemente era indicado

${ }^{444}$ Matthieu Dubertret. Negociabilité et possession, p. 295.
${ }^{445}$ François Terré, Philippe Simler. Droit Civil - Les biens, p. 158. 
como modelo a ser seguido por décadas, deixou completamente de ser considerado melhor que o francês".

Ensina ainda Catherine Krief-Semitko que a doutrina francesa aceita tanto a posse de bens como a posse de direitos: "Conforme o disposto no artigo 2.255 (art. 2.228 no direito anterior), do Código Civil, a posse pode ter como objeto tanto uma coisa como um direito. Porém, essa análise do objeto da posse é refutada praticamente pela quase unanimidade dos autores em razão da teoria clássica do direito de propriedade entre as coisas corpóreas" 446 .

Para François Terré e Philippe Simler, pode haver também a posse de direitos reais (os direitos reais de usufruto e de servidão são suscetíveis de posse), também chamada de "quasi-possession" "447.

\subsection{DIREITO ANGLO-SAXÃO}

\subsubsection{A SEISIN-POSSESSION DA COMMON LAW}

Na common law o conceito de possession é usado em três sentidos distintos ${ }^{448}$ :

(a) significando a simples detenção física, comparada à posse natural dos romanos ou à detenção de Savigny, sendo mais uma situação de fato que uma noção jurídica. A lei não define as formas de início e fim da posse, mas pode esta ser entendida como a existência de uma relação tal da pessoa com a coisa que possibilite o exercício do uso ao seu prazer, permitindo ainda, com relação as outras pessoas, que a coisa fique sob a proteção de sua presença pessoal, de forma que a pessoa esteja na "posse física da coisa". Essa seria a "physical possession" da common law.

\footnotetext{
${ }^{446}$ Catherine Krief-Semitko. La valeur en droit civil français - essai sur les bien, la proprieté et la possession, p. 124.

${ }^{447}$ François Terré, Philippe Simler. Droit Civil - Les biens, p. 154.

${ }^{448}$ Frederick Pollock e Robert Samuel Wright. An essay on possession in the common law, p. 121.
} 
(b) usada para representar a posse no sentido jurídico, comparada com a possessio do Direito romano, descrevendo a relação legal ou jurídica da pessoa com a coisa, em vista de terceiros alheios a esta relação. Pode existir sem a posse física de fato (como, por exemplo, na situação em o homem se ausenta de sua casa, não deixando de deter a posse sobre ela).

(c) no Direito arcaico da common law, também usada para denotar o direito à posse (right to possession), que pode ser sinônimo da propriedade, ou outro direito temporário a ela relacionado $^{449}$.

Tradicionalmente, na common law, é sabido que, em disputas versando sobre a posse de terras, aquele que estava na posse presente da terra teria preferência na proteção, ou, dito de outra forma, ninguém poderia pleitear a posse de terra baseado no fato de já ter tido essa mesma posse no passado, o que está refletido na expressão "put into seisin".

Também é conhecido por "adverse possession" em common law o processo que resulta na transferência da propriedade, em decorrência da ocupação (posse) sobre a área. Quem adquire a propriedade de tal forma é conhecido por disseisor, e os direitos que adquire variam de acordo com as circunstâncias do caso, podendo envolver o fee simple title, mineral rights ou outros interests in real property. É necessário que a referida ocupação ocorra por um determinado período de tempo, que varia em cada jurisdição, mas sempre corresponde ao período de prescrição (statute of limitations) relativo ao direito do possuidor anterior - a posse ininterrupta durante um determinado prazo levaria à prescrição de eventual direito de reaver a área.

Assim, o procedimento da adverse possession, na common law, em razão de impor um prazo de prescrição à eventual direito que verse sobre a posse, acabava por sanear e remediar falhas e defeitos na titularidade sobre imóveis - e, com o passar do tempo, culminou com pacificação nas relações fundiárias, uma vez que um proprietário (beneficiado pela adverse possession) poderia finalmente restar tranquilo e seguro com a

\footnotetext{
${ }^{449} \mathrm{O}$ exemplo dado pelos autores consiste no homem que aluga seu cavalo por um mês a um cliente, que a empresta a um amigo, que envia um empregado para exercitar o cavalo no seu imóvel. O proprietário terá o right to possession (suspenso durante o prazo de um mês), o inquilino terá o right to possession por esse período de um mês. $\mathrm{O}$ amigo detém a posse enquanto subordinado ao cliente. E o empregado terá a posse física e nada mais.
} 
qualidade de seu título dominial, pois, caso contrário, eventuais herdeiros de antigos anteriores detentores da terra poderiam a qualquer tempo invocar direitos. Dito de outra forma, na common law a falta de defesa oportuna por parte do proprietário com relação a seu direito de propriedade poderia levar à perda permanente de seus direitos sobre o imóvel.

Por Adverse Possession (equivale à posse contrariada ou não autorizada, pois se há autorização para uso da terra, não há como invocar as regras da adverse possession) entende-se "uma forma pela qual o proprietário do imóvel perde seu direito sem receber nenhuma compensação em troca. Em razão de alterações na legislação registrária, a doutrina da adverse possession apresenta agora muito menos impacto. No entanto, quando aplicada, seus resultados são dramáticos (...). A quantidade limitada de terras sustenta a ideia que a terra é uma commodity escassa para permanecer sob a titularidade daquele que falhou, durante longo tempo, em assegurar o seu direito. Como já visto, também assegura a necessidade de manter o imóvel livre para ser objeto de transferência no mercado" ${ }^{450}$.

No ensinamento de Kevin e Susan Gray, "no decorrer de toda a história do direito imobiliário inglês, o conceito operacional tem abrangido a posse, em detrimento da propriedade: a maior preocupação do operador da common law tem sido com o fenômeno do controle do imóvel mediante a posse. Para o operador da common law o conceito de propriedade não ocupa o mesmo patamar de preocupação que a posse (...)"451. Como os demais doutrinadores da tradição latina, invocam também a necessidade de manutenção da paz social, mediante a preservação da situação primeira de posse: "Como imperativo da paz social, a posse encontra inúmeras menções desde a Magna Carta até a Convenção Europeia de Direitos Humanos".

Pela seisin-possession, como dito acima, era dada preferência à situação de fato da posse: "a noção de seisin reflete a orientação empírica da common law quando de seu início, que preferia analisar o direito sobre o imóvel a partir da noção de posse real sobre o imóvel do que dar prevalência à abstração encontrada em algum documento de título (...)", de forma que “(...) tal posse, mesmo que antijurídica, era beneficiada com certa proteção em razão

\footnotetext{
${ }^{450}$ Ben McFarlane, Nicholas Hopkins, Sarah Nield. Land Law - text, cases, and materials, p. 11.

${ }^{451}$ Kevin Gray, Susan Francis Gray. Elements of Land Law, p. 150.
} 
da 'manutenção da paz'”. Desta forma, indicam os autores que, se alguém, detendo tal seisin, fosse turbado em sua posse (em inglês, disseised), poderia buscar a recuperação da terra mediante ação específica, a chamada nouvel disseisin, que defenderia a posse (seisin) e não a propriedade, deixando claro Gray que "seisin was fact not right" 452.

\subsubsection{CONCEITO DE POSSE NA COMMON LAW}

A posse seria "um amalgama de componentes físicos e mentais, verificáveis externamente (...)", envolvendo os elementos material e subjetivo (já indicados nas teorias de Ihering e Savigny), “(...) ambos posse física e factual (corpus possessionis ou factum possessionis) e a intenção de possuir (animus possidendi). Ambos os elementos são necessários, apesar de tenderem a interagir intensamente". Continuam tais autores que posse é um fenômeno essencialmente externo e físico, importando a noção de que uma pessoa pode agir e se comportar como se fosse proprietário, o que por sua vez se reflete nos elementos físico e mental da ideia técnica e legal de posse. Percebe-se, assim, que vigora na common law inglesa a teoria subjetiva, que exige a presença do animus possidendi para a caracterização da posse. Mas, ainda assim, percebe-se que a jurisprudência mais recente prescinde do animus cada vez mais, o que desagrada a visão mais conservadora do fenômeno possessório. Os autores fazem um alerta sobre o perigo da caracterização da posse desprovida do animus: "Durante os anos mais recentes, entretanto, as cortes inglesas (diferentemente das cortes de common law do exterior) tem aderido, de certa forma não satisfatoriamente, em progressiva redução da importância do elemento intencional da posse. Assim, juízes têm perigosamente chegado perto de sugerir que uma demonstração positiva do animus possidendi não mais seria um elemento necessário ao conceito de posse" ${ }^{453}$.

Explica Wonnacott que o mais comum na Inglaterra é a posse ser adquirida ou acompanhada de outro título, como a propriedade, especialmente porque a terra na GrãBretanha ainda reflete fortemente suas origens feudais, chegando a dizer que não há terra sem proprietário na Inglaterra e Wales, sendo a Coroa (Crown), ou o rei, ainda a última instância de proprietário feudal de todo o reino, determinando este sistema feudal que

\footnotetext{
${ }^{452}$ Kevin Gray, Susan Francis Gray. Elements of Land Law, p. 151.

${ }^{453}$ Ibid., p. 160-161.
} 
todos os imóveis privados obtêm sua validação na outorga real. Sem essa outorga, a terra ainda pertenceria à Coroa (ao rei).

Na verdade, muitas vezes essa outorga real é fictícia, pois com o transcorrer dos anos, ficou impossível a demonstração e prova da existência da outorga. Então as cortes inglesas usam o próximo melhor meio para demonstrar a propriedade na ausência da outorga: a posse mais antiga, em uma presunção de que aquele que tem a posse mais antiga deve estar mais perto da eventual outorga real. Isso vale também para a antiguidade do título registrado.

Quanto mais antigo o registro, mais improvável se torna a hipótese de surgir outra pessoa com um título mais antigo e melhor ${ }^{454}$.

Nesse sentido, a base legal para a aquisição da titularidade pela adverse possession é a posse longa. O prazo para obter a titularidade sobre área possuída até a reforma de 2002 era de doze anos ${ }^{455}$.

Um caso jurisprudencial bastante interessante ocorreu na Inglaterra, em JA Pye (Oxford) Ltd. Versus Graham, no qual o casal Graham pleiteou com sucesso a usucapião de área de grande valor titulada e registrada em nome de JA Pye (Oxford) Ltd. Diante do deferimento do pedido a favor do caso Graham, a empresa recorreu contra o Estado Britânico à Corte Europeia de Direitos Humanos, argumentando que a legislação inglesa de adverse possession era contrária à Convenção Europeia de Direitos Humanos (ECHR), requerendo indenização pecuniária pela perda do seu imóvel. Todavia, a Câmara Alta da Corte Europeia de Direitos Humanos rejeitou o pedido.

Até a reforma provocada pela Land Registration Act de 2002, o ato anterior não distinguia áreas com titularidade registrada (registered land) de áreas sem titularidade registrada (unregistered land). A partir de 12 de outubro de 2003, o novo procedimento passou a vigorar e muito se parece com o procedimento imposto pela Lei $n^{0} 11.977 / 2009$ no Brasil, com o procedimento extrajudicial de usucapião, e estabeleceu procedimento

${ }^{454}$ Mark Wonnacott . Possession of land, p. 163.

${ }^{455}$ Ben McFarlane, Nicholas Hopkins, Sarah Nield. Land Law - text, cases, and materials, p. 320. 
diferenciado para as áreas com titularidade registrada, pois ocorreria o registro da nova titularidade em sede administrativa, após uma ocupação de dez anos, também garantindo "um mais adequado equilíbrio entre o proprietário registrado e o possuidor não autorizado $^{456,}$.

A maior razão para tal alteração na lei inglesa não se encontra diretamente na função social da propriedade, como princípio expressamente mencionado pela lei e doutrina inglesa, mas sim para a manutenção de um imóvel no comércio, como forma de evitar que certos bens fiquem excluídos da possibilidade de geração de riquezas.

No procedimento inglês, se o possuidor invasor permanece na posse originalmente não autorizada por dois anos após o protocolo do pedido de registro de sua situação, sem ação contrária do proprietário, poderá ao fim deste prazo requerer novamente o registro de sua titularidade, sem nova possibilidade de defesa por parte do proprietário anterior. Assim, o sistema inglês proporciona apenas uma chance de defesa ao proprietário registrado.

Todavia, o sistema inglês também passa a prestigiar a forma de aquisição da propriedade pelo registro, e não mais pela usucapião tradicional inglesa (a adverse possession), ao menos no tocante às terras com titularidade registrada (ou seja, na expressão em inglês: aquiring title to the land by registration, not by adverse possession itself).

Resta lembrar que para as área com titularidade não registrada continuam valendo as regras normais da adverse possession.

Assim, percebemos que a Land Regsitration Act de 2002 conferiu novo procedimento para a adverse possession, de que trataremos a seguir.

As regras abaixo refletem o contido na Seção 6, Parágrafos 1 a 4 do Land Registration Act inglês de 2002:

\footnotetext{
${ }^{456}$ Ben McFarlane, Nicholas Hopkins, Sarah Nield. Land Law - text, cases, and materials, p. 340.
} 
(a) pode-se requerer junto ao órgão Registrador o registro da titularidade de domínio, tendo por objeto um imóvel ali registrado, desde que o interessado detenha a posse sem autorização correspondente (adverse possession) por um período de dez anos, anteriores à data do requerimento.

(b) o órgão Registrador deverá proceder à citação dos seguintes interessados:

(i) o proprietário do imóvel;

(ii) o detentor de qualquer interesse registrado sobre o imóvel;

(iii) o locatário, caso exista locação;

(iv) qualquer interessado que detenha algum título registrado de acordo com a lei, e

(v) outros conforme determinação legal.

(c) qualquer dos citados acima poderá apresentar sua oposição, que envolve o despejo do ocupante, e análise do melhor título.

(iv) caso não haja oposição, o Registrador deverá registrar o requerente como o novo proprietário do imóvel.

Caso o adverse possessor, ao final do procedimento acima, tenha sucesso no registro da nova titularidade, nenhum antecessor terá qualquer outro direito sobre o imóvel ("the title is based on registration, not possession" ${ }^{\text {"457) }}$.

$\mathrm{O}$ ônus da prova de possuir um melhor título que o adverse possessor recai sobre o proprietário registrado, e ele terá o prazo de 65 dias úteis para tanto.

Caso o proprietário apresente oposição, o requerimento de registro será indeferido, e ele terá dois anos para obter o reapossamento da área. Caso não inicie tal procedimento, o adverse possessor poderá requerer novamente o registro de sua titularidade, sem que ocorra qualquer nova citação; ocorrerá simplesmente o registro da titularidade em nome do novo proprietário.

${ }^{457}$ Ben McFarlane, Nicholas Hopkins, Sarah Nield. Land Law - text, cases, and materials, p. 341. 
Os autores, no entanto, manifestam crítica e insatisfação ao novo sistema por ser intensamente favorável ao proprietário registrado. A Land Registration Act de 2002 tem sido descrita como enfraquecedora da usucapião (adverse possession) e criando a titularidade registrária virtualmente à prova de invasores. O âmbito de atuação da adverse possession foi reduzido às disputas pela definição de limites e descrições dos imóveis, e visa garantir que imóveis abandonados retornem ao mercado. 


\subsection{O REGISTRO DA POSSE NA LEGISLAÇÃO ESTRANGEIRA}

Existem experiências registrárias da posse em outras jurisdições, o que indica que podemos estar rumando no caminho certo no tratamento da matéria.

Ensina Asurmendi ${ }^{458}$ que na Espanha a prescrição aquisitiva de imóveis pode se dar pela (a) usucapião secundum tabulas, quando o imóvel se encontra registrado em nome do interessado no Registro de Imóveis; e (b) usucapião contra tabulas, quando o imóvel aparece em nome de um terceiro no Registro de Imóveis. Todavia, atualmente a legislação hipotecária vigente na Espanha não acolhe mais a usucapião tabular, sendo negado pela jurisprudência que a simples permanência de uma inscrição nos livros do Registro de Imóveis opere a usucapião, pois o entendimento é no sentido de que a existência da inscrição representa uma presunção iuris tantum, válida até que se prove o contrário.

Porém, ressalta Asurmendi que nem sempre foi assim, pois leis hipotecárias anteriores chegaram a permitir a usucapião tabular na Espanha, afirmando o autor que há previsão legal nesse sentido também na legislação alemã e suíça.

Assim, quatro períodos se destacam na Espanha, com relação ao registro da posse ${ }^{459}$ :

(a) 1861 e 1869. As primeiras leis hipotecárias tinham a finalidade de facilitar o acesso dos imóveis ao registro imobiliário, facilitando a inscrição da posse (art. 397 das Leis Hipotecárias de 1861 e 1869). Assim, o proprietário que carecia de um título de domínio formal podia, mediante prévia justificação, inscrever a posse, desde que não prejudicasse alguém que detivesse melhor título de propriedade, mesmo que não registrado.

Essa inscrição da posse no Registro Imobiliário tinha o condão de atribuir a presunção possessória, não somente com relação ao período posterior à inscrição, mas também pelo período anterior declarado no título, exceto se houvesse alguma contradição.

\footnotetext{
${ }^{458}$ Camino Sanciñena Asurmendi. La Usucapión Inmobiliaria, p. 251.

${ }^{459}$ Ibid., p. 252-254.
} 
Uma vez transcorridos 30 anos desde o início da posse, o detentor de uma posse inscrita poderia exercer a prescrição aquisitiva (civil) do domínio, de acordo com o artigo 403.2 da Lei de 1869.

(b) 1909. A lei de 1909 introduziu importantes mudanças, estabelecendo que a inscrição da posse produziria efeitos iguais ao domínio a favor do possuidor. Ademais, "a Lei Hipotecária de 1909 permitia a conversão da posse em inscrição de domínio, após transcorridos 30 anos, sempre que não houvesse outro registro posterior ou demanda que o afetasse ou contradissesse".

Essa conversão da inscrição da posse em inscrição de domínio tinha natureza registral. "Se tratava de uma prescrição tabular, que requeria o transcurso de 30 anos desde o registro. $\mathrm{O}$ fato da inscrição trazia a presunção da posse a favor do titular inscrito, caso no Registro não surgisse outra inscrição que contradissesse a anterior. $\mathrm{O}$ simples fato de não haver contradição seria suficiente para a conversão desta inscrição de posse em inscrição de domínio".

A jurisprudência também reconheceu essa prescrição tabular, indica Asurmendi, desde que houvesse o transcurso do prazo de 30 anos, com a conversão de direito para inscrição de domínio.

(c) 1927. Se a prescrição tabular havia sido reconhecida pela jurisprudência espanhola, a verdadeira usucapião tabular foi tipificada e introduzida pelo Decreto-Lei Real de 13 de junho de 1927, que causou a reforma na Lei Hipotecária de 1909; a mudança foi profunda, pois equiparou a inscrição de posse ao domínio para todos os efeitos de direito e também reduziu o prazo de 30 anos para 10 anos, assim a posse seria convertida em propriedade após transcorridos 10 anos.

A consequência foi a inclusão na lei da usucapião tabular; os mesmo requisitos foram mantidos, não poderia haver contestação à inscrição da posse, pois a inscrição indicava a presunção da posse e da boa-fé. 
(d) 1946. A Lei Hipotecária atualmente vigente na Espanha a partir de 8 de fevereiro de 1946 também trouxe grandes alterações. O seu artigo $5^{\circ}$ passou a proibir novas inscrições de mera posse no Registro Imobiliário, mantidos os direitos adquiridos originados na legislação anterior para as inscrições de posse ocorridas até $1^{\circ}$ de janeiro de 1945 (ou cujo procedimento tenha se iniciado anteriormente àquela data).

Como visto, a posse até certo momento foi passível de registro junto ao agente registrador espanhol, ou seja, a posse era objeto de inscrição no Registro da Propriedade; mas esta posição foi alterada, não sendo mais possível hoje o registro da posse na Espanha ${ }^{460}$.

A primeira Lei Hipotecária de 1861 admitiu a inscrição da posse como uma modalidade de direito transitório, permitindo ao proprietário que não teve o título de propriedade registrado obter esse registro mediante a justificação perante o juiz da comarca onde os bens se situassem. Assim era obtido o registro da posse, mas este registro não era oponível contra um terceiro que apresentasse melhor título de propriedade, mesmo que não registrado.

Com a edição do Decreto Real de 10 de fevereiro de 1875, tais inscrições possessórias provisórias passaram a ser definitivas, sendo este sistema mantido pela Lei Hipotecária de 1909.

Mas a abordagem legal da matéria sofre mudança radical com a edição da Lei e 30 de dezembro de $1944^{461}$, estabelecendo que o direito à posse (enquanto ius possessionis) não mais deveria alcançar a categoria de direito real. Assim, o simples senhorio ou a posse de fato deve ficar completamente apartada do registro, para evitar mais confusão no sistema e a produção de uma proteção jurídica estranha à natureza do bem protegido. A lei também assegurou o direito adquirido às posses inscritas até $1^{\circ}$ de janeiro de 1945, ou praticadas depois em razão de informações anteriores àquela data.

\footnotetext{
${ }^{460}$ Luis Díez-Picazo. Fundamentos del Derecho Civil Patrimonial III - las relaciones jurídico-reales, p. 393.

${ }^{461}$ Assim, esta lei indica que "os títulos referentes ao mero fato de possuir não serão inscritíveis", conforme artigo $5^{\circ}$. Luis Díez-Picazo. Fundamentos del Derecho Civil Patrimonial III - las relaciones jurídicoreales, p. 394.
} 
Também Jose Castan Tobeñas indica que, se tratando de posse e registro, em princípio cada um deles está situado em um mundo distinto e independente, virado um de costas para o outro ${ }^{462}$. Indica que na Espanha, com sua legislação hipotecária, a relação entre posse e registro imobiliário sempre foi um problema complexo.

Com a referida lei de 1861, como medida de direito transitória, após procedimentos de titulação, a posse poderia ser registrada; com o Decreto de 10 de fevereiro de 1875, deixa de ser um procedimento de direito transitório e passa a ser permanente; e por fim com a lei de 1909, a inscrição da posse passa a ser também um meio de "inmatriculacion" dos imóveis. Assim, como visto, em etapas anteriores, admitiu-se o registro da posse. Mas com a reforma hipotecária ocorrida em 1944 e 1946 essa possibilidade foi suprimida, especialmente porque se passou novamente a valorizar o ponto de vista teórico (sendo uma situação originada do fato, escapa da área de proteção do sistema registral imobiliário); outras razões práticas também pesaram, pois o governo espanhol a partir de 1934 criou outras formas para facilitar o registro de títulos autênticos.

Também Valdecasas menciona que a presunção da posse a favor do titular inscrito foi introduzida pela Lei de 21 de abril de 1909, que pretendeu fortalecer a eficácia da inscrição, "conferindo ao titular inscrito um direito à posse passível de efetividade em juízo sumaríssimo, sem necessidade de buscar o juízo declarativo"463.

No Direito português, “o registro da posse, possível nos termos da alínea 'e' do n. 1 do artigo 2 do Código do Registro Predial, torna a posse pública”, ensina ainda Ascensão; ademais, o art. 1295, n. 2 do Código Civil português impõe "para o registro da mera posse, sentença passada em julgado, na qual se reconheça que o possuidor tem possuído pacífica e publicamente por tempo não inferior a cinco anos. Temos assim de concluir que uma posse registrada terá de ser havida por posse pública enquanto esse registro subsistir".

\footnotetext{
462 Jose Castan Tobeñas. Derecho Civil Español, Comun y Foral, p. 719.

${ }^{463}$ Guillermo G. Valdecasas. La posesión, p. 80.
} 
Nas palavras do aludido mestre português “o possuidor só pode obter o título judicial para registro da posse desde que tenha possuído publica e pacificamente por tempo não inferior a cinco anos (art. 1295, n. 2),464.

No tocante ao Direito germânico, o moderno Direito Imobiliário, a posse teria perdido a sua virtude de representar e fazer notório (público) o direito real, ficando substituída deste pela inscrição no registro imobiliário ${ }^{465}$.

No que se refere aos direitos que são passíveis de registro junto ao Registro Imobiliário, Wolff indica que "o registro imobiliário somente é acessível à determinadas inscrições. Com exceção das indicações fáticas que se prestam à individualização e especificação do imóvel $^{466}$, somente são inscritíveis os direitos reais sobre o imóvel ou sobre um direito imobiliário (também inscritível), as limitações à livre disposição a favor de alguém, as anotações preventivas e os assentos de contradição; não havendo menção à posse"467.

No Ddireito germânico ${ }^{468}$, pode ocorrer ainda a usucapião tabular, com a inscrição de um título no Registro Imobiliário que não propriamente teria juridicidade suficiente para prevalecer (como, por exemplo, em caso de um contrato nulo) em caso de uma impugnação de outro melhor direito, com o transcurso do prazo de trinta anos. Ou seja, o suposto título deve permanecer inscrito por trinta anos, sem sofrer nenhuma impugnação que o contradiga.

Nesse sentido, indica Wolff que "o titular pode impugnar a contradição entre a situação inscrita e a real. Se ele omite a impugnação durante certo tempo, seu silêncio fará prevalecer ao final o que consta do Registro Imobiliário: o titular perde seu direito, por ter permanecido em silêncio, e a aparência se converte em realidade"; consistindo esta conversão na usucapião segundo registro (ou usucapião tabular). Existem limites ao instituo; ainda assim somente podem ser usucapidos os direitos reais que possibilitem a posse de uma coisa ou direito, como, por exemplo, a propriedade, a superfície e as

\footnotetext{
${ }^{464}$ José Alberto C. Vieira. Direitos Reais, p. 576-578.

${ }^{465}$ Martin Wolff. Tratado de Derecho Civil, Tomo Terceiro - Derecho de Cosas, V. I, p. 26.

${ }^{466}$ Como exemplos de inscrições fáticas temos as características do imóvel, sua exploração econômica (terras produtivas), edifícios existentes, renda e preço de aquisição. (p. 155).

${ }^{467}$ Martin Wolff. Tratado de Derecho Civil, Tomo Terceiro - Derecho de Cosas, V. I, p. 156.

${ }^{468}$ Ibid., p. 287.
} 
servidões (e não os direitos reais de garantia, encargos e preempção). Ao mesmo tempo, necessário ainda a permanência na posse do bem ou direito pelo prazo de trinta anos ${ }^{469}$. Não há necessidade, portanto, de justo título ou boa-fé; mas a inscrição do título será necessária à ocorrência da usucapião.

Todavia, percebemos hoje, nos países mais avançados, um estranho fenômeno de decadência do instituto da posse, com a redução significativa de sua importância para o direito e para a sociedade, até mesmo em relação à propriedade registrada.

Revela Jose Castan Tobeñas que a posse tem perdido importância nas jurisdições que lhe negam eficácia registrária; mas de qualquer forma a posse continua sua evolução, como manifestação da realidade jurídica, mesmo que fora do Registro Imobiliário ${ }^{470}$.

O importante doutrinador português Manuel Rodrigues também considera a posse um instituto em decadência, pois percebe (a) um aperfeiçoamento dos meios de defesa dos direitos; (b) que se torna mais fácil demonstrar a titularidade de direitos; (c) que a justiça se torna menos morosa; e (d) que a existência de um cadastro da propriedade afasta dúvidas $^{471}$.

Ressalva Hernández Gil que não crê no declínio da posse, mas sim na sua mutabilidade, lembrando justamente das massas de despossuídos que poderiam se beneficiar do instituto, buscando a participação equilibrada de todos nos recursos coletivos ${ }^{472}$.

\footnotetext{
${ }^{469}$ Ou seja, para ocorrer a usucapião da propriedade, necessário estar na posse em nome próprio pelos trinta anos; possuir a título de usufruto para adquirir o usufruto; possuir o direito para adquirir uma servidão de passagem (p. 287).

${ }_{470}$ Jose Castan Tobeñas. Derecho Civil Español, Comun y Foral, p. 653.

${ }^{471}$ Manuel Rodrigues. A posse - Estudo de Direito Civil Português, p. 9.

${ }^{472}$ António Hernández Gil. La función social de la posesión (ensayo de teorización sociológico-jurídica), p. 208.
} 


\section{A QUESTÃO DA OCUPAÇÃO DE IMÓVEIS RURAIS POR ESTRANGEIROS}

Passaremos a traçar uma visão geral acerca dos aspectos legais relativos à aquisição e ocupação (posse), em nosso país, de imóvel rural por estrangeiros e sociedades brasileiras com a maioria do capital detida por estrangeiros (denominadas Sociedades Brasileiras Sujeitas à Restrição), especialmente em vista da decisão proferida pelo Conselho Nacional de Justiça - CNJ nos autos do processo $\mathrm{n}^{\circ}$ 0002981-80.2010.2.00.0000, além da nova interpretação emitida pela Advocacia-Geral da União, a qual alterou a interpretação e recuperou a validade de alguns dispositivos das principais normas que regem a matéria.

Inicialmente, é importante apresentar uma visão geral histórica da interpretação e aplicação das referidas normas regedoras, desde sua edição.

A Lei $n^{\circ} 5.709$, de 7 de outubro de 1971, e seu regulamento, o Decreto ${ }^{\circ} 74.965$, de 26 de novembro de 1974, impuseram limitações à aquisição de imóveis rurais por pessoas físicas ou jurídicas estrangeiras (art. $1^{\circ}$ da Lei $\mathrm{n}^{\circ} 5.709 / 71$ ), estabelecendo o $1^{\circ}$ parágrafo, do artigo $1^{\circ}$, da Lei ${ }^{\circ} 5.709 / 71$ que os limites e restrições aplicáveis à aquisição de imóveis rurais por empresas estrangeiras autorizadas a funcionar no Brasil também são aplicáveis à "pessoa jurídica brasileira da qual participem, a qualquer título, pessoas estrangeiras, físicas ou jurídicas, que tenham a maioria do seu capital social e residam ou tenham sede no exterior".

De forma geral, a aquisição de imóveis rurais por estrangeiros e Sociedades Brasileiras Sujeitas à Restrição poderia ser feita com as seguintes restrições: (a) finalidade de uso: (a.i) tais entes poderiam adquirir imóveis rurais destinados à implantação de projetos agrícolas, pecuários, industriais, ou de colonização ${ }^{473}$, vinculados aos seus objetivos estatutários, mas a aquisição ficava sujeita à autorização prévia do Ministério da Agricultura, bem como de outros órgãos competentes, dependendo da natureza das atividades (INCRA, Ministério da

\footnotetext{
${ }^{473}$ Nos loteamentos rurais efetuados por empresas particulares de colonização, assim entendidas aquelas que tenham por finalidade executar programa de valorização de área ou distribuição de terras (art. 13 da Lei $\mathrm{n}^{\circ}$ $5.709 / 71$ ), a aquisição e ocupação de, no mínimo, $30 \%$ da área, serão feitas obrigatoriamente por brasileiros (art. $4^{\circ}$ da Lei $\left.{ }^{\circ} 5.709 / 71\right)$.
} 
Indústria e Comércio, dentre outros); (b) com relação ao tamanho da área, as pessoas da mesma nacionalidade não poderão ser proprietárias de mais de $10 \%$ da superfície do município (art. 12, $\S 1^{\circ}$, da Lei $\mathrm{n}^{\circ} 5.709 / 71$ ) e a soma das áreas rurais não poderá ultrapassar $25 \%$ da superfície dos municípios (art. 12 da Lei n $\left.{ }^{\circ} 5.709 / 71\right)^{474}$.

A aquisição de área superior a 100 módulos de exploração indefinida ${ }^{475}$ (que poderá variar dependendo das características fundiárias de cada região do Brasil), dependerá da

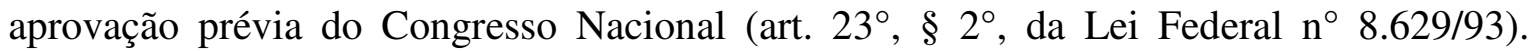
Existem restrições específicas aplicáveis às pessoas físicas estrangeiras: a aquisição de imóvel rural com área superior a 3 módulos (ou a aquisição de mais de um imóvel, com área inferior a 3 módulos, cuja somatória ultrapasse esse patamar) deve ser previamente aprovada pelo INCRA e a aquisição de imóvel rural por pessoa física estrangeira não poderá exceder a 50 módulos de exploração indefinida, em área contínua ou descontínua (art. $3^{\circ}$ da Lei $\left.n^{\circ} 5.709 / 71\right)$.

As referidas restrições e limitações também são aplicáveis em caso de arrendamento de imóveis rurais por pessoas físicas ou jurídicas estrangeiras residentes no Brasil e/ou Sociedades Brasileiras Sujeitas à Restrição, conforme previsto no parágrafo $1^{\circ}$ do artigo 23 da Lei Federal nº 8.629/93.

\subsection{RETROSPECTO LEGAL E MUDANÇA DO MARCO REGULATÓRIO}

A Lei $n^{\circ}$ 8.629, de fevereiro de 1993, estabeleceu que também é aplicada a restrição citada no item anterior ao arrendamento de propriedade rural por estrangeiros ( $\$ 1^{\circ}$ do art. 23$) \mathrm{e}$ que a aquisição ou o arrendamento de propriedade rural superior a 100 módulos de exploração indefinida devem ser previamente aprovados pelo Congresso Nacional,

\footnotetext{
${ }^{474}$ Existem exceções, conforme disposto no $\S 2^{\circ}$ do artigo $5^{\circ}$ do Decreto $n^{\circ} 74.965 / 74$, que ficam excluídas das restrições.

${ }^{475}$ Módulo de Exploração Indefinida (MEI) é uma unidade de medida, em hectares, baseada no conceito de módulo rural, determinado pela legislação da Unidade Federativa onde o imóvel rural está localizado, e estabelecida segundo características econômicas e ambientais específicas da região onde o imóvel rural está localizado, levando em consideração a natureza da atividade agrícola que é desenvolvida em referida área. De acordo com a legislação aplicável, o INCRA é o órgão competente para estabelecer e modificar as dimensões do MEI.
} 
ficando, dessa forma, regulamentada a Lei $n^{\circ}$ 5.709/71 e as restrições relativas aos imóveis rurais.

Discorremos já no item 5 acima sobre a definição de imóvel rural.

Determinou o parecer AGU/LA-04/94, emitido pela Advocacia Geral da União, que o $\S 1^{\circ}$ do artigo $1^{\circ}$ da Lei $n^{\circ} 5.709 / 71$ não foi recepcionado pela Constituição Federal de 1988 e, portanto, não haveria tratamento desigual entre sociedades brasileiras, constituídas de acordo com as leis do Brasil, em razão da origem de seu capital social.

Quando da publicação da Emenda Constitucional $n^{\circ}$ 6, que ocasionou a revogação do artigo 171 da Constituição Federal de 1988, no qual constava a definição de empresa brasileira, reafirmou a Advocacia-Geral da União o mesmo parecer, ou seja, que o $\S 1^{\circ}$ do artigo $1^{\circ}$ da Lei ${ }^{\circ} 5.709 / 71$ não foi recepcionado pela Constituição Federal de 1988. Desta forma, em 17 de março de 1997, a AGU emitiu o parecer CG-181, que também foi aprovado pelo Presidente, em 17 de dezembro de 1998, tornando-se vinculativo às repartições e órgãos da Administração Pública Federal.

Até 22 de agosto de 2010, o parecer da AGU CQ-181/1997 estava em vigor. Assim sendo, a posição adotada era a de que os limites e as restrições estabelecidos na Lei Federal $n^{\circ} 5.709 / 71$, no Decreto $n^{\circ} 74.965 / 74$ e na Lei Federal n 8.629/93 não eram aplicáveis às empresas brasileiras, ainda que elas tivessem participação de estrangeiros (pessoas físicas ou jurídicas), qualquer que fosse a origem do capital social.

No entanto, a própria Consultoria-Geral da União emitiu um novo parecer (CGU/AGU001-RVJ), em 3 de setembro de 2008, contrariando e revogando expressamente o parecer anterior e sustentando que o parágrafo $1^{\circ}$ do artigo $1^{\circ}$ da Lei $n^{\circ} 5.709 / 71$ foi sim recepcionado pela Constituição Federal de 1988. Este novo parecer foi aprovado pelo Presidente da República e publicado em 23 de agosto de 2010 no Diário Oficial da União (“Parecer de 2010”), gerando grande insegurança jurídica.

Trazendo à tona uma nova abordagem acerca da aquisição de imóveis rurais por empresas brasileiras com a participação de estrangeiros, o parecer de 2010 fundamentou-se no 
princípio da soberania nacional aplicável à ordem econômica, bem como nas alegadas mudanças que recentemente ocorreram no cenário social e econômico do Brasil e no aumento dos preços dos produtos agrícolas, na crise mundial de alimentos e na possibilidade de adoção do biocombustível em larga escala como fonte de energia alternativa.

O parecer de 2010 voltou a estender às empresas brasileiras, nas quais a maioria do capital social ${ }^{476}$ e/ou o controle societário é detido por estrangeiros, pessoas físicas ou jurídicas, no que tange à aquisição de imóveis rurais por estrangeiros, os mesmos limites e restrições impostos pela Lei Federal n ${ }^{\circ} 5.709 / 71$. Ele é inteiramente baseado no argumento de que a Lei Federal n 5.709/71 teria sido recepcionada pela atual Constituição Federal de 1988.

Assim, o parecer de 2010 da AGU promove o reexame do artigo $1^{\circ}$ e seu parágrafo $1^{\circ}$ da Lei Federal n 5.709/71, o qual estabelece que:

Artigo $1^{\circ}$ - $\mathrm{O}$ estrangeiro residente no País e a pessoa jurídica estrangeira autorizada a funcionar no Brasil só poderão adquirir imóvel rural na forma prevista nesta Lei.

$\S 1^{\circ}$ - Fica, todavia, sujeita ao regime estabelecido por esta Lei a pessoa jurídica brasileira da qual participem, a qualquer título, pessoas estrangeiras físicas ou jurídicas que tenham a maioria do seu capital social e residam ou tenham sede no exterior. (grifo nosso)

Nesse sentido, na interpretação do parecer de 2010, o referido dispositivo legal equipara certos tipos de pessoas jurídicas brasileiras aos estrangeiros, para a aquisição de imóveis rurais, indicando que tal dispositivo é claro ao dizer que ficarão sujeitas às restrições legais as pessoas jurídicas brasileiras das quais participem, a qualquer título, pessoas estrangeiras físicas ou jurídicas que tenham a maioria do seu capital social e residam ou tenham sede no exterior. Desta forma, também estão incluídas nas restrições apontadas, e sujeitas às 
mesmas consequências, as aquisições indiretas de imóvel rural, como, por exemplo, pela via societária.

Ademais, a AGU, em uma interpretação extensiva, afirmou, no parecer de 2010, que o conceito de "maioria do capital social", mencionado no parágrafo $1^{\circ}$ do artigo $1^{\circ}$ da Lei Federal $\mathrm{n}^{\circ} 5.709 / 71^{477}$, deve ser entendido como "controle acionário" sobre a empresa em questão. Ademais, ele também afirma que o conceito de "a qualquer título", deve ser interpretado tanto como participação direta quanto indireta das Sociedades Brasileiras Sujeitas à Restrição.

Pelo parecer de 2010, a equiparação da pessoa jurídica brasileira e da pessoa jurídica estrangeira, para fins da Lei Federal $\mathrm{n}^{\circ}$ 5.709/71, ocorre nas seguintes hipóteses cumulativas:

(a) o estrangeiro, pessoa física, seja não residente, ou a pessoa jurídica não possua sede no país;

(b) o estrangeiro, pessoa física ou jurídica, descrito no item "i" acima, participe, a qualquer título, de pessoa jurídica brasileira (direta ou indiretamente). A expressão "a qualquer título" deve ser lida como abrangente da participação direta ou indireta que uma pessoa física ou jurídica estrangeira, nos termos acima explicitados, em uma pessoa jurídica brasileira, que irá adquirir imóveis rurais no Brasil; e

(c) essa participação deve assegurar a seus detentores o poder de conduzir as deliberações da assembleia geral, de eleger a maioria dos administradores da companhia e de dirigir as atividades sociais e orientar o funcionamento dos órgãos da companhia (controle societário). Exige que o estrangeiro seja o acionista controlador da pessoa jurídica brasileira, seja por meio de controle majoritário, seja compartilhado ou minoritário.

\footnotetext{
${ }^{477}$ Artigo $1^{\circ}$ - O estrangeiro residente no País e a pessoa jurídica estrangeira autorizada a funcionar no Brasil só poderão adquirir imóvel rural na forma prevista nesta Lei.

$\S 1^{\circ}$ - Fica, todavia, sujeita ao regime estabelecido por esta Lei a pessoa jurídica brasileira da qual participem, a qualquer título, pessoas estrangeiras físicas ou jurídicas que tenham a maioria do seu capital social e residam ou tenham sede no exterior.
} 
Assim, impõe-se verificar, para aferir se a pessoa jurídica brasileira, com participação direta ou indireta de capital estrangeiro, está sujeita às restrições da Lei Federal $\mathrm{n}^{\circ}$ 5.709/71, se tal pessoa jurídica é controlada, direta ou indiretamente, por estrangeiro (i.e., pessoa física não residente ou pessoa jurídica que não possua sede no país). A aferição da efetiva existência de controle pelo estrangeiro é bastante casuística e subjetiva, havendo muito espaço para interpretação por parte dos órgãos governamentais, o que também gera insegurança jurídica.

De acordo com artigo 20 do Decreto $n^{\circ} 74.965 / 74^{478}$ e com o parecer de 2010, conclui-se que as aquisições de imóveis rurais, direta ou indiretamente (i.e. pela via societária), por Sociedades Brasileiras Sujeitas à Restrição, a qualquer título, devem respeitar as restrições previstas na Lei Federal $n^{\circ} 5.709 / 71$ e no Decreto $n^{\circ} 74.965 / 74$, sob pena de serem consideradas nulas de pleno direito (art. 15 da Lei Federal n ${ }^{\circ}$ 5.709/71).

Uma vez publicado no Diário Oficial da União e aprovado pelo Presidente da República, o parecer de 2010 vincula toda a Administração Pública Federal, direta e indireta e as autarquias federais, incluindo-se o INCRA, os Registros de Imóveis, os Tabelionatos de Notas e as Juntas Comercias, dentre outros, nos termos do o artigo 40 da Lei Complementar $n^{\circ} 73 / 93$.

Por fim, destacamos que está expressamente mencionado no parecer de 2010 que os seus efeitos devem ser produzidos a partir de sua publicação no Diário Oficial da União, sendo, nos termos de legislação aplicável, vedada a aplicação retroativa da nova interpretação.

Ainda, destacamos que a Lei ${ }^{\circ} 5.709 / 71$ (arts. 10 e 11) e o Decreto $n^{\circ} 74.965 / 74$ (arts 15 e 16) estabelecem que os Cartórios de Registro de Imóveis manterão cadastro especial, em livro auxiliar, das aquisições de imóvel rural feitas por estrangeiros e Sociedades Brasileiras Sujeitas à Restrição, no qual deverá constar: (i) a carteira de identidade da pessoa física ou os atos de constituição no caso de pessoas jurídicas; (ii) o memorial descritivo do imóvel, sua área, suas características, seus limites e suas confrontações; (iii) a

\footnotetext{
${ }^{478}$ Art. 20 - As normas regulamento aplicam-se a qualquer alienação de imóvel rural para pessoa física ou jurídica estrangeira, em casos como o de fusão ou incorporação de empresas, de alteração do controle acionário da sociedade, ou de transformação de pessoa jurídica nacional para pessoa jurídica estrangeira.
} 
transcrição da autorização da autoridade competente, quando for o caso, e (iv) as exceções do $\S 2^{\circ}$, artigo $5^{\circ}$ do Decreto ${ }^{\circ} 74.965 / 74$.

Os Cartórios de Registro de Imóveis são obrigados a remeter trimestralmente, sob pena de perda do cargo, à Corregedoria da Justiça dos Estados a que estiverem subordinados e à repartição estadual do INCRA, e também ao Conselho de Defesa Nacional, com relação à aquisição de imóveis rurais situados em áreas consideradas indispensáveis à segurança nacional, uma relação das aquisições relativas ao período em questão.

Baseado no parecer de 2010 e na decisão do TCU acima mencionada, o Conselho Nacional de Justiça, mediante solicitação expressa da Procuradoria da República, recomendou que os Cartórios de Registro de Imóveis passem a observar as restrições das normas reguladoras da matéria inclusive com relação às Sociedades Brasileiras Sujeitas à Restrição, reforçando, na prática, a aplicação do $\S 1^{\circ}$ do artigo $1^{\circ}$ da Lei $n^{\circ} 5.709 / 71$.

Como já mencionado, qualquer aquisição de imóvel rural, sem a observância das normas reguladoras da matéria está sujeita à nulidade, sendo o tabelião de notas que lavrar a escritura e o oficial de registro que a registrar civil e criminalmente responsáveis pela infração. Além disso, o vendedor ficará obrigado a devolver ao comprador o valor pago pela aquisição.

Especificamente no Estado de São Paulo houve a publicação do parecer no 461/2012-E, em 11 de dezembro de 2012 ("Parecer CGJ-SP”), emitido pela Corregedoria-Geral de Justiça do Estado de São Paulo, com força normativa, concluindo, diferentemente do parecer de 2010, que o parágrafo $1^{\circ}$ do artigo $1^{\circ}$ da Lei Federal $n^{\circ} 5.709 / 71$ não foi recepcionado pela Constituição Federal de 1988. A orientação indicada por tal parecer é a de dispensar os registradores e notários do Estado de São Paulo de seguirem a orientação da AGU em relação às determinações da Lei $n^{\circ}$ 5.709/71 e do Decreto $n^{\circ} 74.965 / 74$.

O parecer CGJ-SP seria vinculativo aos Tabeliães e aos Oficiais de Registro de Imóveis do Estado de São Paulo, orientando-os a não mais observar as restrições e as determinações impostas pela lei mencionada acima com relação à aquisição ou arrendamento de imóveis rurais por pessoas jurídicas brasileiras cuja maioria do capital social se concentre em poder 
de estrangeiros residentes fora do Brasil ou de pessoas jurídicas com sede no exterior, mas não será vinculativo aos órgãos federais,como o INCRA e a Secretaria da Receita Federal, que também detêm e organizam cadastros sobre os imóveis rurais. Esse conflito de competência para regular a matéria acrescentou ainda mais insegurança jurídica à questão, resultando na inércia dos Cartórios até que uma decisão final seja proferida.

Assim, de forma a questionar e cancelar o parecer CGJ-SP, o INCRA e o governo federal impetraram Mandado de Segurança, tendo o Tribunal Regional Federal da $3^{\text {a }}$ Região concedido, em 3 de maio de 2013, uma liminar para suspender os efeitos do ato normativo veiculado no parecer CGJ-SP. Porém, em 28 de agosto de 2013, houve o julgamento do referido Mandado de Segurança, no qual o Tribunal Regional Federal da $3^{\text {a }}$ Região declarou-se incompetente para analisar a questão e consequentemente revogou a liminar anteriormente concedida que determinava a suspensão dos efeitos do parecer CGJ-SP. Salientamos que tal questão ainda será discutida no Tribunal de Justiça de São Paulo, não tendo havido até o momento nenhuma decisão acerca deste mérito.

Para regulamentar o procedimento administrativo do pedido de autorização para aquisição e arrendamento de imóvel rural em todo território nacional, por pessoa natural e jurídica estrangeira, bem como por Sociedades Brasileiras Sujeitas à Restrição, o INCRA publicou a Instrução Normativa $n^{\circ}$ 76, em 23 de agosto de 2013 e os Ministros de Estado do Desenvolvimento, Agrário - MDA, da Agricultura, Pecuária e Abastecimento - MAPA, do Desenvolvimento Indústria e Comércio Exterior - MDIC e do Turismo, em conjunto com o INCRA, publicaram a Instrução Normativa Conjunta n 1 , em 27 de setembro de 2012.

Em suma, o requerente deverá instruir o pedido com documentos que comprovem: (i) a justificativa de proporcionalidade entre o quantitativo de terras visado e a dimensão do projeto; (ii) o cronograma físico e financeiro do investimento e da implementação; (iii) eventual utilização de crédito oficial no financiamento parcial ou total do empreendimento; (iv) a viabilidade logística de sua execução, e, no caso de projeto industrial, a demonstração da compatibilidade entre o(s) local(s) da(s) planta(s) industrial(s) e a localização geográfica das terras; (v) a demonstração de compatibilidade com os critérios para o Zoneamento Ecológico Econômico do Brasil, referentes à localidade do imóvel, quando houver. 
O requerimento deve ser enviado à Superintendência Regional do INCRA no Estado de localização do imóvel rural que, após prévia análise, será remetido: (i) ao Ministério do Desenvolvimento Agrário, tratando-se de atividade de colonização ou (ii) ao Ministério da Agricultura, Pecuária e Abastecimento, quando tratar-se de atividade agrícola, pecuária ou assemelhada para autorização de aquisição ou arrendamento por pessoa natural estrangeira; (iii) ao Ministério do Desenvolvimento, Indústria e Comércio Exterior, tratando-se de atividade de caráter industrial ou agroindustrial; (iv) ao Ministério do Turismo, se o projeto apresentado envolver empreendimentos turísticos; ou (iv) a outro órgão ou entidade eventualmente competente para em parte ou no todo apreciar tecnicamente o objeto do empreendimento.

Ainda, deverão obter a aprovação prévia adicional de outros órgãos nos seguintes casos: (i) imóvel situado em faixa de fronteira ou em área considerada indispensável à segurança nacional, que deverá obter a aprovação pela Secretaria-Geral do Conselho de Defesa Nacional; (ii) imóveis localizados na linha litorânea brasileira (imóveis de marinha); (iii) imóveis localizados na região amazônica; e (iv) nos casos em que se faça necessária prévia autorização do Congresso Nacional, os autos serão encaminhados à Casa Civil da Presidência da República (art. $7^{\circ}$, II e III, da Instrução Normativa Conjunta ${ }^{\circ} 1$ ).

Após análise e manifestação do órgão ou entidade consultada, os autos serão encaminhados novamente ao INCRA que decidirá sobre o pedido de autorização para aquisição ou arrendamento de imóvel rural, formulado por pessoa natural ou jurídica estrangeira ou equiparada (art. $8^{\circ}$ da Instrução Normativa Conjunta $n^{\circ} 1$ ).

\subsection{TOMADA DE POSIÇÃO}

A discussão causada pelo novo parecer da Advocacia-Geral da União a respeito da aquisição e ocupação de terras rurais por estrangeiros despertou controvérsias e voltou a pautar um tema jurídico-econômico que já recebeu tratamento legal, ainda no início da década de 1970, com a edição da Lei 5.709, que regula os procedimentos de compra e venda de terras. Os tempos eram outros e a preocupação política então era o controle, ou seja, a aquisição de terras rurais acima de determinada metragem apenas seria possível 
após autorização governamental, resultando em procedimento complexo pouco ou nada usado nos anos seguintes. O controle também chegava à origem do capital, já que empresas brasileiras com a maioria do seu capital social detido por estrangeiros também deveriam obter previamente a autorização.

Já na década de 1990, o cenário começa a ser alterado por razões econômicas, pois o Brasil iniciava a sua abertura ao mundo e necessitava de investimentos. Buscou-se a facilitação para o ingresso de capitais e o substrato jurídico foi alterado, especialmente com o advento da Emenda Constitucional nº 6, de 1995, e do parecer CG-181 da AGU, de 1997, que levaram à equiparação entre empresa brasileira e a empresa brasileira detida por capital estrangeiro. Prevaleceu desta forma o princípio da isonomia por 14 anos, período em que inúmeras aquisições de terras rurais com capitais externos ocorreram.

Essa situação perdurou até agosto de 2010, quando o novo parecer da AGU revogou o anterior, que vigorou por mais de uma década, e mudou o marco regulatório sobre a realização de investimentos no agronegócio brasileiro. Até então, não havia restrições à aquisição ou ao arrendamento de terras rurais, desde que a empresa adquirente fosse constituída no Brasil, independentemente da origem de seu capital.

Durante os anos de vigência do parecer da AGU então revogado, inúmeros negócios foram, de fato, formalizados. Consequentemente, estes negócios foram revestidos de juridicidade, consistindo em atos jurídicos perfeitos e, como tais, protegidos pela Constituição. Esta situação até então estável foi ameaçada por mudanças nas regras, ou, mais propriamente, na verdade jurídica que até então prevalecia, da igualdade entre empresas brasileiras, independentemente da origem do capital.

A preocupação do governo com esta situação foi acentuada a partir de 2008, quando começou a busca por fórmulas para reverter este quadro. Com a publicação do novo parecer da AGU e sua aprovação pela Presidência da República, o documento adquiriu força similar à da lei, vinculando a Administração Pública, e reinterpretou a visão de 1997 em sentido diametralmente oposto: agora também a empresa brasileira detida por capital estrangeiro deve requerer autorização. 
Desta maneira, uma empresa brasileira com maioria de capital estrangeiro não poderá comprar terras rurais sem autorização prévia do governo federal, do Congresso Nacional e/ou do INCRA. Além disso, há ainda limites máximos dentro de cada município que podem ser objeto de aquisição por estrangeiros, ou sociedades brasileiras com maioria do capital ou controle detido por estrangeiros.

O anúncio desse novo parecer teve como resultado prático a suspensão dos investimentos por empresas com essas características e à espera de nova regulamentação. O impacto foi imediato e estima-se que alguns bilhões em investimentos no setor agroindustrial estejam suspensos, em vista do cenário de incertezas jurídicas criado.

É necessário estabelecer urgentemente novo marco para a matéria, traduzindo e refletindo os anseios da sociedade brasileira, de modo a equilibrar de maneira mais racional dois valores importantíssimos: a segurança nacional e o desenvolvimento econômico do país. Não se pode continuar com a atual situação de incerteza jurídica; a questão deve ser de uma vez por todas tratada e definida pelo Congresso Nacional. 


\section{NOVA DISCIPLINA DA POSSE CONFERIDA PELA LEI No 11.977/2009}

A Lei 11.977, de 7 de julho de 2009, está divida em três principais capítulos: o primeiro dedicado à instituição do programa Minha Casa Minha Vida (MCMV); o segundo tratando do Registro Eletrônico e das Custas e Emolumentos; e o terceiro, tratando da Regularização Fundiária de Assentamentos Urbanos.

O capítulo III, por sua vez, encontra-se subdividido em quatro seções: (i) Seção I, contendo as Disposições Preliminares; (ii) Seção II, tratando da Regularização Fundiária de Interesse Social; (iii) Seção III, versando sobre a Regularização Fundiária de Interesse Específico; e (iv) Seção IV, tratando do Registro da Regularização Fundiária.

Inicialmente, a regularização fundiária consiste no conjunto de medidas jurídicas, urbanísticas, ambientais e sociais que visam à regularização de assentamentos irregulares e à titulação de seus ocupantes. A competência é municipal para dispor sobre o procedimento de regularização fundiária. Em linhas gerais, por demarcação urbanística entende-se o procedimento administrativo pelo qual o Poder Público, no âmbito da regularização fundiária de interesse social, demarca imóvel de domínio público ou privado, definindo seus limites, sua área, sua localização e seus confrontantes, com a finalidade de identificar seus ocupantes e qualificar a natureza e o tempo das respectivas posses.

Por sua vez, legitimação de posse consiste no ato do Poder Público destinado a conferir título de reconhecimento de posse de imóvel objeto de demarcação urbanística, com a identificação do ocupante, do tempo e da natureza da posse.

Trataremos a seguir de todo este procedimento e seu encaminhado mediante processo administrativo, junto aos cartórios de registro de imóveis.

Importante desde logo apontar o aspecto mais relevante sob o ponto de vista jurídico: após o registro do parcelamento no âmbito da regularização urbanística, o Poder Público concederá título de legitimação de posse aos ocupantes cadastrados (preferencialmente em 
nome da mulher), que será registrado, como posse, no Cartório de Registro de Imóveis eis um aspecto bastante inovador da lei.

O resultado deste registro da posse será, sem prejuízo dos direitos decorrentes da posse exercida anteriormente, possibilitar ao detentor do título de legitimação de posse, após cinco anos de seu registro, o requerimento ao Oficial de Registro de Imóveis da conversão desse título em registro de propriedade, tendo em vista sua aquisição por usucapião instituindo a usucapião administrativa.

Ficaria também afastada a preocupação com eventual inconstitucionalidade na criação da usucapião administrativa, desde que respeitadas as regras constitucionais a respeito dessa matéria, bem como não ocorra o afastamento do Poder Judiciário, podendo este ser invocado a qualquer tempo, se necessário.

Como veremos, as principais alterações ocorreram na Lei de Registros Públicos - Lei $\mathrm{n}^{\circ}$ 6.015/73 (a legitimação de posse será ato passível de registro, conforme dispõe o art. 167, I, 41; e o auto de demarcação urbanística será ato passível de averbação, conforme prevê o art. 167, II, 26) e também no Estatuto da Cidade - Lei n ${ }^{\circ}$ 10.257/2001.

\subsection{O REGISTRO DA POSSE NO ÂMBITO DA REGULARIZAÇÃO FUNDIÁRIA DE INTERESSE SOCIAL}

Se partirmos do tradicional ponto de vista dos preceitos do Direito Civil e da Lei de Registros Públicos, a conclusão será peremptória - a posse não é passível de ingresso no fólio real, por consistir em situação de fato. Na matrícula do imóvel ingressam os direitos reais e dados informativos sobre tais direitos.

Tanto assim que uma escritura pública, lavrada nas notas de um Tabelionato, de cessão de direitos possessórios $^{479}$, muito comum na vida cotidiana, não é passível de registro, mesmo que se mencione expressamente o respectivo número da matrícula do imóvel.

\footnotetext{
${ }^{479}$ Nas palavras de Balbino, "não encontram abrigo no registro de imóveis, mas são plenamente hábeis para a inclusão da posse dois antecessores na dos sucessores". Nicolau Balbino Filho. Registro de Imóveis Doutrina, Prática e Jurisprudência, p. 541.
} 
Assim, pela via tradicional, assevera Balbino Filho: “os imóveis possuídos sem título não têm situação de ingresso no serviço registral imobiliário. Seus possuidores terão de aguardar o decurso do tempo para, com a sentença de usucapião, gozarem dos efeitos do registro" 480 .

Por outro lado, percebemos que se opera uma mudança significativa nas visões tradicionais sobre a posse e também sobre o registro imobiliário, com o advento de nova legislação federal a regular a matéria. A Lei $\mathrm{n}^{\mathrm{0}}$ 11.977, de 2009, surge como instituidora da possibilidade do fenômeno da legitimação da posse, que será passível de ingresso no fólio real, nos termos de seu artigo 60 .

Na mesma linha, prega Loureiro que "o instituto da legitimação da posse está previsto na Lei n. 11.977 de 2009, e constitui exceção à regra de que a posse não é objeto de registro por não se tratar de um direito real, embora constitua uma relação de fato e também um direito patrimonial" 481 .

A Lei $n^{0} 11.977 / 2009$ estabelece os passos serem seguidos pelos entes estatais e particulares da sociedade civil na busca pela promoção da regularização fundiária de interesse social, visando à regularização e à concessão de novos títulos aos ocupantes de lotes irregulares, inserindo-os na economia formal e melhorando as condições de vida e de habitabilidade dos cidadãos de baixa renda.

A previsão expressa dos novos institutos consta do artigo 46 da lei: a regularização fundiária consiste no conjunto de medidas jurídicas, urbanísticas, ambientais e sociais que visam à regularização de assentamento irregulares e à titulação de seus ocupantes, de modo a garantir o direito social à moradia, o pleno desenvolvimento das funções sociais da propriedade urbana e o direito ao meio ambiente ecologicamente equilibrado.

\footnotetext{
${ }^{480}$ Nicolau Balbino Filho. Registro de Imóveis - Doutrina, Prática e Jurisprudência, p 541.

${ }^{481}$ Luiz Guilherme Loureiro. Registros Públicos - Teoria e Prática, p. 488.
} 
A aquisição da titularidade de domínio ocorrerá então por força de usucapião, também conhecida por usucapião especial urbana, conforme estabelecido no artigo 183 da Constituição Federal:

Art. 183. Aquele que possuir como sua área urbana de até duzentos e cinquenta metros quadrados, por cinco anos, ininterruptamente, e sem oposição, utilizando-a para sua moradia ou de sua família, adquirir-lhe-á o domínio, desde que não seja proprietário de outro imóvel urbano ou rural.

Apesar de não indicado no referido dispositivo constitucional, a usucapião será reconhecida somente pela via administrativa (no Cartório de Registro de Imóveis), desprovida de sentença judicial que outorgue o domínio. Como não há sentença judicial, também não se encontrarão os efeitos da coisa julgada. Voltaremos à questão da usucapião e seu prazo a seguir.

A questão da regularização fundiária não é nova e vem sendo discutida, há pelo menos quatorze anos, desde o ano 2000, pois já era a mesma matéria objeto do então conhecido Projeto de Lei $\mathrm{n}^{\mathrm{o}} 3.057 / 2000$, em trâmite no Congresso Nacional, que tinha um escopo bastante amplo e ambicioso: implementar a nova lei de parcelamento do solo urbano brasileira, substituindo a tradicional Lei $\mathrm{n}^{\mathrm{0}} 6.766 / 79^{482}$.

Este Projeto de Lei apresentava aspectos controvertidos, mesmo para os dias de hoje, como a questão dos denominados condomínios "fechados", abrangendo temas como os requisitos urbanísticos e ambientais do parcelamento do solo urbano; as responsabilidades do empreendedor e do Poder Público na implantação e manutenção do parcelamento do solo; os requisitos e critérios sobre o conteúdo e para fins de aprovação do projeto do parcelamento do solo; as competências do Município e do Estado sobre licenciamento para parcelamento do solo; as exigências para a adoção da licença urbanística e ambiental integrada, bem como para a entrega das obras e da licença final integrada; critérios para o

\footnotetext{
482 Projeto de Lei $\mathrm{n}^{\circ} 3.057 / 2000$, que tem como objetivo estabelecer as normas gerais disciplinadoras de parcelamento do solo urbano e de regularização fundiária sustentável de áreas urbanas, visando ter como denominação lei de responsabilidade territorial.
} 
registro do parcelamento do solo; e regras para os contratos, relações de consumo e direito do consumidor em parcelamento do solo.

Além de todos os pontos acima citados, de forma bastante coerente sugeria a implantação de procedimento para regularização de loteamentos irregulares no seu Título III, a Regularização Fundiária Sustentável em Áreas Urbanas, incluindo a disciplina da regularização fundiária em área urbana; regularização fundiária de interesse social e de interesse específico; demarcação urbanística e legitimação de posse; e registro da regularização fundiária de interesse social.

Como não se chegou a um consenso sobre os chamados condomínios "fechados" que seriam igualmente disciplinados pelo Projeto de Lei, tal projeto não prosperou. Todavia, todo o capítulo relativo à regularização urbanística veio a abandonar o Projeto de Lei original (com relação ao qual tinha identidade material de fato), e foi reaproveitado mediante o expediente chamado "pegar carona", para usar a expressão corrente, na legislação que estava sendo preparada em 2009 para reordenar os canais de investimento público em habitações populares, criando regras mais flexíveis de concessão de crédito, programa este batizado de "Minha Casa Minha Vida".

Encontramos, inclusive, opiniões no sentido que a Lei $\mathrm{n}^{0} 11.977 / 2009$, tal como promulgada, afronta as disposições da Lei Complementar $n^{\circ} 95$ de 26 de fevereiro de 1998, que dispõe sobre as normas para redação, edição e consolidação das leis (e por isso também conhecida como "lei das leis").

Nesse sentido é a opinião de Renato Guilherme Góes, baseada na redação do artigo $7^{\circ}$ da citada Lei Complementar $n^{0} 95$, estabelecendo que (I) excetuadas as codificações, cada lei tratará de um único objeto; (II) a lei não conterá matéria estranha a seu objeto ou a este não vinculada por afinidade, pertinência ou conexão, indicando referido autor que a Lei $\mathrm{n}^{\mathrm{o}}$ 11.977/2009 apresenta capítulos com matérias claramente distintas entre si (i.e., programa Minha Casa Minha Vida; Registro Eletrônico e custas e emolumentos cartorários; e 
Regularização Fundiária de Assentamentos Urbanos): “esses assuntos não estão vinculados por afinidade, pertinência ou conexão" ${ }^{483}$.

E, de fato, não podemos esquecer de que toda essa matéria era originalmente objeto do aludido Projeto de Lei $\mathrm{n}^{\mathrm{o}} 3.057 / 2000$, que, como visto, intentava substituir a Lei de Parcelamento do Solo Urbano (Lei ${ }^{\circ}{ }^{6.766 / 79}$ ).

Na Exposição de Motivos datada de 24 de março de 2009, que acompanhou a Medida Provisória ${ }^{\mathrm{o}} 459$ de 2009 (posteriormente convertida na Lei $\left.\mathrm{n}^{\mathrm{o}} 11.977 / 2009\right)^{484}$, afirma-se que a regularização fundiária urbana consiste em passo fundamental para a garantia do direito constitucional de moradia, especialmente para as populações de menor renda, significando o resgate da cidadania para tais populações e a sua integração à cidade formatada de acordo com os preceitos legais vigentes, além de incumbir o Poder Público de realizar investimentos nas áreas precárias, instalando serviços urbanos e infraestrutura. Indica, ainda, que faltava a edição de um marco regulatório específico para a questão da regularização fundiária urbana, com um arcabouço legal para tornar mais efetivo e célere o rito da regularização fundiária urbana.

Foi confiado aos municípios o papel preponderante para regulamentar, por meio de lei, o procedimento de regularização fundiária em seu território, como parte integrante da política urbana de inclusão social e instituindo os instrumentos de demarcação urbanística e legitimação da posse, para dar efetividade aos direitos constituídos no artigo 183 da Constituição Federal.

O escopo da Lei $n^{0}$ 11.977/2009 foi o de enfrentar e dar solução a dois tipos de irregularidades de natureza fundiária normalmente encontradas: (a) a irregularidade dominial, em que o possuidor ocupa a área pública ou privada, desprovido de qualquer título; e (b) os parcelamentos irregulares (ou irregularidade urbanística), nos quais o

\footnotetext{
${ }^{483}$ Renato Guilherme Góes. Perspectivas da Regularização Fundiária. Regularização Fundiária Urbana: Polêmicas e Controvérsias, p. 267.

484 < www.planalto.gov.br/ccivil_03/_Ato2007-2010/2009/Exm/EMI-33-MF-MJ-MP-MMA-Mcidades-09Mpv-459.htm > acessado em 17.11.2013.
} 
parcelamento de fato ocorrido não foi objeto de licenciamento e não está em conformidade com a legislação de parcelamento do solo urbano ${ }^{485}$.

Nesse sentido, toda e qualquer camada populacional, independentemente da faixa de renda, poderia se beneficiar dos novos institutos legais, mas certo é que a população de mais baixa renda está mais exposta à precariedade, irregularidade e ausência de titularidade legal, no tocante à moradia. Por essa razão a lei também vem estabelecer, nos casos de assentamentos de população de baixa renda, medidas sociais que deverão ser implantadas, para acelerar a sua inserção na cidade regular.

Com a edição da Lei $\mathrm{n}^{\mathrm{o}}$ 12.424, de 16 de junho de 2011, originada também de conversão de Medida Provisória (MP $\mathrm{n}^{\mathrm{o}} 514$, de 2010), buscou-se disciplinar e ampliar o âmbito de aplicação da Lei original $n^{0} 11.977 / 2009$. Em conformidade com a respectiva Exposição de Motivos datada de 29 de novembro de $2010^{486}$, as principais alterações foram no sentido de (a) esclarecer conceitos definidos (art. 47); (b) indicar a legitimidade para a promoção de ações de regularização fundiária (art. 50); (c) indicar a competência estadual no licenciamento ambiental da regularização fundiária de interesse social (art. 54); (d) indicar o limite da aplicação da Lei $n^{0}$ 6.766, de 1979, em face da Lei n ${ }^{0} 11.977$, de 2009 (art. 65); bem como (e) aperfeiçoar e detalhar os procedimentos para a aplicação dos instrumentos da demarcação urbanística e legitimação de posse (arts. 56, 57, 58, 60 e 60-A), além de inserir todo um capítulo novo na Lei de Registros Púbicos contendo orientações procedimentais aos oficiais registradores para efetivação dos registros e averbações relacionados à regularização fundiária (arts. 288-A a 288-G, do Capítulo XII, denominado "Registro da Regularização Fundiária”, da Lei no 6.015/79).

Assim, no ensinamento do Desembargador José Renato Nalini, por regularização fundiária se entende o "processo que inclui medidas jurídicas, urbanísticas, ambientais e sociais com a finalidade de integrar assentamentos irregulares ao contexto legal das cidades" ${ }^{487}$. Podem promover a regularização urbanísticas todos os níveis do Poder Executivo e também os

\footnotetext{
485 Brasil. Ministério das Cidades. Regularização Fundiária Urbana: como aplicar a Lei Federal n. 11.977/2009, Secretaria Nacional de Habitação e Secretaria Nacional de Programas Urbanos. p. 11.

486 Disponível em: < www.planalto.gov.br/ccivil_03/_Ato2007-2010/2010/Exm/EMi-8-MCIDADES-MFMP-MJ-MPv514- 10.htm > acessado em: 17.11.2013.

${ }^{487}$ José Renato Nalini. Perspectivas da Regularização Fundiária. Regularização Fundiária, p. 3.
} 
integrantes da sociedade civil, como os próprios interessados e as associações, cooperativas, entre outros.

No Acórdão proferido nos autos da Apelação Civil nº 0003529-65.2011.8.26.0576, em julgamento datado de 22 de março de $2012^{488}$, os desembargadores decidiram por unanimidade dar prosseguimento ao registro de uma demarcação urbanística na cidade de São José do Rio Preto, seguindo o voto proferido pelo Corregedor-Geral da Justiça e Relator José Renato Nalini, acordando que a Lei no 11.977/2011 estabeleceu "nova ordem jurídica no campo da regularização fundiária”.

Ainda nos termos do Acórdão, a referida lei "trouxe nova realidade também para a questão da regularização fundiária urbana, objetivando remover os obstáculos existentes na legislação e disposições em vigor, que vinham se mostrando insuficientes para cuidar desse problema de amplitude nacional. Diversos foram os mecanismos introduzidos no ordenamento jurídico para simplificar, conferir maior celeridade e segurança às regularizações fundiárias, que passaram a gerar efeitos desde logo, haja vista que a Lei $n^{\circ}$ 11.977/11 entrou em vigor na data de sua aplicação (art. 83), afastando, para as regularizações fundiárias de que cuida, a incidência das disposições legais e normativas vigentes com eles incompatíveis. Estabeleceu-se destarte, uma nova ordem jurídica no campo da regularização fundiária urbana (...)”.

Foram criadas pela Lei $\mathrm{n}^{0} 11.977 / 2009$ três modalidades distintas de regularização fundiária, que se somam à quarta modalidade já previamente criada pela Lei $\mathrm{n}^{\mathrm{o}}$ 11.481/2007:

(a) regularização fundiária de interesse social, tratada nos artigos 53 a 60-A, objetivando a regularização de imóveis urbanos (públicos ou privados) ocupados para moradia da população de baixa renda, de forma consolidada e irreversível (assentamentos informais consolidados), ou seja, seria apenas aplicável às áreas ocupadas pela população

\footnotetext{
${ }^{488}$ Apelação Civil no 0003529-65.2011.8.26.0576, publicada no D.J.E de 6 de junho de.2012, apresentando a seguinte ementa: "REGISTRO DE IMÓVEIS - complementação do título após sua prenotação impossibilidade - dúvida prejudicada - Lei no 11.977/11 - nova ordem jurídica no campo da regularização fundiária - incidência mesmo quando os ocupantes são titulares de domínio de fração ideal - recurso não conhecido.
} 
de baixa renda. Para que ocorra este tipo de regularização, a legislação do zoneamento do município deverá indicar previamente quais são as respectivas zonas especiais de interesse social $^{489}$ (ZEIS), pois apenas áreas localizadas em tais zonas serão passíveis de ser objeto da demarcação urbanística. Adicionalmente, áreas de propriedade da União, dos Estados e dos Municípios, se declaradas de interesse para implantação de regularização fundiária de interesse social, poderão também ser objeto da demarcação.

Assim, as zonas especiais de interesse social são aquelas identificadas pelo Poder Público como alvo para regularização, de forma que são predestinadas a receber regras urbanísticas de exceção, mais simples e menos rigorosas que aquelas previstas na legislação vigente e especialmente na Lei $n^{\circ} 6766 / 79$ para o restante da cidade, com o escopo de possibilitar certa regularização que de outra forma não seria possível, buscando privilegiar o direito à moradia para a população de baixa renda constitucionalmente previsto. O primeiro passo, então, a ser dado para iniciar o processo de regularização será indicar no zoneamento do município as áreas que serão passiveis de tal procedimento, ou seja, quais e onde estarão localizadas as ZEIS $^{490}$.

Como já mencionado, uma área de propriedade do Poder Público poderá também ser declarada de interesse para implantação de projetos de regularização fundiária de interesse social, no caso de áreas da União, dos Estados ou dos Municípios.

É a partir da especificação da ZEIS na lei de zoneamento que estará pavimentada a possibilidade de criação de regramento especifico de parcelamento (mais flexível e de caráter excepcional), para aplicação somente naquele caso concreto. Ou, dito de outra forma, se o assentamento irregular mostra-se inviável de adaptação e observância da lei urbanística vigente, cria-se uma lei específica que se adapta à realidade.

\footnotetext{
${ }^{489}$ Estatuto da Cidade (Lei n ${ }^{\circ}$ 10.257/2001): Art. 4ํㅡㄹ Para os fins desta Lei, serão utilizados, entre outros instrumentos: (...); V - institutos jurídicos e políticos: (...) (f) instituição de zonas especiais de interesse social (...).

${ }^{490}$ Como forma de incentivar os municípios a determinarem suas zonas especiais de interesse social, o Estatuto da Cidade determina que, em caso de ampliação do perímetro urbano, tais zonas devem necessariamente ser determinadas: art. 42-B. Os Municípios que pretendam ampliar o seu perímetro urbano após a data de publicação desta Lei deverão elaborar projeto específico que contenha, no mínimo: (...) (V) previsão de áreas para habitação de interesse social por meio da demarcação de zonas especiais de interesse social e de outros instrumentos de política urbana, quando o uso habitacional for permitido (...).
} 
É o que prevê o artigo 54 da aludida Lei ${ }^{0}$ 11.977/2009: no projeto de regularização fundiária de interesse social deverá constar as características da ocupação e da área ocupada para definir parâmetros urbanísticos e ambientais específicos, além de identificar os lotes, as vias de circulação e as áreas destinadas a uso público.

(b) regularização fundiária de interesse específico, tratada nos artigos 61 e 62, buscando a regularização de parcelamentos irregulares surgidos na vigência da Lei $n^{0}$ 6.766/79 (Lei de Parcelamento do Solo Urbano); consiste, por exclusão, em modalidade que não reflete os requisitos da regularização de interesse social, devendo, em princípio, ser observada a legislação urbanística vigente. Ou seja, aplicável a assentamentos irregulares não identificados como de interesse social, não sendo possível invocar as condições excepcionais e favorecidas indicadas para a regularização fundiária de interesse social.

Nesse sentido, será necessária a elaboração do projeto de regularização, também na forma do artigo 51 da lei, sujeito à aprovação pelos órgãos competentes e obtenção das licenças urbanísticas e ambientais.

(c) regularização fundiária para loteamentos anteriores à edição da Lei $\mathbf{n}^{\mathbf{0}} \mathbf{6 . 7 6 6 / 7 9}$, buscando regularizar loteamentos informais implantados antes de 19 de dezembro de 1979 (conforme disposto no art. 71 da Lei $\mathrm{n}^{0} 11.977 / 2009$ ).

(d) regularização fundiária de interesse social nos termos da Lei $\mathbf{n}^{0}$ 11.481/2007, relativa a imóveis públicos (da União, dos Estados ou dos Municípios), como forma de garantir o direito à moradia da população de baixa renda, por meio de concessão de uso especial para fins de moradia.

\subsection{PROCEDIMENTO DA REGULARIZAÇÃO: DEMARCAÇÃO URBANÍSTICA}

Nos termos da Lei $\mathrm{n}^{\mathrm{o}}$ 11.977/2009, foram destacadas três fases para a regularização de fundiária de assentamentos urbanos de interesse social.

(a) Primeira Fase: a elaboração pelo Poder Público do auto de demarcação urbanística. 
A própria lei estabelece em seu artigo 47, inciso IV, a definição para este novo instrumento, consistente no procedimento administrativo pelo qual o Poder Público, no âmbito da regularização fundiária de interesse social, demarca imóvel de domínio público ou privado, definindo seus limites, sua área, sua localização e seus confrontantes, com a finalidade de identificar seus ocupantes e qualificar a natureza e o tempo das respectivas posses.

O auto de demarcação será composto dos documentos indicados no parágrafo primeiro do artigo 56 da Lei $n^{0} 11.977 / 2009$, com redação dada pela Lei $n^{0} 12.424 / 2011^{491}$, quais sejam:

(i) planta e memorial descritivo da área a ser regularizada, nos quais constem suas medidas perimetrais, sua área total, seus confrontantes, as coordenadas preferencialmente georreferenciadas dos vértices definidores de seus limites, o número das matrículas ou transcrições atingidas e a indicação dos proprietários identificados;

(ii) planta de sobreposição do imóvel demarcado com a situação da área constante do registro de imóveis; e

(iii) certidão da matrícula ou transcrição da área a ser regularizada, emitida pelo registro de imóveis, ou, diante de sua inexistência, das circunscrições imobiliárias anteriormente competentes, quando possível.

Uma vez concluído o auto, o Poder Público deverá requerer sua averbação junto ao Cartório de Registro de Imóveis, na matrícula do imóvel objetivado. Ato contínuo, o oficial registrador procederá às buscas para identificação do proprietário da área a ser regularizada e de matrículas ou transcrições que a tenham por objeto. O proprietário deverá ser notificado; caso não seja encontrado, será convocado por edital, no prazo máximo de sessenta dias.

${ }^{491}$ Que por sua vez é resultante da conversão da Medida Provisória n ${ }^{\circ}$ 514/2010. 
Decorrido o prazo, sem impugnação, a demarcação urbanística deverá ser averbada na matrícula da área a ser regularizada.

Pode o proprietário apresentar impugnação, no prazo de 15 dias. Se isso ocorrer, o Poder Público deverá se manifestar em sessenta dias (se a impugnação for parcial, o procedimento deverá continuar com a área não afetada), no sentido de mudar o auto ou buscar outra medida para afastar a impugnação do proprietário.

Desta forma, percebe-se ser legitimado o Poder Público a adotar medidas que entender necessárias para afastar a oposição manifestada pelo proprietário e até mesmo para retificar o auto.

Não apresentando sucesso esta atuação pelo Poder Público, o registrador imobiliário deverá promover tentativa de acordo entre as partes. Não havendo ou não sendo possível o acordo, a impugnação será encerrada com relação à área impugnada, e o auto será devolvido ao Poder Público. Nesse caso, restará aos interessados recorrer às vias ordinárias de jurisdição, ingressando com a ação de usucapião ou outras adequadas, conforme o caso.

Após a averbação do auto de demarcação, o Poder Público apresentará o projeto de parcelamento de solo aplicável, com lotes, acarretando o registro deste parcelamento de solo. A Lei $n^{0}$ 12.424/2011 veio a determinar, mediante a inclusão do art. 288-A na Lei de Registros Públicos, a necessidade de abertura de nova matrícula para o auto de demarcação.

Evidentemente, caso existam ônus reais recaindo sobre o imóvel objeto da demarcação, devem ser transportados para a nova matrícula, em atendimento ao princípio da continuidade dos atos registrais. Todavia, a lei não indica ou apresenta solução prática para o destino de tais ônus.

(b) Segunda Fase: a situação possessória e sua legitimação.

Uma vez registrado o referido auto de demarcação, passará o Poder Público a cuidar e elaborar o parcelamento de solo específico incidente sobre a área, indicando também a 
abertura de vias, realocação de moradias, obra de infraestrutura, equipamentos urbanos. Este parcelamento do solo, por força do artigo 58 da Lei $n^{0} 11.977 / 2009$, deverá ser encaminhado também a registro na matrícula da demarcação.

A terceira fase será a conversão da posse em propriedade, como veremos nos parágrafos seguintes.

\subsection{O TÍTULO DE LEGITIMAÇÃO DE POSSE}

A partir do registro do parcelamento do solo, poderão ser criadas e abertas novas matrículas para cada um dos lotes resultantes do parcelamento.

Assim, ato contínuo, o Poder Público concederá o título de legitimação de posse aos ocupantes $^{492}$, preferencialmente tendo como beneficiária a mulher, que serão levados a registro nas respectivas matrículas criadas para os lotes.

Legitimação de posse "é a certidão de reconhecimento do órgão público da posse particular, um poder excepcional dado ao Poder Executivo da entidade federativa (...) pela Lei $\mathrm{n}^{\mathrm{o}} 11.977$, e, mais o poder de qualificá-la quanto à identidade do possuir, apurar o seu tempo de existência e aferir a sua natureza" ${ }^{\text {"493 }}$. Pode também assumir a forma de contrato, celebrado entre o Poder Público e o possuidor interessado.

O Poder Público deverá realizar o cadastramento dos possuidores, no âmbito do processo de regularização, conforme estabelecido no artigo 59, parágrafo único, da referida lei.

Deve-se destacar importante alteração no artigo 59 da Lei 11.977/2009 introduzida pela Lei 12.424/2011, correspondente à revogação do seu inciso terceiro, que contava com a seguinte redação:

Art. 59. A legitimação de posse devidamente registrada constitui direito em

\footnotetext{
${ }^{492}$ Não podem ser concessionários, foreiros ou proprietários de outros imóveis urbanos ou rurais, ou ainda deter legitimação de posse anterior.

${ }^{493}$ Arthur Rios. Regularização Fundiária Urbana, p. 95.
} 
favor do detentor da posse direta para fins de moradia.

Parágrafo único. A legitimação de posse será concedida aos moradores cadastrados pelo poder público, desde que:

I - não sejam concessionários, foreiros ou proprietários de outro imóvel urbano ou rural;

II - não sejam beneficiários de legitimação de posse concedida anteriormente;

e

III - os lotes ou fração ideal não sejam superiores a $250 \mathrm{~m}^{2}$ (duzentos e cinquenta metros quadrados).

Passando, após a edição da Lei $n^{\circ}$ 12.424/2011 a constar com a seguinte redação:

Art. 59. A legitimação de posse devidamente registrada constitui direito em favor do detentor da posse direta para fins de moradia.

$\S 1^{\circ}$ A legitimação de posse será concedida aos moradores cadastrados pelo poder público, desde que:

I - não sejam concessionários, foreiros ou proprietários de outro imóvel urbano ou rural;

II - não sejam beneficiários de legitimação de posse concedida anteriormente.

III - (revogado).

Buscou-se, com a revogação em tela, o entendimento que seria possível abranger como passível de usucapião áreas superiores a duzentos e cinquenta metros quadrados, resultando na titulação de possuidores de imóveis com maior extensão. Nesse mesmo sentido, a Lei 12.424/2011 introduziu o seguinte dispositivo: “Art. 60, $\S 3^{\circ}$. No caso de área urbana de mais de $250 \mathrm{~m}^{2}$ (duzentos e cinquenta metros quadrados), o prazo para requerimento da conversão do título de legitimação de posse em propriedade será o estabelecido na legislação pertinente sobre usucapião". 
Todavia, tais dispositivos da Lei 12.424/2011 devem ser entendidos como inconstitucionais por infringir determinação expressa do artigo 183 da Constituição Federal, que possibilitou a usucapião especial urbana apenas em imóveis com até duzentos e cinquenta metros quadrados, não sendo possível à legislação infraconstitucional ampliar os parâmetros e limites constitucionalmente fixados, exceto se houver emenda à Constituição que trate e altere o tema.

Citam ainda o professor Maluf e Adriana Caldas do Rego Freitas Dabus Maluf que a usucapião especial de imóvel urbano consiste no "instrumento urbanístico de status constitucional, previsto no art. 183 da Constituição Federal, cujos objetivos são a regularização fundiária que assegura o direito a moradia aos segmentos sociais menos favorecidos e o cumprimento da função social da propriedade" ${ }^{\star 494}$. Indicam os autores que o Estatuto da Cidade, em sua seção V, prevê a usucapião especial de imóvel urbano, como um dos instrumentos da política urbana, bem como a usucapião especial coletiva de imóvel urbano:

\section{Seção V}

Da usucapião especial de imóvel urbano

Art. $9^{\circ}$ Aquele que possuir como sua área ou edificação urbana de até duzentos e cinquenta metros quadrados, por cinco anos, ininterruptamente e sem oposição, utilizando-a para sua moradia ou de sua família, adquirir-lhe-á o domínio, desde que não seja proprietário de outro imóvel urbano ou rural.

(...)

Art. 10. As áreas urbanas com mais de duzentos e cinquenta metros quadrados, ocupadas por população de baixa renda para sua moradia, por cinco anos, ininterruptamente e sem oposição, onde não for possível identificar os terrenos ocupados por cada possuidor, são susceptíveis de serem usucapidas coletivamente, desde que os possuidores não sejam proprietários de outro imóvel urbano ou rural ${ }^{495}$.

\footnotetext{
${ }^{494}$ Carlos Alberto Dabus Maluf, Adriana Caldas do Rego Freitas Dabus Maluf. Comentários ao Estatuto da Cidade (Lei $\mathbf{n}^{\mathbf{0}} \mathbf{1 0 . 2 5 7 / 2 0 0 1 ) , ~ p . ~} 54$.

${ }^{495}$ Tecem críticas referidos autores à forma dada à usucapião coletiva, especialmente pela ausência de formas concretas de sua implantação; da criação de um condomínio com grande potencial de surgimento de problemas, e o potencial incentivo à criação e proliferação de favelas, que não consistem na melhor forma de
} 
Não poderia deixar de ser esse o entendimento, até mesmo porque, vigorando a possibilidade de a usucapião especial urbana atingir também imóveis com área superior a duzentos e cinquenta metros quadrados, conforme a atual redação da Lei 11.977/2009, tal como alterada pela Lei $\mathrm{n}^{\mathrm{o}} 12.424 / 2011$, significaria que a usucapião de imóveis com metragem superior aos 250 metros quadrados seria igualmente subtraída da apreciação judicial, esvaziando e enfraquecendo ainda mais a ação (judicial, para restar claro) de usucapião, que deveria observar a via judicial ordinária mediante a aplicação, observação e constatação dos requisitos dos artigos 1.238 (usucapião extraordinário) e 1.242 (usucapião ordinário) do Código Civil pelo juiz.

Em outras palavras, estar-se-ia expandindo o âmbito de atuação da usucapião administrativa, ao arrepio do artigo 183 da Constituição Federal, abrangendo e abolindo de forma incorreta procedimentos judiciais baseados nos citados artigos 1.238 e 1.242 do Código Civil.

Deve-se ressaltar que os artigos 1.240 do Código Civil e $9^{\circ}$ do Estatuto da Cidade, que tratam da mesma hipótese da usucapião especial urbana mantiveram a metragem de até duzentos e cinquenta metros quadrados, estando, portanto, o desacordo com o texto constitucional apenas nos referidos artigos 59, parágrafo $1^{\circ}$, III, e 60, parágrafo $3^{\circ}$, da Lei 11.977/2009.

Pela legitimação da posse, o Poder Público reconhecerá a situação de fato da posse existente, desde que mansa e pacífica, para a qual haverá a necessária publicidade e efeito de validade erga omnes, pois esta posse será passível de registro no Cartório de Registro de Imóveis.

Esta é a primeira vez no Direito brasileiro que a posse recebeu acesso de forma tão abrangente, ao fólio real no direito pátrio, aspecto revolucionário, que de imediato altera a

estabelecimento de moradias humanas, pelos conhecidos problemas a elas associados: "na realidade vemos que, no afã de resolver o problema habitacional, permitiu o Estatuto da Cidade, através da aplicação do art. $10^{\circ}$, a ocupação irregular, conferindo a possibilidade de haver a instalação da população carente em formas habitacionais de favelas, que longe está sedimentada, em nossa concepção, da forma mais adequada, mais humana de habitação". Carlos Alberto Dabus Maluf, Adriana Caldas do Rego Freitas Dabus Maluf. Comentários ao Estatuto da Cidade (Lei n⿳0 10.257/2001), p. 92. 
concepção meramente factual desse instituto, podendo considerá-lo como verdadeiro direito real.

Além disso, o título de legitimação de posse também está previsto no Estatuto da Cidade como um dos instrumentos em geral da Política Urbana, tal como identificada a Lei $\mathrm{n}^{\mathrm{o}}$ 10.257/2001. Podem, portanto, ser entendidas como duas situações distintas, a posse registrável por força do Estatuto da Cidade e a posse que ingressa no Registro Imobiliário por força da Lei 11.977/2009:

\section{CAPÍTULO II}

\section{DOS INSTRUMENTOS DA POLÍTICA URBANA}

\section{Seção I}

Dos instrumentos em geral

Art. $4^{\circ}$ Para os fins desta Lei, serão utilizados, entre outros instrumentos:

(...)

$\mathrm{V}$ - institutos jurídicos e políticos:

\section{$(\ldots)$}

(u) legitimação de posse.

Nesse sentido, ensinam também o professor Maluf e Adriana Caldas do Rego Freitas Dabus Maluf, ponderando que a regularização fundiária e legitimação da posse foram incluídos como institutos jurídicos e políticos (contidos no inciso $\mathrm{V}$ do art. $4^{\mathrm{o}}$ ), dentro dos instrumentos mencionados no artigo $4^{\circ}$ do Estatuto da Cidade, que podem ser acessados para implantação e desenvolvimento da política urbana, fixando assim "as linhas mestras para a política urbana, bem como o seu conteúdo, instituindo os elementos basilares para em executando a política urbana e forma planejada, garantir aos cidadãos a fruição do direito às cidades sustentáveis" ${ }^{496}$.

Tanto assim que o novo artigo da Lei de Registros Públicos, ao mencionar o registro da legitimação da posse, de igual forma não faz menção a nenhum de tais diplomas, quer à Lei $\mathrm{n}^{\mathrm{o}} 11.9877 / 2009$, quer ao Estatuto da Cidade, abrangendo, portanto, ambos.

\footnotetext{
${ }^{496}$ Carlos Alberto Dabus Maluf, Adriana Caldas do Rego Freitas Dabus Maluf. Comentários ao Estatuto da Cidade (Lei n⿳0 10.257/2001), p. 36.
} 
A principal medida implementada com a edição da Lei n ${ }^{0} 11.977 / 2009$ e 12.424, de 16 de junho de 2011, talvez tenha sido as alterações que provocaram na Lei de Registros Públicos (Lei $n^{0}$ 6.015/73), com a introdução de novos instrumentos passíveis de registro (ou averbação, conforme o caso), por força ao artigo 167 daquela lei: o auto de demarcação urbanística e a legitimação de posse:

Art. 167 - No Registro de Imóveis, além da matrícula, serão feitos.

I - o registro:

(...)

41. da legitimação de posse.

II - a averbação:

(...)

26. do auto de demarcação urbanística;

27. da extinção da legitimação de posse; (...)

A própria Exposição de Motivos da Lei $\mathrm{n}^{\mathrm{o}}$ 12.424/2012 reflete que uma das intenções foi estabelecer "a nova redação proposta para o item 36, do inciso I, do art. 167 visa ampliar as possibilidades de registro da imissão provisória na posse, que pela redação em vigor restringe-se aos casos de imóveis destinados a parcelamento popular; nesse artigo, também são acrescentados os itens I, 42 e II, 27, 28 e 29, de forma a possibilitar o registro ou a averbação de outros instrumentos de regularização fundiária de assentamentos urbanos".

Por sua vez, a Corregedoria Geral de Justiça de São Paulo editou os provimentos $\mathrm{n}^{\mathrm{o}}$ 18/2012 e n ${ }^{0}$ 21/2013, nos quais também conferiu caráter mais abrangente à possibilidade de registro da demarcação urbanística e legitimação da posse, pois, em princípio, apenas a posse decorrente da regularização fundiária de interesse social poderia ser registrada. Todavia, pelo entendimento a seguir indicado, da Corregedoria Geral de Justiça de São 
Paulo, também a posse originada da regularização fundiária especial pode ser objeto de registro:

Item 242.2 No caso de área urbana de mais de $250 \mathrm{~m}^{2}$ e no de legitimação de posse decorrente de regularização fundiária de interesse especial ou de parcelamento do solo anterior a 19 de dezembro de 1979, o prazo para requerimento da conversão do título de legitimação de posse em propriedade será o estabelecido na legislação pertinente sobre usucapião. (grifo nosso)

Nesse mesmo sentido, de possibilitar maior abrangência ao escopo da lei, frisamos que o Acórdão proferido nos autos da Apelação Civil no 0003529-65.2011.8.26.0576, em julgamento datado de 22 de março de $2012^{497}$, foram estendidos ao detentor da titularidade da fração ideal de um imóvel os mesmos direitos e prerrogativas da Lei $\mathrm{n}^{\circ}$ 11.977/90 conferidos ao mero possuidor, especialmente em razão do princípio da isonomia, e também para que os interessados não tenham que "trilhar a longa e onerosa via da usucapião".

A posse poderá ser cedida, provavelmente com a obtenção da anuência do Poder Público que a legitimou, e essa cessão deverá ser também averbada na respectiva matrícula. Poderá também, em nossa visão, ser outorgada em garantia a credores, mediante a celebração do instrumento próprio, que também deverá ser registrado junto ao Cartório de Registro de Imóveis ${ }^{498}$. Desta forma, e para maior segurança dos possuidores, recomenda-se que novo ajuste legislativo seja implementado para que esta orientação fique também clara aos oficiais registradores.

Resta acrescentar que esta posse assim legitimada, atenderá finalisticamente à determinação do art. $6^{\circ}$ da Constituição Federal ${ }^{499}$, tal como alterado pela Emenda

\footnotetext{
497 Apelação Civil no 0003529-65.2011.8.26.0576, publicada no D.J.E de 6 de junho de 2012, apresentando a seguinte ementa: "REGISTRO DE IMÓVEIS - complementação do título após sua prenotação impossibilidade - dúvida prejudicada - Lei no $11.977 / 11$ - nova ordem jurídica no campo da regularização fundiária - incidência mesmo quando os ocupantes são titulares de domínio de fração ideal - recurso não conhecido.

${ }^{498}$ O Projeto de Lei original $n^{\circ} 3.057 / 2000$ previa expressamente essa hipótese: a posse registrada poderia ser dada em garantia.

${ }^{499}$ Art. $6^{\circ}$ São direitos sociais a educação, a saúde, a alimentação, o trabalho, a moradia, o lazer, a segurança, a previdência social, a proteção à maternidade e à infância, a assistência aos desamparados, na forma desta Constituição (Redação dada pela Emenda Constitucional nº 64, de 2010).
} 
Constitucional $n^{\circ} 64$ de 2010, consistindo na indicação expressa de que todos brasileiros terão direito à moradia, concretizando este direito ali incluído pela Emenda. É o que menciona o artigo 59 da Lei 11.977/2009: "a legitimação da posse devidamente registrada constitui direito em favor do detentor da posse direta para fins de moradia”. Deixa, portanto, de ser norma programática um dos direitos sociais mais relevantes (qual seja, o de moradia), para ser concretizado e materializado pelo registro da posse legitimada junto à matrícula do imóvel ${ }^{500}$.

(c) Terceira Fase: convolação da Posse em Propriedade, sendo desnecessária a sentença judicial.

Uma vez decorridos cinco anos, o título de legitimação de posse poderá ser convolado em título de propriedade, mediante requerimento, adquirida por usucapião, configurando a inédita figura da usucapião administrativa no Direito brasileiro. Na opinião de Loureiro, "não há necessidade, portanto, de ajuizamento da ação de usucapião para a declaração da propriedade". Ainda na opinião de Loureiro, embora a lei não seja clara, este procedimento seria semelhante ao do loteamento previsto na Lei $\mathrm{n}^{\mathrm{o}} 6.766$ de $1979^{501}$.

Para requerer a conversão da posse em propriedade, o adquirente deverá apresentar:

(a) certidões do cartório distribuidor demonstrando a inexistência de ações em andamento que versem sobre a posse ou a propriedade do imóvel;

(b) declaração de que não possui outro imóvel urbano ou rural;

\footnotetext{
${ }^{500}$ No tocante ao referido direito de moradia, já ensinava o Professor Rui Geraldo Camargo Viana que "na III Conferencia Habitat, um dos nossos ministros (...) arreceava-se de colocar a expressão 'direito à moradia' na Carta de Intenções daquela Conferencia. Dizia ele que essa expressão poderia levar a população a cobrar esse direito na Justiça. Durante os debates, dizia o ministro: 'Concluímos que o direito à moradia é um direito de natureza programática, ou seja, será obtido progressivamente e não pode ser cobrado na Justiça'. Ledo engano: essas não são normas programáticas apenas, são direitos essenciais. Os direitos do art. $6^{\circ}$ da Constituição não são menos importantes, menos sobranceiros que os do art. $5^{\circ}$, porque eles se completam". Continua o professor Ruy Geraldo: "Eles devem ter a mesma conotação que os direitos civis, políticos, econômicos, sociais e culturais. (...) o direito à moradia é um direito constitucional que atribui direito aos cidadãos". E conclui: “o direito civil tem que resolver o problema da moradia e suas implicações civis. A moradia é o grande problema. A propriedade é o grande direito”. Rui Geraldo Camargo Viana. Comentários sobre o Projeto do Código Civil Brasileiro, Série Cadernos do Conselho da Justiça Federal - Direito das Coisas, Vol. 20, Brasília, 2002.

${ }^{501}$ Luiz Guilherme Loureiro. Registros Públicos - Teoria e Prática, p. 490.
} 
(c) declaração de que o imóvel é utilizado para sua moradia ou de sua família; e

(d) declaração de que não teve reconhecido anteriormente o direito à usucapião de imóveis em áreas urbanas.

Em nossa visão, não somente este procedimento se assemelha ao procedimento de parcelamento de solo urbano mediante loteamento, mas sim corresponde efetivamente a um loteamento às avessas, ou de trás para frente. Ao invés de se criar um loteamento seguindo a legislação pertinente e as posturas e limites urbanísticos municipais, há o reconhecimento de fato do Poder Público diante de um loteamento irregular de que nada mais há a ser feito, admitindo a sua irreversibilidade, de forma que o Poder Público, para aquele caso fático, cria uma regra a posteriori, específica para o loteamento, e a partir daí leva a regularização em frente, apenas consolidando e trazendo à formalidade registrária uma ocupação que de outra forma nunca seria passível de regularização ${ }^{502}$.

Também seria um passo adiante e mais vantajoso do que a já existente usucapião coletiva, pois as unidades já viriam individualizadas, não sendo necessário estabelecer um condomínio voluntário, com todos os inconvenientes que este traria ${ }^{503}$.

Entendemos necessário, nesse momento, indicar algumas questões importantes, que podem ser objeto de futuros trabalhos, notadamente na Segunda Fase indicada acima, quando da elaboração, e que envolvem a própria natureza jurídica da chamada "usucapião administrativa" trazida pela Lei $n^{0} 11.977 / 2009^{504}$.

502 A crítica a esta forma de disciplinar a matéria, quando encontrada, faz menção que este é um procedimento inverso daquele determinado pela Lei $\mathrm{n}^{\circ} 6.766 / 79$ e poderia consistir em um incentivo à novas invasões e criações de novos loteamentos irregulares, mesmo por pessoas de má-fé aproveitando da falta de informação e esclarecimento da população.

${ }^{503}$ A análise de todos os inconvenientes foi feita por Nelson Kojranski, As Favelas: O Desafio de sua Regularização Jurídica. Revista do Instituto dos Advogados de São Paulo, 2004, vol. 14, p. 59.

${ }^{504}$ Mauricio Baptistella Bunazar identifica outra modalidade de usucapião familiar prevista na Lei $n^{\circ}$ 11.977/2009, alterada pela Lei $n^{\circ} 12.424 / 2011$, que também acrescentou novo artigo 1.240-A ao Código Civil. Esta nova modalidade busca resolver um problema social corriqueiro originado do fim de relação conjugal pela simples partida de um dos cônjuges, deixando o que permaneceu na mordia em situação difícil para formalizar a venda do imóvel. Com a inclusão do novo artigo, operar-se-á no prazo de apenas dois anos a prescrição aquisitiva a favor do cônjuge que permaneceu. $\mathrm{O}$ autor, assim, traça os elementos do problema: "quando a propriedade do imóvel pertence a ambos os membros do casal, o problema consiste nem regularizar a situação jurídica do membro do casal remanescente relativamente ao imóvel, pois, por ser de 
Por exemplo, se o proprietário não apresentar impugnação, por qualquer razão, quando notificado pelo oficial registrador, o auto prosseguirá, o parcelamento do solo será realizado, as matrículas abertas, e eventualmente a posse registrada e posteriormente convolada em propriedade.

Nesse sentido, para efeitos práticos, já não teria ocorrido a aquisição da titularidade pelo possuidor naquele momento, mediante a inação do proprietário, doação ou outro título de manifestação unilateral da vontade? Ou mesmo de forma indireta de desapropriação, na qual o Poder Público leva um imóvel a atingir um escopo social de moradia, sem, no entanto, arcar com qualquer indenização? Claro que, ao interpor impugnação, o procedimento não prosseguirá, mas tal fato não invalida o outro: que em caso de inexistência de impugnação, a titularidade de domínio já não se encontra com o proprietário original, pois na prática já irreversível o procedimento até a sua conclusão.

Terá a lei apenas indicado a necessidade do decurso do prazo de 5 anos para caracterizar o prazo da usucapião indicada no artigo 183 da Constituição Federal e, assim, evitar o recolhimento do ITBI - Imposto sobre Transmissão de Bens Imóveis ou ITMCD - Imposto de Transmissão Causa Mortis e Doação, que incidiria na primeira hipótese? Terá valido a pena impedir o ocupante de obter o seu direito à propriedade e à moradia, tendo que esperar mais 5 anos para tanto?

São questões que somente o tempo e a prática poderão responder.

\subsection{A POSSE E O DIREITO REAL}

Mencionamos anteriormente que o principal argumento daqueles que buscam negar o aspecto real ao direito de posse baseia-se na impossibilidade de registro deste instituto na

propriedade comum, não conseguirá aliená-lo a terceiro, embora, em razão da ausência do outro condômino, tenha de suportar com exclusividade todos os gastos com sua manutenção". Assim, o artigo 1.240-A reduz drasticamente o prazo dessa usucapião familiar, ou volta à visão da Lei das XII Tábuas, que também mencionada o prazo de dois anos - para extinguir esse condomínio e levar à propriedade exclusiva do cônjuge remanescente. Mauricio Baptistella Bunazar. 10 anos de vigência do Código Civil Brasileiro de 2002 - Estudos em homenagem ao professor Carlos Alberto Dabus Maluf - Usucapião Familiar: Primeiras Impressões, p. 461. 
matrícula do imóvel, junto ao Cartório de Registro de Imóveis, uma vez que a posse não está prevista como direito real passível de acolhida no Registro Imobiliário, quer no Código Civil, quer na Lei de Registros Públicos.

Mas de qual posse estamos diante nessa modalidade de regularização fundiária? Tratar-seia de alguma posse qualificada?

O artigo 167 da Lei de Registro Públicos, tal como introduzido pela Lei $n^{\circ}$ 11.977/2009, não menciona expressamente que se trata apenas da legitimação de posse originada nos termos da aludida $\mathrm{n}^{\circ}$ Lei 11.977/2009, de forma que, da inexistência de limitação legal expressa, poder-se-ia considera para efeitos de registro outro termo de legitimação de posse, outorgado por outra entidade estatal:

Art. A Lei $\mathbf{n}^{\mathbf{0}} \mathbf{6 . 0 1 5}$, de 31 de dezembro de 1973, passa a vigorar com as seguintes alterações:

“Art. 167 (...)

$\mathrm{I}-(\ldots)$

41. da legitimação de posse.

Também o Estatuto da Cidade recebeu a inclusão expressa da legitimação da posse:

Art. 78. O inciso $\mathrm{V}$ do art. $4^{\mathrm{o}}$ da lei 10.257 de 10 de julho de 2001, passa a vigorar acrescido das seguintes alíneas $t$ e $u$ :

(...)

Art. $4^{\mathrm{o}}(\ldots)$

(u) legitimação de posse

Assim, percebe-se que os novos instrumentos da demarcação urbanística e da legitimação da posse foram criados para acelerar processos de regularização fundiária, que anteriormente só seriam resolvidos pela ação judicial de usucapião, mas na medida em que 
a posse ingressa na Lei de Registro Públicos, e mesmo no Estatuto da Cidade, torna-se título e instrumento hábil a merecer registro na matrícula do imóvel, caracterizando, no caso da posse, um direito real, oponível erga omnes e sujeito à sequela.

Apresentamos a seguir gráfico explicativo dos principais passos da regularização fundiária de interesse social, até o registro da posse e sua posterior conversão em domínio, tabularmente. 


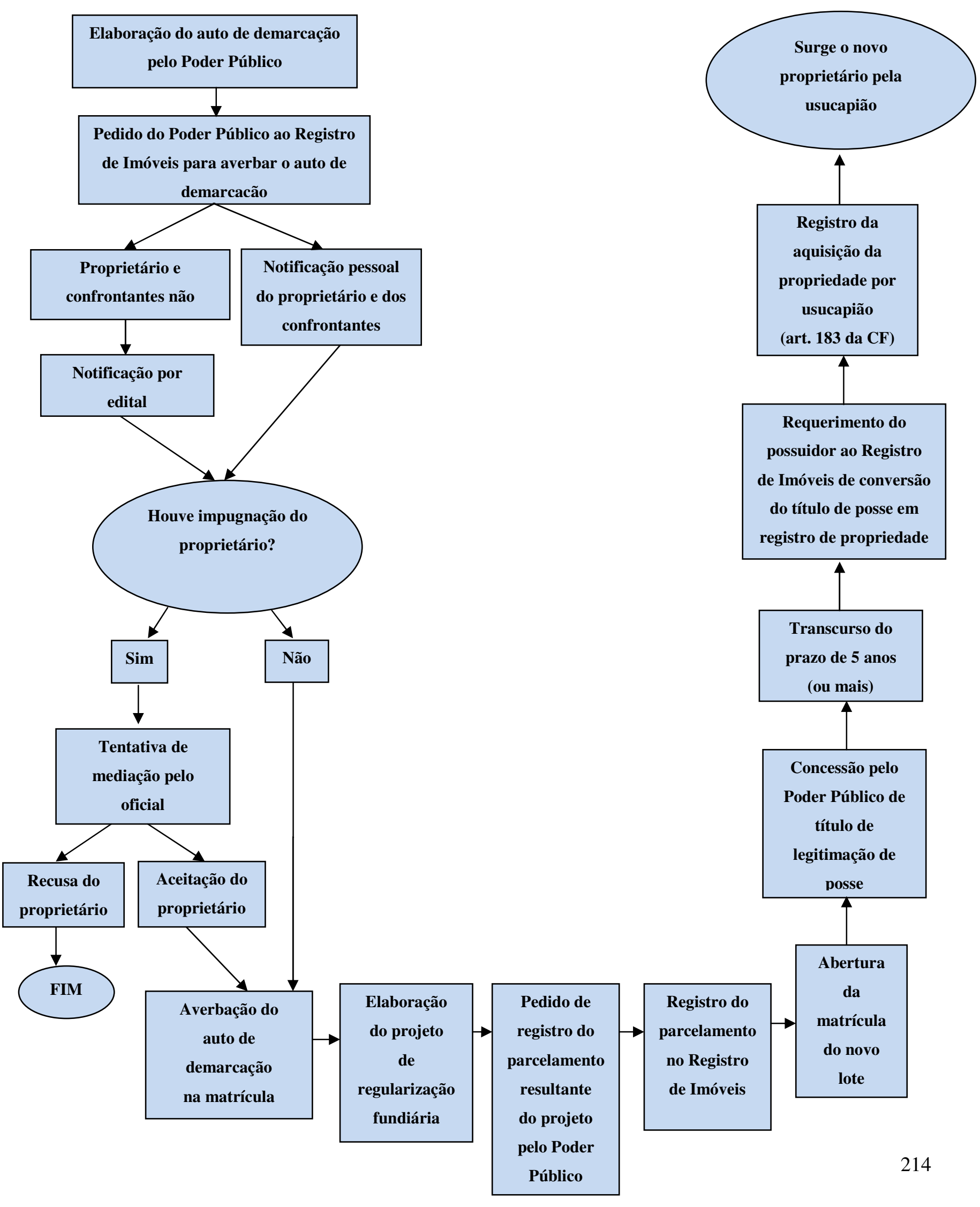




\subsection{A REGULARIZAÇÃO FUNDIÁRIA NO BRASIL - CASOS PRÁTICOS PESQUISADOS}

Buscamos o primeiro caso de regularização fundiária resultante do novo sistema legal inaugurado pela Lei $\mathrm{n}^{\circ}$ 11.977/2009 ocorrido na cidade de São Paulo, objetivando indicar seus resultados, bem como verificar como a referida lei estava sendo concretizada na vida prática.

A Prefeitura de São Paulo indica o caso do Conjunto Residencial Novo Horizonte como o primeiro a ser desenvolvido no regime estabelecido pela nova lei.

Ademais, em consultas com Oficiais Registradores e representantes do IRIB (Instituto dos Registradores Imobiliários do Brasil), encontramos também o caso mais recente da Comarca de São José dos Campos, também reconhecida pelo bem sucedido programa de regularização fundiária.

Passaremos a tratar de tais casos práticos a seguir.

\section{(a) Conjunto Residencial Novo Horizonte, na cidade de São Paulo}

Noticiado como o primeiro caso de regularização fundiária, consistiu em loteamento implantado em área de 20 mil metros quadrados, em parte das matrículas $\mathrm{n}^{\text {os }} 15.556 \mathrm{e}$ 15.558 do $18^{\circ}$ Cartório de Registro de Imóveis de São Paulo, localizado em Pirituba, na zona norte da Cidade.

Pela pesquisa realizada junto ao referido Cartório de Registro de Imóveis, e com base nas certidões de matrículas solicitadas mediante requerimento e obtidas, percebeu-se que fora de fato levado às matrículas o registro da demarcação urbanística.

Percebemos que, neste caso de Pirituba, não foi interposta qualquer oposição pelos proprietários originais, culminado, desta forma, no registro do parcelamento de solo, e 
também posterior abertura de matrículas específicas para cada um dos novos lotes regularizados (um total de 178 lotes e respectivas matrículas, de $\mathrm{n}^{\text {os }} 207.283$ a 207.461). Lembramos, por oportuno, que o procedimento para demarcação urbanística e emissão dos Termos de Legitimação de Posse na cidade de São Paulo encontram-se disciplinados pelos Decretos municipais $n^{\circ} 51.876 / 2010$ e 52.896/2012.

Desta forma, em conclusão, foi implantada a regularização deste assentamento que outrora era considerado irregular, e que agora passa a ser incluído na cidade "formal", pois cada lote é objeto de uma nova matrícula autônoma junto ao Cartório de Registro de Imóveis.

Dever-se-ia, portanto, levar à matrícula de cada lote o registro de cada posse legitimada, de forma a haver início ao prazo de 5 anos para que a posse se convole em propriedade por efeito de seu próprio registro.

Todavia, conforme a consulta formulada em nossa pesquisa perante o referido Cartório, em nenhuma das 178 matrículas havia ainda sido registrado o Termo de Legitimação de Posse por nenhum dos interessados.

Considera-se essa falta de registro da posse uma infelicidade, pois desde o registro do parcelamento já se transcorrera diversos meses, que foram desperdiçados na contagem do prazo de 5 anos para convolação da posse em propriedade.

\section{(b) Loteamentos Recanto dos Eucaliptos e Jardim Mesquita, na Cidade de São José dos Campos.}

Em nossa pesquisa realizamos também uma outra descoberta, ocorrida na comarca de São José dos Campos. Obtivemos junto à Oficial Substituta daquela circunscrição imobiliária exemplos do registro da legitimação de posse, que anexamos a seguir ao presente trabalho.

Como é possível depreender, está ilustrado claramente nas certidões das matrículas (anexas no item seguinte) todos os registros e averbações relativos à regularização fundiária de interesse público, quais sejam, a demarcação urbanística, o projeto de parcelamento, a abertura de novas matrículas para os lotes e o registro do título de posse legitimada. 
No caso do loteamento Recanto dos Eucalíptos, a posse está registrada sob Registro n 02 na matrícula $\mathrm{n}^{\circ}$ 212.901, enquanto no caso do loteamento Jardim Mesquita, a a posse está registrada sob Registro $n^{\circ} 04$ na matrícula n 200.855, ambas do $1^{\circ}$ Cartório de Registro de Imóveis de São José dos Campos.

Depreende-se que, na prática, das atividades registrarias já se está procedendo ao registro da posse legitimada.

(c) Também apresentamos um exemplo de Termo de Legitimação de Posse (incluído no item seguinte) outorgado pela Prefeitura de São José dos Campos, para ilustrar como esse importante título se materializa, anteriormente a ser levado à registro na matrícula do imóvel. 


\title{
9.6. ANEXOS - REGISTRO DA POSSE NA MATRÍCULA DO IMÓVEL
}

\author{
Registro da posse legitimada na matrícula do imóvel, \\ junto ao Cartório de Registro de Imóveis \\ (matrículas $\mathrm{n}^{\circ} \mathrm{s} 212.901$ e 200.855)
}

Termo de Legitimação de Posse

(outorgado pela Prefeitura de São José dos Campos) 


\begin{tabular}{|l|c|}
\hline Matrícula & Ficha \\
212.901 & 01 \\
\hline
\end{tabular}

LIVRO NÚMERO DOIS $1^{\circ}$ OFICLAL DE REGISTRO DE IMÓVEIS E ANEXOS SÃO JOSÉ DOS CAMPOS - SP

Em 31 de julho de 2013.

\section{REGISTRO GERAL}

Imóvel:

RECANTO DOS EUCALIPTOS

O lote de terreno, sem benfeitorias, com a área de 128,94 metros quadrados, sob $\mathrm{n}^{\circ}$ 03, da quadra $\mathrm{C}$, situado com frente para a Rua 02 , do loteamento denominado RECANTO DOS EUCALIPTOS, desta cidade, comarca e $1^{a}$ circunscrição imobiliária de São José dos Campos, com as seguintes medidas e confrontações: 15,29 metros de frente para a Rua $02 ; 8,73$ metros pelo lado direito de quem da Rua olha para o lote, com o lote $n^{\circ} 02 ; 8,18$ metros pelo lado esquerdo, com o lote $n^{\circ} 04 \mathrm{e}$ 15,22 metros nos fundos, com o lote $n^{\circ} 01$.

\section{Proprietários indicados na matrícula de origem.}

Registro Anterior: Matrícula n 208.297 em 29 de outubro de 2012, estando a Regularização Fundiária registrada sob $\mathrm{n}^{\circ} 03$, livro 2 , deste Cartório.

Protocolo $n^{\circ} 510.389$ em 05 de julho de 2013.

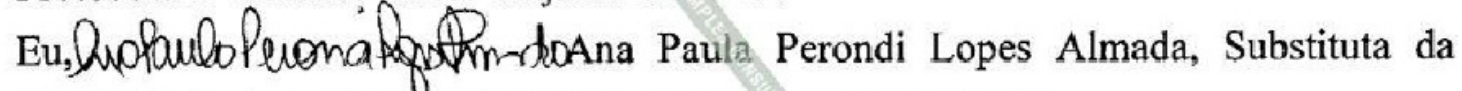
Oficial digitei, conferi dinstrumento, o ato praticado e assino.

Av. 01 - Em 31 de julho de 2013.

Regularização Fundiária

Faço a presente para constar que o imóvel objeto desta matrícula foi submetido a Regularização Fundiária de Interesse Social, nos ternos do artigo 53 e seguintes da Lei $n^{\circ} 11.977 / 2009$. Protocolo ${ }^{\circ} 510.389 \mathrm{em} 05$ de julho de 2013.

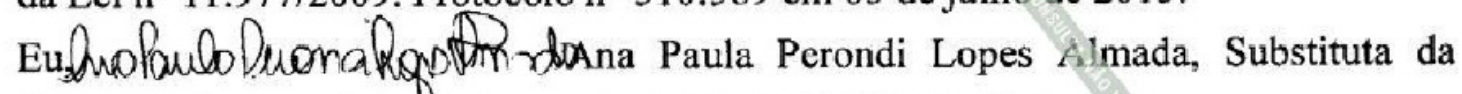
Oficial digitei, conferi o instrumento, $o$ ato praticado e assino.

R. 02 - Em 05 de dezembro de 2013.

Legitimaçăo de Posse

Por Termo de Legitimação de Posse, contrato n 29434, passado nesta cidade, em 07 de outubro de 2013, a PREFEITURA MUNICIPAL DE SÃO JOSÉ DOS CAMPOS, CNPJ $n^{\circ}$ 46.643.466/0001-06, nos termos da Lei Federal 11.977/2009, concedeu título de legitimação de posse referente ao imóvel objeto desta matrícula, para SEBASTIÃO AUGUSTO DE ANDRADE, brasileiro, aposentado, CPF $\mathbf{n}^{\circ}$ 977.806.188-20, RG n ${ }^{\circ} 14.968 .224-4-\mathrm{SSP} / \mathrm{SP}$, casado pelo regime da comunhão 
Matrícula

212.901
Ficha

01 verso $1^{\circ}$ OFICLAL DE REGISTRO DE IMÓVEIS E ANEXOS SÃO JOSÉ DOS CAMPOS - SP

\section{LIVRO NÚMERO DOIS}

\section{REGISTRO GERAL}

\section{Imóve:}

universal de bens, antes da vigência da Lei Federal $n^{\circ} 6.515 / 77$, com DURVALINA MOREIRA DE ANDRADE, brasileira, doméstica, CPF $n^{\circ} 315.859 .998-81$, RG $n^{\circ}$ 37.275.478-8-SSP/SP, residentes e domiciliados na Rua Dois, $n^{\circ} 34$, Lote 03, Quadra C, Recanto dos Eucaliptos, São José dos Campos-SP. Protocolo n $520.569 \mathrm{em} 02 \mathrm{de}$ dezembro de 2013.

Eu, Viviane Alves Bordin hon dos Reis, Auxiliar digitei.

Eu, Simone Rezende Vieira Alves, Escrevente conferi o instrumento, o ato praticado e assino. 


\begin{tabular}{|l|l|}
\hline $\begin{array}{l}\text { Matricula } \\
200.855\end{array}$ & Ficha \\
01 \\
\hline
\end{tabular}

\section{LIVRONÚMERODOIS}

$1^{\circ}$ OFICIAL DE REGISTRO DE IMÓVEIS E ANEXOS SÃO JOSÉ DOS CAMPOS - SP

Em 1 de agosto de 2011.

\section{Imovel:}

JARDIM MESQUITA

REGISTRO GERAL

O loce de terreno sem benfeitorias, com a área de 203,65 metros quadrados, sob $n^{\circ}$ 01, da gradra A, situado com frente para a Rua 02, do loteamento denominado JARDIM MESQUITA, desta cidade, comarca e $1^{2}$ circunscrição imobiliária de São José dos Campons, com as seguintes medidas e confrontações: 5,84 metros de frente para a Rua $02 ; 3273$ metros pelo lado direito de quem da rua olha para o lote, com o lote $n^{\circ} 02 ; 31,96$ mettos pelo lado esquerdo com a propriedade de Érika Kajiwara Lourenço e Cristiane Kajiwara Lourenço (matricula 182.230) e 6,79 metros nos fundos com a propriedaçe de Érika Kajiwara Lourenço e Cristiane Kajiwara Lourenço (matrícula 182.230 ).

Cadastro Municipal: $\mathbf{7 4 . 0 5 0 0 . 0 1 0 2 . 0 0 0 0 .}$

Proprietários: VITAL SIMŌES LADEIRA, brasileiro, advogado, CPF $\mathrm{n}^{\circ}$ 145.548.608-68, RG $n^{\circ}$ 7.613.2-SSP/SP e sua mulher LÚCIA DOS SANTOS LADEIRA, brasileira, do lar, RG n 8.069665-X-SSP/SP, CPF $n^{\circ}$ 739.424.648-53, casados pelo regime da comunhão universal de bens, na vigência da Lei Federal $n^{\circ}$ $6.515 / 77$, conforme escritura de pacto antenupcial, registrada sob $\mathrm{n}^{\circ} 8988$, livro 3-Registro Auxiliar, deste Cartório, residentes e doiniciliados na Rua Pio XII, $n^{\circ} 19$, Jardim Esplanada, São José dos Campos-SP, referente a parte do imóvel objeto da matricula $n^{\circ} 130.987$, L.02 (averbaçăo $n^{\circ}$ 10) ERIKA KAJIWARA LOURENCO, brasileira, advogada, CPF $\mathrm{n}^{\circ}$ 201895.578-00, RG $\mathrm{n}^{\circ}$ 23.804.711-SSP/SP, divorciada residente e domiciliada na Rua José Raimundo da Silva, $n^{\circ}$ 282, Jardim das Colinas, São José dos Campos-SP e CRISTLANE KAJIWARA LOURENCO, brasileira, estudante, CPF n² 274.587.798-45, RG n ${ }^{\circ}$ 27.362.581-0-SSP/SP, solteira, maior, residente e domiciliada na Rua Jose Raimundo da Silva, $n^{\circ} 282$, Jardim das Colinas, São José dos Campos-SP; referente a parte do imóvel objeto da matricula $n^{\circ} 182.230$, L.02 (averbaçāo $n^{\circ} 04$ ).

Registro Anterior: Matricula $\mathrm{n}^{\circ} 199.145 \mathrm{em} 25 / 05 / 2011$, estando a Regularizaçáo Fundiária registrada sob $\mathrm{n}^{\circ} 05 \mathrm{em} 01 / 08 / 2011$, livro 2, deste Cartório. 


\begin{tabular}{|c|c|}
\hline $\begin{array}{c}\text { Matricula } \\
200.855\end{array}$ & Ficha \\
01 verso
\end{tabular}

$1^{\circ}$ OFICIAL DE REGISTRO DE IMÓVEIS E ANEXOS

SÃO JOSÉ DOS CAMPOS - SP

LIVRO NÚMERO DOIS

REGISTRO GERAL

Imóvel:

Protocolo $n^{\circ} 462.793 \mathrm{em} 16$ de junho de 2011.

$\mathrm{Eu}$, Ricardo Almada, Escrevente, digitei, conferi o instrumento, 0 ato praticado $\mathrm{e}$ assino.

Av. 01 - Em 01 de agosto de 2011.

Regularização Fundiária

Faço a presente para constar que o imóvel objeto desta matricula foi submetido a Regularização Fundiaria de Interesse Social, nos termos do artigo 53 e seguintes da Lei $n^{\circ} 11.977 / 2009$. Protocolo $n^{\circ} 462.793 \mathrm{em} 16$ de junho de 2011.

$\mathrm{Eu}$, the The The Almada, Escrevente digitei, conferi o instrumento, $o$ ato praticado e assino.

Av. 02 - Em 01 de agosto de 2011.

Transporte de Usufruto

Conforme averbaçăo $n^{\circ}$ 01, na matricula $\mathrm{n} 199.145$ em 25 de maio de 2011, consta que de acordo com registro $n^{\circ} 04$ na matrícula $n^{\circ} 130.987$, livro 2, deste Cartório, parte ideal do imóvel objeto desta matrícula pettencente a ERIKA KAJIWARA LOURENCYO E CRISTIANE KAJWARA LOURENCO encontra-se gravada com usufruto vitalício em favor de BERNARDINO LOURE NCO NETO, brasileiro, do comércio, RG $\mathrm{n}^{\circ}$ 5.209.561-SSP/SP e CPF/MF $\mathrm{n}^{\circ} 581.423 .398-20$ e sua mulher YOKO LOURENCO, japonesa, do lar, RNE $n^{\circ}$ W-094907-R-SE/DPMAF e CPF/MF $\mathrm{n}^{\circ}$ 159.570.218/06, casados pelo regime da conunhão de bens, anteriormente a vigência da Lei $n^{\circ} 6.515 / 77$, residentes e domiciliadios nesta cidade, na Rua José Raimundo da Silva, $n^{\circ} 282$, Jardim das Colinas. Protocolo $n^{\circ} 456.948$ em 15 de marco de 2011. Eu, Hise ftem Ricardo Almada, Escrevente digitei, conferi o
instrumento, o ato praticado e assino. 


\begin{tabular}{|c|c|}
\hline $\begin{array}{c}\text { Matrícula } \\
200.855\end{array}$ & 02 \\
\hline
\end{tabular}

$1^{\circ}$ OFICIAL DE REGISTRO DE IMÓVEIS E ANEXOS SÃO JOSÉ DOS CAMPOS - SP

LIVRO NÚMERO DOIS

REGISTRO GERAL

Imóve:

Av. 03. Em 01 de agosto de 2011.

Transporte de Cláusula

Conforme sverbação $n^{\circ} 02$, na matrícula $n^{\circ} 199.145$ em 25 de maio de 2011 , consta que de acordo com averbaçăo $n^{\circ} 05$ na matrícula $n^{\circ} 130.987$, livro 2 , deste Cartório, parte ideal do imóvel objeto desta matrícula pertencente a ERIKA KAJIWARA LOURENCO E CRESTIANE KAJIWARA LOURENÇO encontra-se gravada com cláusula de impenhor bilidade. Protocolo n $456.948 \mathrm{em} 15$ de março de 2011.

Eu, thind for

Ricardo Almada, Escrevente digitei, conferi o instrumento, $o$ ato praticado e assino.

R. 04 - Em 15 de fevereiro de 2012 .

Legitimação de Posse

Por Termo de Legitimação de Posse, contrato $\mathrm{n}^{\circ} 25565 / 11$ passado nesta cidade, em 09 de dezembro de 2011, a PREFEITURA MUNICIPAL DE SÃO JOSÉ DOS CAMPOS, CNPJ n ${ }^{\circ} 46.643 .466 / 0001-06$, Dos termos da Lei Federal 11.977/2009, concedeu título de legitimação de posse referente ao imóvel objeto desta matricula, para NEIDE APARECIDA DE ARAÚJO RIBEIRO, brasileira, do lar, CPF $\mathrm{n}^{\circ}$ 185.791.798-74, RG n 24.019.362-3-SP, casada pelo regime da comunhão parcial de bens, na vigência da Lei Federal $n^{\circ} 6.515 / 77$, com DDUARDO APARECIDO RIBEIRO, brasileiro, funcionário público, CPF $\mathrm{n}^{\circ}$ (19.687.518-82, RG $\mathrm{n}^{\circ}$ 18.222.071-0-SP, residentes e domiciliados no Lote $\mathrm{n}^{\circ}$ 0?. Quadra A, Jardim Mesquita, São José dos Campos-SP. Atual inscrição imobiliaria na Prefeitura Municipal local $n^{\circ} \mathbf{7 4 . 0 5 0 0 . 0 1 0 2 . 0 0 0 0}$. Protocolo $n^{\circ} 476.754$ em 13 de janeiro de 2012.

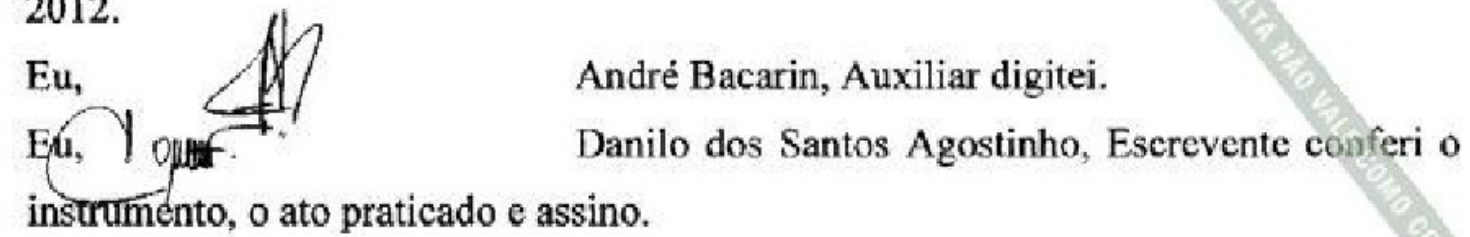




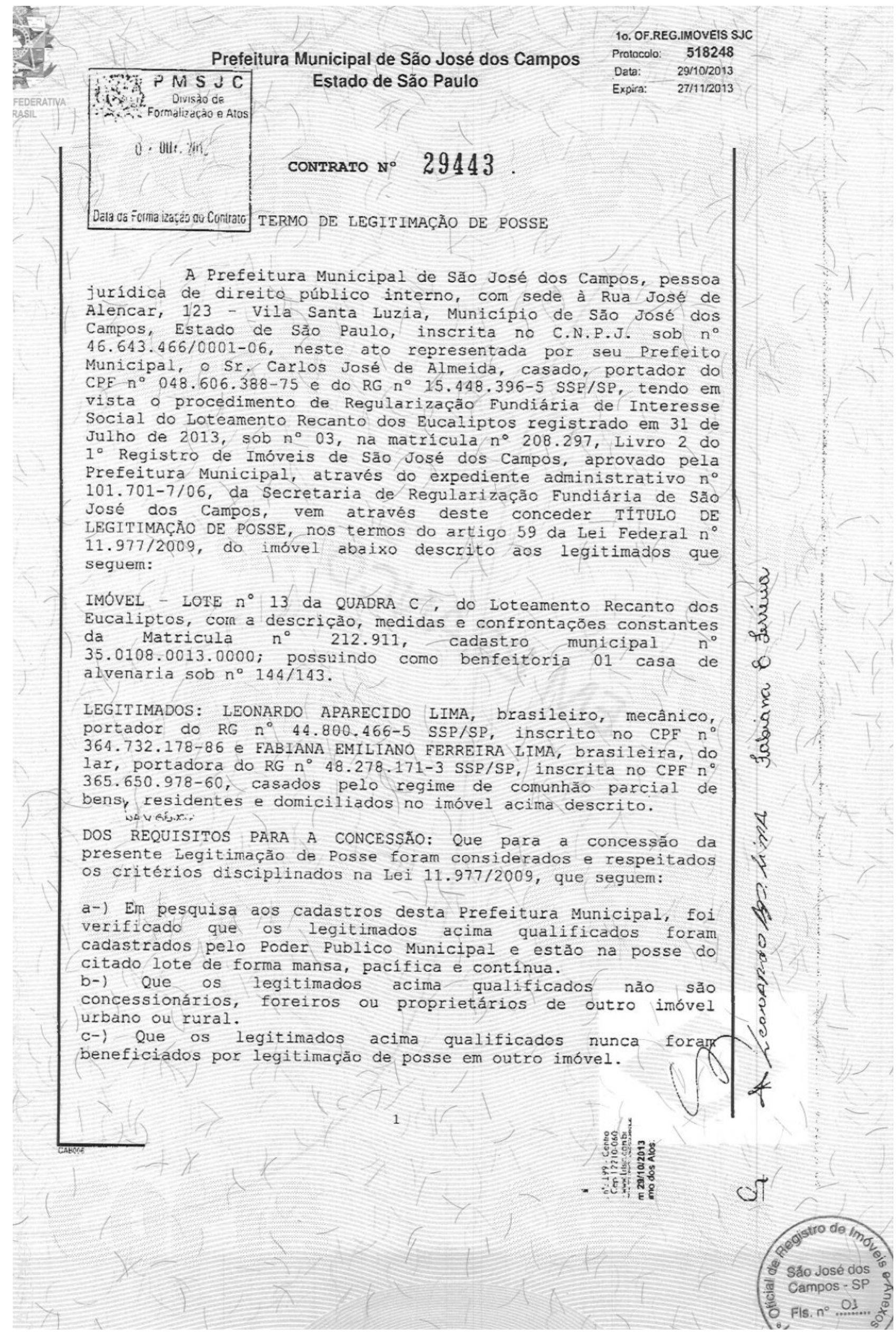




\section{Prefeitura Municipal de São José dos Campos Estado de São Paulo}

DA ACEITAÇÃO E CIÊNCIA DOS LEGITIMADOS:

a-) Os legitimados declaram que se enquadram nos requisitos previstos nos artigos 59 e 60 da Lei 11.977/2009, estando aptos a receber a presente legitimaçâo, a qual aceitam em todos os seus termos e condiçes.

b-) Ficam os legitimados cientes de que, de acordo com o disposto no artigo $60-A$ da lei $11.977 / 2009$, poderá o presente título de Legitimação de Posse ser extinto pelo Poder Público emitente quando for constatado que o beneficiário não esta na posse do imóvel e não houve registro da cessão de direitos.

c-) Ficam os legitimados cientes de que, após o registro do presente, poderão requerer a conversão da posse em propriedade, através da aquisição por usucapião, desde que cumpridos os requisitos do $\$ 1^{\circ}$ e $/ 3^{\circ}$ de artigo 60 , da Lei Federal $11.977 / 2009$.

Sāo José dos
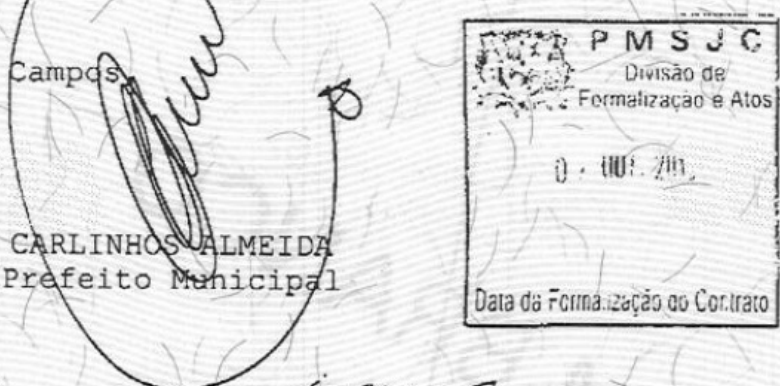
Prefe:
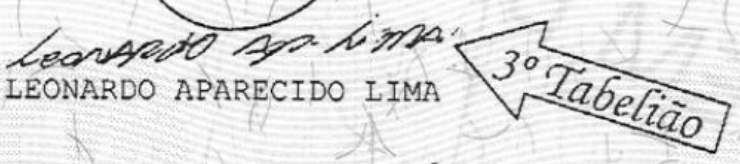

fabiana of ferviva<smiles>[C]1CCCC1</smiles>

fabiana of fervina $3^{\circ}$ Tabeliäo
FABIANA EMILIANO FERREIRA

TESTEMUNHAS :

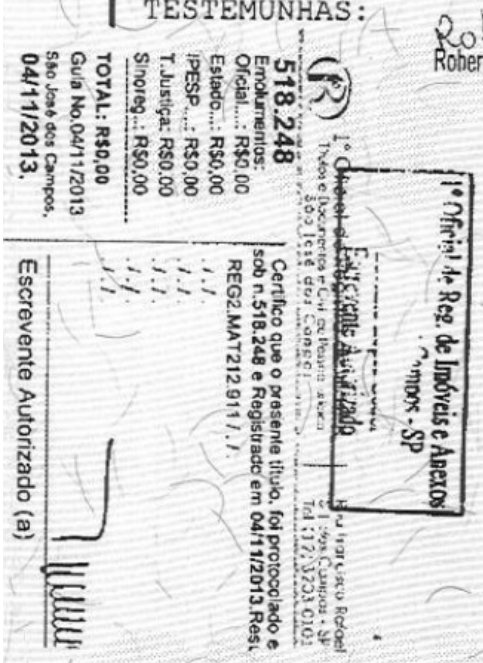
Robectiffrumes Corta Mrcondes Fourniol Rebellio Créie lia Divisăa DFAT AB-Si $=-155.84$

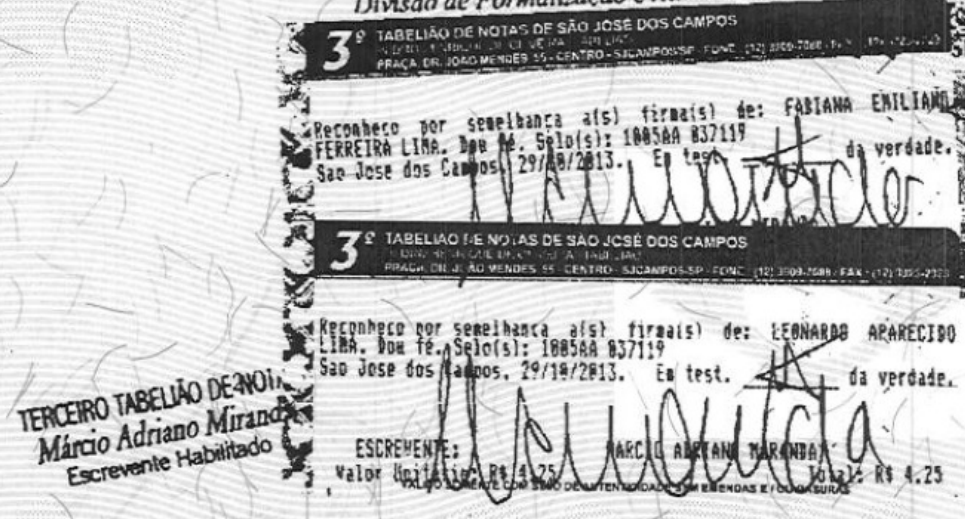




\section{$1^{\circ}$ OFICIAL DE REGISTRO DE IMÓVEIS, TITULOS E DOCUMENTOS E CIVIL DE PESSOA JURÍDICA ... São José dos Campos - SP}

\section{CERTIDÃO DE DOCUMENTO ARQUIVADO}

Certifico que a pres nte produção está conforme a documentação aprese tar' i para proceder a averbação de $n^{\circ} 02$, em 04 de novembro de 2013, na matricula $n^{\circ}$ 212.911, contendo $(j$ folhas, devidamente numeradas, as quais foram extraídas de acordo com o parágrafo $1^{\circ}$, do artigo 19 , da Lei $6.015 / 73$ (Lei dos Registros Públicos). NADA MAIS. Todo referido é verdade e dou fé. Sã J José dos Campos, 02 de janeiro de 2014.

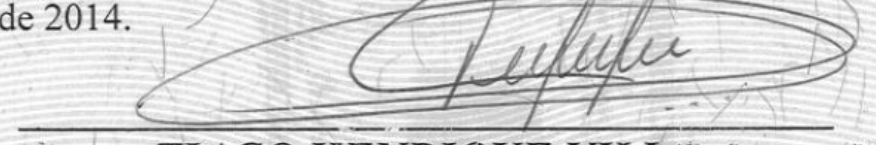

TIAGO HENRIQUE VILLA :

Escrevent. Autorizado

Oficial: R\$23,13 - Estado R\$6,57 - Carteira R\$4,87-Reg. Civil R\$1,22 - Trib. Justiça R\$i, 22 - Total R\$37,01

F tocolo $n^{0} 450.406$

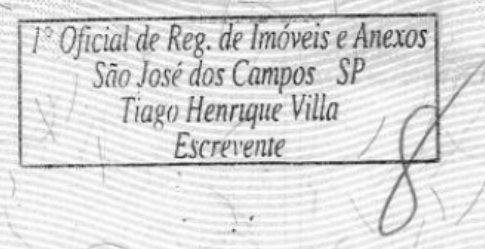




\section{CONCLUSÃO}

Chegamos, assim, em vista de todo o exposto, à nossa definição de posse, que acreditamos refletir as principais características que a descrevem em nosso ordenamento jurídico atual, lançando mão dos atributos que a distinguem e absorvendo o que foi mais aceito em todas as teorias que versaram sobre a posse: fenômeno multidimensional, que sempre se origina no fato transmudado de imediato em direito, direito este real, reconhecido pelo ordenamento, gerando importantes efeitos e consequências, notadamente a sua proteção independentemente de qualquer outro direito subjacente, consistindo no gérmen da propriedade, em razão de lhe ser a própria imagem. Do ponto de sua função social, apresenta também grande importância atual em nosso Direito e esta importância variará conforme o país onde o fenômeno possessório está sendo observado.

Independentemente da associação a alguma das teorias analisadas que buscam destacar a natureza jurídica da posse, a possibilidade de deter um bem para a satisfação das necessidades humanas é de tal importância que o legislador inicialmente defenderá e preservará aquele que se encontra nesta posição (de possuidor), para depois estabelecer o melhor direito de propriedade.

Isto não implicou, no entanto, que a posse alcançasse, tradicionalmente, a condição de direito real, pois tais direitos estão expressamente definidos nos termos do Código Civil e submetidos a registro por força do artigo 167 da Lei $n^{\circ}$ 6.015/73 (Lei de Registros Públicos) - sendo, portanto, a posse considerada usualmente por parte da doutrina como um direito pessoal, cujo exercício se manifesta - e verifica - de fato.

A única maneira, até então conhecida no Direito brasileiro, de convolar esta situação de fato (posse) em situação de direito (propriedade) consistia no ingresso da ação de usucapião, perante a jurisdição competente, objetivando este reconhecimento pela via jurisdicional, em conformidade aos ritos aplicáveis - e hoje existem várias as modalidades da usucapião no Direito brasileiro - modalidade de aquisição originária.

A Lei $n^{\circ} 11.977 / 2009$, tal como alterada pela Lei $n^{\circ} 12.424 / 2011$, confere uma nova formatação legal à posse, que merece atenção e exige a compreensão de uma nova visão de 
suas características e efeitos, até então inéditos em nosso ordenamento jurídico. Esta nova roupagem revoluciona o conceito de posse, as implicações e efeitos práticos deste instituto, nos termos dos indicados artigos 58 e 60, possibilitando a transformação da posse e propriedade, pela via meramente administrativa.

Assim, tal título de posse legitimada, conferido no âmbito da regularização fundiária, em caráter inédito, é passível de registro na matrícula do imóvel junto ao Cartório de Registro de Imóveis competente - sendo a primeira vez que a nossa legislação prevê a possibilidade de se levar a registro no fólio real uma situação de posse, pois, até então, apenas os direitos reais imobiliários seriam levados a registro na matrícula.

É o que determina o artigo 76 da citada Lei 11.977/2009, ao alterar a redação do artigo 167 da Lei de Registros Públicos, tornando o ato da legitimação da posse passível de registro, conforme o inciso I, $\mathrm{n}^{\circ} 41$ do aludido dispositivo.

Ademais, também foi a legitimação da posse incorporada ao Estatuto da Cidade, nos termos do artigo $4^{\circ}$, inciso $\mathrm{V}$, “ $\mathrm{u}$ ", bem como vem recebendo tratamento mais abrangente para facilitar e ampliar as hipóteses de seu registro, nas normas registrarias editadas pela Corregedoria de Justiça do Estado de São Paulo.

A experiência brasileira de conferir à posse contornos de direito real reproduz também o que aconteceu e acontece atualmente em países como Inglaterra, Portugal e Espanha, no tocante a possibilitar o registro da posse, de forma a se obter resultados sociais almejados de forma mais efetiva e célere.

A posse deixa de ser considerada apenas fato para ser concretizada em direito devidamente registrado na matrícula do imóvel. Impedir que seja atribuída a característica real à posse, apenas por apreço à tradição doutrinária, não pareceria posição razoável, e sim contrariar o novo tratamento legal.

A posse figurada como direito real ganha também maior autonomia em relação à propriedade, deixando para trás essa discussão, aumentando enormemente a sua importância social. Garantir-lhe a qualidade jurídica de direito real em muito ajudará a 
tornar ainda mais este instituto socialmente relevante, para minimizar as desigualdades sociais que há tanto tempo afligem nosso país, cumprindo sua função social.

Assim, com esta alteração legislativa de grande magnitude, a posse legitimada passa a ser entendida como direito real passível de registro na certidão da matrícula do imóvel junto ao Cartório de Registro de Imóveis, como, aliás, já entende e defende grande parte da doutrina, mesmo antes da edição da nova legislação.

Consideramos especialmente relevante o novo tratamento legal da posse em nosso país, representando a contribuição do Direito e de seus operadores para apresentação de soluções efetivas à regularização da moradia de milhões de pessoas, além de propriciar sua inserção na cidade formal, com todos benefícios que isso representa.

A posse registrada é, portanto, mais significativa juridicamente que o próprio direito real de compromisso de compra e venda, pois independe mesmo de decisão judicial (como na ação de adjudicação compulsória) para obtenção da propriedade.

A administração adequada do instituto da posse pelos operadores do Direito, com a nova e reforçada estrutura legal, em muito auxiliará na busca por uma sociedade mais equilibrada e justa. Todavia, tal como demonstrado pela experiência de outros países, também chegará o dia que a posse perderá importância entre nós. Esperamos, sinceramente, que este dia não esteja distante. 


\section{BIBLIOGRAFIA}

AlbuQuerque, Ana Rita Vieira. Da Função Social da Posse e sua consequiência frente à situação proprietária. $1^{\mathrm{a}}$ ed. $2^{\mathrm{a}}$ tir. Rio de Janeiro: Lúmen Júris, 2002.

ALMEIDA, Paulo Guilherme de. Direito Agrário - a propriedade imobiliária rural. São Paulo: Ed. Ltr, 1980.

Paulo Guilherme de. Temas de Direito Agrário. São Paulo: Ed. Ltr, 1988.

ALVES, José Carlos Moreira Alves. Direito Romano. $6^{\mathrm{a}}$ ed. rev. acres. Rio de Janeiro: Forense, 1987, v. 1.

José Carlos Moreira Alves. Posse - Evolução Histórica. Rio de Janeiro: Forense, 1985, v. 1.

José Carlos Moreira Alves. Posse - Estudo Dogmático. Rio de Janeiro: Forense, 1985, v. 2.

José Carlos Moreira. A Detenção no Direito Civil Brasileiro (conceito e casos). In POSSE E PROPRIEDADE Doutrina e Jurisprudência. Yussef Said Cahali (coord.) São Paulo: Saraiva, 1973.

AQUINO, Álvaro Antônio Sagulo Borges de Aquino. A posse e seus efeitos. $2^{\mathrm{a}}$ ed. rev. atual. amp. Rio de Janeiro: Lúmen Juris, 2008.

ASCENSÃO, José de Oliveira. Direito Civil - Reais. $5^{\text {a }}$ ed. reimpressão. Lisboa: Coimbra Editora, 2000.

ASURMENDI, Camino Sanciñena. La Usucapión Inmobiliaria. Navarra, Espanha: Thonson Reuters, 2009. 
BALBINO FILHO, Nicolau. Registro de Imóveis - Doutrina, Prática e Jurisprudência. $16^{\mathrm{a}}$ ed. rev. atual. São Paulo: Saraiva, 2012.

BARBOSA, Ruy. Posse de direitos. São Paulo: Saraiva, 1986.

BARROS, Washington; MALUF, Carlos Alberto Dabus. Curso de Direito Civil - Direito das coisas. $42^{\mathrm{a}}$ ed., São Paulo: Saraiva, 2012.

BARROS, Washington. Curso de Direito Civil - Direito das coisas. Atualizada por Carlos Alberto Dabus Maluf. $8^{\text {a }}$ ed. São Paulo: Saraiva, 2007.

BARROS, Washington. Curso de Direito Civil - Direito das coisas. $5^{\text {a }}$ ed. São Paulo: Saraiva, 1963.

BERGEL, Jean-Louis; BRUSCHI, Marc; CIMAMONTI, Sylvie. Traité de Droit Civil Les biens. $2^{\mathrm{a}}$ ed. Paris: Lextenso Éditions, 2010.

BESSONE, Darcy. Da posse. São Paulo: Saraiva, 1996.

BITTAR, Carlos Alberto. Direitos Reais. $2^{\mathrm{a}}$ ed. rev. atual. por Carlos Alberto Bittar Filho e Márcia Sguizzardi Bittar. Rio de Janeiro: Forense, 2011.

BIONDI, Biondo, Istituzioni di Diritto Romano. $4^{\text {a }}$ ed. rev. acres. Milão: Casa Editrice, 1907.

Biondo. Los Bienes. Tradutor Antonio de la Esperanza Martínez-Radío. Barcelona: Bosch, 1961.

BONFANTE, Pietro. Istituzioni di Diritto Romano. $4^{\text {a }}$ ed. amp. atual. Milão: Giuffrè Editore, 1972.

CAHALI, Yussef Said. (coordenação) Posse e Propriedade. Doutrina e Jurisprudência. São Paulo: Saraiva, 1987. 
CARNELUTTI, Francesco. Teoria Geral do Direito. Trad. A. Rodrigues Queiró e Artur Anselmo de Castro. São Paulo: Âmbito Cultural Edições, 2006.

CASSATTARI, Christiano. (coordenação) 10 anos de vigência do Código Civil Brasileiro de 2002. Estudos em homenagem ao Professor Carlos Alberto Dabus Maluf. Orientação Rui Geraldo Camargo Viana. São Paulo: Saravia, 2013.

CHAMOUN, Ebert. Instituições de Direito Romano. $4^{\mathrm{a}}$ ed. rev. aum., Rio de Janeiro: Companhia Editora Forense, 1962.

COELHO, José Fernando Lutz. Contratos Agrários. Uma visão neo-agrarista. Curitiba: Juruá, 2006.

CORDEIRO, António Menezes. A Posse: perspectivas dogmáticas actuais. $3^{\mathrm{a}}$ ed. atual. Lisboa: Almedina, 2000.

CYSNEIROS, Vicente Cavalcanti. O estrangeiro e a propriedade rural. Porto Alegre: Sergio Fabris Editor, 1985.

DÍEZ-PICAZO, Luis. Fundamentos del Derecho Civil Patrimonial III - las relaciones jurídico-reales. $5^{\mathrm{a}}$ ed. Pamplona: Thonson Civitas, 2008.

DINIZ, Maria Helena Diniz. Curso de Direito Civil Brasileiro - Direito das Coisas. 22 ${ }^{\mathrm{a}}$ ed. rev. atual., São Paulo: Saraiva, 2007, v. 4.

DUBERTRET, Matthieu. Negociabilité et possession. Paris: Éditions Panthéon-Assas, 2010.

FACHIN, Luiz Edson. A função social da posse e a propriedade contemporânea (uma perspectiva da usucapião imobiliária rural). Paraná: Sergio Antonio Fabris Editor, 1988. 
FARIAS, Cristiano Chaves de Farias; ROSENVALD, Nelson. Direitos reais. $4^{\mathrm{a}}$ ed. Rio de Janeiro: Lumen Juris, 2007.

Curso de Direito Civil - reais. $9^{a}$ ed. rev. amp. atual. Rio de Janeiro: JusPodivm, 2013.

FIGUEIRA JR., Joel Dias. Posse e ações possessórias - Fundamentos da Posse. Curitiba: Juruá Editora, 1994, v. 1.

FRANÇA, R. Limongi. A Posse no Código Civil (noções fundamentais). São Paulo: José Bushatsky Editor, 1964.

R. Limongi. Manual Prático das desapropriações. $2^{\text {a }}$ ed. atual. e aum. São Paulo: Saraiva, 1978.

FULGÊNCIO, Tito. Da posse e das ações possessórias. Atualizador José de Aguiar Dias. Rio de Janeiro: Forense, 1984, v. 1.

GIANCOLI, Brunno Pandori. Direito Civil. São Paulo: Revista dos Tribunais, 2012, v. 4.

GIL, António Hernández. La función social de la posesión (ensayo de teorización sociológico-jurídica). Madrid: Alianza Editorial, 1969.

GIRARD, Paul Frédéric. Manuel Élémentaire de Droit Romain. $4^{\mathrm{a}}$ ed. Paris: Arthur Rousseau Éditeur, 1906.

GODOY, Claudio Luiz Bueno de. Função Social do Contrato. $3^{\mathrm{a}}$ ed. São Paulo: Saraiva, 2009.

GOMES, Orlando. Direitos Reais. Atualizador Luis Edson Fachin. $21^{\mathrm{a}}$ ed. rev e atual. Rio de Janeiro: Fores, 2012. 
Orlando. Direitos Reais. Atualizador Humberto Theodoro Júnior. $12^{\mathrm{a}}$ ed. Rio de Janeiro: Fores, 1996.

GONÇAVES, Carlos Roberto. Direito Civil Brasileiro - Direito das coisas. $6^{\text {a }}$ ed. São Paulo: Saraiva, 2011, v. 5.

GONÇALVES, Marcus Vinicius Rios. Dos Vícios da Posse. $3^{\text {a }}$ ed. São Paulo: Ed. Juarez de Oliveira, 2003.

GOYOS JR., Durval de Noronha; SOUZA, Adriano Boni de; BRATZ, Eduardo. Direito Agrário Brasileiro e o Agronegócio Internacional. São Paulo: Observador Legal, 2007.

GRAY, Kevin; GRAY, Susan Francis. Elements of Land Law. $5^{\text {a }}$ ed. Great Britain: Oxford University Press, 2009.

HIRONAKA, Giselda Maria Fernandes Novaes. O extrativismo no direito agrário brasileiro. Tese apresentada à Faculdade de Direito da Universidade de São Paulo, visando a obtenção do grau de Doutor em Direito Agrário, sob a orientação do Porfessor Doutor Silvio Rodrigues, dezembro de 1981.

IHERING, Rudolf von. Études Complémentaires de L'Esprit du Droit Romain. Tome III Du Rôle de la Volonté dans la Possession. Trad. O. de Meulenaere, Paris: LibrairieMarescq et Cie, 1891.

Rudolf von. Fundamentos dos Interditos Possessórios. Trad. Adherbal de Carvalho. Campinas: Edipro, 2007.

Rudolf Von. L'esprit du droit romain dans les diverses phases de son développement. Tradutor O. de Meulenaere. Paris: Marescq, 1880, v. 4.

Rudolf von. Ouevres Choisies - Tome II Possession. Théorie simplifiée et mise à la portée de tout le monde (1890). Trad. O. de Meulenaere, Paris: LibrairieMarescq et Cie, 1893. 
Rudolf Von. Teoria Simplificada da Posse. Tradutor Ivo de Paula. São Paulo: Pillares, 2005.

TREVELIM, Ivandro Ristum. A Alienação Fiduciária em Garantia e sua aplicação no mercado de financiamento imobiliário. Dissertação de mestrado apresentada e aprovada na Faculdade de Direito da Universidade de São Paulo, maio de 2008.

KRIEF-SEMITKO, Catherine. La valeur en droit civil français - essai sur les bien, la proprieté et la possession. Paris: L’Harmattan, 2009.

LIMA, Getúlio Targino. A posse agrária sobre bem imóvel. São Paulo: Saravia, 1992.

LINS, Edmundo Pereira. Estudos Jurídicos na Cátedra e na Judicatura. Ensaio sobre a Posse (direito romano e civil). Rio de Janeiro: Ed. Coelho Branco, 1935.

LISBOA, Roberto Senise. Manual de Direito Civil - direitos reais e direitos intelectuais. $5^{\mathrm{a}}$ ed. aum. atual. São Paulo: Saraiva, 2011.

LOPES, Miguel Maria de Serpa. Curso de Direito Civil - Direito das coisas. $3^{\mathrm{a}}$ ed. São Paulo: Freitas Bastos, 1964, v. VI.

LOUREIRO, Luiz Guilherme. Registros Públicos - Teoria e Prática. 3 ed. rev. atual., ampl. São Paulo, Método, 2012.

MALUF, Carlos Alberto Dabus. Limitações ao Direito de Propriedade. $2^{\text {a }}$ ed. rev. atual. e amp. São Paulo: Revista dos Tribunais, 2005.

Carlos Alberto Dabus; MALUF; Adriana Caldas do Rego Freitas Dabus. Comentários ao Estatuto da Cidade (Lei n⿳ 10.257/2001). São Paulo: Atlas, 2011.

MARKY, Thomas. Curso Elementar de Direito Romano. $7^{\mathrm{a}}$ ed. São Paulo: Saraiva, 1994. 
MELO, Marco Aurélio Bezerra de. Direito das Coisas. Rio de Janeiro: Limen Júris, 1999.

MCFARLANE, Ben; HOPKINS, Nicholas; NIELD, Sarah. Land Law - text, cases, and materials. Great Britain: Oxford University Press, 2009.

NALINI, José Renato; LEVY, Wilson (coord.). Regularização Fundiária. $2^{\mathrm{a}}$ ed. rev. atual. amp. Rio de Janeirio: Forense, 2013.

OPTIZ, Oswaldo; OPTIZ, Silvia C. B. Curso completo de direito agrário. $5^{\mathrm{a}}$ ed. rev. atual. São Paulo: Saraiva, 2011.

PENCO, Angel Acedo. Derechos Reales y derecho inmobiliario registral. Madrid: Editorial Dykinson S.L., 2012.

PEREIRA, Caio Mario da Silva. Instituições de Direito Civil - direitos reais. $21^{\mathrm{a}}$ ed. rev. e atual. por Carlos Edson do Rêgo Monteiro Filho. Rio de Janeiro: Forense, 2013, v. IV.

PEREIRA, Lafayette Rodrigues. Direito das Coisas. Adaptação ao Código Civil por José Bonifácio de Andrada e Silva. $6^{\text {a }}$ ed. São Paulo: Freitas Bastos, 1956.

PEROZZI, Silvio. Istituzioni di Diritto Romano. $2^{\mathrm{a}}$ ed. rev. amp. Roma: Athenaeum, 1949, v. 1.

POLLOCK, Frederick; WRIGHT, Robert Samuel. An essay on possession in the common law. Londres: Claredon Press, 1888.

PUGLIESE, Roberto J. Summa da Posse - direito, ação e legislação. São Paulo: Leud, 1992, v. 1.

pinas: Bookseller, 1999. v. II.

RÁO, Vicente. Posse de Direitos Pessoais - Segundo o Código Civil Brasileiro. São Paulo. 
RAVAIL, Pierre-Julien. De l'object de la possession - Essai sur le droit romain, l'ancien droit français et le droit actuel. Paris: Arthur Rousseau, 1899.

REZENDE, Astolpho. A posse e sua proteção. Atualizador Jose Carlos Barbosa Moreira. $2^{\mathrm{a}}$ ed. São Paulo: Lejus, 2000.

RIBAS, Antonio Joaquim. Da posse e das ações possessórias. ed. anotada. São Paulo: Miguel Mellilo, 1901.

RIOS, Arthur. Regularização Fundiária Urbana. Curitiba: Juruá, 2012.

ROCHA, M. A. Coelho da. Instituições de Direito Civil - tomo II. São Paulo: Saraiva, 1984, v. 5 .

ROCHA, Olavo Acyr de Lima. A desapropriação no direito agrário. São Paulo: Editora Atlas, 1992.

RODRIGUES, Manuel. A posse - Estudo de Direito Civil Português. $2^{\mathrm{a}}$ ed. rev. e atual. Coimbra: 1940.

RODRIGUES, Silvio. Direito civil - Direito das Coisas. $28^{\mathrm{a}}$ ed. rev. atual, São Paulo: Saraiva, 2003, v. 5.

ROSA, Pedro Henrique de Miranda. Fontes Históricas da Teoria da Posse no Direito Civil Brasileiro. Rio de Janeiro: Itambé, 1970.

Direito Civil - Direito das coisas; introdução, posse; da propriedade; dos direitos reais sobre coisas alheias. Rio de Janeiro: Renovar, 2005.

RUGGIERO, Roberto de. Instituições de Direito Civil. Tradutor Paolo Capitanio da $6^{\text {a }}$ ed. italiana. Atualizado por Paulo Roberto Bernasse. $1^{\mathrm{a}}$ ed. Campinas: Bookseller, 1999. 
SALEILLES, Raymond. De la possession des meuble. Paris: F. Pichon et Durand-Auzias Administrateurs: 1907.

SAVIGNY. Frédéric Charles de. Traité de la possession en droit romain. Tradução do alemão para o francês por Genri Staedtler, $7^{\mathrm{a}}$ ed. Paris: Auguste Durand LibraireÉditeruys, 1866.

Treatise on Possession: the jus possessionis of the civil law. Tradução de Sir Erskine Perry. Londres: Law Booklseller and Publisher, 1848.

SCAFF, Fernando Campos. Teoria Geral do Estabelecimento Agrário. São Paulo: Revista dos Tribunais, 2001.

Fernando Campos. Aspectos Fundamentais da Empresa Agrária. São Paulo: Malheiros, 1997. , Fernando Campos. Direito Agrário. Origens, Evolução e Biotecnologia. São Paulo: Atlas, 2012.

SILVA, Paula Costa. Posse ou Posses? 2a ed. Lisboa: Coimbra Editora, 2005.

SODRÉ, Eurico. A Desapropriação por Necessidade ou Utilidade Pública. $2^{\mathrm{a}}$ ed. São Paulo: Saraiva, 1945.

SOTERO. Fernando Pereira. Direito Agrário e Reforma Agrária. São Paulo: Livraria Legislação Brasileira, 1968.

SOUSA LIMA, Otto. Negócio fiduciário. São Paulo: Revista dos Tribunais, 1962.

TARTIÈRE, Gabriel de Reina. Principios Registrales - Estúdio Del derecho registral inmobiliario argentino. Buenos Aires: Editorial Heliasta S.R.L., 2009. 
TARTUCE, Flávio; SIMÃO, José Fernando. Direito Civil - Direito das Coisas. $4^{\mathrm{a}}$ ed. rev. atual. São Paulo: Método, v. 4.

TEPEDINO, Gustavo José Mendes. Temas de direito civil. Contornos Constitucionais da Propriedade Privada. $3^{\mathrm{a}}$ ed. rev. e atual. Rio de Janeiro: Renovar, 2004.

Gustavo; SCHEREIBER, Anderson. Questões Agrárias. Julgados comentados e pareceres. O papel do Poder Judiciário na efetivação da função social da propriedade. São Paulo: Método, 2002.

Gustavo. Comentários ao Código Civil, Direito das Coisas. Coordenador Antônio Junqueira de Azevedo. São Paulo: Saraiva, 2011, v. 14.

TERRÉ François; SIMLER, Philippe. Droit Civil - Les biens. $8^{\mathrm{a}}$ ed. Paris: Éditions Dalloz, 2010.

THEODORO JÚNIOR, Humberto. Posse e Usucapião. Rio de Janeiro: Aide Editora, 1991.

Humberto. Posse e Propriedade. São Paulo: Leud, 1985.

TOBEÑAS, Jose Castan. Derecho Civil Español, Comun y Foral. $14^{\mathrm{a}}$ ed. atual. por Gabriel Garcia Cantero. Madrid: Reus S.A., 1992, v. 1.

TORRES, Marcos Alcino de Azevedo. A propriedade e a posse - um confronto em torno da Função Social. $2^{\text {a }}$ ed., Rio de Janeiro: Lúmen Júris, 2008.

VALDECASAS, Guillermo G. La Posesión. Granada: Editorial Comares, 2006.

VENOSA, Silvio de Salvo Venosa. Direitos Reais. São Paulo: Atlas, 2013, v. 5.

Sílvio de Salvo. Código Civil Comentado - Direito das Coisas. AZEVEDO, Alvaro Villaça (coordenador). São Paulo: Atlas, 2003, v. XII. 
VIANA, Rui Geraldo Camargo. Comentários sobre o Proejto do Código Civil Brasileiro, Série Cadernos do Conselho da Justiça Federal - Direito das Coisas, Vol. 20, Brasília, 2002.

VIEIRA, José Alberto C. Direitos Reais. Lisboa: Coimbra Editora, 2008.

WHITAKER, F. Terras. Divisões e Demarcações. 5ª ed. São Paulo, 1926.

WOLFF, Martin. Tratado de Derecho Civil, Tomo Terceiro - Derecho de Cosas Tomo Terceiro. Por Ludwig Enneccerus, Theodor Kipp e Martin Wolff. Tradutores Blas Pérez González e José Alguer. Barcelona: Bosch Casa Editorial, 1936, v. 1.

WONNACOTT, Mark. Possession of land. Londres: Cambridge University Press, 2006.

Periódicos, Revistas e Artigos

BARROS, Wellington Pacheco. A propriedade agrária e seu novo conceito jurídicoconstitucional. Revista da Ajuris, nº 46, julho 1989.

COELHO, Antônio Augusto de Souza. A proteção possessória do imóvel rural e a posse agrária. Jus Navigandi, Teresina, ano 16, $\mathrm{n}^{\circ}$. 2924, 4.7.2011. Disponível em: <http://jus.com.br/artigos/19467>. Acesso em: 16 dez. 2013.

COMPARATO, Fábio Konder. Direitos e deveres fundamentais em matéria de propriedade. Revista da Fundação Escola Superior do Ministério Público do Distrito Federal e Territórios. Ano 5- no 10 - jul/dez de 1997.

FACHIN, Luiz Edson. Revista da EMERJ - Escola da Magistratura do Estado do Rio de Janeiro. Ed. especial. Parte II, julho 2002 a abril 2003. 
HIRONAKA, Giselda Maria Fernandes Novaes. O extrativismo como atividade agrária. Jus Navigandi, Teresina, ano 5, $\mathrm{n}^{\mathrm{o}}$ 42, 1.6.2000. Disponível em: <http://jus.com.br/artigos/1667>. Acesso em: 14 de dezembro de 2013.

; CHINELATO, Silmara Juny de Abreu. Propriedade e Posse: uma releitura dos ancestrais institutos. Revista da Faculdade de Direito da Universidade de São Paulo. v. 98, 2003.

KOJRANSKI, Kojranski. As Favelas: O Desafio de sua Regularização Jurídica. Revista do Instituto dos Advogados de São Paulo, vol. 14, julho, 2004.

LIMA, Getulio Targino. Direito Agrário: novo enfoque de sua relação fundamental (homem, terra, produção) e releitura de alguns de seus princípios. Revista de Direito - Procuradoria Geral do Estado de Goiás - PGE-GO. Disponível em: < http://www.pge.go.gov.br/revista/index.php/revistapge/article/view/103 >. Acesso em: 16.12.2013.

MATTOS NETO, Antonio Jose. A Jurisprudência de posse no direito agrário brasileiro - perspectivas críticas. Revista de Direito Civil Imobiliário, Agrário e Empresarial, n. 10, janeiro/março de 1986, v. 10.

Institutos básicos do direito agrário à luz da Constituição de 1988. Revista de Direito Civil Imobiliário, Agrário e Empresarial, no 55, janeiro/março de 1991, v. 15 .

NOBRE JUNIOR, Edilson Pereira. A Posse e a Propriedade no Novo Código Civil. Exposição realizada durante seminário “Grandes temas jurídicos: o novo código civil”, em 15.7.2002.

REALE, Miguel. Visão Geral do Projeto de Código Civil. Disponível em: <http://www.miguelreale.com.br/artigos/vgpcc.htm > acesso em 16.12.2012. 
REALE, Miguel. Anteprojeto do Código Civil, Revista de Informação Legislativa. Periódico trimestral editado pela Subsecretaria de Edições Técnicas do Senado Federal, julho a setembro de 1972.

TEPEDINO, Gustavo José Mendes. Os Direitos Reais no Novo Código Civil. Revista da EMERJ - Escola da Magistratura do Estado do Rio de Janeiro. Ed. especial. Parte II, julho 2002 a abril 2003 (texto elaborado a partir da transcrição fonográfica de palestra proferida na Emerj em 8.11.2002).

, Gustavo José Mendes. Temas de direito civil. Contornos Constitucionais da Propriedade Privada. $3^{\mathrm{a}}$ ed. rev. e atual. Rio de Janeiro: Renovar, 2004.

Gustavo José Mendes. Revista da Faculdade de Direito de Campos. A garantia da propriedade no direito brasileiro. Ano VI, nº 6, junho de 2004.

VIANA, Rui Geraldo Camargo. A função social da propriedade. Ministério Publico do Estado do Pará - Centro de Apoio Operacional Consitucional. Disponível em: $<$ https://www2.mp.pa.gov.br/sistemas/gcsubsites/upload/39/afuncaosocialdapropriedade.p df $>$ acesso em 6.12.2013.

ZAVASCKI, Teori Albino. A tutela da posse na Constituição e no Novo Código Civil. Revista Brasileira da Direito Constitucional, no 5, jan./jun. 2005.

\section{Legislação}

BRASIL, Ministério da Justiça. Anteprojeto de Código Civil. Comissão Elaboradora e Revisora: Miguel Reale, José Carlos Moreira Alves, Agostinho de Arruda Alvim, Sylvio Marcondes, Ebert Vianna Chamoun, Clovis do Couto e Silva, Torquato Castro. 1972.

BRASIL. Ministério das Cidades. Regularização Fundiária Urbana: como aplicar a Lei Federal n. 11.977/2009, Secretaria Nacional de Habitação e Secretaria Nacional de Programas Urbanos. Brasília, 2010. 
LEI N' 11.977, DE 7 DE JULHO DE 2009:

http://www.planalto.gov.br/ccivil_03/_ato2007-2010/2009/lei/111977.htm

LEI N $N^{\circ}$ 12.424, DE 16 DE JUNHO DE 2011:

http://www.planalto.gov.br/ccivil_03/_ato2011-2014/2011/Lei/L12424.htm

LEI N ${ }^{0}$ 10.257, DE 10 DE JULHO DE 2001:

http://www.planalto.gov.br/ccivil_03/leis/leis_2001/110257.htm

LEI No 6.015, DE 31 DE DEZEMBRO DE 1973:

http://www.planalto.gov.br/ccivil_03/leis/16015.htm

LEI $N^{0}$ 10.406, DE 10 DE JANEIRO DE 2002:

http://www.planalto.gov.br/ccivil_03/leis/2002/110406.htm 